DANIELLA VILELA LIMA

\title{
ANÁLISE DA DIVERSIDADE, ABUNDÂNCIA E ESTRUTURA FUNCIONAL DA COMUNIDADE MICROBIANA DE TRÊS MANGUEZAIS DO ESTADO DE SÃO PAULO, BRASIL
}

Tese apresentada ao Programa de PósGraduação em Microbiologia do Instituto de Ciências Biomédicas da Universidade de São Paulo, para obtenção do título de Doutor em Ciências. 
DANIELLA VILELA LIMA

\section{ANÁLISE DA DIVERSIDADE, ABUNDÂNCIA E ESTRUTURA \\ FUNCIONAL DA COMUNIDADE MICROBIANA DE TRÊS \\ MANGUEZAIS DO ESTADO DE SÃO PAULO, BRASIL}

Tese apresentada ao Programa de PósGraduação em Microbiologia do Instituto de Ciências Biomédicas da Universidade de São Paulo, para obtenção do título de Doutor em Ciências.

Área de concentração: Microbiologia

Orientadora: Dra. Vivian Helena Pellizari

Versão corrigida. Versão original eletrônica encontra-se disponível tanto na Biblioteca do ICB quanto na Biblioteca de Teses e Dissertações da USP (BDTD). 
DADOS DE CATALOGAÇAO NA PUBLICAÇÃO (CIP)

Serviço de Biblioteca e Informação Biomédica do

Instituto de Ciências Biomédicas da Universidade de São Paulo

(C) Reprodução parcial

Lima, Daniella Vilela.

Análise da diversidade, abundância e estrutura funcional da comunidade microbiana de três manguezais do estado de São Paulo, Brasil / Daniella Vilela Lima. - São Paulo, 2012.

Orientadora: Profa. Dra. Vivian Helena Pellizari.

Tese (Doutorado) - Universidade de São Paulo. Instituto de Ciências Biomédicas. Departamento de Microbiologia. Área de concentração: Microbiologia. Linha de pesquisa: Diversidade microbiana.

Versão do título para o inglês: Analysis of diversity, abundance and functional structure of microbial community in three mangroves from São Paulo State, Brazil.

1. Ecossistema de mangue 2. Microbiologia ambiental 3. Biodiversidade 4. Biologia molecular 5. Filogenia 6. Hidrocarbonetos I. Pellizari, Profa. Dra. Vivian Helena II. Universidade de São Paulo. Instituto de Ciências Biomédicas. Programa de Pós-Graduação em Microbiologia II. Título 
Candidato(a):

Título da Tese:

Orientador:
Daniella Vilela Lima.

Análise da diversidade, abundância e estrutura funcional da comunidade microbiana de três manguezais do estado de São Paulo, Brasil.

Profa. Dra. Vivian Helena Pellizari.

A Comissão Julgadora dos trabalhos de Defesa da Tese de Doutorado, em sessão pública realizada a considerou

\section{（） Aprovado (a) （） Reprovado (a)}

\begin{tabular}{|c|c|}
\hline \multirow[t]{3}{*}{ Examinador(a) } & 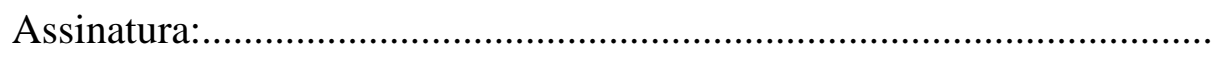 \\
\hline & Nome:........................................... \\
\hline & 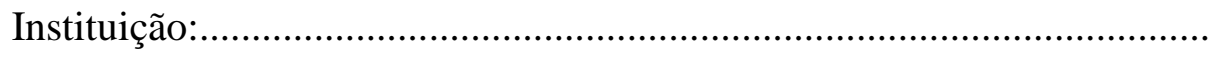 \\
\hline \multirow[t]{3}{*}{ Examinador(a) } & Assinatura: \\
\hline & 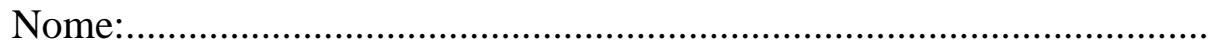 \\
\hline & 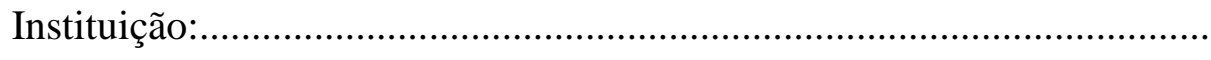 \\
\hline \multirow[t]{3}{*}{ Examinador(a) } & 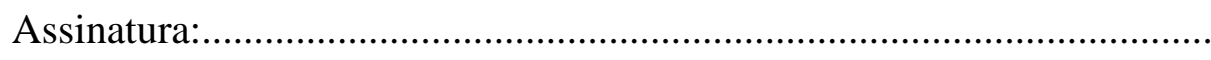 \\
\hline & Nome: \\
\hline & 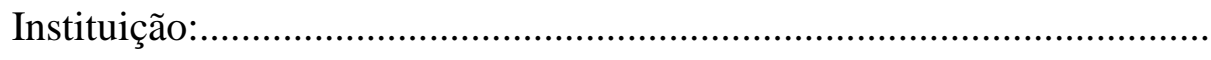 \\
\hline \multirow[t]{3}{*}{ Examinador(a) } & 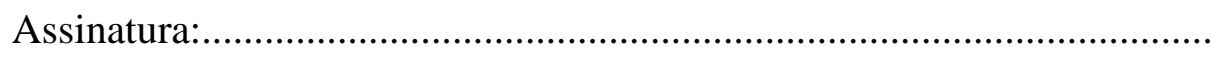 \\
\hline & 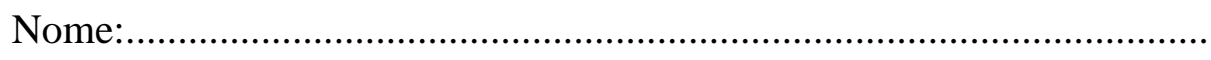 \\
\hline & 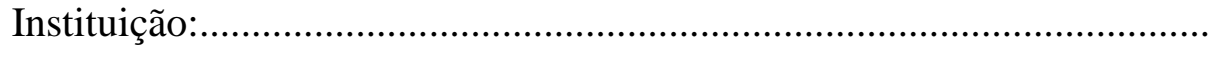 \\
\hline \multirow[t]{3}{*}{ Presidente } & Assinatura: \\
\hline & Nome: \\
\hline & 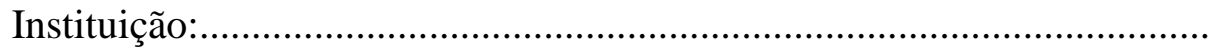 \\
\hline
\end{tabular}




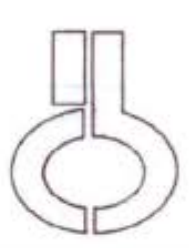

UNIVERSIDADE DE SÃO PAULO INSTITUTO DE CIÊNCIAS BIOMÉDICAS

Cidade Universitaria "Armando de Salles Oliveira"

Av. Prof. Lineu Prestes, 2415 - CEP. 05508-000 Sao Paulo, SP - Brasil

Telefone :(55) (11) 3091-7733 - telefax : (55) (11) $3091-7438$

e-mail: cup a tch usp br

Comissão de Ética em Pesquisa

\section{CERTIFICADO DE ISENÇÃO}

Certificamos que o Protocolo CEP-ICB N ${ }^{\circ} 227 / 07$, referente ao projeto intitulado: "Abundância e diversidade de genes catabólicos (alk e $A R H D$ ) e análise da estrutura da comunidade procarionte de três regiōes de mangue do Estado de São Paulo" sob a responsabilidade de Daniella Vilela Lima, foi analisado na presente data pela CEEA - COMISSÃO DE ÉTICA EM EXPERIMENTAÇÃO ANIMAL e pela CEPSH - COMISSÃO DE ÉTICA EM PESQUiSA COM SERES hUMANOS, tendo sido deliberado que o referido projeto não envolve manipulação animal ou humana que justifique uma aprovação quanto aos principios éticos exigidos por ambas as Comissões.

São Paulo, 31 de agosto de 2007.

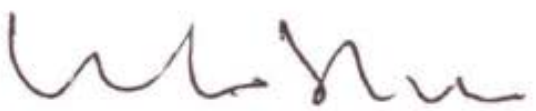

PROF. DR. WOTHAN TAVARES DE LiMA Coordenador da CEEA - ICB/USP

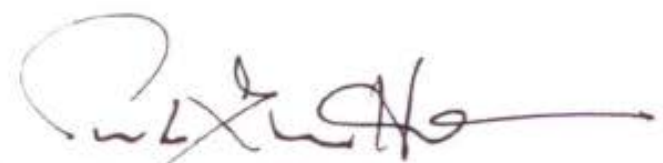

Prof. DR. PAOLO M.A ZanOTTO Vice-Coordenador da CEPsh - ICB/USP 
Aos meus pais $\mathcal{N}$ ilma e Guaraci pela vida concedida.

A minha irmã Alessandra e meus sobrinhos Lavinia e

Matheus por compreenderem todos os meus momentos de ausência familiar.

A toda a família pela torcida...

Ao namorado Jenner Lopes (chuchu) pelos momentos compartilhados, pela alegria e pela luz que iluminaram os momentos de produção desta tese. 


\title{
AGRADECIMENTOS
}

\author{
"What is essential is invisible to the eye" \\ The Little Prince - Antoine-Marie-Roger de Saint-Exupéry
}

À Dra. Vivian Helena Pellizari, por aceitar uma goiana desconhecida em seu laboratório, pela orientação, pelas inúmeras oportunidades, pelo conhecimento compartilhado e por ter sido o alicerce na construção deste trabalho.

Ao Dr. Álvaro Bisol Serafini por praticamente me obrigar a sair de Goiás e buscar por novos caminhos na Universidade de São Paulo e ao Dr. José Daniel Gonçalves Vieira pela orientação de mestrado e por me apresentar à microbiologia ambiental.

À Dra. Cristine Chaves Barreto por ser amiga-mãe, por tornar possível minha vinda para São Paulo, pelos momentos de gargalhadas e de ensinamentos sobre ciência, biologia molecular e RPG.

Aos meus grandes amigos do Laboratório de Ecologia de Micro-organismos por todos os momentos de ajuda, alegria e compartilhamento: Simone Tessaro (par de vaso), Ana Carolina, Rubens Duarte, Débora Linhares, Fabiana Paula, Priscila Ikeda, Cristina Nakayama, Juliana Cedro, Sandra Nishio, Emanuele Kuhn, Laura Piai, Adriana Lopes, Adriana Torres, André Rosch, Diego Castillo, Felipe Nóbrega, além da nossa amada Rosa Gamba.

Aos meus amigos assessores científicos e estatísticos: Rubens Duarte, Fernando Dini Andreote, Armando Cavalcante Dias, Ederson da Conceição Jesus e Diogo Paes. Obrigada pela prestatividade, disponibilidade e por não medirem esforços para ajudar a tornar este trabalho melhor. Também agradeço aos amigos Jansen de Araújo e Rodrigo Taketani pelos ensinamentos sobre PCR em tempo real.

Ao Prof. Dr. Itamar Soares de Melo por permitir que eu fizesse parte de um seleto grupo de pessoas maravilhosas que integram o Projeto BIOTA/FAPESP intitulado "Biodiversidade e atividades funcionais de micro-organismos de manguezais do estado de São Paulo”. E também aos divertidos amigos de coleta da ESALQ e EMBRAPA: João, Armando, Fernando, Ricardo, Cibele e Lucianas.

À CAPES pela concessão da bolsa de estudos (Processo BEX 4353/11-0) e pela oportunidade de estágio no exterior.

Ao Prof. Dr. James Tiedje, pelas inúmeras oportunidades concedidas e por viabilizar a realização de tantos experimentos deste trabalho em seu laboratório. Aos amigos do Center for Microbial Ecology Tim, Jie e Marius por toda a receptividade e por tornarem a estadia em 
Michigan muito mais agradável. À equipe do Ribosomal Database Project pelo auxílio nas análises dos dados de pirosequenciamento, especialmente aos doutores Benli, Qiong e James Cole. À equipe do Dr. Jizhong Zhou do Institute for Environmental Genomics pela realização da técnica de Microarranjo, especialmente Yuan Tong e Joy D. Van Nostrand.

Aos amigos brasileiros da Michigan State University: Alessandra Dametto, Fernanda Paes, Angélica Santos, Juliana Sacoman, Paulo Pires, Lorena Souza, Fabiane Staschower, Flávia Carneiro e Bruna Lourenção pelos momentos de descontração e alegria.

Aos membros da banca de qualificação: Dra. Cristine Chaves Barreto, Dr. Fernando Dini Andreote, Dra. Irma Nelly Gutierrez Rivera, Dra. Raquel Peixoto e Dra. Suzan Pantaroto, por suas preciosas sugestões, críticas e por enriquecerem o trabalho.

Aos professores e funcionários do ICB/USP meus agradecimentos por toda a ajuda prestada.

E a todos aqueles que, embora não mencionados, contribuíram de alguma forma para a realização deste trabalho. 
"Eu sei muito pouco. Mas tenho a meu favor tudo o que não sei - e por ser um campo virgem - está livre de preconceitos. Tudo o que não sei é minha parte melhor: é a minha largueza. É com ela que eu compreenderia tudo. Tudo o que não sei é o que constitui a minha verdade". 


\section{RESUMO}

LIMA, D. V. Análise da diversidade, abundância e estrutura funcional da comunidade microbiana de três manguezais do estado de São Paulo, Brasil. 2012. 209 f. Tese (Doutorado em Microbiologia) - Instituto de Ciências Biomédicas, Universidade de São Paulo, São Paulo, 2012.

Os manguezais são ecossistemas complexos e dinâmicos tipicamente encontrados na interface entre a terra e o mar. Apesar de sua grande importância ecológica e econômica estes ambientes estão em risco, devido à proximidade de áreas com influência antrópica e elevada exposição a poluentes, tais como os Hidrocarbonetos Policíclicos Aromáticos (HPAs) liberados em derramantos de petróleo. A literatura relata uma rica biodiversidade nos manguezais, mas pouco se sabe sobre o impacto dos HPAs na comunidade microbiana destes ambientes. Neste trabalho exploramos a diversidade e abundância taxonômica e funcional de bactérias em três manguezais localizados no Estado de São Paulo, sob diferentes estágios de preservação: a) uma região preservada (CP), b) uma região afetada por atividade antrópica (BA), e c) uma região previamente contaminada por vazamento de petróleo (BC). As amostras de sedimento foram coletadas em triplicata, ao longo de um transecto delimitando três regiões em cada manguezal: curso-d’água, floresta e restinga. Para todas as amostras foram realizadas: (1) análises físico-químicas; (2) medida da concentração de HPAs, (3) análise da diversidade do gene $\alpha$-ARHD envolvido na biodegradação de HPAs, (4) cultivo de bactérias por enriquecimento com bifenilo; (5) quantificação da abundância dos genes $16 \mathrm{~S}$ rRNA e $\alpha$-ARHD por PCR em tempo real, (6) investigação da diversidade bacteriana pelo pirosequenciamento dos genes 16S rRNA e bph (bifenilo dioxigenase) e (7) análise da estrutura funcional das comunidades pelo uso do GeoChip. Os resultados mostraram que a concentração total de HPAs variou de 60,7 a 827,7 ng.g $^{-1}$ e foi mais elevada no manguezal BC. O gene $\alpha$-ARHD foi detectado em todos os locais de amostragem, revelando maior diversidade em BC e a presença de enzimas envolvidas na biodegradação de bifenilo, naftaleno, dibenzofurano, 3-fenilpropanoato e benzeno. Bactérias isoladas por enriquecimento com bifenilo foram obtidas em sua maioria, dos manguezais BA e BC e os principais gêneros detectados foram Bacillus e Lysinibacillus. A PCR em tempo real demonstrou uma maior abundância dos genes $\alpha$-ARHD e 16S rRNA na área contaminada. A análise das 40.851 seqüências obtidas pelo pirosequenciamento do gene 16S rRNA mostrou que a diversidade e riqueza estimada para as amostras da área preservada foi superior à da área contaminada e que o filo mais frequente foi Proteobacteria e as classes dominantes Alpha e Gammaproteobacteria. Já as 12.410 seqüências do gene $b p h$ indicaram maior diversidade e riqueza no manguezal BA e os principais gêneros detectados foram Pseudomonas e Rhodococcus. Os resultados do GeoChip permitiram verificar uma maior riqueza de genes funcionais no manguezal BC, indicando que apesar da menor diversidade taxonômica detectada, a comunidade microbiana ali existente apresenta uma maior diversidade metabólica, especialmente relacionada aos genes envolvidos em processos de biorremediação e estresse. Em conclusão, a combinação de diferentes técnicas nos permitiu verificar uma maior diversidade taxonômica na área preservada, porém maior diversidade funcional nas áreas impactadas, evidenciando alterações na comunidade microbiana desses manguezais e indicando a importância da preservação desse ecossitema que apresenta um imenso potencial ecológico e biotecnológico. Os resultados também oferecem novas abordagens para o estudo da recuperação de manguezais impactados.

Palavras-chave: Manguezal. Microbiologia ambiental. Diversidade taxonômica. Diversidade funcional. PCR em tempo real. Pirosequenciamento. GeoChip. 


\begin{abstract}
LIMA, D. V. Analysis of diversity, abundance and functional structure of microbial community of three mangroves in São Paulo State, Brazil. 2012. 209 p. Ph.D Thesis (Microbiology) - Instituto de Ciências Biomédicas, Universidade de São Paulo, São Paulo, 2012.
\end{abstract}

Mangroves are complex and dynamic ecosystems typically found at the sea-land interface. Despite their great ecological and economic importance they are at risk, due to proximity to areas with high anthropogenic influence and exposure to pollutants, such as Polycyclic Aromatic Hydrocarbons (PAHs) released by oil spills. Several authors report a rich biodiversity in mangroves, but little is known about the impact of PAHs on this sediment microbial community structure. In this work we explored the diversity and abundance of taxonomic and functionally important bacteria in three mangroves located in São Paulo State under different stages of preservation: a) one pristine site used as reference area (CP), b) a site affected by anthropogenic activity (BA), and c) a site formerly contaminated by an oil spill. Sediment cores were collected in triplicate at each sampling site, along a transect from the sea to the land, delimiting three regions (1=sea; $2=$ forest, and $3=$ land) at each mangrove. For all sediment samples were performed: (1) physical-chemical analysis, (2) measure the total concentration of PAHs, (3) analysis of $\alpha$-ARHD gene diversity involved in PAH biodegradation, (4) growth of bacteria by enrichment with biphenyl, (5) quantify the abundance of 16S rRNA and $\alpha$-ARHD by real-time PCR, (6) investigation of bacterial diversity by pyrosequencing of 16S rRNA and bph (biphenyl dioxygenase) genes and (7) analysis of the functional structure of communities through GeoChip. Results showed that the total concentration of PAHs was higher in mangrove BC (817 $\mathrm{ng}^{\left.-\mathrm{g}^{-1}\right)}$ the previously contaminated mangrove. The $\alpha$-ARHD gene was detected in all sampling sites, revealing greater diversity in $\mathrm{BC}$ and showing the presence of genes annotated to be involved in biphenyl, naphthalene, dibenzofuran, 3-phenylpropanoate and benzene metabolism. Bacteria isolated by enrichment with biphenyl were obtained mostly from mangroves BA and BC and the main genera detected were Bacillus and Lysinibacillus. Real-time PCR demonstrated a greater abundance of $\alpha$-ARHD and 16S rRNA genes in contaminated area (BC). The analysis of 40,851 sequences obtained by pyrosequencing of the 16S rRNA gene showed that the diversity and richness estimated for pristine area was higher than in contaminated, and Proteobacteria was the most frequent phylum and the dominant classes were Alpha and Gammaproteobacteria. The 12,410 bph gene sequences showed greater diversity and richness in mangrove BA and the main bacterial genera were Pseudomonas and Rhodococcus. GeoChip results allowed verifying the greater richness of functional genes in mangrove BC, indicating that despite the lower bacterial diversity detected, the community living there has a higher metabolic diversity, especially related to genes involved in bioremediation and stress. In conclusion, the combination of different techniques allowed us to access a greater taxonomic diversity in pristine mangrove, but greater functional diversity in the impacted mangroves, showing that human action and contamination with $\mathrm{PAH}$ led to changes in the microbial community in these mangroves, indicating the importance of preserving this ecosystem that has immense environmental and biotechnological potential. The results also can provide new insights for improving the restoration of such environments.

Keywords: Mangrove. Taxonomic diversity. Functional diversity. qPCR. Pirosequencing. GeoChip 


\section{LISTA DE ILUSTRAÇÕES}

Figura 1. Mapa da distribuição dos manguezais no mundo.

Figura 2. Fotos dos manguezais de Bertioga e Cananéia (Ilha do Cardoso). 32

Figura 3. Estrutura dos principais hidrocarbonetos aromáticos. 36

Figura 4. Fórmula estrutural do bifenilo policlorado 40

Figura 5. Degradação de compostos aromáticos por micro-organismos aeróbios e anaeróbios, demonstrando os diferentes aceptores de elétrons na respiração.

Figura 6. Sistema de três componentes das dioxigenases. 45

Figura 7. Árvore filogenética das seqüências da subunidade alfa das enzimas ARHDs representando as famílias de dioxigenases.

Figura 8. Vias anaeróbias para a descloração do 2,3,4,6-clorobifenilo. 49

Figura 9. Via catabólica para a degradação aeróbia do bifenilo policlorado e organização do gene bph em Pseudomonas pseudoalcaligenes KF707. 51

Figura 10. Visão geral do método de pirosequenciamento. 57

Figura 11. Ilustração das etapas do pirosequenciamento 59

Figura 12. Esquema geral envolvendo as principais etapas da técnica de microarranjos de DNA (GeoChip). 63

Figura 13. Organograma da metodologia empregada no presente estudo. 66

Figura 14. Esquema dos pontos de amostragem em cada manguezal analisado. 68

Figura 15. Protocolo elucidando as etapas da metodologia de enriquecimento 74

Figura 16. Análise de Componentes Principais baseada nas características físico-químicas dos sedimentos de manguezais analisados. 88 
Figura 17. Análise de Componentes Principais baseada nas concentrações de HPAs dos sedimentos dos manguezais analisados.

Figura 18. Razão fluoranteno/pireno x Razão benzo(a)antraceno/criseno observada nos sedimentos dos manguezais analisados.

Figura 19. Classificação das bibliotecas do gene $\alpha$-ARHD pela utilização da ferramenta Tblastx a partir das amostras analisadas.

Figura 20. Árvore de similaridade construída a partir do alinhamento das seqüências representativas dos clones do manguezal de Bertioga Antropizado e as seqüências de referência das enzimas ARHD. 98

Figura 21. Árvore de similaridade construída a partir do alinhamento das seqüências representativas dos clones do manguezal de Bertioga Contaminado e as seqüências de referência das enzimas ARHD. 99

Figura 22. Árvore de similaridade construída a partir do alinhamento das seqüências representativas dos clones do manguezal de Cananéia Preservado e as seqüências de referência das enzimas ARHD.

Figura 23. Curvas de rarefação estimadas para o número total de sequências do gene $\alpha$ ARHD de cada manguezal para os cutoffs de 0,03; 0,05; 0,10 e 0,20. 104

Figura 24. Curvas de rarefação estimadas para o número total de sequências do gene $\alpha$ ARHD para cada ponto amostral para os cutoffs de 0,03; 0,05; 0,10 e 0,20..... 105

Figura 25. Diagramas de Venn baseados nas OPFs das bibliotecas do gene $\alpha$-ARHD (cutoff $0,05)$

Figura 26. Árvore filogenética construída a partir das sequências parciais do gene 16S rRNA dos isolados e sequências de referência com maiores valores de identidade do banco de dados do RDP. 113

Figura 27. Curvas de amplificação (A1 e B1), curvas de dissociação (A2 e B2) e curvaspadrão (A3 e B3) para confirmar a amplificação específica dos fragmentos dos genes 16S rRNA (A) e $\alpha$-ARHD (B) das amostras de sedimento dos manguezais. 
Figura 28. Média da abundância dos genes $16 \mathrm{~S}$ rRNA e $\alpha$-ARHD pela técnica de qPCR, nos diferentes pontos amostrais analisados (I) e entre manguezais (II). 122

Figura 29. Ranking dos 25 gêneros mais abundantes obtidos para cada manguezal por meio da técnica de prirosequenciamento para o gene $16 \mathrm{~S}$ rRNA.

Figura 30. Frequência relativa dos diferentes táxons de Bacteria, obtidos por pirosequenciamento do gene 16S rRNA para cada manguezal analisado, com base na afiliação filogenética do RDP. 126

Figura 31. Frequência relativa dos diferentes táxons de Bacteria, obtidos por pirosequenciamento do gene 16S rRNA para cada ponto amostral, com base na afiliação filogenética do RDP. 127

Figura 32. Frequência relativa dos gêneros encontrados em cada classe do Filo Proteobacteria nas amostras analisadas. 132

Figura 33. Frequência relativa dos principais gêneros encontrados nos Filos: Firmicutes (A) e Actinobacteria (B). 134

Figura 34. Mapa de cores com análise de agrupamento das amostras baseado na abundância de filos encontrada. 136

Figura 35. Análise de Componentes Principais correlacionando os filos encontrados pelo pirosequenciamento do gene 16S rRNA, as características físico-químicas e concentrações de Hidrocarbonetos Policíclicos Aromáticos (HPAs) para cada amostra de sedimento analisada.

Figura 36. Curvas de rarefação estimadas para o número total de sequências do gene $16 \mathrm{~S}$ rRNA de cada manguezal para os cutoffs de 0,03; 0,05, 0,10 e 0,20. 142

Figura 37. Curvas de rarefação estimadas para o número total de sequências do gene $16 \mathrm{~S}$ rRNA obtidas em cada ponto amostral dos três manguezais para os cutoffs de 0,$03 ; 0,05 ; 0,10$ e 0,20 . 143

Figura 38. Diagramas de Venn representando o número de OTUs únicas e compartilhadas entre as amostras de de cada manguezal. Valor de cutoff $=0,20$. 146 
Figura 39. Abundância relativa dos principais gêneros de Bacteria, que apresentaram o gene bph em cada manguezal analisado, com base na afiliação filogenética do NCBI/GenBank utilizando-se a ferramenta Tblastx.

Figura 40. Abundância relativa dos principais gêneros bacterianos que apresentam o gene $b p h$, em cada ponto amostral analisado, com base na afiliação filogenética do NCBI/GenBank utilizando-se a ferramenta Tblastx. 152

Figura 41. Mapa de cores com análise de agrupamento as amostras baseado na abundância de gêneros bacterianos encontrados pela análise do gene $b p h$. 153

Figura 42. Análise de Componentes Principais correlacionando os gêneros bacterianos associados ao gene $b p h$, as características físico-químicas e concentrações de HPAs para cada amostra de sedimento analisada. 154

Figura 43. Curvas de rarefação estimadas para o número total de sequências de aminoácidos do gene $b p h$ para cada manguezal para os cutoffs de 0,03; 0,05; 0,10 e 0,20...159

Figura 44. Curvas de rarefação estimadas para as sequências de aminoácidos do gene $b p h$ para cada ponto amostral dos três manguezais para os cutoffs de 0,$03 ; 0,05 ; 0,10$ e 0,20 .

Figura 45. Diagrama de Venn representando o número de OPFs únicas e compartilhadas entre as amostras de sedimento de cada manguezal. Valor de cutoff $=0,20 \ldots 162$

Figura 46. Riqueza de genes funcionais nas amostras de sedimento dos manguezais analisados.

Figura 47. Riqueza de famílias de genes funcionais nas amostras de sedimento dos manguezais analisados. 168

Figura 48. Diagramas de Venn apresentando o número de sondas únicas e compartilhadas entre os manguezais. 169

Figura 49. Riqueza de processos funcionais detectados nas amostras de sedimento dos manguezais analisados. 
Figura 50. Dendograma de cores com análise de agrupamento baseada na abundância de genes funcionais detectada pelo GeoChip.................................................... 172

Figura 51. Ordenação em escala multidimensional não métrica (NMDS) da estrutura funcional das comunidades microbianas dos sedimentos dos manguezais

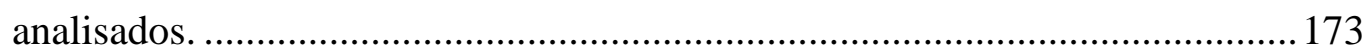




\section{LISTA DE QUADROS}

Quadro 1. Ocorrências envolvendo derramamentos e vazamentos de petróleo e derivados no Estado de São Paulo (1974 - 2012)...... 34

Quadro 2. Principais Hidrocarbonetos Policíclicos Aromáticos reportados em análises químicas e estudados quanto a sua carcinogenicidade, ocorrência e toxicidade ...39

Quadro 3. Caracterização das sondas presentes na lâmina do GeoChip 4.0 65

Quadro 4. Localização geográfica dos manguezais amostrados no Estado de São Paulo.....67

Quadro 5. Informações sobre a reação de qPCR para os genes $16 \mathrm{~S}$ rRNA e $\alpha$-ARHD......... 78

Quadro 6. Sequências nucleotídicas dos primers utilizados na realização da PCR para o pirosequenciamento de cada amostra. 82 


\section{LISTA DE TABELAS}

Tabela 1. Análises físico-químicas dos pontos analisados dentro dos manguezais. 88

Tabela 2. Concentração de Hidrocarbonetos Policíclicos Aromáticos (ng.g ${ }^{-1}$ peso seco) nas amostras de sedimento dos manguezais analisados 90

Tabela 3. Acompanhamento das concentrações totais de HPAs ( $\Sigma$ - HPAs) e do bifenilo no óleo do derramamento e nas amostras de Bertioga (BC) nos anos de 2001, 2005 e 2009.

Tabela 4. Número de OPFs e índices de alfa-diversidade estimados para as sequências de aminoácidos obtidas através do sequenciamento para o gene $\boldsymbol{\alpha}$-ARHD para cada manguezal. 102

Tabela 5. Número de OPFs e índices de alfa-diversidade estimados para as sequências de aminoácidos obtidas através do sequenciamento para o gene $\boldsymbol{\alpha}$-ARHD para os pontos amostrais do manguezal de Bertioga Antropizado. 102

Tabela 6. Número de OPFs e índices de alfa-diversidade estimados para as sequências de aminoácidos obtidas através do sequenciamento para o gene $\boldsymbol{\alpha}$-ARHD para os pontos amostrais do manguezal de Bertioga Contaminado. 103

Tabela 7. Número de OPFs e índices de alfa-diversidade estimados para as sequências de aminoácidos obtidas através do sequenciamento para o gene $\boldsymbol{\alpha}$-ARHD para os pontos amostrais do manguezal de Cananéia.

Tabela 8. Índices de beta-diversidade calculados entre as amostras dentro de cada manguezal para o cutoff de 0,05 . 106

Tabela 9. Teste de hipótese Libshuff entre as amostras dos três manguezais, sob um cutoff de 0,05 . 108

Tabela 10. Filotipos representativos dos gêneros bacterianos isolados a partir das amostras de sedimento dos manguezais enriquecidos com bifenilo.

Tabela 11. Descrição das amostras submetidas ao pirosequenciamento, número total e comprimento médio das sequências. 
Tabela 12. Número de OTUs e índices de alfa-diversidade estimados para as sequências obtidas por pirosequenciamento do gene 16S rRNA dos manguezais analisados.

Tabela 13. Número de OTUs e índices de alfa-diversidade estimados para as sequências dos pontos amostrais do manguezal de Bertioga Antropizado obtidas através do pirosequenciamento do gene $16 \mathrm{~S}$ rRNA..................................................... 140

Tabela 14. Número de OTUs e índices de alfa-diversidade estimados para as sequências dos pontos amostrais do manguezal de Bertioga Contaminado obtidas através do pirosequenciamento do gene $16 \mathrm{~S}$ rRNA. 141

Tabela 15. Número de OTUs e índices de alfa-diversidade estimados para as sequências dos pontos amostrais do manguezal de Cananéia obtidas através do pirosequenciamento do gene $16 \mathrm{~S}$ rRNA.

Tabela 16. Índices de beta-diversidade calculados entre as amostras dentro de cada manguezal para o cutoff de 0,20 . 144

Tabela 17. Teste de hipótese Libshuff entre as amostras dos três manguezais, sob um cutoff de 0,20 . 147

Tabela 18. Descrição das amostras submetidas ao pirosequenciamento para o gene $b p h$, número total e comprimento médio das sequências.

Tabela 20. Número de OPFs e índices de alfa-diversidade estimados para as sequências de aminoácidos obtidas através do pirosequenciamento para o gene bph para os pontos amostrais do manguezal de Bertioga Antropizado 157

Tabela 21. Número de OPFs e índices de alfa-diversidade estimados para as sequências de aminoácidos obtidas através do pirosequenciamento para o gene bph para os pontos amostrais do manguezal de Bertioga Contaminado. 158

Tabela 22. Número de OPFs e índices de alfa-diversidade estimados para as sequências de aminoácidos obtidas através do pirosequenciamento para o gene $b p h$ para os pontos amostrais do manguezal de Cananéia. 158 
Tabela 23. Índices de beta-diversidade calculados entre as amostras dentro de cada manguezal para o cutoff de 0,20 . 161

Tabela 24. Teste de hipótese Libshuff entre as amostras dos três manguezais, sob um cutoff de 0,20 . 163

Tabela 25. Número de genes dos diferentes grupos de processos funcionais detectados nas amostras de sedimentos dos manguezais. 165

Tabela 26. Número de sondas de genes relacionados a diferentes processos que apresentaram hibridização positiva nas amostras analisadas. 166 


\section{LISTA DE ABREVIAÇÕES}

ARHD Aromatic Ring Hydroxylating Dioxygenase (Dioxigenase que Hidroxila Anel Aromático)

bph Gene que codifica a enzima bifenilo dioxigenase

BA Bertioga - manguezal que sofre ação antrópica

BC Bertioga - manguezal previamente contaminado com petróleo

CP Cananéia - manguezal preservado (área controle)

dNTP Deoxyribonucleotide Triphosphates (Desoxiribonucleotídeos Trifosfatados)

DNA Deoxyribonucleic Acid (Ácido Desoxirribonucleico)

EDTA Ethylenediamine Tetraacetic Acid (Ácido Etilenodiamino Tetra-acético)

FGA Functional Gene Array (Arranjo de Genes Funcionais)

HPAs Hidrocarbonetos Policíclicos Aromáticos

NCBI National Center for Biotechnology Information

OPF Operational Protein Family (Família Proteica Operacional)

OTU Operational Taxonomic Unit (Unidade Taxonômica Operacional)

pb Pares de base

PCB Polyclorinated Biphenyl (Bifenilo Policorado)

PCR Polymerase Chain Reaction (Reação em Cadeia da Enzima Polimerase)

POP Poluente Orgânico Persistente

qPCR PCR quantitative (PCR em tempo real)

RNA Ribonucleic Acid (Ácido Ribonucleico)

rRNA Ribosomal Ribonucleic Acid (RNA ribossomal)

TAE Tris - Acetato - EDTA

Tblastn Basic Local Alignment Search Tool for Nucleotide

Tblastx Basic Local Alignment Search Tool for Translated Nucleotide 


\section{SUMÁRIO}

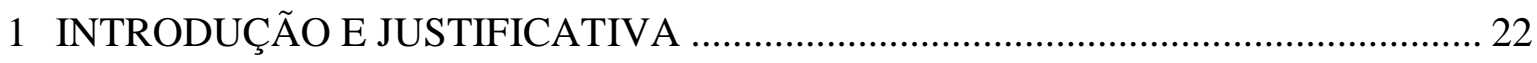

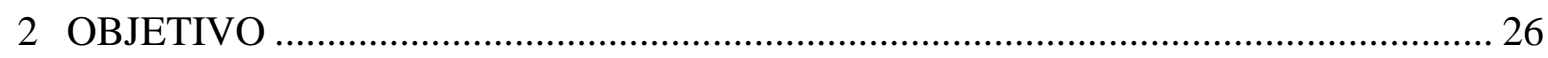

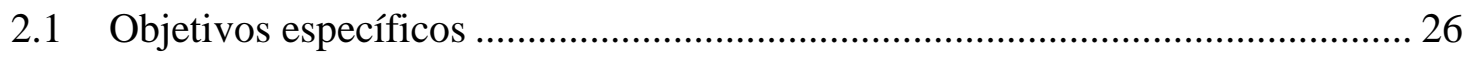

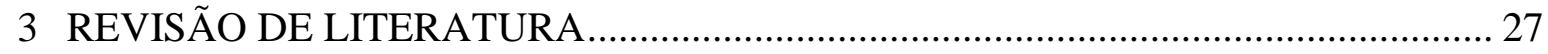

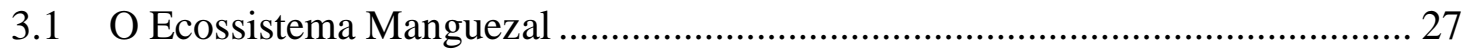

3.2 Manguezais de São Paulo - Áreas de Estudo ................................................... 30

3.3 Petróleo e Hidrocarbonetos Aromáticos ........................................................ 35

3.4 Bactérias Envolvidas na Biodegradação de Hidrocarbonetos............................ 41

3.5 Enzimas ARHDs (Dioxigenases que Hidroxilam Anéis Aromáticos)................ 44

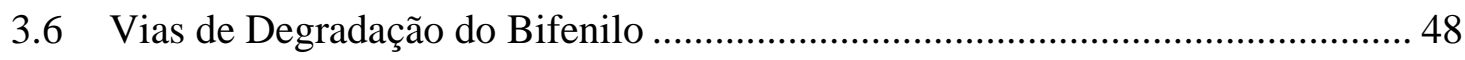

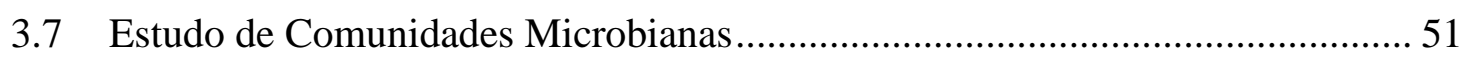

3.8 A Técnica de PCR em Tempo Real .............................................................. 53

3.9 Sequenciamento e Pirosequenciamento …................................................... 55

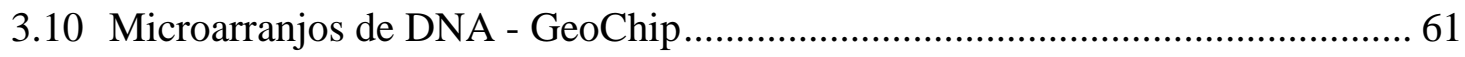

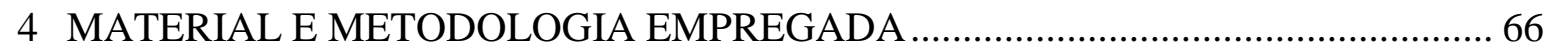

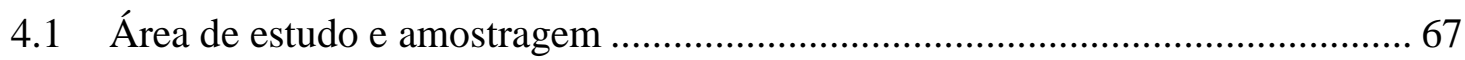

4.2 Análise dos parâmetros físico-químicos e medidas de Hidrocarbonetos............. 68

4.3 Extração do DNA total das amostras de sedimento..........................................69

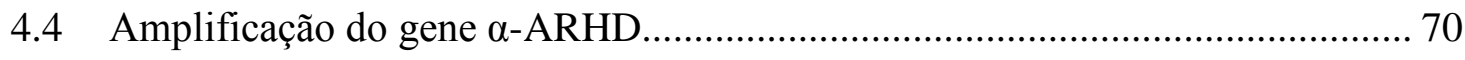

4.4.1 Clonagem dos fragmentos amplificados ............................................ 70

4.4.2 Sequenciamento e análises filogenéticas ............................................... 72

4.5 Seleção de bactérias degradadoras de bifenilo................................................ 73

4.5.1 Identificação dos micro-organismos e análises filogenéticas .................... 75

4.6 Quantificação dos genes 16S rRNA e $\alpha$-ARHD por PCR em tempo real .......... 76

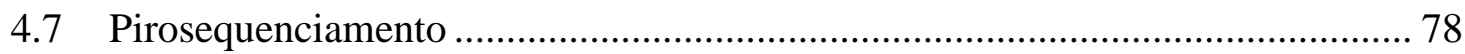


4.7.1 Pirosequenciamento do gene 16S rRNA …................................................ 80

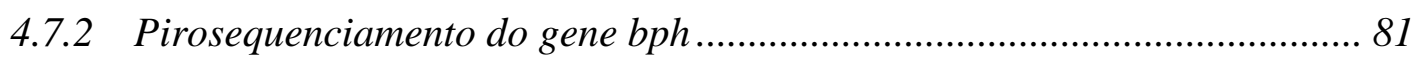

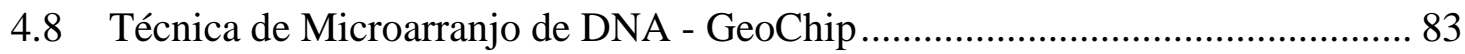

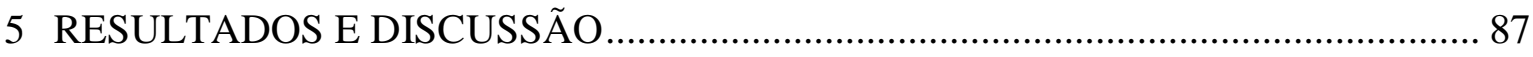

5.1 Análises físico-químicas e de hidrocarbonetos totais ........................................ 87

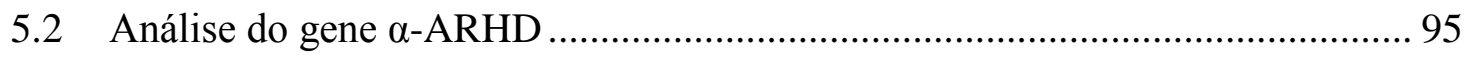

5.3 Isolados obtidos pelo enriquecimento com bifenilo .................................... 111

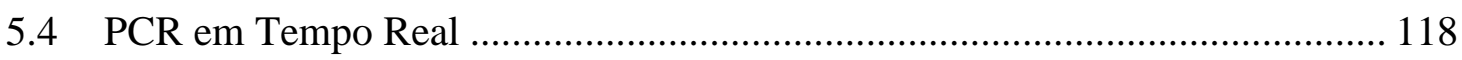

5.5 Pirosequenciamento para o gene 16S rRNA................................................ 123

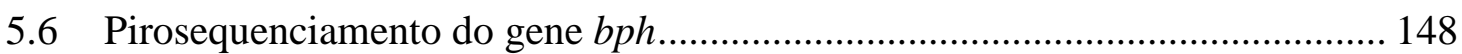

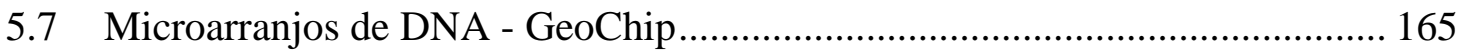

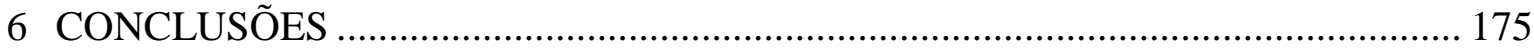

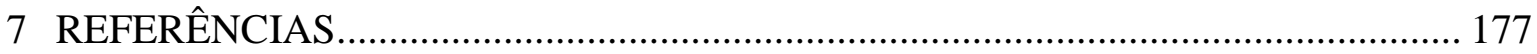




\section{INTRODUÇÃO E JUSTIFICATIVA}

Os avanços tecnológicos resultantes do desenvolvimento industrial trouxeram muitos benefícios para a sociedade, mas também algumas consequências como o aumento e a liberação de diversos tipos de poluentes, denominados compostos recalcitrantes, que podem persistir no meio ambiente por longos períodos de tempo. No Brasil, a indústria do petróleo é um exemplo desse desenvolvimento, que tem propiciado um crescimento econômico intenso nos últimos anos, todavia, ela é igualmente uma importante fonte de poluição ambiental.

Os manguezais, devido a sua posição ao longo da linha costeira, são constantemente expostos à contaminação por petróleo proveniente de derramamentos contínuos e/ou acidentais, sendo considerados os ecossistemas mais sensíveis e vulneráveis aos efeitos deste poluente, pois apresentam características que favorecem a permanência e o acúmulo de derivados de petróleo em seus solos. Esses compostos podem causar desequilíbrio nos processos essenciais para a manutenção dos manguezais, incluindo modificações nos ciclos biogeoquímicos.

Os hidrocarbonetos constituem os constituintes majoritários do petróleo, sendo que os Hidrocarbonetos Policíclicos Aromáticos (HPAs) de origem antrópica são compostos tóxicos, carcinogênicos e considerados contaminantes ambientais. Já os Bifenilos Policlorados (PCBs - Polyclorinated Biphenyls) são hidrocarbonetos aromáticos produzidos comercialmente e estão incluídos entre os principais Poluentes Orgânicos Persistentes (POPs). Estes HPAs aderem-se fortemente a partículas suspensas e acumulam-se nos sedimentos dos manguezais devido a sua intrínseca estabilidade química, baixa solubilidade e hidrofobicidade.

O principal processo e o de menor custo para eliminação de HPAs do ambiente é a biodegradação microbiana. Nesse sentido, os micro-organismos encontrados em solos de manguezais possuem papel fundamental nas transformações bioquímicas de nutrientes e matéria orgânica e são essenciais na degradação dos HPAs. Esta capacidade de degradação é realizada devido à presença de complexos enzimáticos diversificados presentes principalmente em bactérias.

As enzimas ARHDs (Dioxigenases que Hidroxilam Anéis Aromáticos - Aromatic Ring Hydroxylating Dioxygenases) são codificadas pelo gene $\alpha$-ARHD e estão envolvidas na degradação dos mais diversos compostos aromáticos incluindo benzeno, naftaleno, tolueno, bifenilo, xileno, dentre outros. Os genes catabólicos que codificam para a produção destas enzimas recebem grande atenção como indicadores da degradação de compostos recalcitrantes em áreas impactadas, e considerando-se a grande diversidade estrutural de 
hidrocarbonetos na natureza, é passível de se esperar que a diversidade destas enzimas seja também significativa, apresentando grande potencial de aplicação biotecnológica.

No Brasil os primeiros estudos relacionados à pesquisa de genes associados à biodegradação de hidrocarbonetos aromáticos foram realizados por Pellizari e colaboradores (1996), que buscavam comparar a competência na degradação de PCBs por bactérias isoladas do Rio Pinheiros (SP) e de solos contaminados de Cubatão (SP) a partir do enriquecimento empregando naftaleno ou bifenilo como única fonte de carbono. Os padrões de hibridização obtidos através da técnica de Southern-Blot para as sondas que codificavam os genes bph (bifenilo), nah (naftaleno) e tod (tolueno), indicaram que as mesmas não poderiam prever a capacidade de degradação dos isolados. Também foi relatada a presença de múltiplas dioxigenases em alguns dos isolados, sugerindo a existência de grande diversidade de genes catabólicos ainda não descritos.

Visando dar continuidade aos estudos sobre a diversidade do gene $\alpha$-ARHD, o grupo integrou o BIOTA/FAPESP (98/05068-0) e escolheu a região do estuário de Santos e São Vicente (impactada pelas inúmeras contribuições de origem doméstica e industrial) para a pesquisa dos genes $n d o B$ (naftaleno dioxigenase), todC1 (tolueno dioxigenase), xylE (xileno dioxigenase), cat2,3 (catecol dioxigenase) e bphA1 (bifenilo dioxigenase). Os isolados obtidos foram avaliados quanto à capacidade de degradação de tolueno, xileno, nonano e naftaleno e aproximadamente 50\% das bactérias apresentaram capacidade de degradar os hidrocarbonetos testados, como descrito nos trabalhos de Bertacini (1998), Luz (2001) e Sakata (2004).

Posteriormente Rodrigues e colaboradores (2009) realizaram a caracterização de cepas do gênero Klebsiella degradadoras de hidrocarbonetos isoladas dos sedimentos dos estuários de Santos e São Vicente, mas apesar da capacidade de degradação descrita para estes isolados, apenas duas das cepas amplificaram o gene todC1, que codifica a enzima tolueno dioxigenase. Este e outros resultados anteriores (LOPEZ, 2002; RODRIGUES, 2002) evidenciaram que tanto os isolados quanto os consórcios degradadores de hidrocarbonetos e PCBs obtidos das amostras de solos e sedimentos estuarinos brasileiros, não apresentaram resposta satisfatória frente ao emprego dos primers descritos na literatura para pesquisa de genes catabólicos. Estes resultados sugeriram a ocorrência de genótipos catabólicos ainda não descritos no ambiente.

Um fator importante a se considerar é que os estudos iniciais sobre diversidade de degradadores isolados nas amostras do Brasil podem ter sido limitados pelas técnicas de cultivo, interferindo na detecção dos genes presentes na comunidade microbiana in situ. Desta forma, o conhecimento da presença dos genes catabólicos através de técnicas moleculares 
independentes de cultivo, passou a ser fundamental para responder se os genótipos descritos na literatura, a maioria em países temperados, estariam ou não presentes nas amostras brasileiras estudadas.

Paralelamente às pesquisas no Brasil, o grupo iniciou o desenvolvimento de estudos junto ao Programa Antártico Brasileiro. Luz e colaboradores (2004) propiciaram a continuidade dos trabalhos com enfoque na biogeografia e verificando, pelo uso de técnicas de PCR e hibridização, a presença dos genes ndoB, todC1, xylE, cat2,3 e bphA1 em amostras de solo contaminadas por óleo, localizadas ao redor dos tanques de armazenamento da Estação Cientifica Comandante Ferraz. A presença dos genes sugeriu o potencial da área para biorremediação. Este potencial foi confirmado em trabalho posterior também realizado por Luz e colaboradores (2006) quando microcosmos in situ foram construídos e os solos acompanhados por dois anos através das contagens de micro-organismos, micronutrientes, analises físico-químicas e concentração de hidrocarbonetos.

A possibilidade da presença de novos sistemas genéticos catabólicos (endêmicos) envolvidos na degradação de poluentes orgânicos nas diferentes áreas geográficas tornou fundamental a construção de bibliotecas metagenômicas, sem a limitação do emprego dos primers específicos. Desta forma, o estudo da presença de genes catabólicos através do emprego de primers não-específicos (degenerados), aplicados à metodologia independente de cultivo, visou revelar a presença do gene $\alpha$-ARHD em micro-organismos ainda não cultivados ou de difícil isolamento, assim como propiciar a identificação de novos genes e enzimas catabólicas. Para isto foi necessário o desenho de iniciadores degenerados, realizado como parte da tese de doutorado de Belicanta (2004).

No trabalho realizado por Leigh e colaboradores (2007), esses primers degenerados foram empregados no estudo de amostras de rizosfera de solos contaminados por PCBs. Este representou um importante avanço por avaliar as respostas do primer junto a um novo habitat, a rizosfera, e também por comparar as informações fornecidas por este iniciador como aquelas obtidas por novas técnicas moleculares empregadas em ecologia de microorganismos, como a técnica do Stable Isotope Probing (SIP) e microarranjo para genes funcionais (Geochip).

Outro avanço na linha de pesquisa foi realizado por Luz e colaboradores (2010) com a utilização da técnica de PCR em tempo real (qPCR), empregada com o objetivo de quantificar as cópias do gene $\alpha$-ARHD nos solos ao redor dos tanques de óleo da EACF. A qPCR revelou um baixo número de cópias do gene, no entanto, a concentração dos hidrocarbonetos 
encontrados naqueles solos também foi baixa quando comparada a áreas poluídas de países temperados.

Os resultados obtidos com a utilização dos primers degenerados para detecção do gene $\alpha$ ARHD possibilitaram também o emprego dos estimadores riqueza e índices de diversidade aplicados à ecologia molecular de micro-organismos, que foram utilizados por Kuhn (2007) ao analisar amostras de sedimento da Antártica, bem como por Silva (2011) ao trabalhar com amostras de solos de Terra Preta de Índio da Amazônia.

No contexto de complementação do estudo da diversidade e abundância do gene $\alpha$ ARHD nos mais diversos ambientes, o trabalho se propôs a contribuir com a análise deste gene na comunidade bacteriana em três regiões de manguezais do Estado de São Paulo. Nesse sentido os manguezais localizados nas cidades de Bertioga (região contaminada com petróleo e região que sofre com ação antrópica) e Cananéia (região preservada) foram selecionados como áreas de estudo para o Projeto Temático "Biodiversidade e Atividades Funcionais de Micro-organismos de Manguezais do Estado de São Paulo” (BIOTA/ FAPESP Processo 04/13910-6).

Nossa proposta de inovação para esta linha de pesquisa foi o emprego da técnica de pirosequenciamento dos genes 16S rRNA e $b p h$, em associação com a PCR em tempo real e microarranjos de DNA (GeoChip), com o intuito de entendermos de maneira mais profunda e conclusiva como a comunidade microbiana responde às alterações ambientais presentes nos distintos manguezais, ou mesmo em diferentes pontos dentro de um mesmo manguezal. Dessa forma buscamos auxiliar com um melhor entendimento destes genes no ecossistema manguezal, e dar suporte a projetos de pesquisa que visem a biorremediação.

Nossa hipótese de trabalho é que a contaminação do sedimento no manguezal de Bertioga alterou a estrutura da comunidade bacteriana autóctone daquele local, causando seleção, levando a uma redução na diversidade da população bacteriana total e favorecendo as comunidades de bactérias com capacidade metabólica para degradação de hidrocarbonetos. Também com o avanço no conhecimento da diversidade do gene $\alpha$-ARHD até o momento, acreditamos que a análise do número de cópias deste gene associada ao emprego de novas técnicas como o pirosequenciamemto e Geochip poderá retratar melhor o resultado da poluição por HPAs do que o estudo da diversidade destes genes através das técnicas de clonagem e sequenciamento já utilizadas. 


\section{OBJETIVO}

O presente projeto teve como objetivo geral contribuir com o conhecimento dos genes $\alpha$-ARHDs em novos ambientes, além de caracterizar, em seu aspecto taxonômico e funcional, a comunidade bacteriana presente no sedimento de três manguezais com diferentes históricos de preservação, bem como avaliar o efeito do impacto da contaminação por HPAs sobre essa comunidade, através da análise filogenética e emprego de técnicas tradicionais e moleculares, como descrito nos objetivos específicos a seguir:

\subsection{Objetivos específicos}

O presente estudo é dividido nos seguintes objetivos específicos:

a) Caracterizar os sedimentos dos manguezais estudados quanto aos seus parâmetros físico-químicos bem como a medida da concentração total de Hidrocarbonetos Policíclicos Aromáticos (HPAs), investigando quais atributos estão correlacionados com os parâmetros bióticos (comunidade bacteriana);

b) Verificar, pela construção de bibliotecas de clones, a presença e diversidade do gene $\alpha$-ARHD, associando à detecção e concentração de HPAs nos manguezais analisados;

c) Isolar e caracterizar os principais gêneros bacterianos envolvidos na biodegradação de bifenilo nestes manguezais;

d) Quantificar o número de cópias dos genes 16S rRNA e $\alpha$-ARHD pelo uso da técnica de PCR em tempo real (qPCR) com a finalidade de estabelecer relações entre o número de cópias e a diversidade desses genes nos manguezais analisados;

e) Avaliar a diversidade microbiana taxonômica e funcional, pelo emprego do pirosequenciamento dos genes $16 \mathrm{~S}$ rRNA e $b p h$, com o intuito de verificar se os diferentes históricos de contaminação dos manguezais refletem a diversidade da comunidade microbiana nesses ambientes;

g) Utilizar a técnica de microarranjos de DNA (Geochip) para comparar o potencial metabólico e a riqueza de genes funcionais associados à biodegradação de compostos orgânicos e aos ciclos biogeoquímicos nos diferentes manguezais analisados. 


\section{REVISÃO DE LITERATURA}

\subsection{O Ecossistema Manguezal}

Os manguezais são ecossistemas complexos e altamente produtivos, cuja distribuição biogeográfica é confinada a regiões costeiras, entre os trópicos de Câncer e Capricórnio se estendendo das latitudes $30^{\circ} \mathrm{N}$ a $30^{\circ} \mathrm{S}$, na interface entre ambientes terrestres, marinhos e de água doce, de regiões tropicais e subtropicais, (GIRI et al., 2008; HOLGUIN et al., 2001; JENNERJAHN et al., 2002). Ocorrem em uma variedade de condições ambientais, sendo localizados às margens de baías, enseadas, barras, desembocaduras de rios, lagunas e reentrâncias costeiras, onde exista o encontro das águas de rios com a do mar (SCHAEFFERNOVELLI, 2000; SCHAEFFER-NOVELLI et al., 1990a).

As maiores extensões de manguezais são encontradas na Ásia (42\%), África (20\%), América do Norte e Central (15\%), Oceania (12\%) e América do Sul (11\%). O Brasil ocupa a terceira posição em termos de áreas de manguezais, com uma extensão total de 962.683 hectares, onde os manguezais são encontrados entre as latitudes $04^{\circ} 30^{\prime} \mathrm{N}$ e $28^{\circ} 30^{\prime} \mathrm{S}$, conforme ilustrado na Figura 1 (GIRI et al., 2011).

Figura 1. Mapa da distribuição dos manguezais no mundo.

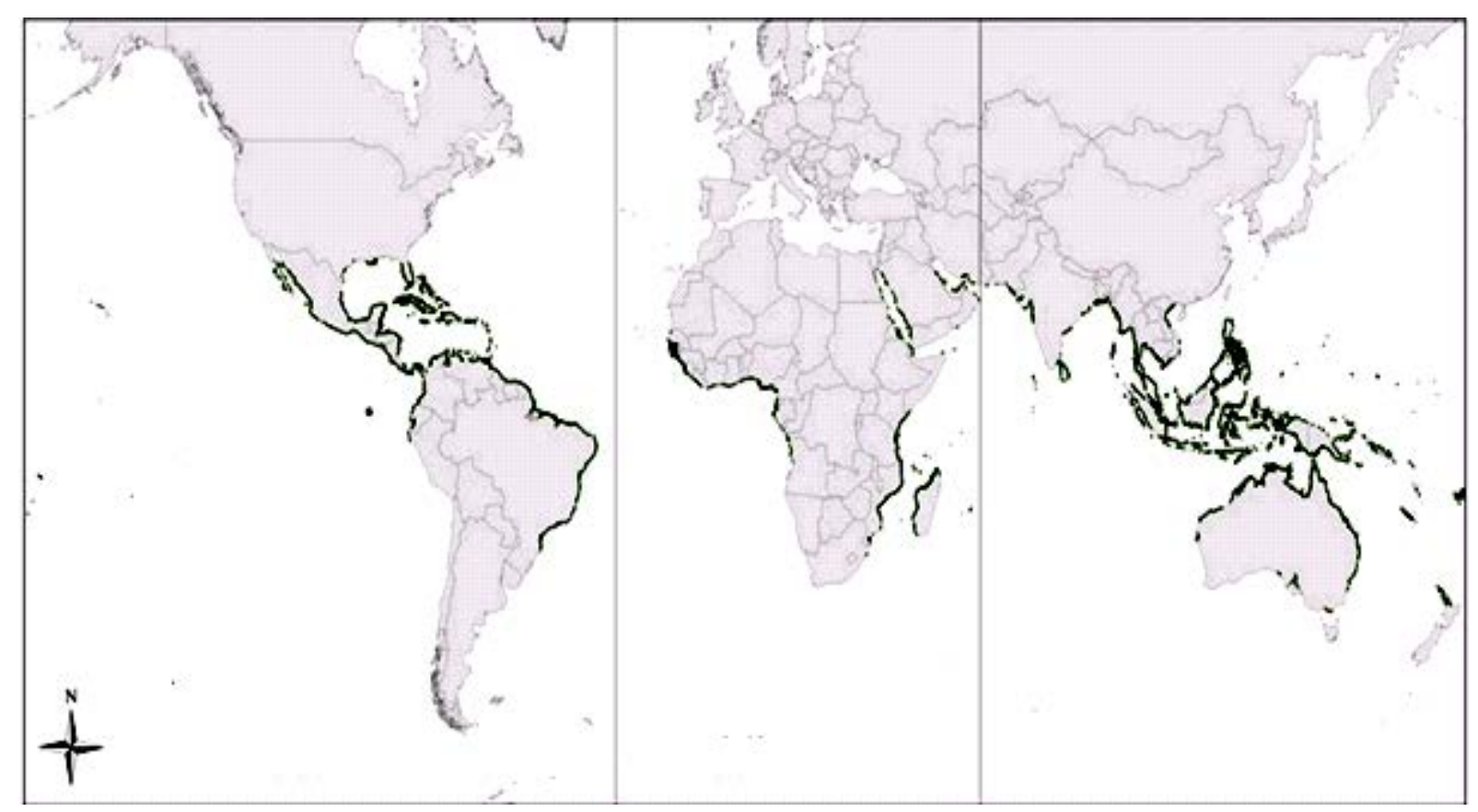

Fonte: Sikamäki et al. (2012), adaptado de Giri et al. (2011). 
Os bosques de mangue podem apresentar diferenças importantes em sua estrutura e funcionamento de acordo com a região, obedecendo a grande número de fatores e processos ambientais, tais como a uniformidade de condições hidrológicas, oceanográficas, fisiológicas e climáticas. No Brasil ocorrem apenas sete espécies arbóreas de mangue, distribuídas em quatro gêneros: Rhizophora, Avicennia, Laguncularia e Conocarpus (CUNHA-LIGNON, 2001; SCHAEFFER-NOVELLI, 2000; SCHAEFFER-NOVELLI et al., 1990a).

Os manguezais desempenham um papel essencial na manutenção da biodiversidade oceânica, funcionando como berçário e fontes de alimento para peixes e outros animais, além de fixador de sedimento (CUNHA-LIGNON et al., 2009b; PAES, 2008). Do ponto de vista ecológico, a importância destes ecossistemas consiste em manter a base alimentar da cadeia trófica, evitar a erosão do solo pelas marés, propiciar uma barreira de proteção contra ciclones e tsunamis, bem como reduzir o assoreamento dos portos e diminuir os impactos decorrentes da lixiviação de compostos químicos (BAIRD et al., 2009; DAS et al., 2009; KATHIRESAN et al., 2001) e são fonte de alimento e subsistência para populações humanas além de oferecerem recursos geradores de divisas para o país.

Os manguezais geralmente se desenvolvem em áreas geomorfologicamente ativas possuindo solos halomórficos, formados pela deposição de partículas de origem continental e marinha, orgânicas e inorgânicas, que estão em suspensão na água e se movimentam em função das correntes de fluxo e refluxo das marés (PRADA-GAMERO et al., 2004). No geral estes solos são lodosos ou lamo-arenosos, profundos, apresentam granulometria com dominância de silte-argila, alto conteúdo de sal e sulfeto de hidrogênio $\left(\mathrm{H}_{2} \mathrm{~S}\right)$, baixa consistência, pH ácido, coloração variando de negro a cinza-escuro, e odor característico, devido à grande quantidade de matéria orgânica em decomposição (DAVIS et al., 2003; FERREIRA et al., 2010; REEF et al., 2010).

Um dos processos biogeoquímicos de grande importância nos manguezais é a redução bacteriana do sulfato e consequente piritização (CURY, 2006). A reduzida difusão de $\mathrm{O}_{2}$ devido à saturação do solo com água faz com que a matéria orgânica passe a ser degradada por bactérias que irão utilizar receptores de elétrons alternativos na seguinte sequência termodinâmica: $\mathrm{NO}_{3}{ }^{-}>\mathrm{MN}^{4+}>\mathrm{Fe}^{3+}>\mathrm{SO}_{4}{ }^{2-}>\mathrm{CO}_{2}>\mathrm{N}_{2}>\mathrm{H}^{+}$(FROELICH et al., 1979; HILL, 1982). A abundância de $\mathrm{SO}_{4}{ }^{2-}$ e $\mathrm{Fe}^{3}$ nos solos de mangue faz com que estes sejam utilizados e reduzidos a sulfeto e $\mathrm{Fe}^{2+}$, que combinados podem formar a pirita $\left(\mathrm{FeS}_{2}\right)$, um mineral estável nestas condições. Na ausência de $\mathrm{Fe}^{2+}$ o sulfeto produzido pode se difundir para as camadas mais superficiais do solo, onde a difusão de $\mathrm{O}_{2}$ é maior, e ser re-oxidado a sulfato, fechandose assim um ciclo biogeoquímico (ZOPFI et al., 2001). 
Os organismos presentes nos solos dos manguezais estão adaptados às condições de flutuações de salinidade, altas temperaturas, ventos fortes, baixos teores de oxigênio e alternância de inundações derivadas das marés (BLASCO et al., 1996; KATHIRESAN \& BINGHAM, 2001). Vale ressaltar que as comunidades microbianas diversificadas e altamente produtivas encontradas nos sedimentos de manguezais têm papel fundamental na manutenção da produtividade, conservação e recuperação destes ecossistemas (HOLGUIN et al., 2001). Elas estão diretamente envolvidas na transformação bioquímica dos nutrientes e da matéria orgânica, fotossíntese, fixação do nitrogênio, metanogênese, solubilidade do fosfato, redução do sulfato e produção de inúmeros metabólitos secundários, incluindo antibióticos, biosurfactantes e enzimas envolvidas na degradação de compostos contaminantes, funcionando como importantes reservatórios de produtos de interesse biotecnológico (ALSAYED et al., 2005; ALONGI, 2002; HONG et al., 2009; SANTOS et al., 2011b).

Nos últimos anos vários esforços têm sido desenvolvidos para caracterizar a comunidade procariótica presente em manguezais do Brasil. Dentre os trabalhos mais significativos cita-se o realizado por Brito et al. (2009; 2006) que caracterizaram a comunidade bacteriana hidrocarbonoclástica do manguezal da Baía de Guanabara (RJ). Posteriormente, nesta mesma região, Gomes e colaboradores (2007; 2008) caracterizaram a comunidade microbiana total, além de avaliar a diversidade do gene ndo (naftaleno dioxigenase) naquele ambiente. Já Paes (2008) realizou um estudo sobre a comunidade microbiana de áreas preservada e contaminada com petróleo na Baía de todos os Santos (BA), enquanto, no mesmo ambiente, Taketani e colaboradores (2010a) avaliaram a resposta da comunidade microbiana a uma simulação de derramamento de petróleo e Peixoto et al. (2011) verificaram os perfis microbianos com relação à variação espacial nos níveis de poluentes. Já Santos et al. (2011b) utilizaram amostras de uma área preservada da Restinga da Marambaia (RJ) para verificar as alterações sofridas pela comunidade bacteriana submetida a uma simulação de derramamento de petróleo.

Importantes trabalhos também foram realizados nos manguezais do Estado de São Paulo, onde Taketani e colaboradores (2010b) conduziram um estudo para identificação e análise da diversidade de arqueias metanogênicas e bactérias redutoras de sulfato no manguezal de Cananéia enquanto Dias et al. (2010) caracterizaram a comunidade bacteriana e também realizaram um estudo sobre a diversidade da comunidade de arqueias nos manguezais de Cananéia e Bertioga (DIAS et al., 2011) e, além destes trabalhos, Andreote et al. (2012) recentemente utilizaram uma abordagem metagenômica para análise do microbioma dos manguezais de Cananéia e Bertioga. 
Sabe-se que os manguezais, devido a sua posição ao longo da linha costeira, sofrem com impactos associados às atividades das civilizações, tais como deposição de lixo, lançamento de esgotos, efluentes industriais, atividades portuárias, pesqueiras, exploração mineral e petroquímica (JACOBI et al., 1990; KATHIRESAN \& BINGHAM, 2001; LEE et al., 2006). Estes ambientes são expostos a derramamentos contínuos e/ou acidentais de petróleo, sendo considerados os ecossistemas mais sensíveis e vulneráveis aos efeitos deste poluente, o que causa impactos consideráveis, inclusive sobre a comunidade microbiana (BRITO et al., 2009; GOMES et al., 2008), o que tem tornado esses ambientes um dos mais estudados com relação aos impactos causados pelos derramamentos e vazamentos de petróleo.

A descarga total de óleo cru e seus subprodutos no ambiente marinho é estimada em 1,7 a 8,8 milhões de toneladas por ano, ocorrendo principalmente nas zonas de produção e por perdas no transporte do petróleo (KE et al., 2002). As altas concentrações de matéria orgânica, o caráter anóxico, a proximidade das fontes poluidoras, a posição em relação ao corpo d’água e o regime das marés favorecem a permanência e o acúmulo de derivados de petróleo nos solos dos manguezais (KATHIRESAN \& BINGHAM, 2001; REYES, 2009). Esses compostos podem persistir por mais de 20 anos e, em longo prazo, causar desequilíbrio nos processos essenciais para a manutenção do ambiente, incluindo modificações nos ciclos biogeoquímicos e na cadeia alimentar (GOMES et al., 2008; HOLGUIN et al., 2001; TAM et al., 2005).

O manguezal é considerado um recurso renovável, porém finito, quando se leva em conta a produção natural de peixes, ostras, caranguejos, camarões, siris, mariscos e até mel. Porém, passa a ser considerado um recurso não renovável quando são substituídos por outros usos do solo, ou ainda por atividades que os transformam em depositários de efluentes, lixo e o extrativismo indiscriminado (SCHAEFFER-NOVELLI, 2000).

Estudos demonstram uma perda das áreas dos manguezais em torno de 1 a $2 \%$ ao ano, indicando uma tendência ao desaparecimento desses ecossistemas, dado o grau de impacto sofrido nos últimos anos e considerando que um período mínimo de 20 anos é necessário para recuperação total de áreas de manguezais impactadas por derramamento de petróleo (BURNS et al., 1993; DUKE et al., 2007; LEE et al., 2006).

\subsection{Manguezais de São Paulo - Áreas de Estudo}

O litoral do Estado de São Paulo possui 622 quilômetros de extensão e apresenta quatro subunidades geográficas bem individualizadas: Litoral Norte, Baixada Santista, Complexo 
Estuarino-Lagunar Iguape-Cananéia e Vale do Ribeira (CUNHA-LIGNON et al., 2009b). Nesse estado os manguezais ocupam uma área aproximada de $231 \mathrm{~km}^{2}$, sendo que o Complexo Lagunar Iguape-Cananéia (108 $\mathrm{Km}^{2}$ de manguezais) e a planície costeira da Baixada Santista (120 $\mathrm{Km}^{2}$ de manguezais) formam as maiores áreas (CUNHA-LIGNON et al., 2009a; LAMPARELLI et al., 1999). Nosso estudo foi conduzido em três desses manguezais, sendo um deles localizado na cidade de Cananéia (Complexo Estuarino-Lagunar Iguape-Cananéia) e os dois outros na cidade de Bertioga (Baixada Santista).

O manguezal da cidade de Cananéia encontra-se em uma área de Reserva Ambiental e foi utilizado neste estudo como uma área de referência, enquanto os manguezais de Bertioga: (i) um está próximo à área urbana e apresenta efeito de contaminação antrópica, recebendo resíduos industriais e esgoto doméstico e (ii) o outro sofreu uma contaminação por derramamento de petróleo. A sistemática de inundação dos manguezais também apresenta diferenças, pois naqueles localizados em Bertioga a água de inundação é composta por uma mistura entre a água do Rio Iriri e a água do mar, enquanto que no manguezal de Cananéia a inundação é baseada no recebimento apenas de água do mar (DIAS et al., 2011), conforme apresentado na Figura 2.

Com relação à vegetação esses manguezais também apresentam diferenças entre si. No manguezal de Bertioga que sofreu derramamento de petróleo, o ponto próximo ao mar é dominado pela espécie Rhizophora mangle enquanto que nos pontos localizados na floresta de manguezal e na restinga (locais específicos do derramamento) a espécie Laguncularia racemosa mostrou-se mais resistente ao impacto. No manguezal de Bertioga que sofre com ação antrópica as espécies comumente encontradas são $R$. mangle, L. racemosa e Aviccenia sp. No manguezal de Cananéia, as espécies $R$. mangle, L. racemosa e Aviccenia shaueriana estão distribuídas uniformemente em todo o transecto, mostrando que o ambiente se mantém preservado e com sua estrutura vegetal natural (DIAS, 2012).

O sistema Iguape-Cananéia localiza-se no extremo sul do litoral do Estado, entre as latitudes $24^{\circ} 40^{\prime} \mathrm{S}$ e $25^{\circ} 20^{\prime} \mathrm{S}$ com temperatura média anual de $21,4^{\circ} \mathrm{C}$ e precipitação média anual de 2.700 mm (CUNHA-LIGNON et al., 2011a; SCHAEFFER-NOVELLI et al., 1990b). O manguezal da Ilha do Cardoso situa-se na cidade de Cananéia e, devido à riqueza de seu ecossistema, é uma região protegida pelo Governo do Estado através da criação do Parque Estadual da Ilha do Cardoso em 1.962, considerado Patrimônio Mundial pela UNESCO desde 1.999 (CUNHA-LIGNON et al., 2011b). Sua população é formada por caiçaras que vivem da pesca e da cultura de subsistência (ALMEIDA, 2005). 
Figura 2. Fotos dos manguezais de Bertioga e Cananéia (Ilha do Cardoso).
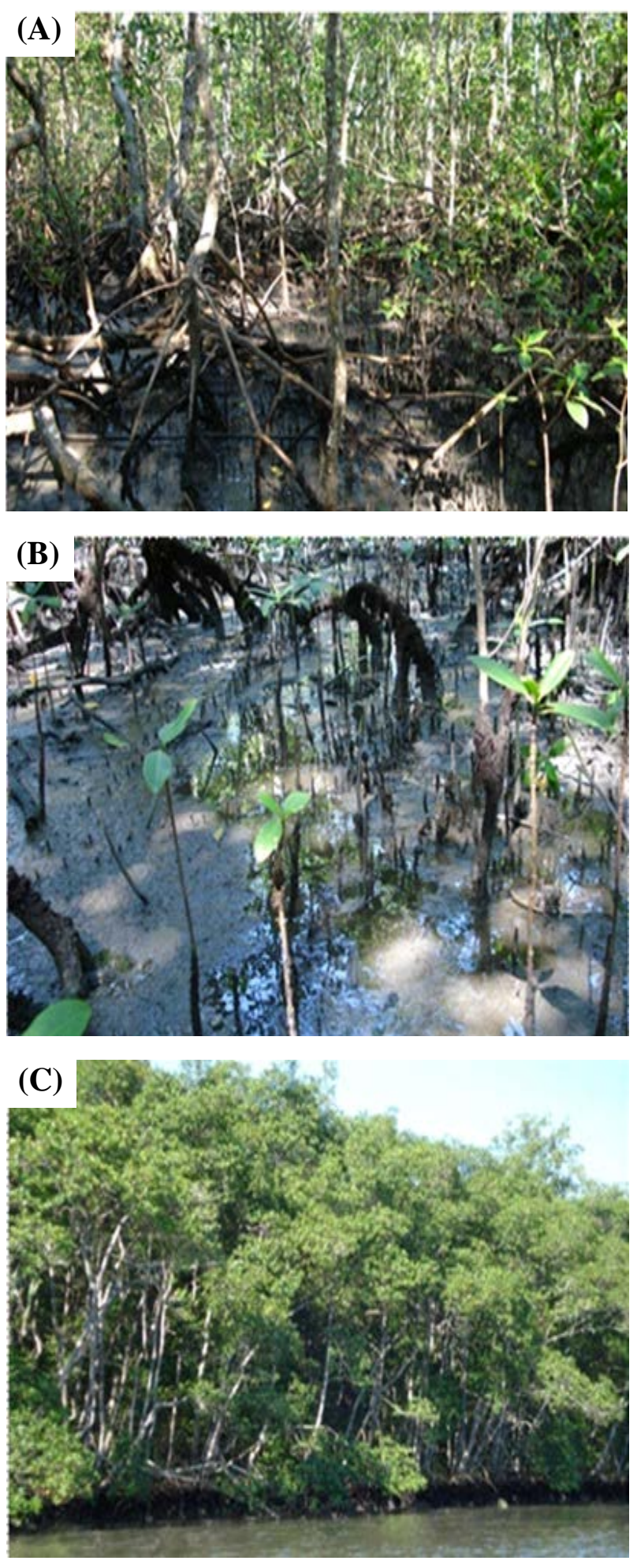

(A) manguezal de Bertioga com contaminação antrópica; (B) manguezal de Bertioga que sofreu derramamento de óleo em 1.983; (C) manguezal da Ilha do Cardoso - Cananéia.

Fotos cedidas por Armando Dias (DIAS, 2012).

A Baixada Santista localiza-se no litoral central do Estado, entre as latitudes 2450'S e 2345’S e abrange os municípios de Bertioga, Cubatão, Itanhaém, Mongaguá, Peruíbe, Praia Grande, Santos e São Vicente, com temperatura média anual de $22{ }^{\circ} \mathrm{C}$ e precipitação média 
anual entre 2.000 a 2.500 mm (LAMPARELLI \& MOURA, 1999; MENGHINI et al., 2011; PRADA-GAMERO et al., 2004).

Na região da Baixada Santista é reconhecida a contaminação por organoclorados e hidrocarbonetos entre outros compostos poluentes. De maneira geral, a Baixada Santista é uma região de grande interesse econômico, onde se encontra o maior polo petroquímico e de fertilizantes do país, um importante centro mineralo-metalúrgico e um dos maiores centros portuários do mundo (BONETTI, 2000; DAVID, 1997). Em virtude do grande desenvolvimento urbano e industrial da região, são várias as fontes de descaracterização ambiental. Cita-se a rápida expansão da taxa de urbanização, sobretudo próximo à orla, levando à utilização de áreas inadequadas ao assentamento urbano, como os Manguezais (BONETTI, 2000), além das consequências advindas dos derrames e vazamentos de petróleo na região. O Quadro 1 apresenta as principais ocorrências envolvendo derramamentos e vazamentos de petróleo e derivados no Estado de São Paulo de 1.974 a 2.012.

Um evento de grandes proporções ocorreu em 14 de outubro de 1.983, em que o rompimento de um trecho do tronco do oleoduto da PETROBRÁS (Petróleo Brasileiro S.A), que liga o Terminal Marítimo Almirante Barroso (TEBAR) à Refinaria Presidente Bernardes de Cubatão, provocou a liberação de 3.000.000 de litros de petróleo que desceram pelo Rio Iriri até atingir o Canal de Bertioga, espalhando-se por cerca de 60 quilômetros e causando um desastre ambiental na área de manguezal ali presente (COIMBRA, 2006).

A Baixada Santista sofre também os impactos de outras fontes poluidoras, tais como esgotos domésticos e municipais lançados in natura nas águas costeiras; disposição de resíduos sólidos nas áreas de manguezais; desmatamento dos manguezais, provocando assoreamento das áreas marginais; atividades de dragagem dos canais de navegação, que aumentam a turbidez das águas; construção de marinas, além dos derrames industriais (MEDEIROS et al., 2004; PINTO, 2003).

Apesar dos esforços da CETESB (Companhia de Tecnologia e Saneamento Ambiental) no sentido de evitar novos lançamentos de efluentes contaminados no estuário, compostos recalcitrantes e tóxicos, incluindo Hidrocarbonetos Policíclicos Aromáticos (HPAs), bifenilos policlorados e metais pesados ainda são detectados em amostras de sedimento do estuário de Santos e São Vicente (ABESSA, 2002; FRAZÃO, 2001; MEDEIROS, 2000; RACHID, 2002). Em um estudo conduzido no Estuário de Santos houve a detecção de altos níveis de hidrocarbonetos policíclicos aromáticos e alifáticos em amostras de sedimento, sendo que a principal origem destes contaminantes foi considerada antropogênica (NISHIGIMA et al., 2001). 
Quadro 1. Ocorrências envolvendo derramamentos e vazamentos de petróleo e derivados no Estado de São Paulo (1974 - 2012).

\begin{tabular}{|c|c|c|c|}
\hline Fonte/Causa & Data & Local/ áreas atingidas & $\begin{array}{c}\text { Volume vazado } \\
\text { estimado }\end{array}$ \\
\hline $\begin{array}{l}\text { Transporte marítimo / colisão do } \\
\text { navio Takimyia Maru com rocha }\end{array}$ & Ago/1974 & $\begin{array}{l}\text { Canal de São Sebastião (SP) /praias } \\
\text { e costões de Ubatuba. }\end{array}$ & $\begin{array}{l}6.000 \mathrm{~m}^{3} \text { de } \\
\text { petróleo }\end{array}$ \\
\hline 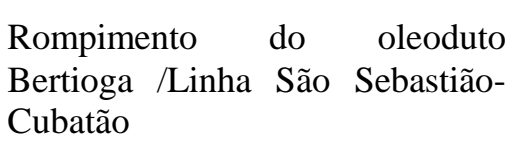 & Out/1983 & $\begin{array}{c}\text { Canal de Bertioga (SP) /mangue, } \\
\text { praias e costões. }\end{array}$ & $\begin{array}{l}3.000 \mathrm{~m}^{3} \mathrm{de} \\
\text { petróleo }\end{array}$ \\
\hline $\begin{array}{l}\text { Rompimento do oleoduto Vila } \\
\text { Socó /Linha Cubatão -Santos }\end{array}$ & Fev/1984 & $\begin{array}{c}\text { Cubatão (SP)/ mangue, mortos e } \\
\text { feridos. }\end{array}$ & $\begin{array}{l}\text { Não estimado de } \\
\text { gasolina }\end{array}$ \\
\hline $\begin{array}{l}\text { Terminal de armazenamento } \\
\text { /Incêndio no córrego do Outeiro }\end{array}$ & Jun/1984 & $\begin{array}{l}\text { Centro urbano de São Sebastião/ } \\
\text { praias - um óbito. }\end{array}$ & Não estimado \\
\hline $\begin{array}{l}\text { Transporte marítimo /colisão do } \\
\text { navio Marina com píer do } \\
\text { terminal }\end{array}$ & Mar/1985 & $\begin{array}{l}\text { São Sebastião (SP) /praias e costões } \\
\text { litoral norte. }\end{array}$ & $\begin{array}{l}2.500 \mathrm{~m}^{3} \mathrm{de} \\
\text { petróleo }\end{array}$ \\
\hline $\begin{array}{l}\text { Refinaria de Cubatão /Explosão } \\
\text { em tanque de armazenamento }\end{array}$ & Jul/1985 & Cubatão (SP) /Rio Cubatão. & $\begin{array}{l}500 \mathrm{~m}^{3} \text { de óleo } \\
\text { combustível }\end{array}$ \\
\hline $\begin{array}{l}\text { Rompimento de oleoduto / linha } \\
\text { São Sebastião-Cubatão }\end{array}$ & Mai/1994 & $\begin{array}{l}\text { São Sebastião (SP) / vegetação, } \\
\text { praias e costões. }\end{array}$ & $\begin{array}{l}2.700 \mathrm{~m}^{3} \text { de } \\
\text { petróleo }\end{array}$ \\
\hline $\begin{array}{l}\text { Transporte marítimo / Colisão } \\
\text { entre navios Smyrni e Elizabeth } \\
\text { Rickmers }\end{array}$ & Jul/1998 & Porto de Santos. & $\begin{array}{l}40 \mathrm{~m}^{3} \text { de bunker } \\
\text { MF } 180\end{array}$ \\
\hline $\begin{array}{l}\text { Transporte marítimo / Explosão } \\
\text { do navio Alina P. }\end{array}$ & Dez/2001 & Canal de São Sebastião /um óbito. & Não estimado \\
\hline $\begin{array}{l}\text { Transporte marítimo / Navio } \\
\text { Nortic Marita no Canal de São } \\
\text { Sebastião }\end{array}$ & Jun/2003 & $\begin{array}{l}\text { São Sebastião a Ubatuba /praias, } \\
\text { costões, mangue e lagoa costeira. }\end{array}$ & $\begin{array}{l}25 \mathrm{~m}^{3} \mathrm{de} \\
\text { petróleo }\end{array}$ \\
\hline $\begin{array}{l}\text { Rompimento de oleoduto / Linha } \\
\text { São Sebastião- Cubatão }\end{array}$ & Fev/2004 & $\begin{array}{l}\text { Guaecá - São Sebastião (SP)/ } \\
\text { vegetação, rio, praia. }\end{array}$ & $\begin{array}{l}300 \mathrm{~m}^{3} \text { de } \\
\text { petróleo }\end{array}$ \\
\hline $\begin{array}{l}\text { Exploração e produção de } \\
\text { petróleo /Plataforma de Mexilhão } \\
\text { - falha na movimentação interna } \\
\text { de diesel }\end{array}$ & Ago/2010 & $\begin{array}{c}\text { Bacia de Santos /Poluição em alto } \\
\text { mar. }\end{array}$ & $\begin{array}{l}50 \text { L de óleo } \\
\text { diesel }\end{array}$ \\
\hline $\begin{array}{l}\text { Refinaria / extravasamento de } \\
\text { tanque de resíduo oleoso }\end{array}$ & Jan/2011 & $\begin{array}{c}\text { Cubatão (SP) / contaminação do } \\
\text { Rio Cubatão. }\end{array}$ & Não estimado \\
\hline $\begin{array}{llr}\text { Exploração e produção de } \\
\text { petróleo /Navio } & \text { Plataforma } \\
\text { Dynamic Producer } & - & \text { Campo } \\
\text { Carioca Nordeste } & \end{array}$ & Jan/2012 & $\begin{array}{c}\text { Bacia de Santos / teste de longa } \\
\text { duração Pré-sal } 253 \text { km do litoral } \\
\text { norte de São Paulo }\end{array}$ & $\begin{array}{l}26 \mathrm{~m}^{3} \mathrm{de} \\
\text { petróleo }\end{array}$ \\
\hline
\end{tabular}




\subsection{Petróleo e Hidrocarbonetos Aromáticos}

O petróleo é definido como uma mistura de diferentes compostos de ocorrência natural e cuja composição química é bastante complexa, altamente variável e extremamente influenciada pelas condições ambientais em que foi formado, incluindo características físicoquímicas, biológicas e geológicas (VAN HAMME et al., 2003). O petróleo é constituído, predominantemente por hidrocarbonetos, que podem chegar a 97\% de sua composição e, em menor quantidade, de derivados orgânicos sulfurados, nitrogenados, oxigenados e organometálicos (ATLAS, 1981; ATLAS, 1995; MAIR et al., 1936; POSTHUMA, 1977; SANTOS et al., 2011a). Devido à predominância dos hidrocarbonetos no petróleo, esses são os compostos mais utilizados como indicadores deste tipo de poluição.

Os hidrocarbonetos configuram uma classe de compostos orgânicos que estão amplamente distribuídos na natureza e são formados principalmente por carbono e hidrogênio, aos quais pode se juntar átomos de oxigênio, nitrogênio e enxofre (CHADHAIN et al., 2006). Em função de sua estrutura molecular os hidrocarbonetos classificam-se em cíclicos ou alifáticos/saturados (alcanos, alcenos e alcinos), aromáticos (benzênicos e policíclicos) e compostos polares (resinas e asfaltenos) (YENDER et al., 2002). De acordo com sua origem os hidrocarbonetos podem ser denominados biogênicos - presentes na constituição da matéria orgânica de origem vegetal e animal; petrogênicos - constituintes do petróleo e seus subprodutos; ou pirogênicos - produzidos por combustão de matéria orgânica ou combustível fóssil (DAS et al., 2011; FOGHT, 2008; LOZADA et al., 2008; SEO et al., 2009). Os principais hidrocarbonetos aromáticos podem ser observados na Figura 3.

A NBR 10.004 da Associação Brasileira de Normas Técncias - ABNT (2004) classifica os resíduos sólidos quanto aos seus riscos potenciais ao meio ambiente e à saúde pública. Nos anexos B (resíduos perigosos de fontes específicas) e C (substâncias que conferem periculosidade aos resíduos) desta listagem estão incluídos diversos hidrocarbonetos aromáticos considerados tóxicos como o benzeno, tolueno, naftaleno, bifenilo policlorado, fluoranteno, benzo(a)antraceno, criseno, benzo(b)fluoranteno, benzo(j)fluoranteno, benzo(k)fluoranteno, benzo(a)pireno, dimetilbenzo(a)antraceno, indeno(1,2,3-c,d)pireno, dibenzo(a,h)antraceno e dibenzo(a,i)pireno. Segundo esta NBR a presença de um desses compostos no resíduo é suficiente para classificá-lo como resíduo perigoso (classe I), o que implica em necessidade de formas adequadas de gerenciamento para evitar que ocorra contaminação ambiental e humana. 
Figura 3. Estrutura dos principais hidrocarbonetos aromáticos.

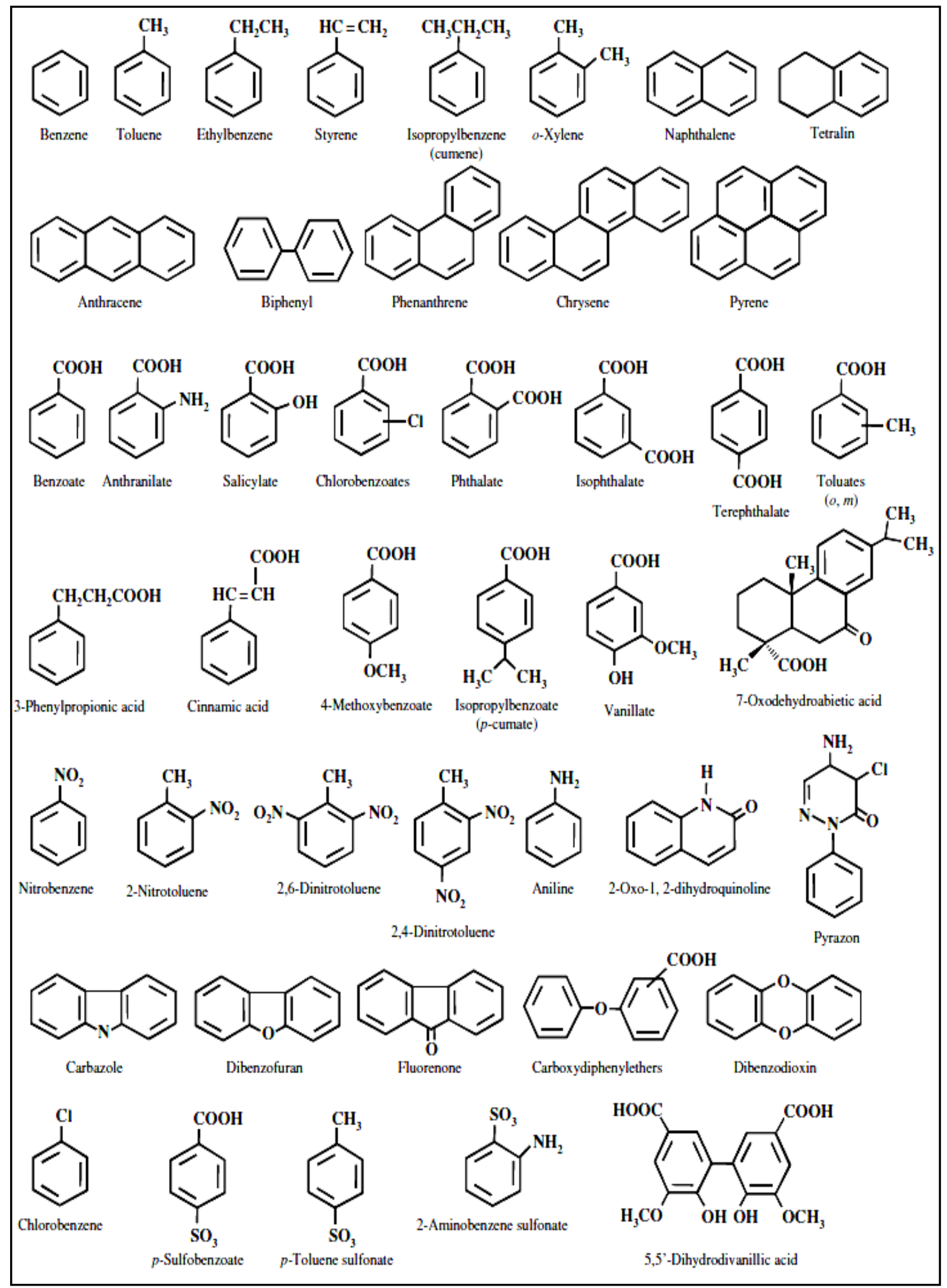

Fonte: Parales et al. (2006) 
Os hidrocarbonetos aromáticos simples são constituídos por um único anel benzênico e os representantes mais conhecidos incluem a classe BTEX que se refere ao benzeno, tolueno, etilbenzeno e xileno, produzidos em grande quantidade na forma de reagentes químicos para uso industrial, tais como solventes e precursores na produção de pesticidas, plásticos e fibras sintéticas. São contaminantes comuns do solo e reconhecidos como poluentes prioritários pela USEPA (US Environmental Protection Agency) (ANDREONI et al., 2007; HERRMANN et al., 2010; LIOU et al., 2008; LUO et al., 2009; WITZIG et al., 2006).

Os Hidrocarbonetos Policíclicos Aromáticos (HPAs) são uma classe de compostos orgânicos hidrofóbicos constituídos por ligações duplas e simples que se alternam com no mínimo dois anéis benzênicos arranjados em formas lineares, angulares ou em grupos (ANTIZAR-LADISLAO et al., 2004; DYKE et al., 2003; PENG et al., 2008).

As propriedades físicas e químicas dos HPAs, tais como reatividade química, solubilidade e volatilidade variam de acordo com o seu peso molecular e número de anéis benzênicos, mas de forma geral esses compostos são hidrofóbicos, termodinamicamente estáveis e recalcitrantes, apresentam baixa solubilidade e aderem fortemente a partículas suspensas e material particulado, permanecendo por anos em solos e sedimentos (SEO et al., 2009; SOCLO et al., 2000; ZENG et al., 2000).

Com base em suas propriedades e peso molecular os HPAs podem ser classificados em duas classes: (I) os de baixo peso molecular, com dois a três anéis benzênicos (naftaleno, bifenilo, acenaftileno, acenafteno, fluoreno, dibenzotiofeno, fenantreno e antraceno) e (II) os de alto peso molecular, com quatro a seis anéis aromáticos (fluoranteno, pireno, benzo(a)antraceno, criseno, benzo(b)fluoranteno, benzo(k)fluoranteno, benzo(e)pireno, benzo(a)pireno, indeno[1,2,3-cd]pireno, dibenzo(a,h)antraceno, benzo(g,h,i)pirileno) (TAM et al., 2001).

Em resíduos sólidos a presença de HPAs é de grande interesse, uma vez que pode ocorrer contaminação humana direta - por contato com o resíduo (no manuseio, no tratamento ou na disposição) ou indireta - causada pelo destino final inadequado dos resíduos e consequente contaminação ambiental do solo, lençol freático, corpos d’água superficiais, biota e ar (SISINNO et al., 2003).

Os HPAs antropogênicos são considerados contaminantes ambientais persistentes e podem se dispersar no ambiente como resultado de atividade de exploração, produção e transporte de petróleo, operações de carga e descarga em terminais petrolíferos, acidentes com petroleiros, efluentes domésticos e industriais, queima de florestas e combustão parcial de 
combustíveis em transportes, aquecimento e geração de energia (BAMFORTH et al., 2005; BRANDT et al., 2002; DAS \& CHANDRAN, 2011; MILLE et al., 2007; TAM et al., 2001).

Os HPAs são lipossolúveis e prontamente absorvidos na membrana celular dos humanos via inalação, exposição cutânea e alimentação, especialmente pelo consumo de peixes e frutos do mar, com posterior acúmulo no tecido adiposo (BAMFORTH \& SINGLETON, 2005; FERNANDES et al., 2002). O metabolismo de HPAs, especialmente daqueles de alto peso molecular, gera compostos tóxicos, mutagênicos e carcinogênicos para os organismos vivos, tendo sido relatados casos de câncer de pulmão, intestino, fígado, pâncreas e pele, devido ao contato com esses compostos (BRANDT et al., 2002; BRENNER et al., 2002; LEI et al., 2007; LOZADA et al., 2008; YU, 2002). O Quadro 2 apresenta um resumo dos principais HPAs considerados tóxicos pela ABNT (2004) ou relacionados como carcinogênicos pela International Agency for Research on Cancer (2010) e US Environmental Protection Agency (2009).

O naftaleno é um dos HPAs mais simples, composto por dois anéis benzênicos, de fórmula química $\mathrm{C}_{10} \mathrm{H}_{8}$, comercialmente denominado naftalina, apresentando odor característico e uma distribuição global (HABE et al., 2003). É uma substância inflamável, carcinogênica e tem sido usada como modelo no estudo da degradação de HPAs por ser facilmente degradada por micro-organismos e por apresentar relativamente alta solubilidade quando comprado aos demais HPAs. A exposição constante a esta substância por inalação, ingestão ou contato dérmico pode causar danos ao sistema nervoso, problemas no fígado, anemia hemolítica, danos à retina, catarata e câncer (AHN et al., 1999; GRIMM et al., 1997).

Dibenzofuranos são compostos aromáticos com dois anéis benzênicos unidos por um anel furano. Apresentam fórmula química $\mathrm{C}_{12} \mathrm{H}_{8} \mathrm{O}$, são semi-voláteis e exibem toxicidade para mamíferos (ZHANG et al., 2009). Como um dos poluentes orgânicos persistentes mais tóxicos já conhecidos estes compostos têm atraído a atenção nos últimos anos (BA et al., 2009; WU, Y.-L. et al., 2009). Dibenzofuranos são formados e liberados como bioprodutos de atividades humanas como a combustão de óleo, incineração de lixo, clareamento de celulose e papel, produção de pesticidas e no processo de queima da madeira (CHENG et al., 2010; DYKE et al., 1997).

Embora a exposição de humanos aos dibenzofuranos possa ocorrer por várias rotas, estudos têm reportado a alimentação como a fonte primária (LLOBET et al., 2003). A exposição aos dibenzofuranos tem sido associada a uma ampla taxa de efeitos adversos em animais e humanos, tais como: sarcomas, linfomas, lesões de pele, câncer de estômago, 
anormalidades no fígado, além de alterações no sistema nervoso e imunológico (KULKARNI et al., 2008).

Quadro 2. Principais Hidrocarbonetos Policíclicos Aromáticos reportados em análises químicas e estudados quanto a sua carcinogenicidade, ocorrência e toxicidade

\begin{tabular}{|lccccc|}
\hline \multicolumn{1}{|c}{ HPA } & $\begin{array}{c}\text { Número de } \\
\text { Anéis } \\
\text { Benzênicos }\end{array}$ & $\begin{array}{c}\text { Fórmula } \\
\text { Química }\end{array}$ & IARC & US EPA & ABNT \\
\hline Naftaleno & 2 & $\mathrm{C}_{10} \mathrm{H}_{8}$ & $2 \mathrm{~B}$ & $\mathrm{P}$ & $\mathrm{T}$ \\
Bifenilo policlorado & 2 & $\mathrm{C}_{2} \mathrm{H}_{10-\mathrm{n}} \mathrm{Cl}_{n}$ & $2 \mathrm{~A}$ & $\mathrm{P}$ & $\mathrm{T}$ \\
Fluoreno & 2 & $\mathrm{C}_{13} \mathrm{H}_{10}$ & 3 & $\mathrm{P}$ & $\mathrm{NM}$ \\
Antraceno & 3 & $\mathrm{C}_{14} \mathrm{H}_{10}$ & 3 & $\mathrm{P}$ & $\mathrm{T}$ \\
Fenantreno & 3 & $\mathrm{C}_{14} \mathrm{H}_{10}$ & 3 & $\mathrm{P}$ & $\mathrm{NM}$ \\
Benzo(a)antraceno & 4 & $\mathrm{C}_{18} \mathrm{H}_{12}$ & $2 \mathrm{~A}$ & $\mathrm{P}$ & $\mathrm{T}$ \\
Criseno & 4 & $\mathrm{C}_{18} \mathrm{H}_{12}$ & 3 & $\mathrm{P}$ & $\mathrm{T}$ \\
Fluoranteno & 4 & $\mathrm{C}_{16} \mathrm{H}_{10}$ & 3 & $\mathrm{P}$ & $\mathrm{T}$ \\
Pireno & 4 & $\mathrm{C}_{16} \mathrm{H}_{10}$ & 3 & $\mathrm{P}$ & $\mathrm{T}$ \\
Benzo(a)pireno & 5 & $\mathrm{C}_{20} \mathrm{H}_{12}$ & $2 \mathrm{~A}$ & $\mathrm{P}$ & $\mathrm{T}$ \\
Benzo(b)fluoranteno & 5 & $\mathrm{C}_{20} \mathrm{H}_{12}$ & $2 \mathrm{~B}$ & $\mathrm{P}$ & $\mathrm{T}$ \\
Benzo(e)pireno & 5 & $\mathrm{C}_{20} \mathrm{H}_{12}$ & 3 & $\mathrm{P}$ & $\mathrm{NM}$ \\
Benzo(k)fluoranteno & 5 & $\mathrm{C}_{20} \mathrm{H}_{12}$ & $2 \mathrm{~B}$ & $\mathrm{P}$ & $\mathrm{T}$ \\
Dibenzo(a,h)antraceno & 5 & $\mathrm{C}_{20} \mathrm{H}_{12}$ & $2 \mathrm{~A}$ & $\mathrm{P}$ & $\mathrm{T}$ \\
Indeno[1,2,3-c,d]pireno & 5 & $\mathrm{C}_{22} \mathrm{H}_{12}$ & $2 \mathrm{~B}$ & $\mathrm{P}$ & $\mathrm{T}$ \\
Benzo(g,h,i)perileno & 6 & $\mathrm{C}_{22} \mathrm{H}_{12}$ & 3 & $\mathrm{P}$ & $\mathrm{NM}$ \\
Coroneno & 6 & $\mathrm{C}_{24} \mathrm{H}_{12}$ & 3 & $\mathrm{P}$ & $\mathrm{NM}$ \\
\hline
\end{tabular}

2A = Provável Carcinogênico para humanos, 2B= Possível carcinogênico para humanos, 3 = Não é classificado como carcinogênico para humanos. $\mathrm{P}=$ prioritário. $\mathrm{T}$ = tóxico, $\mathrm{NM}=$ não mencionado.

Fonte: Adaptado de ABNT (2004), IARC (2010) e US EPA (2009).

Os bifenilos $\left(\mathrm{C}_{12} \mathrm{H}_{10}\right)$ são moléculas compostas por dois anéis benzênicos ligados entre si por uma ligação simples no Carbono 1. Os bifenilos policlorados são hidrocarbonetos aromáticos produzidos comercialmente pela cloração direta da molécula de bifenilo, processo que pode gerar até 209 compostos congêneres, representados pela fórmula $\mathrm{C}_{12} \mathrm{H}_{(10-n)} \mathrm{Cl}_{n}$ onde $n$ é o número de átomos de cloro que podem variar entre $1 \leq n \leq 10$ (ABRAHAM, 2002; FURUKAWA et al., 2008). Estes compostos são distribuídos globalmente e estão incluídos entre os principais Poluentes Orgânicos Persistentes (POPs), que são substâncias voláteis, bioacumulativas, persistentes e tóxicas (BREIVIK et al., 2004; BREIVIK et al., 2002b). A fórmula estrutural do bifenilo policlorado pode ser observada na Figura 4.

O sucesso tecnológico e a diversidade de uso dos bifenilos foram conferidos pelas suas notáveis propriedades químicas e físicas, dentre as quais se destacam a sua lipofilicidade, alta estabilidade química, resistência a temperaturas elevadas, alta constante dielétrica, baixa 
reatividade e volatilidade à temperatura ambiente e resistência à biodegradação (DE SOUZA et al., 2008). Em função de algumas dessas propriedades eles foram amplamente utilizados na indústria como fluídos isolantes em capacitores e transformadores, plastificantes, retardantes de chama; também foram usados na composição de graxas e óleos lubrificantes, tintas de impressão e pesticidas (FURUKAWA \& FUJIHARA, 2008; ROSS, 2004)

Figura 4. Fórmula estrutural do bifenilo policlorado

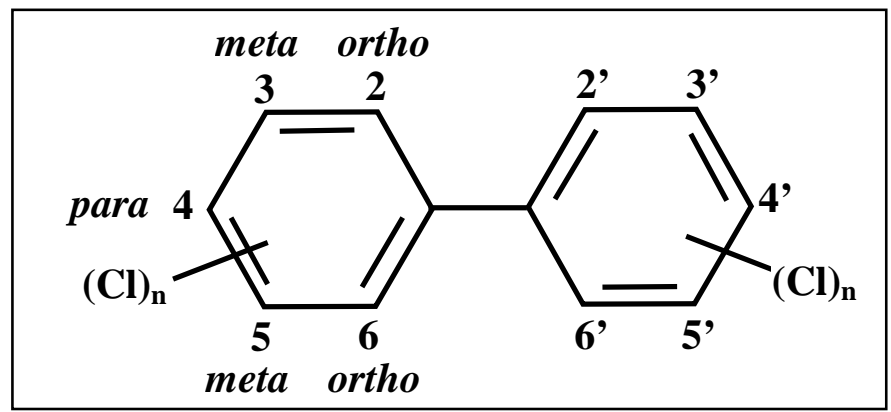

Fonte: Borja et al. (2005)

Não existem evidências que suportem a ocorrência natural de bifenilos policlorados na natureza, mas estes compostos foram produzidos e comercializados intensamente a partir de 1929 com vários nomes comerciais (Aroclor® é o mais conhecido), e apesar da proibição de sua produção em 1970, o descarte de equipamentos industriais que utilizaram estas substâncias faz com que sejam detectadas em concentrações altas nos mais diversos ambientes até os dias atuais (BORJA et al., 2005).

Por serem compostos voláteis, os bifenilos podem ser liberados na atmosfera e, assim, originar um processo cíclico de contaminação do ar, da água e do solo (BREIVIK et al., 2002a; BREIVIK et al., 2007). Vários estudos já foram conduzidos para demonstrar o impacto dos bifenilos na saúde humana (KIMBROUGH et al., 2003; KURATSUNE, 1982; LADEN et al., 2001; ROSS, 2004; WEIDERPASS et al., 2000).

Dentre os efeitos nocivos que estes compostos podem causar aos seres vivos cita-se a permanência ao longo da cadeia trófica por bioacúmulo no tecido adiposo, rápida absorção pelas mucosas (DE SOUZA et al., 2008; YAO et al., 2002), irritações na pele, nos olhos, câncer (KIMBROUGH et al., 2003; WEIDERPASS et al., 2000), alterações na produção de espermatozóides (GUO et al., 2000; HSU et al., 2003), alterações no sistema reprodutor e endócrino feminino (YANG et al., 2005), alterações no sistema nervoso (FAROON et al., 2000) e no desenvolvimento de crianças (GUO et al., 1995; KIMBROUGH et al., 2001), 
transferência placentária, levando a alterações no tamanho/peso dos fetos e nascimentos prematuros (FEIN et al., 1984; SCHWARTZ et al., 1983).

De forma geral os HPAs podem ser removidos do ambiente por volatilização, fotooxidação, oxidação química, bioacumulação, adsorção a partículas sólidas ou biodegradação, sendo este último baseado na diversidade e versatilidade enzimática dos micro-organismos. Trata-se de um processo barato e uma das estratégias mais promissoras no tratamento de áreas impactadas (KANALY et al., 2000a; KASAI et al., 2001; NOGALES et al., 2001; TAM et al., 2002; TIAN et al., 2008). O resultado final da biorremediação é a transformação de poluentes orgânicos em metabólitos inofensivos, menos tóxicos ou sua total mineralização até dióxido de carbono e água (SEMPLE et al., 2003; SEO et al., 2009).

\subsection{Bactérias Envolvidas na Biodegradação de Hidrocarbonetos}

A biodegradação de HPAs de alto peso molecular é um processo complexo cujo sucesso depende de vários fatores bióticos e abióticos, dentre eles a presença e atividade de microorganismos capazes de degradar o composto poluente, a toxicidade e disponibilidade do composto, suas propriedades físico-químicas (solubilidade, peso molecular, reatividade química, disponibilidade e concentração) e as variáveis ambientais (oxigênio dissolvido, pH, temperatura, nutrientes disponíveis e salinidade). Várias espécies microbianas com diferentes complexos enzimáticos podem ser requeridas para a co-degradação total de misturas complexas de hidrocarbonetos no ambiente (DAS \& CHANDRAN, 2011; SANTOS et al., 2011a; SEMPLE et al., 2003).

Devido ao crescimento rápido, versatilidade metabólica, plasticidade genética e adaptação a várias condições ambientais, diversas vias de degradação de hidrocarbonetos têm sido identificadas e descritas em diferentes bactérias, conforme demonstrado na Figura 5 (DÍAZ, 2004).

Vale ressaltar que bactérias degradadoras destes compostos vêm sendo isoladas desde 1.950, sendo representadas principalmente pelos gêneros Achromobacter, Acidovorans, Acinetobacter, Aeromonas, Agrobacterium, Alcaligenes, Arthrobacter, Bacillus, Beijemickia, Brevibacterium, Burkholderia, Chryseobacterium, Comamonas, Corynebacterium, Cycloclasticus, Flavobacterium, Gordonia, Janibacter, Marinobacter, Microbacterium, Moraxella, Mycobacterium, Micrococcus, Neptuomonas, Nocardia, Nocardoides, Paracoccus, Pasteurella, Polaromonas, Pseudomonas, Ralstonia, Rhodanobacter, 
Rhodococcus, Sphingomonas, Stenotrophomonas, Streptomyces, Terrabacter, Vibrio e Xanthomonas (JACQUES et al., 2005; MUTNURI et al., 2005; SEO et al., 2009).

Figura 5. Degradação de compostos aromáticos por micro-organismos aeróbios e anaeróbios, demonstrando os diferentes aceptores de elétrons na respiração.

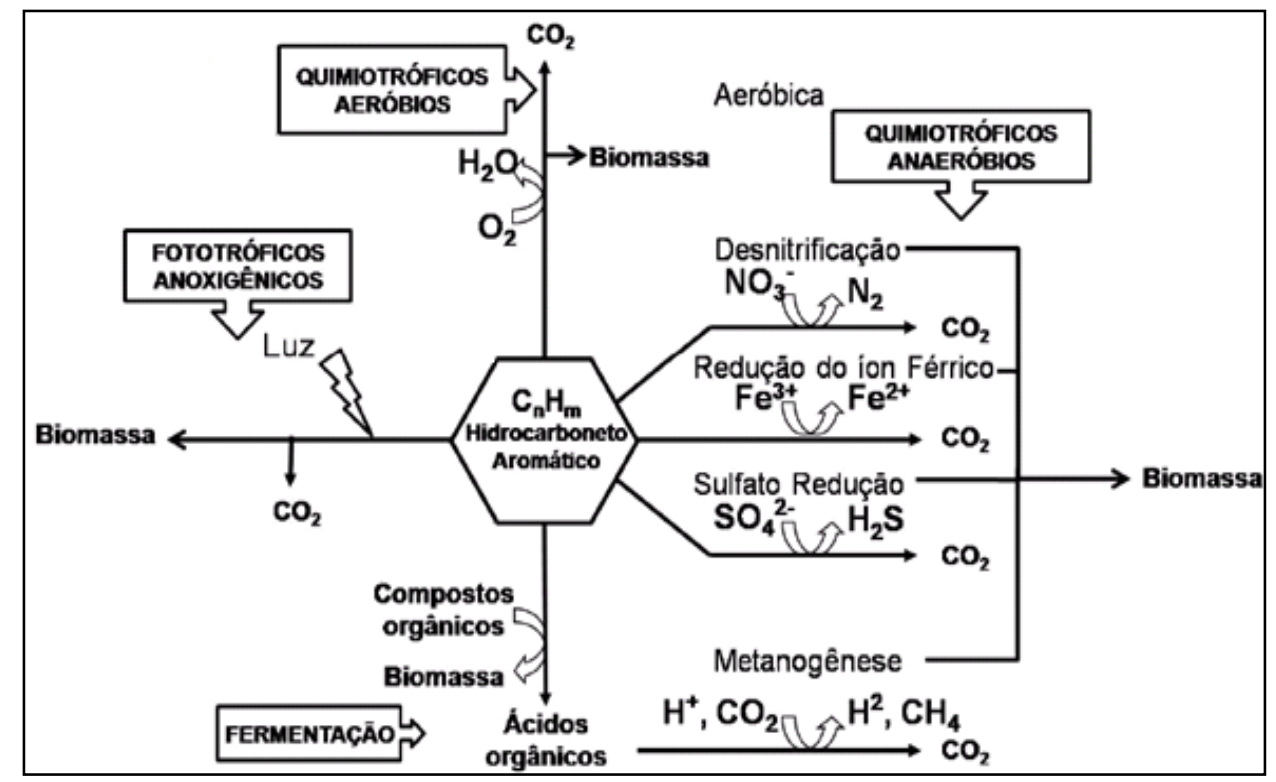

Fonte: Adaptado de Díaz (2004).

As vias bacterianas de degradação aeróbia de hidrocarbonetos aromáticos podem ser divididas em três etapas: (1) o composto aromático é transformado em um metabólito intermediário central da via de degradação dos HPAs, normalmente um catecol, através da introdução de grupos hidroxila por enzimas periféricas, com função de reconhecer as moléculas dos HPAs e convertê-las em intermediários centrais (BUGG et al., 1998; DÍAZ, 2004; KANALY et al., 2000b; WIDDEL et al., 2001); (2) as enzimas de fissão convertem os intermediários centrais em compostos que são utilizados nas vias comuns de geração de carbono e energia da bactéria. Ocorre a abertura do anel catecol por dioxigenases que catalisam a adição do oxigênio molecular ao anel. Esta abertura pode ocorrer em duas posições: entre os grupos hidroxila (clivagem intradiol e orto), ou adjacente a um dos grupos hidroxila (clivagem extradiol ou meta) (BUGG \& WINFIELD, 1998; DÍAZ, 2004; HEIDER et al., 1997; KANALY \& HARAYAMA, 2000b). As dioxigenases intradiol, possuem como cofator o $\mathrm{Fe}^{3+}$ e produzem o ácido cis-cis-mucônico. Enquanto as extradiol dioxigenases, dependem do $\mathrm{Fe}^{2+}$, produzindo o semialdeído 2- hidroximucônico e podem ser subdivididas em proximais e distais, para caracterizar a posição da clivagem do anel em relação ao radical 
(BUGG \& WINFIELD, 1998; DÍAZ, 2004; KANALY \& HARAYAMA, 2000b); (3) O produto resultante da abertura do anel é convertido em produtos que entram no cliclo de Krebs. O ácido cis-cis-murônico será convertido em succinato e acetil-Co-A e o semi-aldeído 2-hidroximucônico, será transformado em ácido pirúvico e acetaldeído (DÍAZ, 2004; KANALY \& HARAYAMA, 2000b).

Muitos ambientes contaminados por hidrocarbonetos são anóxicos, como por exemplo, aquíferos, sedimentos aquáticos e solos submersos de manguezais. Em tais condições, a biodegradação é realizada por micro-organismos anaeróbios estritos ou facultativos, utilizando aceptores de elétrons como o nitrato (desnitrificantes), sulfato redutores, redutores de $\mathrm{Fe}^{3+}, \mathrm{CO}_{2}$ (organismos metanogênicos), ou outros aceptores (Mn e Cr) (CHAKRABORTY et al., 2004; FOGHT, 2008; WIDDEL \& RABUS, 2001).

Condições metanogênicas e de redução de sulfato fornecem pouca energia às bactérias, entretanto, são fundamentais no metabolismo de linhagens fermentativas, pois estas, em geral, não fazem a biodegradação completa dos HPAs, tornando-se energeticamente favoráveis apenas quando micro-organismos metanogênicos ou bactérias redutoras de sulfato estão presentes no substrato, a fim de usar os produtos gerados durante a fermentação. Diferentemente, bactérias fotossintéticas obtêm energia da luz e degradam os compostos aromáticos anaerobicamente para formar metabólitos intermediários, como acetil-CoA, que são posteriormente utilizados em reações biossintéticas (DÍAZ, 2004).

O catabolismo anaeróbio de compostos aromáticos pode ser dividido em três fases: (1) os caminhos periféricos convergem para uma via central, formando um intermediário aromático, normalmente benzoil-CoA (CHAKRABORTY \& COATES, 2004; DÍAZ, 2004; FOGHT, 2008; HEIDER \& FUCHS, 1997); (2) Ocorre a abertura do anel aromático, convertendo o composto em 3-hidroxipimelil-CoA, que sofre a ação de uma desidrogenase sendo formado predominantemente glutaril-CoA ou, alternativamente, acetil-CoA (HEIDER \& FUCHS, 1997); (3) A enzima glutaril-CoA desidrogenase produz crotonil-CoA, e libera $\mathrm{CO}_{2}$. Segue-se então a transformação de crotonil-CoA em Acetil-CoA, que é oxidado, normalmente, via ciclo do ácido cítrico (HEIDER \& FUCHS, 1997).

Como se pode notar, a biodegradação assimilativa de HPAs serve como fonte de carbono e energia para os micro-organismos e é iniciada pela ação de diferentes enzimas oxigenases, as quais hidroxilam esses compostos. As enzimas monoxigenases participam, principalmente, das vias de degradação dos hidrocarbonetos alifáticos ou $n$-alcanos e as dioxigenases estão envolvidas na degradação de compostos aromáticos (ANDREONI \& GIANFREDA, 2007). Considerando-se a grande diversidade estrutural de hidrocarbonetos na 
natureza, é passível de se esperar que a diversidade destas enzimas e o número de rotas catabólicas sejam também significativos, apresentando grande potencial de aplicação biotecnológica, especialmente porque estas oxigenases participam da ciclagem do carbono na terra, além da remoção de compostos tóxicos em áreas impactadas (WATANABE et al., 2002; YATES et al., 2000).

\subsection{Enzimas ARHDs (Dioxigenases que Hidroxilam Anéis Aromáticos)}

Durante o processo de evolução a formação dos vários biopolímeros foi lenta e gradual, permitindo uma evolução paralela de vias catabólicas microbianas apropriadas para cada novo substrato que ia sendo disponibilizado, sendo esta uma das explicações para a grande versatilidade enzimática dos micro-organismos (SCULLION, 2006). As oxigenases são enzimas-chave no processo inicial de degradação de HPAs e elas existem sob formas variáveis na natureza, diferindo em sua estrutura, mecanismos e requerimento de co-fatores (ANDREONI \& GIANFREDA, 2007). Tais características tornam estas enzimas atrativas para a produção de compostos químicos de importância médica e industrial, além de fornecerem importantes informações para o desenvolvimento de metodologias de biorremediação (GIBSON et al., 2000).

As enzimas da família das ARHDs (Dioxigenases que Hidroxilam Anéis Aromáticos Aromatic Ring Hydroxylating Dioxygenases) são formadas por sistemas multi-competentes que iniciam a degradação de um composto pela incorporação de dois átomos de oxigênio molecular ao núcleo aromático do substrato e assim realizam a clivagem do anel benzênico destes compostos, requerendo os cofatores NADH e NADPH durante o processo (MISHRA et al., 2001; ZIELINSKI et al., 2002). Os subprodutos dessas reações são $\mathrm{CO}_{2}$ e água e os produtos finais da degradação são o succinato, acetil-CoA, ácido pirúvico, ácido acético e aldeídos, todos eles utilizados pelos micro-organismos na síntese de constituintes celulares e energia (BUTLER et al., 1996; GIBSON \& PERALES, 2000; PENG et al., 2010).

As ARHDs são compostas por subunidades proteicas transportadoras de elétrons, sendo elas uma flavoproteína redutase, uma ferrodoxina e uma oxigenase catalítica com duas subunidades de proteína ferro-enxofre (Fe-S): a subunidade alfa $(\alpha)$ e a subunidade beta $(\beta)$. A subunidade alfa é a porção que determina a especificidade da enzima pelo substrato e dividese em dois domínios: um centro catalítico Rieske - [2Fe-2S] e um sítio mononuclear de ferro, conforme mostrado na Figura 6 (KWEON et al., 2008; LOZADA et al., 2008; WITZIG et al., 2006). 
No sistema apresentado na Figura 6 é possível observar que (1) a redutase oxida $\mathrm{NAD}(\mathrm{P}) \mathrm{H}$ a $\mathrm{NAD}(\mathrm{P})^{+}$, capturando dois elétrons. (2) Esses elétrons são armazenados em uma flavina e são enviados, um por vez, para a (3) ferrodoxina. A ferrodoxina (4) lança o elétron recebido da redutase para o centro catalítico Rieske da oxigenase. Esse passo ocorre duas vezes para (5) cada molécula formada no sítio mononuclear de ferro. O resultado final é a dihidroxilação do anel benzênico do substrato. As fases seguintes envolvem a quebra do anel, com reações que levam à geração de compostos intermediários do ciclo do ácido tricarboxílico (FERRARO et al., 2005).

Figura 6. Sistema de três componentes das dioxigenases.

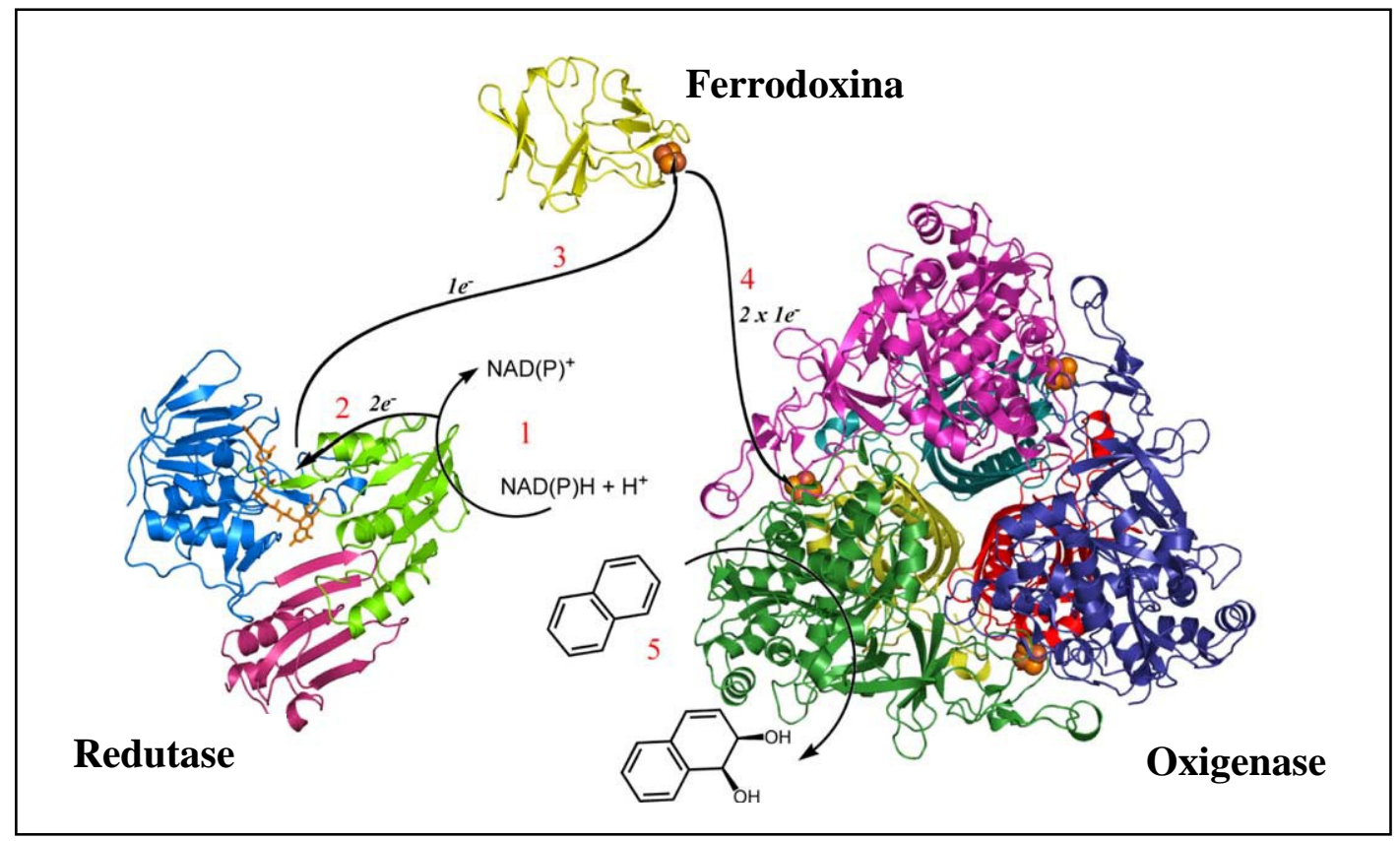

Fonte: Adaptado de Ferraro et al. (2005).

As enzimas ARHDs apresentam seqüências bastante diversas, devido provavelmente à dispersão destes genes via transposons e plasmídeos. Essas enzimas são codificadas pelos genes $\alpha$-ARHDs que, apesar de possuírem um ancestral comum, recebem uma denominação específica de acordo com o substrato degradado, como por exemplo, os genes bphA (bifenilo), bnzA (benzeno), ndoB (naftaleno), todC1 (tolueno), edoA (etilbenzeno), ebdA (alquilbenzeno), dentre outros (GIBSON \& PERALES, 2000; ZIELINSKI et al., 2002). Esses genes catabólicos recebem grande atenção como indicadores da presença de microorganismos com capacidade metabólica para degradação de HPAs em áreas impactadas (MARGESIN et al., 2003; PENG et al., 2010; WHYTE et al., 2002). 
Historicamente vários sistemas de classificação das ARHDs já foram propostos. Inicialmente a classificação dessas enzimas era feita em III classes, baseando-se no número de componentes da cadeia de transporte de elétrons e na natureza do centro catalítico (BATIE et al., 1991). Com o número crescente de dioxigenases sendo identificadas e caracterizadas, este sistema se tornou insatisfatório e uma segunda classificação foi proposta baseada no alinhamento das seqüências de aminoácidos da subunidade alfa, identificando IV famílias proteicas, referindo-se aos substratos naftaleno-I, tolueno/benzeno-II, bifenilo-III e benzoato/toluato-IV (WERLEN et al., 1996).

Novas classificações, acrescentando ou alterando algumas famílias, têm sido apresentadas, mas todas se baseiam na homologia das seqüências de aminoácidos da subunidade alfa e levam em consideração a especificidade da enzima pelo substrato e o tipo da cadeia de transporte de elétrons (GIBSON \& PERALES, 2000; KWEON et al., 2008; NAM et al., 2001; PARALES \& RESNICK, 2006). Na Figura 7 temos uma representação dessa classificação.

Neste sistema de classificação o Grupo I - Ftalato Dioxigenase representa o grupo das dioxigenases mais diverso, que catalizam a oxidação de uma variedade de compostos aromáticos estruturalmente não-relacionados, incluindo os substratos ftalato, p-tolueno, sulfonato, fenoxi-benzoato, carbazol e 2-oxo-1,2-dihidroquinolina. Duas ftalato dioxigenases de bactérias Gram-positivas foram identificadas recentemente, mas não agrupam com a família Ftalato e estão descritas na Figura 7 como Gram+HPA/Ftalato.

O Grupo II - Benzoato Dioxigenase consiste em enzimas que oxidam vários ácidos aromáticos e compostos aminoaromáticos. Os substratos catabolizados por essas enzimas incluem: benzoato, toluato, antranilato, 2-clorobenzoato, triclorofenoxiacetato e isopropilbenzoato. O Grupo III - Naftaleno Dioxigenase compreende as enzimas de degradação do naftaleno, fenantreno e nitroareno. Já o Grupo IV - Tolueno/Bifenilo dioxigenase é um grupo bastante coeso e inclui enzimas envolvidas na degradação de benzeno, tolueno, isopropilbenzeno, clorobenzenos e bifenilos. Uma nova família tem sido descrita e está sendo designada como Família Salicilato, que consiste em enzimas que catalizam a oxidação de salicilato e alguns outros substratos. Vale ressaltar que várias enzimas ARHDs não agrupam em nenhuma das famílias já descritas, como é o caso da 3fenilpropionato e da dibenzofurano dioxigenases (PARALES \& RESNICK, 2006).

Vários genes que codificam as enzimas associadas às vias de degradação de bifenilo (FURUKAWA \& FUJIHARA, 2008; LEE et al., 2011; UHLIK et al., 2009), tolueno (BOMBACH et al., 2009; LUO et al., 2009), benzeno (FAHY et al., 2005; HERRMANN et 
al., 2010), naftaleno (FILONOV et al., 2010; FLOCCO et al., 2009), xileno (BLUM et al., 2009), dentre outros compostos, foram clonados e descritos em diversos estudos ambientais, especialmente visando a construção de micro-organismos geneticamente modificados capazes de degradar esses compostos de forma mais eficiente (PIEPER et al., 2000; SUENAGA et al., 2001; SUENAGA et al., 2002).

Figura 7. Árvore filogenética das seqüências da subunidade alfa das enzimas ARHDs representando as famílias de dioxigenases.

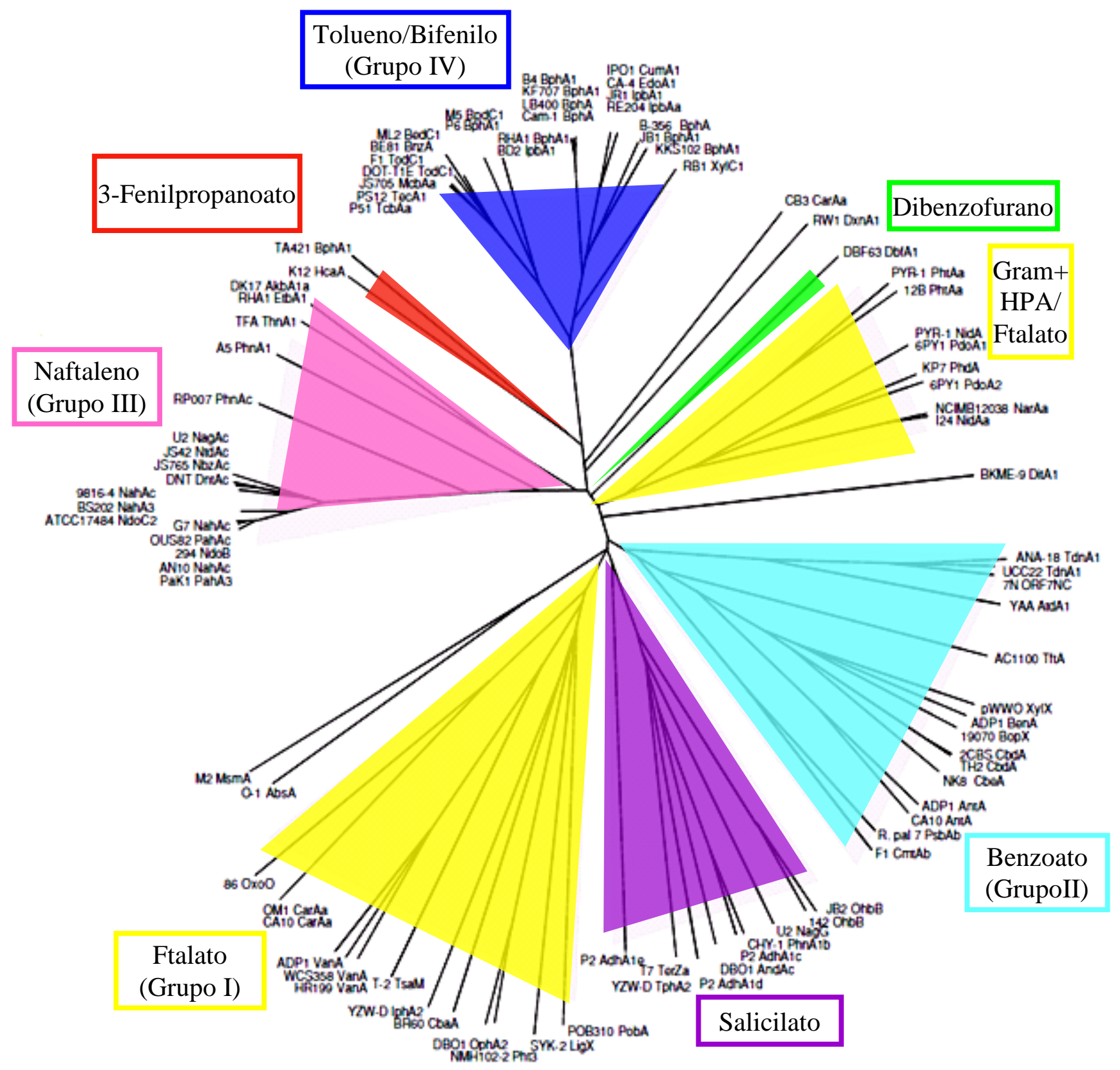

Fonte: Adaptado de Parales et al. (2006) 
Vale ressaltar que nos últimos anos, a detecção de genes que codificam dioxigenases, que era feita exclusivamente com primers específicos para cada gene, passou a ser realizada também com primers degenerados, devido à diversidade genética encontrada nas famílias das ARHDs. Esses primers foram desenhados com base na mesma região dos genes, que é a subunidade $\alpha$ do componente terminal da dioxigenase (BELICANTA, 2004; KUHN, 2007).

O desenho dos iniciadores para amplificação dos genes $\alpha$-ARHDs utilizado em nosso trabalho foi realizado por Belicanta (2004) a partir do alinhamento das seqüências similares a BphA1 de Pseudomonas pseudoalcaligenes KF707. No total, foram selecionadas 26 seqüências similares aos genes bphA (bifenil dioxigenase), bnzA (benzeno 1,2-dioxigenase), benA (benzoato 1,2-dioxigenase), ndoB (naftaleno 1,2-dioxigenase), cbaA (3-clorobenzoato 3,4dioxigenase), xylX (toluato 1,2-dioxigenase), todC1 (tolueno 2,3-dioxigenase), cumA1 (cumeno dioxigenase), ipbA1 (isopropilbenzeno 2,3-dioxigenase), edoA (etilbenzeno dioxigenase), ebdA (alquilbenzeno dioxigenase), entre outros genes que codificam a subunidade alfa das ARHDs.

Uma grande vantagem do uso dos primers degenerados é que os resultados obtidos a partir das bibliotecas de clones para detecção dos genes ARHD possibilitam também o emprego dos estimadores de diversidade (CHAO, ACE, Shannon-Weiner, rarefação e cobertura) aplicados à ecologia molecular de micro-organismos. No entanto estes índices foram desenvolvidos para o estudo da riqueza e equitabilidade de espécies, baseados no gene $16 \mathrm{~S}$ rRNA. O valor do corte (cutoff) necessário para definir os níveis de distância entre as sequências foi estabelecido para os níveis taxonômicos ou OTU (Operational Taxonomic Unit Unidade Taxonômica Operacional) ou filotipos (SCHLOSS et al., 2005) e não para os genes funcionais. Desta forma foi necessária a discussão e estabelecimento de novos critérios para a análise de sequência de proteínas associadas aos genes funcionais. Atualmente o termo OPF (Operational Protein Family - Família Proteica Operacional) foi determinado em substituição ao termo OTU (SCHLOSS et al., 2008).

\subsection{Vias de Degradação do Bifenilo}

São tradicionalmente conhecidas duas vias metabólicas para degradação de bifenilos policlorados em bactérias: a via aeróbia (degradação oxidativa) e a anaeróbia (descloração redutiva), que são utilizadas dependendo do número de átomos de cloro do composto, do tipo de micro-organismo envolvido e da disponibilidade de oxigênio no ambiente (AKEN et al., 2009; BORJA et al., 2005). 
A via anaeróbia de descloração dos bifenilos policlorados envolve a remoção de até dez moléculas de cloro, composto que serve como aceptor de elétrons, e sua substituição por hidrogênio. Apesar de o processo não resultar na degradação total dos bifenilos policlorados, esta descloração redutiva de moléculas de alto peso molecular reduz sua toxicidade e aumenta sua degradabilidade pelos micro-organismos aeróbios (BORJA et al., 2005; WIEGEL et al., 2000). A Figura 8 mostra algumas das possíveis vias (meta, para ou orto) para a descloração do 2,3,4,6-clorobifenilo (2346-CB) até 4-clorobifenilo (4B) ou 2-clorobifenilo (2B). Várias bactérias aneróbias têm sido isoladas pela sua capacidade de descloração de PCBs, dentre elas: Desulfomonile tiedjei, Desulfitobacterium, Dehalobacter restrictus, Dehaospirillum multivorans, Desulforomonas chloroethenica, Dehalococccoides ethenogenes e Enterobacter agglomerans (BORJA et al., 2005).

Figura 8. Vias anaeróbias para a descloração do 2,3,4,6-clorobifenilo.

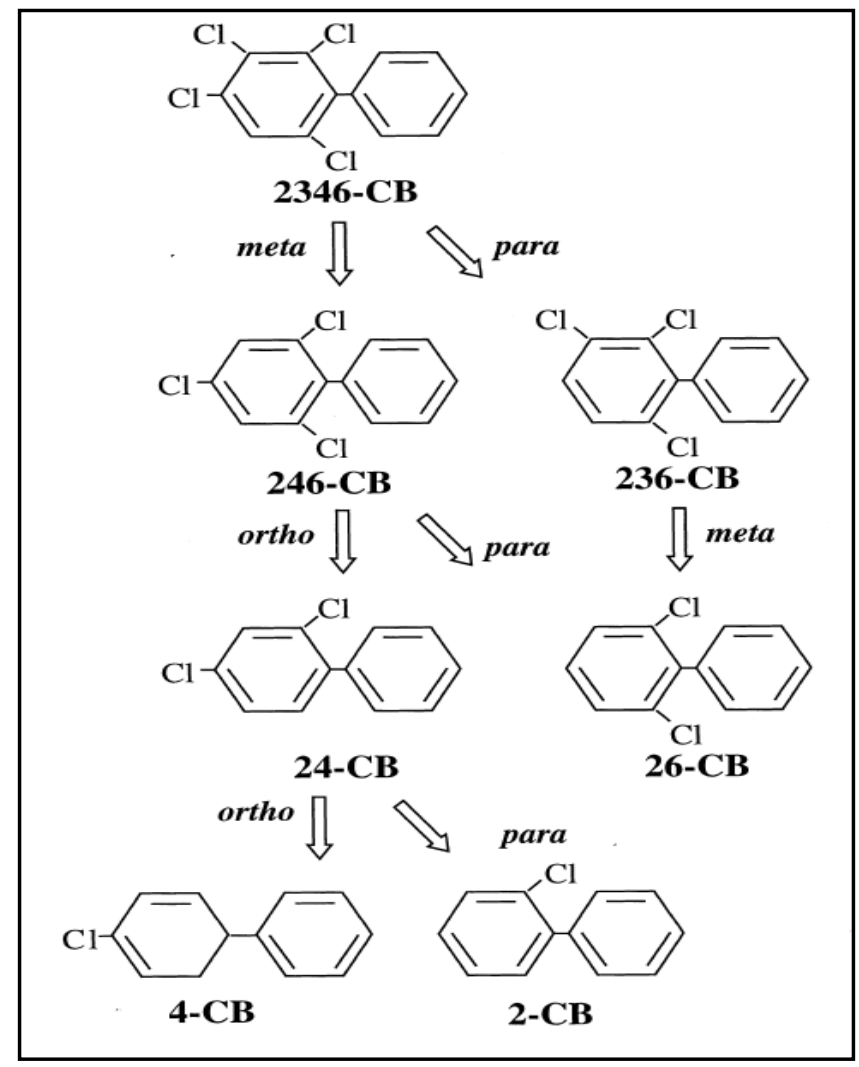

Fonte: Adaptado de Wiegel et al. (2000).

A via metabólica de degradação dos bifenilos policlorados por bactérias aeróbias é mais rápida que a anaeróbia e envolve a oxidação total dos PCBs, com no máximo 5 átomos de cloro, através da participação de várias enzimas e uma série de intermediários, podendo ser 
realizada por uma única ou mais espécies bacterianas agindo em sinergia. O processo inicia pela adição de oxigênio molecular na posição 2,3 da molécula de bifenilo por uma dioxigenase, seguida da desidrogenação, originando catecol e clivagem do anel, resultando no ácido benzóico e acetil-coA e como produtos finais da total degradação tem-se $\mathrm{CO}_{2}$, cloro e água (FURUKAWA \& FUJIHARA, 2008; FURUKAWA et al., 1986).

Em 1986 Furukawa et al. (FURUKAWA \& MIYAZAKI, 1986) clonaram pela primeira vez o gene bph que codifica as enzimas envolvidas na via de degradação do bifenilo, a partir do micro-organismo Pseudomonas pseudoalcaligenes KF707. Desde então, vários artigos têm sido publicados sobre a organização dos genes associados à degradação microbiana de bifenilos, os micro-organismos envolvidos e as enzimas associadas (KIMBARA, 2005; LEE et al., 2011; PIEPER, 2005; UHLIK et al., 2009). Enzimas como a bifenilo 2,3-dioxigenase têm sido extensivamente caracterizadas e suas relações de estrutura e sequência têm sido exaustivamente caracterizadas nos mais diversos micro-organismos (PIEPER, 2005).

O gene bph de Pseudomonas pseudoalcaligenes KF707 está organizado em um único operon denominado bphABCXD, como pode ser obervado na Figura 9. Neste microorganismo, que é capaz de degradar aerobicamente mono até triclorobifenilo, os genes que codificam as enzimas responsáveis pela degradação de PCBs estão localizados em um fragmento de 7,9 kb (FURUKAWA \& FUJIHARA, 2008).

Sobre este operon sabe-se que o gene bphA codifica o complexo enzimático da bifenilo dioxigenase $(\mathrm{BphA} 1$ = subunidade maior; $\mathrm{BphA2}=$ subunidade menor, $\mathrm{BphA}=$ ferrodoxina e $\mathrm{BphA} 4=$ redutase $)$, o gene $b p h \mathrm{~B}$ codifica a enzima desidrogenase $(\mathrm{BphB}=$ dihidrodiol desidrogenase), o bphC codifica a 2,3-dihidroxi-bifenilo dioxigenase (BphC), o bphX codifica quatro diferentes enzimas $(\mathrm{BphX0}=$ transferase, $\mathrm{BphX} 1=$ hidratase, $\mathrm{BphX} 2=$ desidrogenase, BphX3 = aldolase) e por último o gene $b p h \mathrm{D}$ codifica uma hidrolase denominada BphD. A proteína BphR1 é um regulador transcricional envolvido na expressão do bphR1 (regulador) e $b p h X 0 X 1 X 2 X 3 D$. A função do orf3 permanece incerta. (FURUKAWA \& FUJIHARA, 2008).

Na Figura 9 tem-se que a bifenilo dioxigenase (BphA), pela adição de $\mathrm{O}_{2}$, converte o bifenilo (I) a 2,3-di-hidroxi-4-fenilhexa-4,6-dieno (di-hidrodiol) (II). O composto II é convertido a 2,3-di-hidroxibifenilo (III) pela enzima di-hidrodiol desidrogenase (BphB). O composto III é clivado na posição 1,2 pela 2,3-di-hidroxibifenilo dioxigenase (BphC) para gerar o composto IV (ácido 2-hidroxi-6-oxo-6-fenil-hexa-2,4-dienóico) por meta clivagem. O composto IV é hidrolisado por meta-clivagem pela hidrolase (BphD) e produz ácido benzóico (V) e ácido 2-hydroxypenta-2,4- dienóico (VI). 
Figura 9. Via catabólica para a degradação aeróbia do bifenilo policlorado e organização do gene bph em Pseudomonas pseudoalcaligenes KF707.

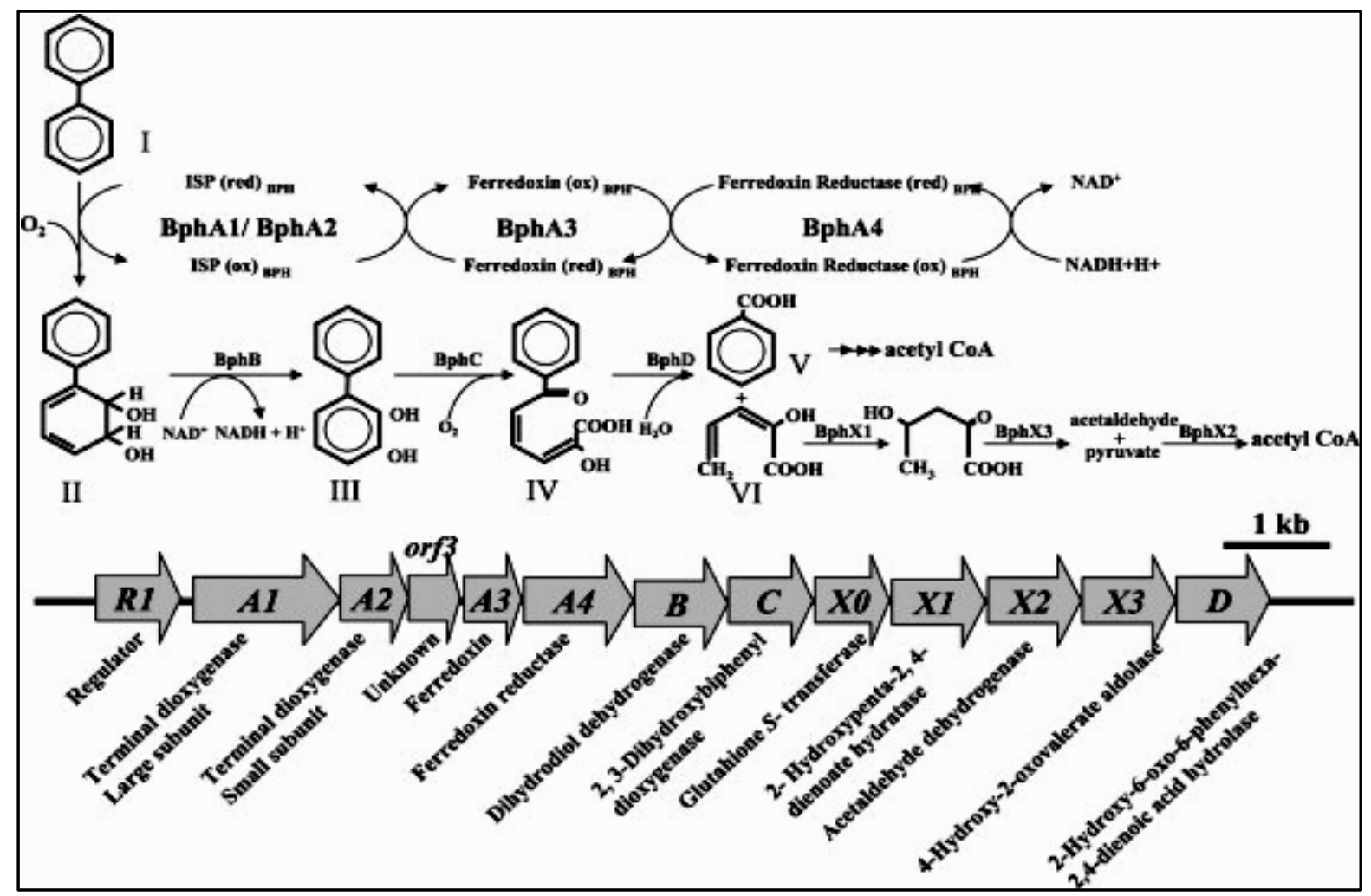

Fonte: Furukawa et al. (2008).

Baseando-se no número de trabalhos publicados de isolados que apresentam as vias de degradação de bifenilos, as bactérias mais citadas, tanto em solo como em sedimento, pertencem aos gêneros Achromobacter, Acinetobacter, Alcaligenes, Arthrobacter, Bacillus, Flavobacterium, Nocardia, Pseudomonas e Rhodococcus (FURUKAWA \& FUJIHARA, 2008). Mas micro-organismos dos gêneros Comamonas, Sphigobium, Acidovorax, Mycobacterium, Ralstonia e Micrococcus já foram mencionados em alguns trabalhos (DEANROSS et al., 2002; LEE et al., 2011; UHLIK et al., 2009). Nos últimos anos o uso de técnicas mais acuradas como o Stable Isotope Probing e pirosequenciamento tem permitido o conhecimento de micro-organismos envolvidos na biodegradação de compostos aromáticos não antes citados, como é o caso dos gêneros Pusillimonas e Variovorax (LEE et al., 2011).

\subsection{Estudo de Comunidades Microbianas}

Práticas tradicionais de cultivo de micro-organismos, principalmente baseadas em enriquecimento de culturas em meio seletivo, têm sido muito utilizadas ao longo dos anos 
com o objetivo de identificar as populações bacterianas que são funcionalmente importantes nos processos de biodegradação de compostos orgânicos (CHADHAIN et al., 2006). O ensaio de enriquecimento a partir do solo consiste geralmente na inoculação de uma pequena quantidade do sistema em meio mineral contendo unicamente hidrocarbonetos aromáticos como fonte de carbono e energia. O microcosmo é então submetido a condições de incubação por períodos que podem variar de poucos dias a meses, até o novo subcultivo para diluição da mistura inicial, que irá culminar nas diluições seriadas para isolamento de colônias puras com identificação taxonômica e descrição de vias metabólicas de interesse comercial, além de aumentar o acesso a novas fontes de genes de interesse biotecnológico. A grande desvantagem do processo de cultivo é a complexidade das comunidades microbianas e o fato de que menos de $1 \%$ dos micro-organismos presentes nos mais diversos ambientes são cultiváveis em meios artificiais (ENTCHEVA et al., 2001).

Atualmente a Microbiologia Ambiental tem revolucionado pela aplicação de metodologias independentes e não limitadas pelo cultivo de micro-organismos, com destaque para aquelas que utilizam a Reação em Cadeia da Polimerase (PCR) para a investigação da diversidade microbiana, tipicamente pela análise da amplificação dos genes que codificam o RNA ribossomal 16S (BURR et al., 2006; JANSSEN, 2006; RODRIGUES et al., 2002) ou para a detecção de genes funcionais específicos em amostras ambientais (BAKERMANS et al., 2002; DA SILVA et al., 2007).

A aplicação de técnicas de biologia molecular como DGGE (ZIEMBIŃSKA et al., 2009), T-RFLP (SIQUEIRA et al., 2010), PCR em tempo real (TAKETANI et al., 2009; ZHANG et al., 2008), Stable Isotope Probing - SIP (TOURNA et al., 2010), Microarranjo de DNA (WU et al., 2006) e Pirosequenciamento (IWAI et al., 2010; TEIXEIRA et al., 2010) tem oferecido novas formas de se detectar os micro-organismos no ambiente, permitindo estudar a distribuição e dispersão de diferentes genes em comunidades naturais ou alteradas, bem como a identificação de micro-organismos endêmicos e características genotípicas específicas presentes em micro-organismos de diferentes regiões geográficas (LEE et al., 2011; PEIXOTO et al., 2011; POWELL et al., 2006; SANTOS et al., 2011b; ZHANG et al., 2007).

É importante mencionar que o estudo da função gênica requer a habilidade para quantificar com precisão os padrões espaciais e temporais da expressão de um gene e, dado o recente avanço genômico, este requerimento tem se tornado cada vez mais essencial. Desta forma, análises da expressão gênica, realizadas por meio da técnica de PCR em tempo real 
têm sido cada vez mais numerosas, representando uma de suas principais aplicações (PEIRSON et al., 2003).

\subsection{A Técnica de PCR em Tempo Real}

A quantificação de genes funcionais no ambiente é um importante passo no entendimento de muitos processos ecológicos (GRUNTZIG et al., 2001; KLEIN, 2002). A PCR (Reação em Cadeia a Polimerase - Polimerase Chain Reaction) é uma técnica bastante sensível (VALASEK et al., 2005) que consiste em fazer cópias de um DNA (DNA-molde) utilizando os elementos básicos do processo de replicação natural desta molécula (FERRE, 1992; MULLIS, 1990) e a introdução da tecnologia da PCR quantitativa (qPCR) tem sido utilizada nos últimos anos para a quantificação de populações microbianas em amostras ambientais, incluindo sedimentos marinhos (STULTS et al., 2001), lodo ativado (DIONISI et al., 2003), solos (KOLD et al., 2003), sedimentos de manguezais (TAKETANI et al., 2009) e água (JOLY et al., 2006; YÁÑEZ et al., 2005).

A PCR quantitativa (qPCR) é também denominada PCR em Tempo-Real (Real-Time PCR) e representa hoje um grande avanço, pois associa a sensibilidade da PCR à precisão proporcionada pela quantificação dos produtos de PCR à medida que eles são gerados, o que significa que os dados são coletados durante todo o processo de PCR e não no final da reação (VALASEK \& REPA, 2005). A técnica baseia-se na detecção e quantificação da fluorescência gerada por sondas (TaqMan) ou corantes fluorescentes (SYBR Green ). O sinal aumenta numa proporção direta à quantidade de produto do PCR na reação (HRISTOVA et al., 2001). Obtendo a quantidade de emissão fluorescente em cada ciclo, é possível monitorar a reação de PCR durante a fase exponencial onde o primeiro aumento significativo na quantidade de produto, correlaciona-se com a quantidade inicial do DNA-alvo.

Os Cts (cycle threshold) são definidos como o número de ciclos requeridos para que o sinal fluorescente exceda o nível de ruído (background) e é inversamente proporcional a quantidade de DNA-alvo presente na amostra. Quanto maior o número de cópias iniciais do DNA, mais rápido é observado um aumento significativo na fluorescência (WALKER, 2002; ZHANG et al., 2006).

Análises da expressão gênica, realizadas por meio da técnica de qPCR, têm sido cada vez mais numerosas, representando uma de suas principais aplicações (PEIRSON et al., 2003). A técnica possibilita, além de uma quantificação monitorada, um diagnóstico rápido e 
preciso da abundância de um gene de interesse a partir de amostras ambientais, predizendo o potencial de uma área para processos de biorremediação (POWELL et al., 2006; VALASEK \& REPA, 2005).

Diversos autores vêm utilizando-se da técnica de qPCR para quantificação dos mais variados genes funcionais. Mesarch et al. (2000) descreveram a técnica de qPCR para monitorar o gene catecol-2,3-dioxigenase com o objetivo de quantificar as bactérias com habilidades catabólicas para degradar hidrocarbonetos aromáticos e bifenilo em uma área impactada e em processo de biorremediação.

Para uma avaliação do papel e significado ecológico do gene alkB (que codifica para a alcano-monoxigenase) na degradação do $n$-heptano, Heiss-Blanquet et al. (2005), utilizaram a qPCR, para quantificar e investigar a ocorrência e distribuição desse gene em diferentes ambientes. Os autores concluíram que a predominância do genótipo alkB depende do ecossistema e das condições ambientais, mas a exposição ao alcano geralmente resulta em um aumento da presença do gene.

Powell et al. (2006) utilizaram com sucesso a qPCR para quantificar a enzima alcanomonoxigenase na comunidade microbiana durante uma tentativa de biorremediação de um solo da Antártica contaminado com hidrocarbonetos. Os resultados obtidos indicaram que a proporção de micro-organismos contendo o gene alkB foi positivamente correlacionada à concentração de $n$-alcanos no solo e que após a redução dos $n$-alcanos a proporção de microorganismos degradando o composto também diminuiu, mas a proporção total de microorganismos degradando hidrocarbonetos aumentou, indicando uma mudança na estrutura da comunidade durante o processo.

Os estudos acima mencionados corroboram com o conhecimento de que no ambiente uma grande variedade de bactérias participa da degradação de contaminantes orgânicos, portanto uma melhor interpretação da dinâmica da comunidade microbiana que ocorre durante o processo de descontaminação é importante para o desenvolvimento de um processo de remediação mais eficiente (NYYSSÖNEN et al., 2006), especialmente pelo fato de diversas bactérias estarem associadas com diferentes fases da degradação de poluentes (KATSIVELA et al., 2004).

Identificar, caracterizar e quantificar os micro-organismos presentes em amostras de solo são grandes desafios, devido à sua vasta diversidade. Por esse motivo, estudos recentes também têm utilizado tecnologias de análise em larga escala para avaliar a diversidade taxonômica e funcional das comunidades microbianas (WU et al., 2006). Técnicas como o pirosequenciamento (454 Life Sciences, Roche, EUA), possibilitam a geração de centenas de 
milhares de seqüências distintas do gene-alvo, uma vez que aumentam a amostragem de seqüências de DNA em várias ordens de grandeza, permitindo a detecção mais precisa dos membros menos abundantes e raros das comunidades microbianas. Esta técnica tem sido utilizada e com a finalidade de explorar a extensa diversidade microbiana nos mais variados ambientes (HALL, 2007)

\subsection{Sequenciamento e Pirosequenciamento}

As técnicas de sequenciamento de DNA são usadas para a determinação da ordem precisa de nucleotídeos em uma amostra de DNA. Esta técnica é provavelmente a mais importante disponível para o biologista molecular. O sequenciamento do DNA é utilizado em diferentes aplicações, como na área forense, diagnóstico, estudos evolutivos e para a determinação do genoma total dos mais diversos organismos. As tecnologias de sequenciamento de DNA disponíveis atualmente incluem o método de Sanger, que é baseado na detecção da molécula de DNA fita simples sintetizada com o uso de di-deoxinucleotídeos (SANGER et al., 1977), o método de Maxam-Gilbert, que utiliza a degradação química de DNA de fita simples (MAXAM et al., 1977), sequenciamento por hibridização, que é baseado na hibridização de uma molécula marcada de DNA fita simples (de sequência desconhecida) a um conjunto de sequências específicas imobilizadas em um suporte sólido (DRAMANAC et al., 1989) e a tecnologia do Pirosequenciamento, uma tecnologia mais recente baseada em uma abordagem luminescente (RONAGHI et al., 1998). Em nosso trabalho iremos abordar o sequenciamento pelo método de Sanger e o Pirosequenciamento.

O método mais tradicional de sequenciamento foi proposto por Frederik Sanger na década de 70 (SANGER et al., 1977) e permite aos cientistas ainda hoje sequenciar eficientemente uma molécula de DNA. Neste método, que vem passando por melhorias desde sua criação, o DNA de fita simples serve como um molde para a síntese in vitro de outra fita de DNA usando um oligonucleotídeo iniciador (primer) com uma sequência complementar ao DNA-molde (SANGER et al., 1978). A enzima DNA polimerase faz a extensão da fita de DNA complementar e nessa reação de sequenciamento dNTPs naturais são misturados a dideoxinucleotídeos (ddNTPs) marcados com corantes fluorescentes e que não possuem a região 3’OH sendo que, desta forma, terminam a elongação da cadeia da DNA polimerase. As reações de elongação do DNA ocorrem com dNTPs/ddATP, dNTPs/ddCTP, dNTPs/ddGTP e dNTPs/ddTTP, respectivamente. Como os dNTPs estão em excesso na reação em comparação aos ddNTPs, diferentes comprimentos de fragmentos de DNA podem ser obtidos e a detecção 
destes fragmentos é realizada após a excitação por um feixe de laser e os fragmentos gerados são separados por capilaridade (HALL, 2007). A ordem em que os diferentes fragmentos passam pelo detector de fluorescência indica a sequência da cadeia de DNA complementar à cadeia usada como molde (KUMAR et al., 2007; MITCHELSON et al., 2007).

O sequenciamento de DNA se tornou uma das mais importantes ferramentas para análise de sistemas biológicos e nas últimas décadas, diferentes técnicas de sequenciamento em larga escala têm sido propostas, tornando possível o sequenciamento do genoma humano e de muitos outros organismos de forma rápida e a um baixo custo (EDWARDS et al., 2007; ELAHI et al., 2004; KUMAR \& FULLER, 2007; MARGULIES et al., 2005). Uma das tecnologias mais recentos é o sequenciamento massivo de DNA (Pirosequenciamento) desenvolvido pela 454 Life Science (Roche Applied Sciences, Bélgica), que constitui uma metodologia rápida, que permite a obtenção de centenas de milhares de sequências de DNA, com resultado em tempo real e altamente propício para o sequenciamento de segmentos curtos, além disso, dispensa a etapa exaustiva de construção de bibliotecas genômicas e clonagem do gene-alvo (HUSE et al., 2007; MARDIS, 2008; RONAGHI et al., 2002).

Ronaghi e colaboradores (1996) foram os primeiros a descrever a técnica, demonstrando que a molécula de pirofosfato (PPi) produzida durante a reação de polimerização do DNA poderia ser utilizada para detectar a incorporação de um nucleotídeo específico. O método foi denominado "sequenciamento por síntese”, uma vez que a sequência-alvo é determinada à medida que é sintetizada a fita complementar. Todo o processo envolve a participação quatro enzimas, responsáveis pela síntese da fita complementar através da incorporação de nucleotídeos, e da conversão do PPi em ATP e consequentemente em sinal luminoso, que é detectado pelo equipamento (RONAGHI, 2001).

Binladen et al. (2007) aperfeiçoaram a técnica de pirosequenciamento com o uso de primers marcados na PCR. De forma semelhante Parameswaran e colaboradores (PARAMESWARAN et al., 2007), propuseram a adição de uma sequência curta de nucleotídeos (tag ou barcode) ao primer utilizado na reação de PCR para a detecção do genealvo. Este código de barras permitiu o uso da técnica de pirosequenciamento para várias amostras diferentes em paralelo, pois as seqüências podem ser utilizadas posteriormente como referência na identificação e separação de diferentes amostras por ferramentas de bioinformática.

A Figura 10 mostra uma visão geral do pirosequenciamento. Inicialmente faz-se uma reação de PCR utilizando-se primers que possuem adaptadores e barcodes em suas extremidades. Esse produto de PCR é então submetido a purificação para remoção de dímeros 
de primers e de produtos inespecíficos. Para a realização do pirosequenciamento o fragmento de DNA (produto de PCR purificado), contendo os adaptadores em suas extremidades, é separado em fitas simples (A) e imobilizado em microesferas revestidas de primers (B) de modo que cada esfera transportará no máximo um fragmento de DNA (C). As micro-esferas são então compartimentalizadas em uma emulsão termoestável onde se realiza uma reação convencional de PCR, e ao final desta reação cada esfera estará revestida com milhões de cópias do fragmento de DNA inicial (D). As microesferas são recuperadas a partir da emulsão, as fitas de DNA desnaturadas e as microesferas, agora carregando milhões de cópias de DNA fita simples, são depositadas nos poços de uma placa de fibra-ótica (E). Grânulos ainda menores, que transportam as enzimas necessárias para o pirosequenciamento, são depositados em cada poço (F) (KELLY et al., 2007).

Figura 10. Visão geral do método de pirosequenciamento.
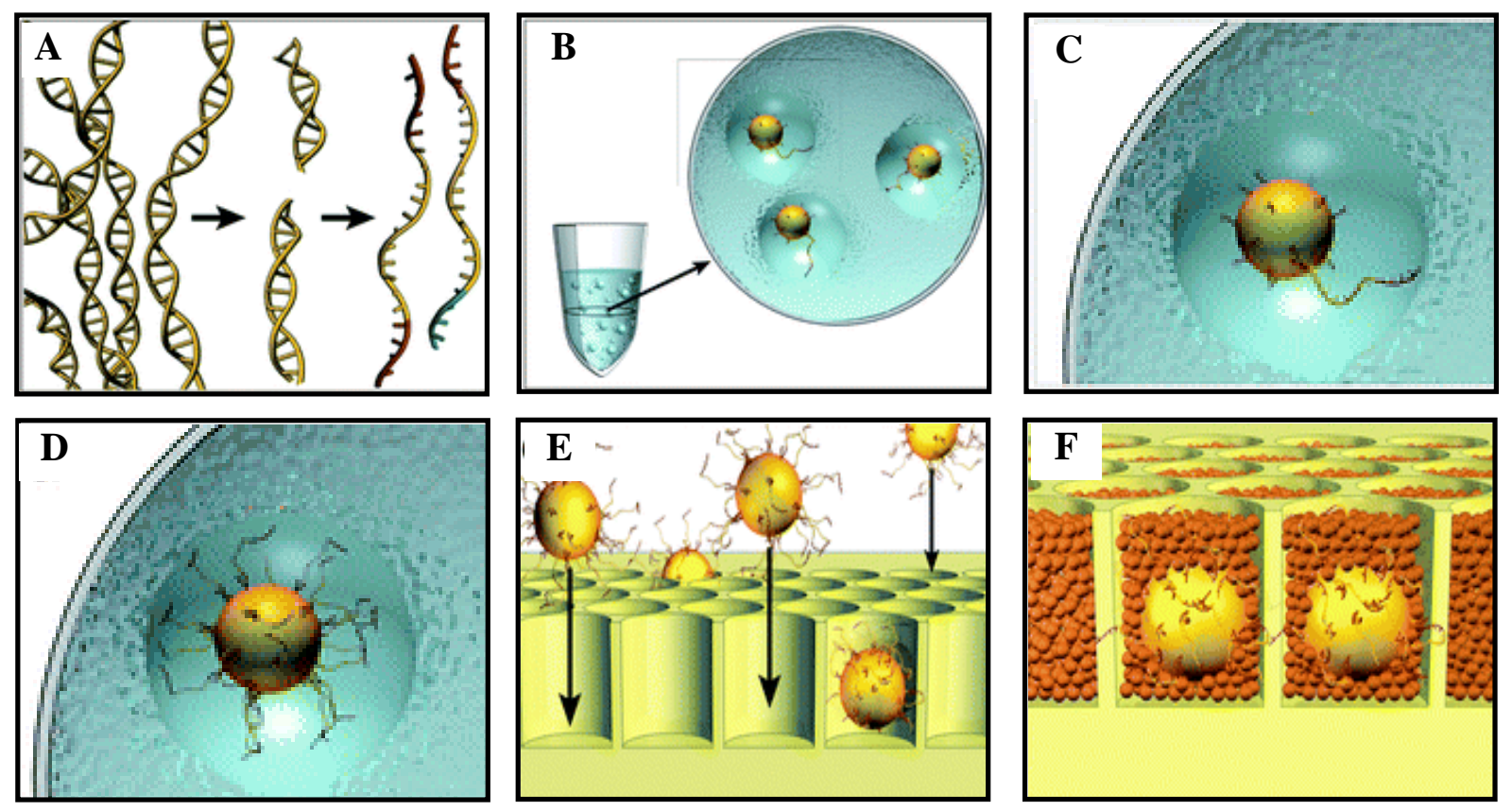

Fonte: Adaptado de Kelly et al. (2007)

As enzimas responsáveis pela reação de pirosequenciamento são: DNA polimerase, ATP sulfurilase, luciferase, pirase e os substratos APS (adenosina 5'fosfosulfato) e luciferina. Os quatro dNTPs são adicionados à reação sequencialmente e quando a DNA polimerase incorpora o nucleotídeo complementar ao DNA molde, o PPi é liberado em uma quantidade equimolar à incorporação nucleotídica. A ATP sulfurilase converte o PPi a ATP na presença da APS. O ATP que é produzido fornece energia para que a luciferase oxide a luciferina a oxiluciferina em uma reação que gera luz visível em quantidade proporcional à quantidade de 
ATP. A intensidade luminosa emitida pela reação é monitorada em tempo real, registrada por um detector de fótons e gravada como um pico em um pirograma. A conversão de PPi em luz é um processo estequiométrico, onde cada molécula de PPi gera uma quantidade de fótons proporcional ao número de nucleotídeos incorporados. O excesso de ATP e de nucleotídeos não incorporados é continuamente degradado pela enzima apirase. Quando a degradação está completa, outro dNTP é adicionado. Os dNTPs são adicionados um por vez e como o processo é contínuo, uma fita complementar de DNA é formada e a sequência de nucleotídeos é determinada a partir dos picos gerados no pirograma (MARDIS, 2008; MARSH, 2007; NOVAIS et al., 2011)

As reações e enzimas envolvidas no pirosequenciamento podem ser observadas a seguir e na Figura 11.

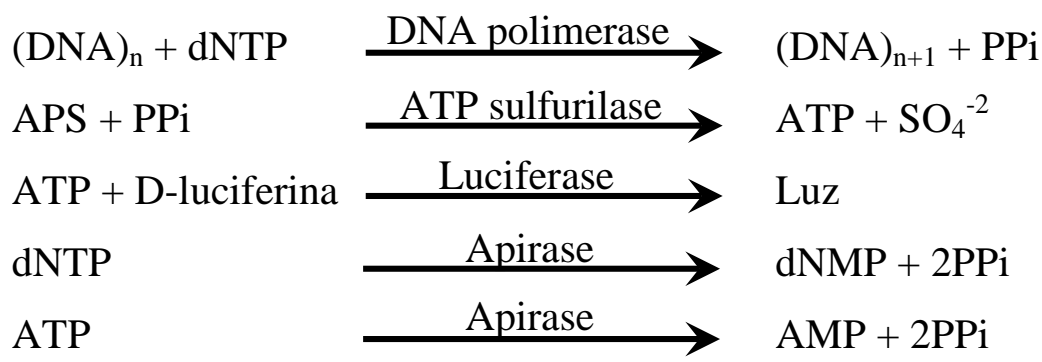

Dentre as quatro enzimas mencionadas, a DNA polimerase I é a mais popularmente conhecida. Esta enzima possui, além da atividade de polimerase, a atividade de exonuclease 3’- 5'e 5'- 3'. Durante o processo de polimerização os nucleotídeos são incorporados à região 3’ da fita que está sendo produzida. Esta enzima inicialmente se liga à região 3'-OH do primer hibridizado ao DNA-molde e então seleciona o nucleotídeo correto. Esta seletividade torna melhor a fidelidade da replicação (KORNBERG et al., 1992).

A ATP sulfurilase consiste de seis subunidades idênticas e tem um peso molecular de $315 \mathrm{kDa}$. Esta enzima tem sido detectada em muitos organismos, incluindo leveduras, fungos filamentosos, espinafre e ratos. A primeira enzima ATP sulfurilase clonada foi da levedura Saccharomyces cerevisiae, e esta é a única enzima comercialmente disponível (BRANDAN et al., 1988; RENOSTO et al., 1993; SEGEL et al., 1987).

A enzima luciferase catalisa a produção de luz em diferentes organismos e como essa emissão pode ser monitorada com grande sensibilidade, muitas aplicações baseadas nesta reação têm sido desenvolvidas. A luciferase do vaga-lume Photinus pyralis tem $61 \mathrm{kDa}$, produz luz no comprimento de onda 550-590nm com uma emissão máxima de 562nm a um 
pH 7,5 a 8,5 e foi a primeira a ser clonada e sequenciada (HOSSEINKHANI, 2011; VIVIANI, 2002).

A apirase catalisa a hidrólise das pontes de pirofosfato em tri e difosfatos, liberando ortofosfato. Esta enzima possui um peso molecular de $49 \mathrm{kDa}$ e tem sido identificada em diferentes organismos, sendo que aquela proveniente da batata (Solanum tuberosum ) é a mais extensivamente estudada (TRAVERSO-CORI et al., 1965).

Figura 11. Ilustração das etapas do pirosequenciamento

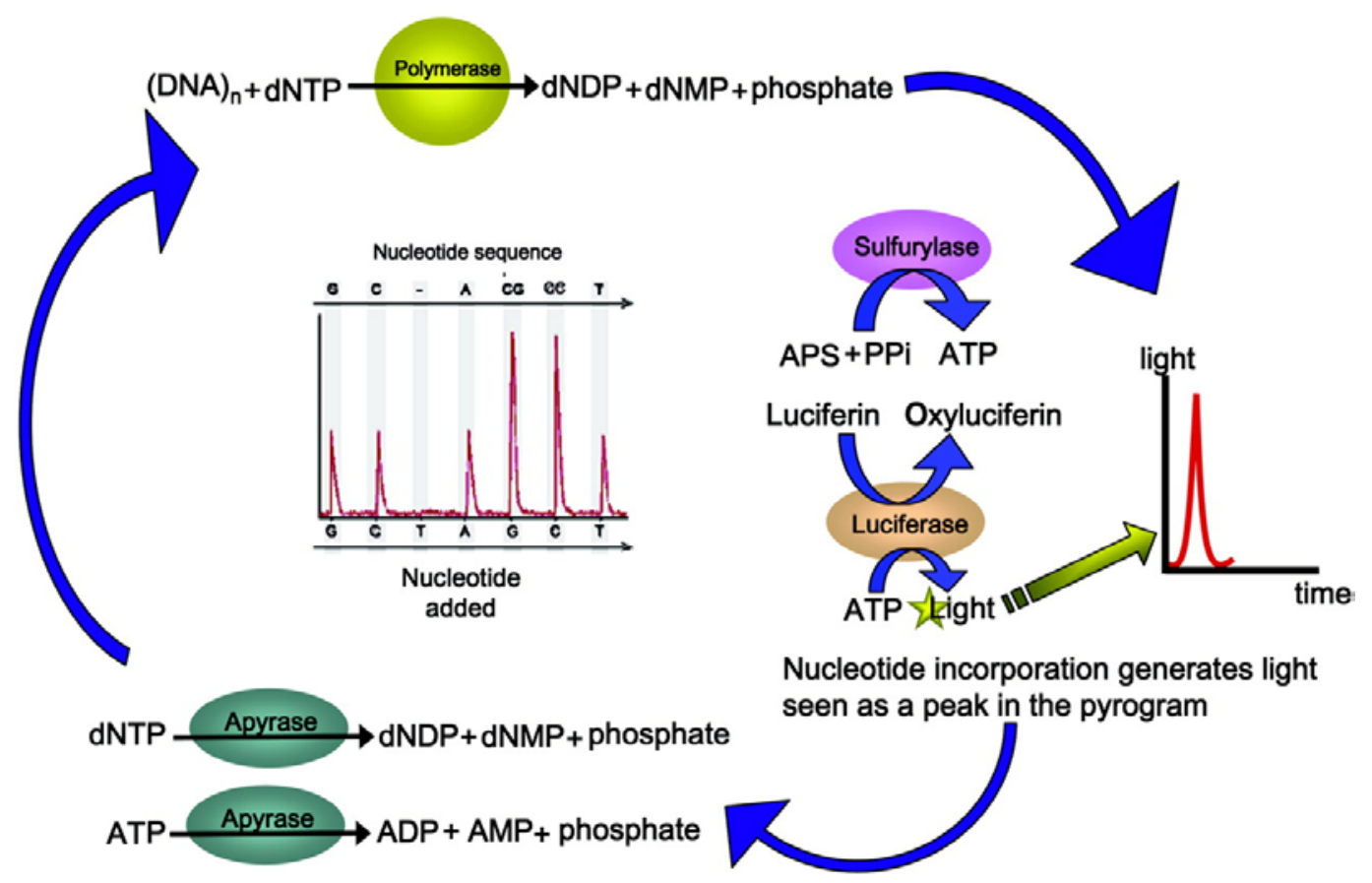

Fonte: Adaptado de Petrosino et al. (2009)

Várias abordagens estatísticas têm sido utilizadas para estimar e comparar a diversidade de procariotos, bem como as estruturas de suas comunidades em diferentes ambientes. Normalmente a diversidade e a estrutura de comunidades microbianas são analisadas em função da ocorrência de Unidades Taxonômicas Operacionais (OTUs - Operational Taxonomic Units), Famílias Proteicas Operacionais (OPF - Operational Protein Family) ou filotipos, já que o conceito de espécie, principalmente para os procariotos, é bastante controverso (HAUSDORF, 2011; KÄMPFER et al., 2012; OGUNSEITAN, 2007; ROSSELLÓ-MORA et al., 2001). Mas os critérios para definição das OTUs não são consensuais, principalmente quando se discute a distância evolutiva limite para que uma sequência represente uma OTU. Normalmente as sequências com similaridade > 97\% são consideradas da mesma espécie, > 95\% são consideradas do mesmo gênero, $>90 \%$ são 
consideradas da mesma família e $>80 \%$ do mesmo filo (KONSTANTINIDIS et al., 2006; MCINERNEY et al., 2008; ROSSELLÓ-MÓRA, 2012; SCHLEIFER, 2009; SCHLOSS \& HANDELSMAN, 2005). Estes valores de cutoff são os que mais se adequam à taxonomia bacteriana, mas não podem ser considerados rigorosamente válidos para uma classificação hierárquica precisa (ROSSELLÓ-MÓRA, 2012). Mais controverso ainda é a classificação das OPFs, para as quais ainda não existe consenso sobre os valores de cutoffs que as represente.

Uma das limitações das técnicas de clonagem e sequenciamento, e que dificultam uma inferência estatística mais precisa, é a baixa detecção de micro-organismos raros (baixa abundância), mas com o advento do pirosequenciamento este problema está sendo contornado e vários trabalhos em ecologia microbiana têm sido publicados utilizando esta metodologia para os mais diversos ambientes e amostras, incluindo solos (ROESCH et al., 2007), rizosfera de plantas da Antártica (TEIXEIRA et al., 2010) e sedimento de manguezais (ANDREOTE et al., 2012; ARFI et al., 2012; SANTOS et al., 2011b).

A técnica de pirosequenciamento também já foi utilizada para análise da diversidade do gene 16S rRNA utilizando amostras de sedimento de manguezais do Brasil. Santos et al. (2011b) utilizaram a técnica para análise da alteração da comunidade microbiana pelo uso de microcosmos simulando um derramamento de petróleo em amostras de sedimento de manguezal preservado da Restinga da Marambaia no Rio de Janeiro. A importância do referido trabalho se dá por conta da indicação de alguns gêneros microbianos como indicadores por apresentarem sensibilidade ou por serem estimulados pela presença do óleo.

Andreote e colaboradores (2012) também utilizaram a técnica de pirosequenciamento para uma profunda análise metagenômica da comunidade microbiana nos manguezais de Cananéia e Bertioga no estado de São Paulo. Este trabalho, além de contribuir para uma caracterização das comunidades microbianas de manguezais com diferentes históricos de contaminação, também apresenta aspectos referentes às vias metabólicas potenciais nestes ambientes.

A maior parte dos estudos utiliza o pirosequenciamento para análise da diversidade do gene 16S rRNA, mas recentemente a técnica também vem sendo usada para o estudo de genes que codificam dioxigenases aromáticas. O metagenoma gene-específico apresenta uma abordagem alternativa para a caracterização de comunidades microbianas complexas relacionadas a um processo específico e foi utilizada pela primeira vez por Iwai et al. (2010) revelando uma imensa diversidade do gene bph em uma área contaminada com este composto. Posteriormente Lee et al. (2011) também utilizaram o metagenoma gene-específico em associação com a técnica de Stable Isotope Probing para caracterização da população 
ativa na biodegradação do bifenilo em amostras de sedimento na Coréia. No Brasil a técnica também foi utilizada por Silva (2011) para caracterização da diversidade de genes associados à degradação de hidrocarbonetos (bifenilo) em amostras de solo de Terra Preta de Índio na Amazônia, revelando uma comunidade bastante diversa.

Vale ressaltar que as técnicas moleculares envolvendo sequenciamento em larga escala, como o pirosequenciamento, possibilitam a geração de um grande número de sequências-alvo, uma vez que aumentam a amostragem de sequências de DNA em várias ordens de grandeza, permitindo a detecção mais precisa de membros menos abundantes e raros nas comunidades microbianas, em um curto espaço de tempo (HALL, 2007). Mas apesar das inúmeras vantagens que o pirosequenciamento proporciona, é uma técnica que se baseia na análise de um único gene, e para trabalhos que buscam avaliar um grande número de genes o pirosequenciamento demandaria muito tempo e recursos. Portanto, no que se refere a estudos relacionados à detecção funcional em comunidades microbianas, uma tecnologia de crescente uso e constante amadurecimento é a de microarranjos de DNA, tradução do termo DNAMicroarray (EHRENREICH, 2006).

\subsection{Microarranjos de DNA - GeoChip}

A primeira menção aos microarranjos de DNA foi publicada por Schena et al. (1995), mas antes disso, a ideia de anexar sequências de DNA a suportes sólidos, como vidro ou filtro, já havia sido concebida por Edwin Southern na técnica de Southern Blot. O diferencial da organização de várias sequências com a possibilidade de uma análise de muitos genes simultaneamente impulsionou a estabilização dos microarranjos de DNA (BALDI et al., 2002).

A essência da tecnologia de microarranjos é a hibridização paralela de uma mistura de ácidos nucleicos desconhecidos (marcados com corante fluorescente), denominados “alvos” com centenas de sequências de ácidos nucleicos, de origem conhecida, denominadas “sondas”, que podem ser identificadas pela sua posição espacial em um suporte. A localização específica de uma sonda no suporte é denominada spot ou ponto. Enquanto as sondas estão imobilizadas no suporte sólido, os “alvos” são aplicados como uma solução sobre esse suporte após a marcação fluorescente (BROWN et al., 1999; EHRENREICH, 2006). Uma característica importante da técnica é seu poder quantitativo, sendo a intensidade de sinal de cada sonda proporcional à abundância do gene na amostra (TIQUIA et al., 2004). Um outro fator importante a se considerar é o limite de detecção da técnica, por isso utiliza-se uma alta 
concentração de DNA (1 a 5 ug), com elevada pureza, considerando-se que muitos genes podem estar presentes em baixíssima quantidade no ambiente. Além disso, a técnica é sistematicamente avaliada em termos de especificidade, sensibilidade e quantificação (ZHOU, 2003).

Com base no tipo de sonda, os microarranjos usados em estudos ambientais podem ser divididos em três classes principais: arranjos de genes funcionais (Functional Gene Arrays FGAs), arranjos de genomas da comunidade (Community Genome Arrays - CGAs) e arranjos de oligonucleotídeos filogenéticos (RHEE et al., 2004). Os primeiros estudos desenvolvidos com a metodologia de microarranjos e que impulsionaram seu refinamento concentravam-se na área médica, especialmente na área de diagnóstico de câncer (CHEUNG et al., 1999). Em microbiologia, os microarranjos de DNA foram primeiramente desenvolvidos e utilizados para perfis da expressão genética de culturas puras de organismos individuais (CHO et al., 2001; GENTRY et al., 2006). Já na área da ecologia microbiana, os microarranjos de DNA foram inicialmente utilizados por Guschin et al. (1997) devido à possibilidade de detectar, de forma bastante precisa, diferentes genes envolvidos em ciclos biogeoquímicos e biodegradação de compostos, (DUBEY et al., 2006). No caso da análise funcional de comunidades microbianas a equipe do Dr. Jizhong Zhou (2003) do Institute for Environmental Genomics vem desenvolvendo, nas últimas décadas, microarranjos de DNA denominados GeoChips (FGA), para serem utilizados na detecção de genes funcionais que codificam para enzimas-chave envolvidas em processos microbianos em amostras ambientais. Estes GeoChips vêm se tornando uma ferramenta poderosa para caracterização de comunidades microbianas em relação à diversidade funcional, composição, estrutura e atividade metabólica.

A tecnologia de microarranjos de DNA tem sido considerada uma ferramenta metagenômica específica, sensível, quantitativa e com alto rendimento para caracterizar e monitorar comunidades microbianas em resposta a estímulos. Pode ser utilizada para análise de comunidades de diferentes habitats, focando em diversos problemas relacionados às mudanças globais, uso e manejo do solo e também para monitorar processos de biorremediação (HE et al., 2008).

A seleção dos genes que irão compor a lâmina do GeoChip é uma etapa crucial na técnica de microarranjos e estes genes devem codificar enzimas ativas e estar diretamente envolvidos em processos metabólicos de interesse, além de atender a parâmetros rigorosos de identidade e especificidade (HE et al., 2007; HE et al., 2011). Os microarranjos de DNA são preparados de forma automatizada, onde um robô imprime, ordenadamente, em uma lâmina, 
milhares de fragmentos de DNA correspondente à sequência de gene, onde cada ponto corresponde a uma sonda (sequência de DNA) única (BALDI \& HATFIELD, 2002). A Figura 12 apresenta um esquema ilustrativo das principais etapas envolvidas na técnica de microarranjos de DNA funcional (GeoChip).

Figura 12. Esquema geral envolvendo as principais etapas da técnica de microarranjos de DNA (GeoChip).
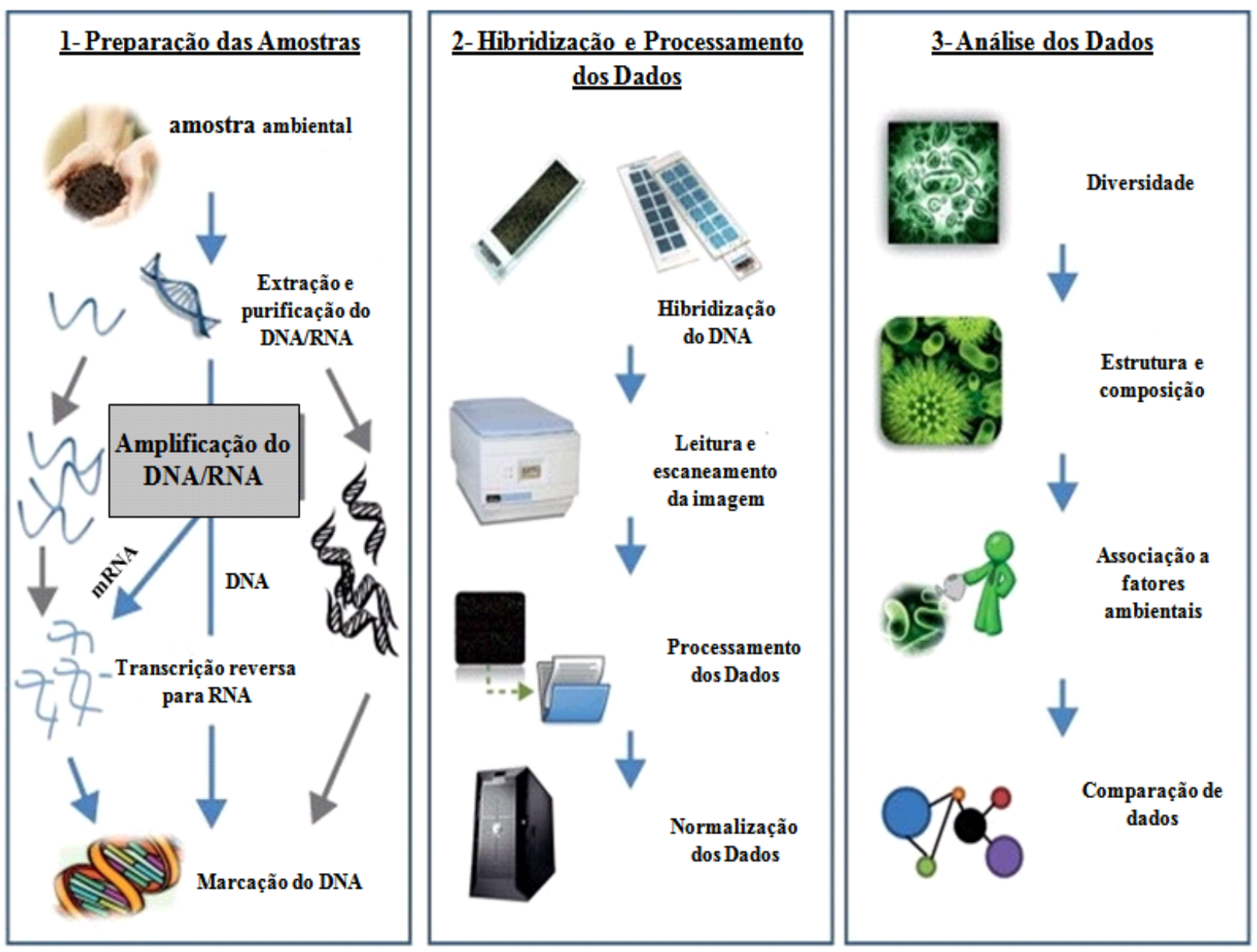

Fonte: Adaptado de He et al. (2012b)

A realização da técnica pode ser didaticamente dividida em algumas etapas: 1) o material genético a ser estudado é marcado com corante fluorescente; 2) o microarranjo e a amostra marcada são hibridizados, sob condições específicas; 3) os suportes sólidos são lavados, de forma especial para que apenas as sequências marcadas que hibridizaram permaneçam no chip, lembrando que em cada lâmina podem ser analisadas tantas amostras quantas tenham sido marcadas com diferentes corantes fluorescentes; 4) os microarranjos são excitados por laser e escaneados para a geração de uma imagem e 5) finalmente as análises 
computacionais são executadas (AVARRE et al., 2007; HE et al., 2012a; HE et al., 2012b; VAN NOSTRAND et al., 2012).

Desde a sua concepção o GeoChip vem passando por várias gerações. O GeoChip 1.0 foi construído com 763 sondas envolvidas no ciclo do nitrogênio (nirS, nirK, nifH, amoA), oxidação do metano (pmoA) e redução de sulfeto (dsrAB), além de 2.402 sondas envolvidas na biodegradação de contaminantes e resistência a metal (RHEE et al., 2004; TIQUIA et al., 2004) . Devido ao número limitado de sondas do GeoChip 1.0, foi desenvolvido o GeoChip 2.0 que apresentava 24.243 sondas, uma cobertura de 10.000 genes envolvidos em 150 categorias de genes funcionais associados aos ciclos do carbono, nitrogênio, enxofre, fósforo, resistência a metais e biodegradação (HE et al., 2007).

Em sua versão 3.0 o GeoChip foi construído com 28.000 sondas, uma cobertura de 57.000 genes e 292 famílias de genes funcionais além do emprego do oligonucleotídeo de referência padrão, para realizar processos de normalização e permitir comparação entre lâminas (HE et al., 2010). Em sua última versão o GeoChip 4.0 foi construído com oligonucleotídeos de 50 pares de base, com 120.054 sondas sendo que 36.072 sondas estão associadas ao microbioma humano, além disso possui uma cobertura de 200.000 genes distribuídos em 539 famílias e apresenta também genes associados à resposta ao stress, marcador filogenético gyrB e fatores de virulência (HE et al., 2012a). O Quadro 3 apresenta as principais sondas presentes na lâmina do GeoChip 4.0.

A nomenclatura para os diversos termos utilizados na análise dos resultados de GeoChip segue um padrão que iremos adotar aqui neste trabalho, onde: a) gene funcional é o termo usado para cada uma das sequências de genes presentes na lâmina do GeoChip; b) família de genes se refere a grupos de genes homólogos, que codificam enzimas da mesma família, independente do micro-organismo de origem; c) processo funcional indica o conjunto de famílias de genes que realizam o mesmo processo, como oxidação de metano e nitrificação; d) grupo de processos funcionais se refere a agrupamentos dos mesmos, como ciclo do carbono, do nitrogênio, etc. (PAULA, 2012).

No que se refere a genes associados à degradação de compostos orgânicos, o GeoChip 4.0 apresenta sondas relacionadas a biorremediação de compostos aromáticos, solventes clorados, herbicidas, pesticidas e outros compostos relacionados (HE et al., 2012b) e tem sido empregado com sucesso para caracterizar a diversidade de genes funcionais associados à biorremediação em ambientes como manguezais (PAES, 2008), solo (LIANG, Y. et al., 2009) e ambiente marinho (HAZEN et al., 2010). 
Quadro 3. Caracterização das sondas presentes na lâmina do GeoChip 4.0

\begin{tabular}{|llc|}
\hline Grupo de Processos Funcionais & Processo Funcional & $\begin{array}{c}\text { Número de Sondas de } \\
\text { Genes }\end{array}$ \\
\hline Ciclo do Carbono & Degradação de carbono & 9.033 \\
& Fixação de carbono & 1.762 \\
& Oxidação de metano & 240 \\
Ciclo do Enxofre & Produção de metano & 267 \\
Ciclo do Fósforo & Oxidação de enxofre & 468 \\
Ciclo do Nitrogênio & Redução dissimilatória do enxofre & 2.786 \\
& Utilização de Fósforo & 1.378 \\
& Oxidação anaeróbia de amônia & 49 \\
& Desnitrificação & 2.654 \\
& Fixação de Nitrogênio & 1.224 \\
& Mineralização & 999 \\
Nitrificação & 1.443 \\
Degradação de compostos orgânicos & Redução assimilatória do nitrogênio & 533 \\
Estresse & Redução dissimilatória do nitrogênio & 650 \\
Genes de bacteriófagos & & 17.919 \\
Marcador filogenético gyrB & & 21.574 \\
Processos energéticos & & 1.100 \\
Resistência a antibióticos & & 2.390 \\
Resistência a metais & & 862 \\
Virulência & & 3.349 \\
Outros & & 9.478 \\
Microbioma humano & & 3.732 \\
& & 102 \\
& & 36.072 \\
& & $\mathbf{1 2 0 . 0 5 4}$ \\
\hline
\end{tabular}

Fonte: Adaptado de He et al. (2012a)

No Brasil o primeiro estudo realizado para caracterização funcional de manguezais foi conduzido por Paes (2008) que utilizou o GeoChip 2.0 para análise da comunidade da Baía de Todos os Santos (BA) e os resultados obtidos indicaram 184 sequências gênicas na área contaminada e 233 na área preservada. Nesse trabalho os maiores números de genes detectados nas amostras foram associados ao processo de remediação orgânica.

É importante mencionar que o emprego do GeoChip para avaliar ambientes ainda pouco explorados quanto à diversidade funcional, como é o caso dos manguezais, pode revelar seu potencial funcional e ajudar a compreender os impactos causados pelos derramamentos de óleo e os genes associados à biodegradação dos hidrocarbonetos presentes nestes ambientes. 


\section{MATERIAL E METODOLOGIA EMPREGADA}

Para responder às perguntas propostas neste estudo utilizamos uma combinação de diferentes técnicas, que incluem análises físico-químicas das amostras de sedimento, análise da concentração dos hidrocarbonetos, cultivo de micro-organismos, extração de DNA, construção de bibliotecas gênicas, Sequenciamento pelo método de Sanger, PCR em tempo real, Pirosequenciamento e Microarranjos de DNA (GeoChip), conforme apresentado no organograma a seguir:

Figura 13. Organograma da metodologia empregada no presente estudo.

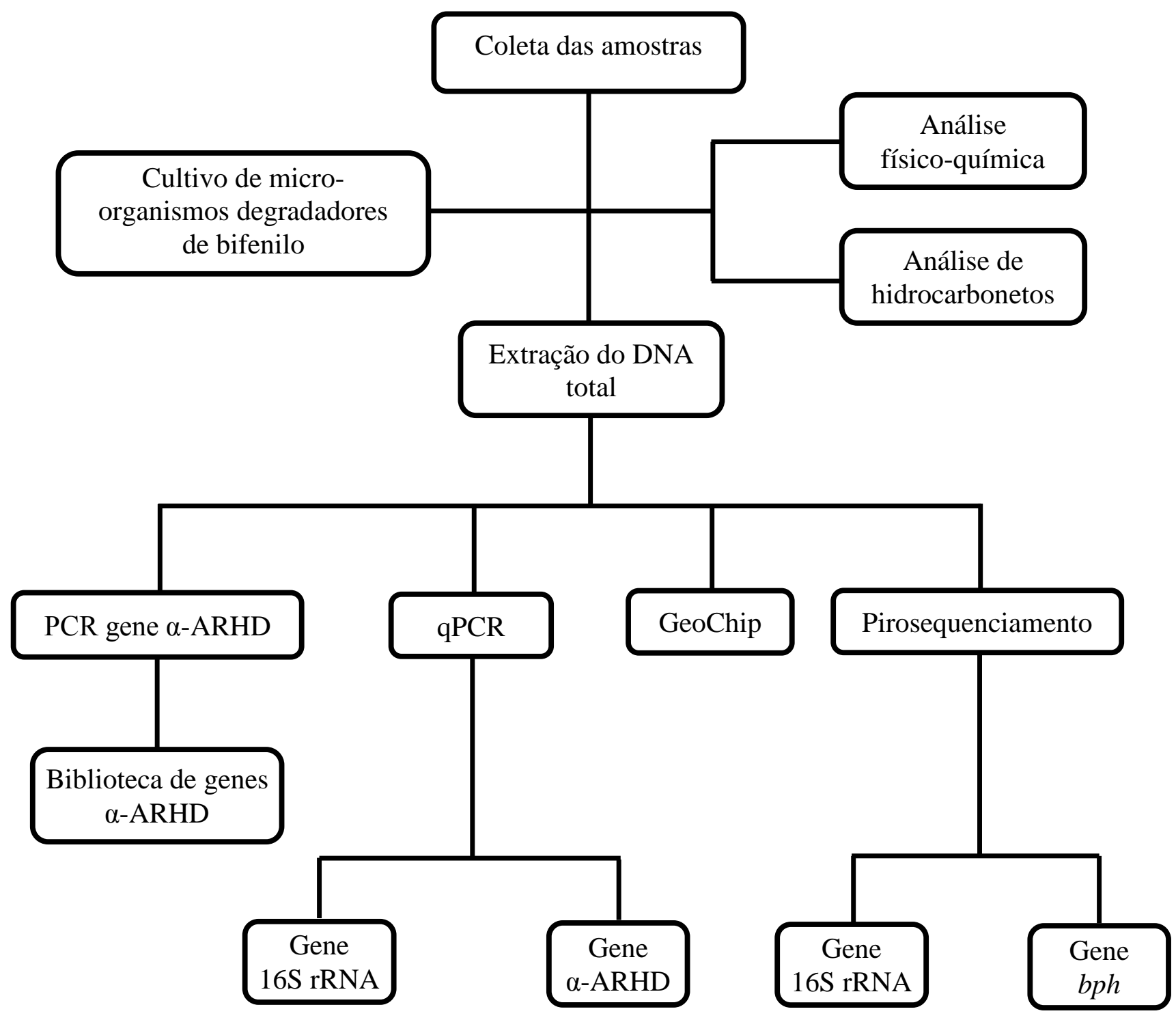




\section{1 Área de estudo e amostragem}

No presente estudo foram analisadas amostras de sedimentos de três áreas de manguezais localizados nas cidades de Bertioga e Cananéia no Estado de São Paulo (Quadro 4 e Figura 14). Estes manguezais foram escolhidos por representarem diferentes estágios de preservação e contaminação por hidrocarbonetos e resíduos de origem antrópica, conforme mencionado no item 3.2.

As amostras de sedimento foram coletadas no ano de 2.009 nos meses de agosto (Cananéia) e setembro (Bertioga), em período de maré baixa, à profundidade de 0 - $10 \mathrm{~cm}$ em triplicata em cada ponto em cada manguezal, totalizando 27 amostras (3 manguezais x 3 pontos x 3 repetições). Cada amostra constituiu-se de $50 \mathrm{~g}$ de sedimento, obtida por amostrador de $30 \mathrm{~cm}$ de comprimento, por $7 \mathrm{~cm}$ de diâmetro, que foi introduzido no sedimento dos manguezais. Optou-se pela profundidade de $0-10 \mathrm{~cm}$, pois é nesta região que ocorre a maioria das reações bacterianas dependentes de oxigênio, como a biossíntese e biodegradação de moléculas.

As amostras foram aliquotadas, sendo que aquelas utilizadas para quantificação dos HPAs foram armazenadas em recipientes de alumínio enquanto as destinadas à extração de DNA foram transferidas para sacos estéreis (Whirl Pack). Todas as amostras foram refrigeradas a $4{ }^{\circ} \mathrm{C}$ e transportadas para o Laboratório de Ecologia Microbiana do Instituto Oceanográfico - USP.

Quadro 4. Localização geográfica dos manguezais amostrados no Estado de São Paulo.

\begin{tabular}{|c|c|c|c|c|c|}
\hline \multirow{2}{*}{ Mangue } & \multirow{2}{*}{$\begin{array}{c}\text { Estágio de } \\
\text { Preservação }\end{array}$} & \multirow{2}{*}{ ID } & \multicolumn{2}{|c|}{ Localização } & \multirow{2}{*}{$\begin{array}{l}\text { Descrição do } \\
\text { Ponto }\end{array}$} \\
\hline & & & Latitude & Longitude & \\
\hline \multirow{3}{*}{ Bertioga } & \multirow{3}{*}{$\begin{array}{c}\text { Contaminação } \\
\text { antrópica }\end{array}$} & BA1 & S 235'ㄱ,9”' & $\mathrm{W} 46^{\circ} 15^{\prime} 6,0^{\prime}$ & P1- Curso d’água \\
\hline & & BA2 & S $23^{\circ} 54^{\prime} 6,8^{\prime \prime}$ & W $46^{\circ} 15^{\prime} 5,7^{\prime}$ & P2- Floresta \\
\hline & & BA3 & S $23^{\circ} 54^{\prime} 5,7^{\prime \prime}$ & W $46^{\circ} 15^{\prime} 5,4^{\prime}$ & P3- Restinga \\
\hline \multirow{3}{*}{ Bertioga } & \multirow{3}{*}{$\begin{array}{l}\text { Contaminação } \\
\text { por óleo }\end{array}$} & BC1 & S $23^{\circ} 53^{\prime} 50,4^{\prime \prime}$ & W 46 ${ }^{\circ} 12^{\prime} 30,6^{\prime \prime}$ & P1- Curso d'água \\
\hline & & BC2 & S $23^{\circ} 53^{\prime} 42,8^{\prime \prime}$ & $\mathrm{W} 46^{\circ} 12^{\prime} 30,1^{\prime}$ & P2- Floresta \\
\hline & & BC3 & S $23^{\circ} 53^{\prime} 41,1^{\prime}$ & W 46 12 '32,3’' & P3- Restinga \\
\hline \multirow{3}{*}{ Cananéia } & \multirow{3}{*}{ Preservado } & $\mathrm{CP} 1$ & S 250’ $1,8 ’$ & W $47^{\circ} 57^{\prime} 41,7^{\prime \prime}$ & P1-Curso d'água \\
\hline & & $\mathrm{CP} 2$ & S $25^{\circ} 05^{\prime} 6,8^{\prime \prime}$ & W $47^{\circ} 57^{\prime} 41,4^{\prime \prime}$ & P2- Floresta \\
\hline & & СР3 & S $25^{\circ} 05^{\prime} 12,6^{\prime \prime}$ & W 47º57’41,2'” & P3- Restinga \\
\hline
\end{tabular}


Figura 14. Esquema dos pontos de amostragem em cada manguezal analisado.
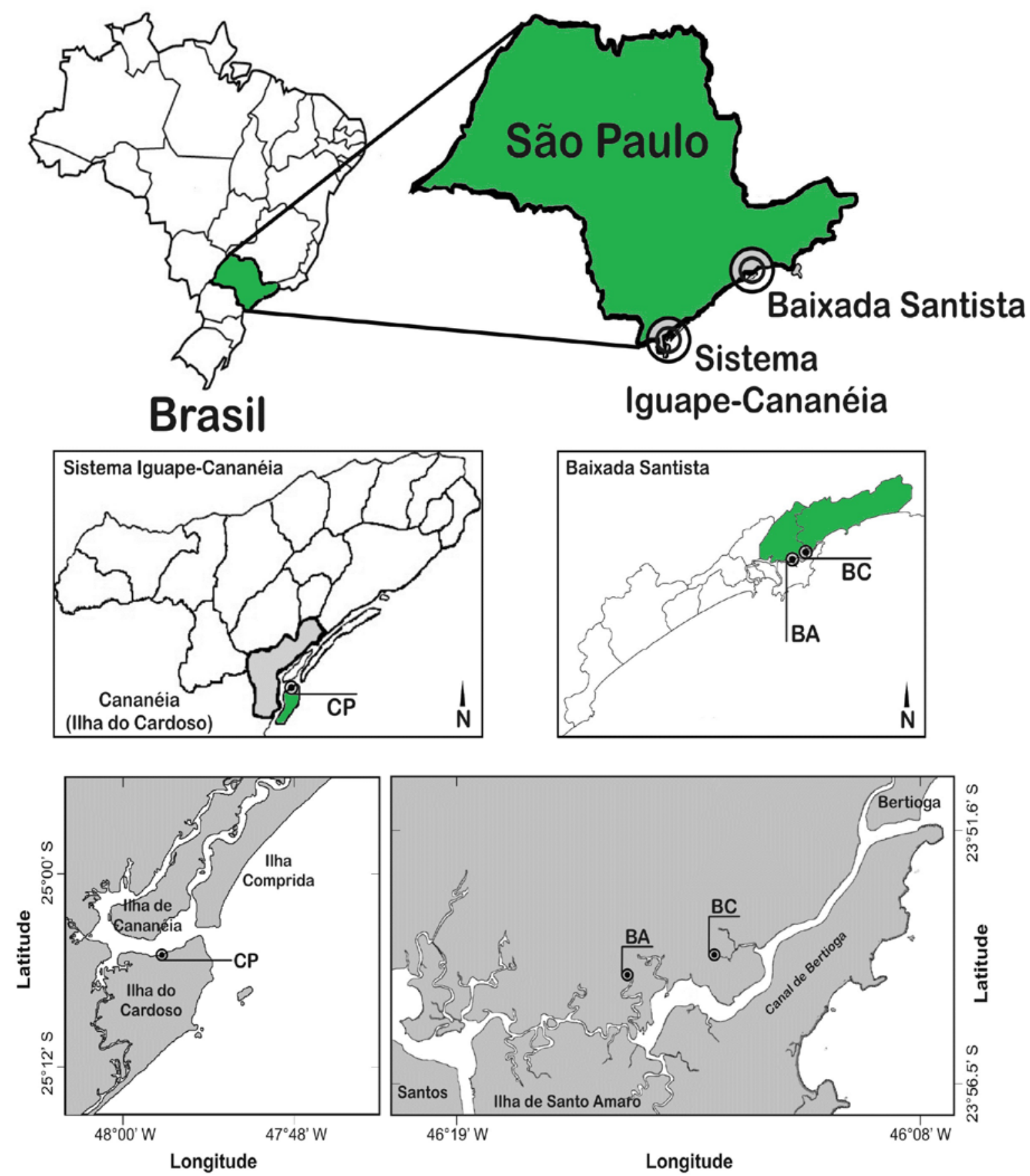

Ilustração: Dr. André Rosch Rodrigues (IO/USP)

\subsection{Análise dos parâmetros físico-químicos e medidas de Hidrocarbonetos}

As análises dos parâmetros físico-químicos foram realizadas na Escola Superior de Agricultura Luiz de Queiroz (ESALQ/USP) de acordo com a metodologia descrita por Van Raij (2001). Os parâmetros mensurados foram: umidade, areia:silte:argila, condutividade, 
matéria orgânica, nitrogênio $(\mathrm{N})$, fósforo $(\mathrm{P})$, potássio $(\mathrm{K})$, cálcio $(\mathrm{Ca})$, magnésio $(\mathrm{Mg})$, enxofre (S), sódio (Na). Estes dados já foram publicados e podem ser consultados no trabalho de Dias e colaboradores (2011). Os parâmetros físico-químicos dos sedimentos foram correlacionados com os diferentes manguezais por meio de análise multivariada (Análise de Componentes Principais), realizada no programa CANOCO 4.5 (BRAAK et al., 2002).

As análises de HPAs foram realizadas no Laboratório de Oceanografia Química do Instituto Oceanográfico - USP e seguiram a metodologia descrita Martins e colaboradores (2004). Brevemente $10 \mathrm{~g}$ de sedimento foram extraídos em Soxhlet com $80 \mathrm{~mL}$ de uma solução de $n$-hexano e diclorometano (1:1) por 8 horas. Foi utilizado um controle negativo (branco) para cada amostra analisada. A cada frasco de extração foi adicionado cobre e uma solução de padrões internos contendo: 0,4 $\mu$ g de aromáticos deuterados (naftaleno-d8 e acenafteno-d10 para HPAs com até dois anéis aromáticos; fenantreno-d10 para HPAs com três anéis aromáticos; criseno-d12 para HPAs com quatro e cinco anéis aromáticos, e perileno-d12 para HPAs com cinco e seis anéis aromáticos).

O extraído foi concentrado até $2 \mathrm{~mL}$ em um evaporador rotativo à vácuo e o volume restante foi submetido à cromatografia de absorção em uma coluna contendo $1,8 \mathrm{~g}$ de alumina e empacotada sobre 3,2 g de sílica-gel, 5 \% desativadas em peso com água livre de orgânicos, e sulfato de sódio. Eluiu-se a coluna com $20 \mathrm{~mL}$ de n-hexano (Fração 1) e $15 \mathrm{~mL}$ de uma solução 30 \% diclorometado em n-hexano (Fração 2).

A fração 2 foi concentrada para $1 \mathrm{~mL}$ em evaporador rotativo a vácuo e transferidas para ampolas calibradas. A fração 2 (F2) concentra os HPAs. A identificação e quantificação dos hidrocarbonetos aromáticos, contidos na F2 foi realizada através da injeção de $1 \mu \mathrm{L}$ da amostra em um cromatógrafo a gás (GC-FID) acoplado a um espectrômetro de massa (GCMS). O espectrômetro de massa foi da V.G. Masslab - Fisons modelo TRIO 1000. A corrida foi feita no modo MIS (Monitoring Ion System), sendo registrados apenas os picos relacionados aos fragmentos $(\mathrm{m} / \mathrm{z})$ característicos dos hidrocarbonetos aromáticos. Foi utilizada uma coluna capilar Chrompack DB-1, com $25 \mathrm{~m}$ de comprimento, 0,25 mm de diâmetro interno e fase estacionária de 100\% metil-silicona.

\subsection{Extração do DNA total das amostras de sedimento}

Para cada uma das 27 amostras de sedimento O DNA total foi extraído em triplicata a partir de 0,3 g de sedimento pela utilização do Power Soil ${ }^{T M}$ DNA Isolation Kit (MoBio), seguindo as instruções do fabricante. Um volume final de $25 \mu \mathrm{L}$ foi obtido para cada extração 
e a qualidade do DNA extraído foi analisada por eletroforese em gel de agarose 1,0\% $(\mathrm{g} / \mathrm{mL})$ em tampão TAE (Tris - Acetato - EDTA) $1 \mathrm{X}$ e padrão de peso molecular $\lambda$-HindIII (Invitrogen Life Technologies). Os géis de agarose foram submetidos a um campo elétrico de $100 \mathrm{~V}$ e posteriormente corados com brometo de etídio $(0,5 \mu \mathrm{g} / \mathrm{ml}$ de gel $)$, expostos em um transiluminador com luz UV, visualizados e fotografados no software de imagens Kodak 1D 3.6 (Kodak).

A concentração do DNA total de cada amostra foi verificada no espectrofotômetro NanoDrop ${ }^{\circledR}$ ND-1000 UV-Vis (Uniscience), onde também foram conferidos os valores das razões de absorbância 260/280 e 260/230 nm, que correspondem, respectivamente, a pureza em relação a concentração de sal e de proteínas presentes. O DNA total obtido em cada extração foi diluído para 20 ng/ $\mu \mathrm{L}$ e uma alíquota para uso foi preparada pela junção das triplicatas de extração.

\subsection{Amplificação do gene $\alpha$-ARHD}

Para a detecção e análise da diversidade do gene $\alpha$-ARHD, a partir do DNA total extraído das amostras de sedimento das regiões de manguezais, foi realizada a técnica de PCR convencional utilizado um conjunto de primers degenerados $\alpha$-ARHDf (TTY RYI TGY AII TAY CAY GGI TGG G) e $\alpha$-ARHDr (AAI TKY TCI GCI GSI RMY TTC CA) (BELICANTA, 2004). Esses primers amplificam um fragmento de 300 a 329 pb e foram desenhados baseados em regiões altamente conservadas das seqüências de aminoácidos da subunidade alfa das ARHDs.

Os genes foram amplificados a partir do DNA total obtido das 27 amostras de sedimento. A reação de amplificação do gene $\alpha$-ARHD consistiu na concentração de $1 \mathrm{X}$ do tampão de reação (20 mM Tris - $\mathrm{HCl} \mathrm{pH}$ 8,4; $50 \mathrm{mM} \mathrm{KCl);} \mathrm{1,5} \mathrm{mM} \mathrm{de} \mathrm{MgCl}_{2}$; 0,8 mM de dNTP's; 0,8 $\mu \mathrm{M}$ dos primers $\alpha$-ARHDf e $\alpha$-ARHDr e $1 \mathrm{U}$ de Platinum Taq DNA Polimerase (Invitrogen Life Technologies) em um volume final de 25 uL. O programa de amplificação consistiu de desnaturação inicial a $97{ }^{\circ} \mathrm{C}$ por 3 minutos; 35 ciclos de $94{ }^{\circ} \mathrm{C}$ por 1 minuto; 55 ${ }^{\circ} \mathrm{C}$ por 1 minuto; $72{ }^{\circ} \mathrm{C}$ por 1 minuto e extensão final de $72{ }^{\circ} \mathrm{C}$ por 5 minutos.

\subsubsection{Clonagem dos fragmentos amplificados}

Os produtos obtidos pela técnica de PCR para o gene $\alpha$-ARHD a partir do DNA proveniente das diferentes amostras foram analisados por eletroforese em gel de agarose 1,5\% 
(g/mL) em tampão TAE 1X e padrão de peso molecular 100pb DNA Ladder (Invitrogen Life Technologies). Os géis de agarose foram submetidos a um campo elétrico e corados conforme descrito no item 4.3.

Após a confirmação do tamanho esperado para os amplicons, os mesmos foram excisados do gel de agarose, purificados utilizando-se os kits QIAquick Gel Extraction Kit (Qiagen) e Purelink PCR Purification Kit (Invitrogen Life Technologies) e quantificados no espectrofotômetro NanoDrop ${ }^{\circledR}$ ND-1000 UV-Vis (Uniscience). Os produtos de PCR purificados foram reunidos por ponto amostral, totalizando-se nove amostras para clonagem.

A clonagem dos fragmentos foi realizada conforme as instruções do fabricante pela utilização do kit pGEM-Teasy Vector System (Promega). A reação de ligação inserto:vetor (3:1) foi realizada a $4{ }^{\circ} \mathrm{C}$, overnight. Dois microlitros da ligação inserto:vetor foram utilizados para transformar 50 uL de células competentes de E. coli JM109 (Promega). A transformação foi realizada por choque térmico e as células transformadas foram recuperadas em $950 \mu \mathrm{L}$ de meio SOC (Triptona 20,0 g/L, Extrato de Levedura 5,0 g/L, NaCl 0,58 g/L, $\mathrm{MgSO}_{4} .7 \mathrm{H}_{2} \mathrm{O}$ 2,46 g/L, $\mathrm{MgCl}_{2}$ 0,95 g/L) à incubação de $37{ }^{\circ} \mathrm{C}$ por 90 minutos. Em seguida, $100 \mathrm{uL}$ das células transformadas foram inoculadas por espalhamento com alça de vidro em placas de ágar Luria Bertani - LB (Triptona 10,0 g/L, Extrato de Levedura 5,0 g/L, NaC 15,0 g/L) contendo ampicilina (100 $\mu \mathrm{g} / \mathrm{mL})$, isopropyl $\beta$-D-thiogalactopyranoside [IPTG (50 $\mu \mathrm{g} / \mathrm{mL})$ ] e 5-bromo-4-chloro-3-indolyl $\beta$-D-galactopyranoside [X-Gal $(40 \mu \mathrm{g} / \mathrm{mL})$ ] e incubadas a $37{ }^{\circ} \mathrm{C}$ por 16 h. As colônias com coloração branca (clones positivos) foram repicadas novamente em ágar LB contendo ampicilina, IPTG e X-Gal (conforme descrito acima) e incubadas a $37{ }^{\circ} \mathrm{C}$ por 20 horas para confirmação das células transformadas e isolamento dos clones.

As colônias brancas, correspondentes aos possíveis clones positivos, foram transferidas individualmente (com o auxílio de palitos autoclavados) para placas de 96 poços contendo 50 $\mu \mathrm{L}$ de tampão TE $1 \mathrm{X}$. Estas placas foram então submetidas à temperatura de $95^{\circ} \mathrm{C}$ por 15 minutos em termociclador, para promover a lise celular. Um microlitro desse volume foi utilizado para confirmação da presença do inserto através da amplificação direta utilizando os primers M13F (5’ CGC CAG GGT TTT CCC AGT CAC GAC 3’) e M13R (5’ TTT CAC ACA GGA AAC AGC TAT GAC 3’) 0,3 $\mu \mathrm{M}$, tampão de reação $1 \mathrm{X}$ (20 mM Tris - HCl pH 8,4; $50 \mathrm{mM} \mathrm{KCl);} \mathrm{1,5} \mathrm{mM} \mathrm{de} \mathrm{MgCl}_{2} ; 0,8 \mathrm{mM}$ de dNTPs e $1 \mathrm{U}$ de Platinum Taq DNA Polimerase (Invitrogen Life Technologies) em um volume final de $25 \mathrm{uL}$. O programa de amplificação consistiu de desnaturação inicial a $97{ }^{\circ} \mathrm{C}$ por 3 minutos; 35 ciclos de $94{ }^{\circ} \mathrm{C}$ por 30 segundos; $60{ }^{\circ} \mathrm{C}$ por 30 segundos; $72{ }^{\circ} \mathrm{C}$ por 1 minuto, e extensão final de $72{ }^{\circ} \mathrm{C}$ por 5 
minutos. Após visualização em gel de agarose 1,5\%, os fragmentos de tamanho esperado para o gene $\alpha$-ARHD, que é o gene $\alpha$-ARHD (300-329 pb) adicionado da sequência amplificada do vetor (252 pb) foram purificados com o ZR-96 DNA Clean Up Kit (Zymo Research) e eluídos em $30 \mu \mathrm{L}$.

\subsubsection{Sequenciamento e análises filogenéticas}

Para o sequenciamento foi utilizado um primer interno do vetor: T7 (5' GTA ATA CGA CTC AC TAT AGG G 3') e os produtos foram sequenciados no Centro de Estudos do Genoma Humano da Universidade de São Paulo.

As seqüências nucleotídicas tiveram seus cromatogramas analisados e posteriormente a qualidade do sequenciamento foi averiguada através da ferramenta Phred, disponível online no software Eectropherogram quality analysis da EMBRAPA e as sequências com score $<10$ foram removidas. Em seguida essas sequências foram editadas manualmente usando o programa BioEdit (HALL, 1999) para remoção do vetor e dos primers. A seguir as seqüências foram comparadas com seqüências disponibilizadas no banco de dados GenBank do Centro de Informação Biotecnológica (NCBI), utilizando-se os algoritmos TBlastn e TBlastx (ALTSCHUL et al., 1990). As seqüências mais similares foram selecionadas como referências. Durante a seleção das seqüências referência foi dada prioridade àquelas cuja origem seja de isolados microbianos já descritos na literatura.

Posteriormente nossas seqüências nucleotídicas foram traduzidas in silico para aminoácidos utilizando o programa BioEdit, onde foi observada a correção das fases de leitura correspondentes às possíveis proteínas funcionais, para posterior alinhamento com as seqüências proteicas das referências.

O número de Famílias Proteicas Operacionais - OPFs (Operational Protein Families) foi determinado considerando-se as distâncias evolutivas de 0,03;0,05;0,10 e 0,20. A determinação do cutoff mínimo para separação de OPFs do gene $\alpha$-ARHD foi realizada através dos seguintes passos: (1) observação do número de famílias de ARHDs encontradas em cada biblioteca através da análise dos resultados obtidos no Tblastx (NCBI); (2) construção de árvores de similaridade, para cada biblioteca, a partir dos alinhamentos das seqüências dos clones e observação dos agrupamentos; (2) construção de matrizes de distância para cada biblioteca, no programa MOTHUR (SCHLOSS et al., 2009), e a partir desta matriz, rankings de abundância de seqüências foram determinados para cada intervalo de $1 \%$ de dissimilaridade. Observou-se que o número de famílias de ARHDs observadas no 
Tblastx e de agrupamentos nas árvores de similaridade, foram encontradas, em sua maioria, em um cutoff de 0,05.

Os índices de diversidade e riqueza das bibliotecas gênicas foram calculados pelo programa MOTHUR (SCHLOSS et al., 2009). Para cada biblioteca, foram calculados os índices de diversidade de Shannon ( $\left.H^{\prime}\right)$ e de Simpson, índices não paramétricos de estimativa de riqueza CHAO e ACE e curvas de rarefação. Os índices de riqueza compartilhada ou betadiversidade (sharedsobs, sharedace e sharedchao) foram calculados entre as amostras dos três manguezais. Também foram construídos diagramas de Venn (FAUTH et al., 1996) para verificar as intersecções e peculiaridades entre os ambientes, identificando o número de OPFs exclusivas e compartilhadas entre as amostras. O teste Libshuff foi utilizado para comparar a beta-diversidade entre as amostras e para verificar se estas são significativamente diferentes entre si.

A partir dos agrupamentos das seqüências baseado na similaridade de 95\% entre as seqüências do mesmo grupo (cutoff 0,05) foram escolhidas seqüências representantes para a construção da árvore filogenética juntamente com as seqüências de referência obtidas a partir do GenBank. O alinhamento foi realizado no programa Bioedit, utilizando a plataforma ClustalW (LARKIN et al., 2007) e os agrupamentos filogenéticos foram construídos no programa MEGA5 (TAMURA et al., 2011), pelo do método de Neighbor-Joining com modelo de substituição PAM (Dayhoff), bootstrap de 1.000 repetições e gaps foram considerados deleções par-a-par (pairwise deletion).

\subsection{Seleção de bactérias degradadoras de bifenilo}

A metodologia de enriquecimento e cultivo direto para obtenção de isolados degradadores de bifenilo (hidrocarboneto policíclico aromático), a partir das amostras de sedimento, foi realizada conforme a Figura 15.

Para o processo de enriquecimento foram construídos dois microcosmos para cada ponto amostral, utilizando frascos de cultivo tipo Schott de $100 \mathrm{ml}$ esterilizados nos quais foram adicionados $1000 \mu \mathrm{L}$ de bifenilo em solução com acetona (10 mg/L) como única fonte de carbono. O bifenilo foi pipetado na parede de ambos os frascos que foram mantidos em fluxo laminar até sua completa secagem. 
Figura 15. Protocolo elucidando as etapas da metodologia de enriquecimento

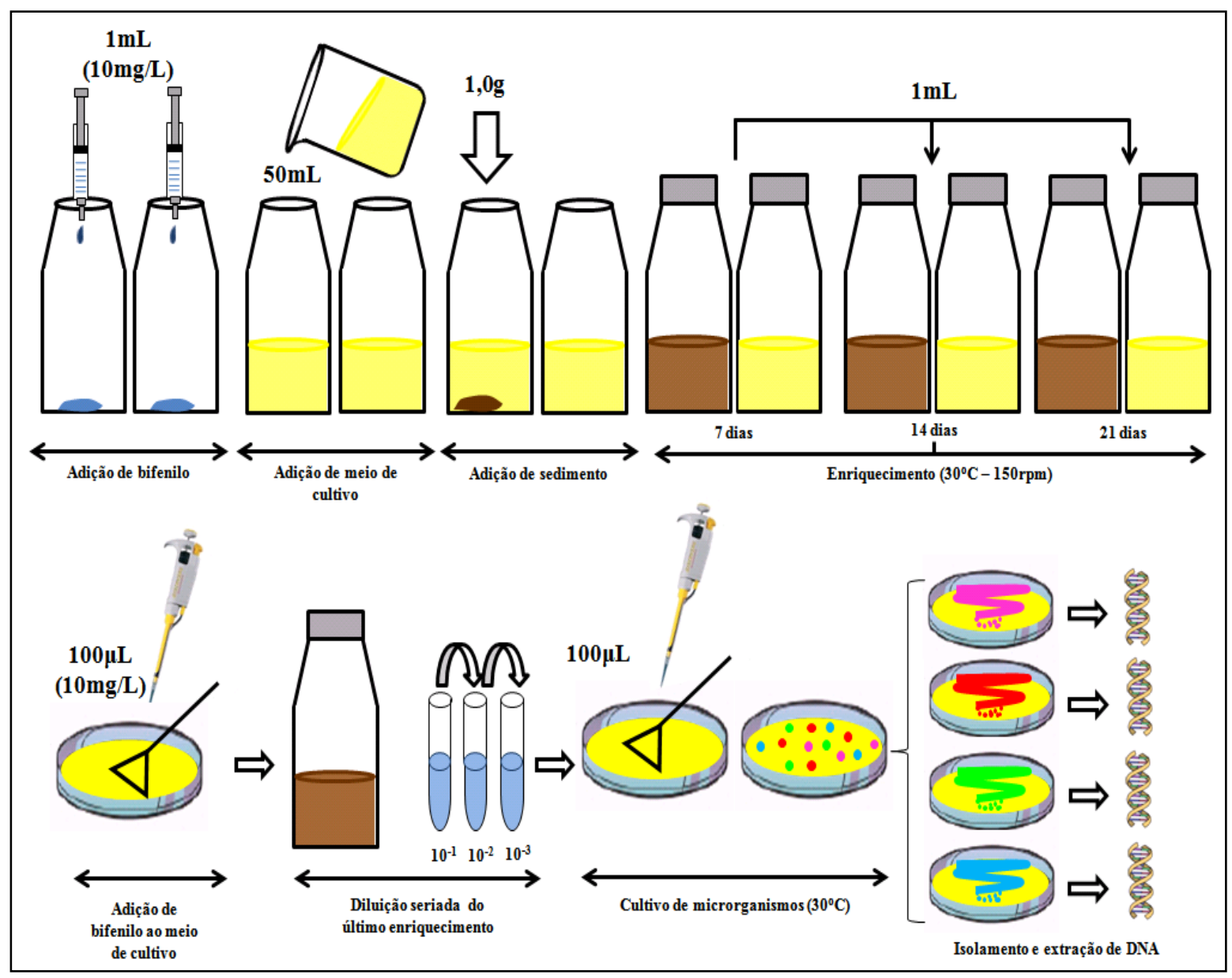

Após a formação dos cristais de bifenilo foram adicionados $50 \mathrm{~mL}$ de meio líquido Bushnell-Haas (BD - Becton, Dickinson and Company) em cada frasco e em um destes foi realizado um inóculo de $1,0 \mathrm{~g}$ de sedimento, sendo que o segundo frasco foi mantido como um controle negativo de crescimento. Ambos os frascos foram incubados a temperatura ambiente sob agitação constante de 150 rpm por 7 dias. Após esse período, um mililitro foi retirado de cada frasco para sub-cultivo e adicionado a um novo frasco contendo meio de cultura e bifenilo, nas mesmas condições citadas anteriormente por mais 7 dias.

O processo de enriquecimento foi repetido por três vezes e os frascos de cada um dos últimos repiques do enriquecimento foram amostrados para execução de diluição decimal seriada $\left(10^{-1}\right.$ a $\left.10^{-3}\right)$. Utilizamos uma alíquota de $0,1 \mathrm{~mL}$ da diluição $10^{-3}$ que foi semeada em triplicata em placas contendo meio de cultivo sólido Bushnell-Haas previamente acrescido de $0,1 \mathrm{~mL}$ de bifenilo $(10 \mathrm{mg} / \mathrm{L})$. Após incubação à temperatura de $30{ }^{\circ} \mathrm{C}$ e posterior crescimento das colônias, essas foram submetidas a um processo de isolamento até obtenção de culturas puras. A caracterização morfológica foi realizada através da observação macroscópica 
analisando tamanho, cor, aspecto e formato das colônias bacterianas presentes em cada placa e também pela observação microscópica pela coloração de Gram. Colônias que apresentaram características morfológicas e microscópicas únicas foram selecionadas para as análises moleculares.

\subsubsection{Identificação dos micro-organismos e análises filogenéticas}

A identificação de cada isolado que apresentou a capacidade de crescer na presença de bifenilo como única fonte de carbono foi realizada por método convencional de extração de DNA (WILSON, 2001) cuja qualidade foi analisada por eletroforese em gel de agarose 1,0\% (g/mL) em tampão TAE 1X e padrão de peso molecular $\lambda$-HindIII (Invitrogen Life Technologies). Os géis de agarose foram submetidos a um campo elétrico de $100 \mathrm{~V}$ e posteriormente corados com brometo de etídio $(0,5 \mu \mathrm{g} / \mathrm{ml})$, expostos em um transiluminador com luz $\mathrm{UV}$, visualizados e fotografados.

A concentração do DNA obtido de cada isolado foi verificada no espectrofotômetro NanoDrop ${ }^{\circledR}$ ND-1000 UV-Vis (Uniscience), onde também foram conferidos os valores das razões de absorbância 260/280 e 260/230 nm.

Para a identificação de cada isolado utilizamos os DNAs obtidos que foram submetidos à técnica de PCR convencional utilizado os primers 27F (AGA GTT TGA TCM TGG CTC AG) e 1401R (CGG TGT GTA CAA GGC CCG GGA ACG) que amplificam um fragmento de $1.400 \mathrm{pb}$.

A reação de amplificação do gene 16S rRNA consistiu na concentração de $1 \mathrm{X}$ do tampão de reação (20 mM Tris - $\mathrm{HCl} \mathrm{pH}$ 8,4; $50 \mathrm{mM} \mathrm{KCl);} 1,5 \mathrm{mM}$ de $\mathrm{MgCl}_{2} ; 0,8 \mathrm{mM}$ de dNTP's; 0,8 $\mu \mathrm{M}$ dos primers 27F e 1401R e 1U de Platinum Taq DNA Polimerase (Invitrogen Life Technologies) em um volume final de 25 uL. O programa de amplificação consistiu de desnaturação inicial a $97{ }^{\circ} \mathrm{C}$ por 3 minutos; 35 ciclos de $94{ }^{\circ} \mathrm{C}$ por 1 minuto; 55 ${ }^{\circ} \mathrm{C}$ por 1 minuto; $72{ }^{\circ} \mathrm{C}$ por 1 minuto e extensão final de $72{ }^{\circ} \mathrm{C}$ por 5 minutos.

Para o sequenciamento foi utilizado o primer 27F e os produtos foram sequenciados no Centro de Estudos do Genoma Humano da Universidade de São Paulo. As sequências nucleotídicas tiveram seus cromatogramas analisados e posteriormente foram editadas manualmente usando o programa BioEdit (HALL, 1999) para remoção dos primers. A seguir as seqüências foram comparadas com seqüências disponibilizadas no banco de dados do Ribosomal Database Project (RDP). As seqüências mais similares foram selecionadas como 
referências. Durante a seleção das sequências referência foi dada prioridade àquelas cuja origem seja de isolados microbianos já descritos na literatura.

O alinhamento múltiplo das sequências obtidas e das sequências referência foi realizado utilizando o software Bioedit (HALL, 1999). Posteriormente uma árvore filogenética foi construída com a utilização do programa MEGA 5 (TAMURA et al., 2011), através do método Neighbor-Joining e valor de bootstrap de 1.000 repetições.

\subsection{Quantificação dos genes 16S rRNA e $\alpha$-ARHD por PCR em tempo real}

A técnica de PCR em tempo real foi padronizada e utilizada neste estudo para quantificação absoluta do número de cópias dos genes 16S rRNA e $\alpha$-ARHD nas amostras estudadas. As reações para as 27 amostras e curva-padrão foram preparadas em duplicata e para tanto foram utilizadas placas de 96 poços e um volume final de $15 \mathrm{uL}$ contendo 7,5 $\mu \mathrm{L}$ do Kit SYBR ${ }^{\circledR}$ Green $^{\mathrm{TM}}$ qPCR Reagent System (Invitrogen Life Technologies), 1 uL de cada primer e $2 \mu \mathrm{L}$ do DNA molde. As quantificações foram realizadas na Genomics Core Research Technology Support Facility (RTSF) da Michigan State University utilizando o termociclador 7.900 HT - Real Time PCR System (Applied Biosystems).

Para a quantificação dos genes-alvo foram construídas curvas-padrão, realizando amplificações com um número de cópias conhecidas dos DNAs de referência, adicionadas nas reações em diluições seriadas. Desta forma, os dados da amplificação dos DNAs de referência (Ct - cycle threshold) foram usados como normalizadores, para determinar o número de cópias do gene de interesse passível de amplificação em cada amostra avaliada. A amplificação das diferentes diluições do DNA de referência também resultou na geração de dados de correlação logarítmica $\left(\mathrm{R}^{2}\right)$ e eficiência de amplificação entre o número de ciclos e a quantidade de DNA nas amostras.

Os DNAs de referência, preparados em diluições seriadas para a construção da curvapadrão para cada gene variaram de $10^{8}$ a $10^{4}$ cópias do gene/ $\mu \mathrm{L}$ de solução para o gene $16 \mathrm{~S}$ rRNA e $10^{6}$ a $10^{2}$ cópias do gene/ $\mu \mathrm{L}$ para o gene $\alpha$-ARHD. O cálculo do número de cópias para cada gene foi realizado conforme instruções da fabricante do equipamento de qPCR (Applied Biosystems) seguindo-se a fórmula:

Concentração de DNA $(\mathrm{g} / \mu \mathrm{L}) \times\left(6,022 \times 10^{23}\right)=$ número de cópias $/ \mu \mathrm{L}$ de solução

Tamanho do fragmento em $\mathrm{pb}$ x $649 \mathrm{~g} / \mathrm{mol}$

6,022 x $10^{23}=$ número de moléculas em 1 mol (número de Avogadro) $649 \mathrm{~g} / \mathrm{mol}=$ peso molecular médio de 1 par de base de DNA 
Para construção da curva-padrão e quantificação do gene 16S rRNA utilizamos como referência o DNA genômico da linhagem Burkholderia xenovorans LB400, considerando que tal micro-organismo possui 6 cópias do gene com 9.76 Mpb (CHAIN et al., 2006). Os primers universais utilizados para a quantificação foram 1132F e 1108R que amplificam um fragmento de 160 pb (LEIGH et al., 2007).

A curva-padrão para a quantificação do gene $\alpha$-ARHD foi realizada utilizando DNA plasmidial como referência. Para a obtenção do DNA plasmidial foram inicialmente realizadas amplificações utilizando os primers $\alpha$-ARHDf e $\alpha$-ARHDr e o DNA genômico de Burkholderia xenovorans LB400. Os produtos de PCR obtidos foram submetidos a gel de agarose $1,5 \%(\mathrm{~g} / \mathrm{mL})$, reunidos, purificados e clonados em cepas de Escherichia coli JM109 (Promega), utilizando-se o Kit pGEM-Teasy Vector System (Promega), conforme mencionado no item 4.4.1.

As colônias que foram confirmadas quanto à presença do inserto, través da amplificação direta da célula transformada com os primers $\alpha$-ARHDf e $\alpha$-ARHDr, foram transferidas para meio de cultura LB com ampicilina $(100 \mu \mathrm{g} / \mathrm{mL})$ e incubadas por 16 horas a $35{ }^{\circ} \mathrm{C}$, posteriormente fez-se a extração do DNA plasmidial utilizando-se o Kit Wizard Plus SV Minipreps DNA Purification System (Promega). Os produtos resultantes das extrações de pasmídeos foram reunidos, quantificados no espectrofotômetro NanoDrop ${ }^{\circledR}$ ND-1000 UV-Vis (Uniscience) e utilizados como referência para a construção da curva-padrão.

Os protocolos e condições utilizadas para o ensaio quantitativo com as amostras ambientais foram as mesmas descritas para a construção da curva-padrão (Quadro 5), variando apenas as concentrações de DNA-molde para a quantificação de cada gene em cada amostra. Em todas as reações, uma curva de desnaturação foi realizada ao final, com temperatura variando de $60{ }^{\circ} \mathrm{C}$ a $95{ }^{\circ} \mathrm{C}$ para verificar a especificidade de amplificação pela observação de picos únicos.

A eficiência da reação para cada gene foi calculada seguindo a fórmula:

$$
E=\left(10^{-1 / a}\right)-1
$$

$\mathrm{E}=$ eficiência da reação;

$\mathrm{a}=$ inclinação da reta obtida pela fórmula $\mathrm{y}=\mathrm{ax}+\mathrm{b}$

As análises estatísticas foram realizadas na plataforma R 2.12.1 com o pacote Stats (R DEVELOPMENT CORE TEAM, 2010). Anova one-way, com posterior teste de Tukey, foram empregados para verificar diferenças na abundância dos genes 16S rRNA e $\alpha$-ARHD entre os pontos de amostragem. 
Quadro 5. Informações sobre a reação de qPCR para os genes 16S rRNA e $\alpha$-ARHD.

\begin{tabular}{|c|c|c|}
\hline \multirow[b]{2}{*}{ Características da qPCR } & \multicolumn{2}{|c|}{ Gene } \\
\hline & 16S rRNA & $\alpha$-ARHD \\
\hline Tipo de DNA & Genômico (9.76 Mbp) & Plasmidial (3.01 Kpb) \\
\hline Primer utilizado & $1132 \mathrm{~F}$ e $1108 \mathrm{R}$ & ARHDf e ARHDr \\
\hline Fragmento amplificado & $160 \mathrm{pb}$ & $300 \mathrm{pb}$ \\
\hline Diluições seriadas (Curva padrão) & $10^{8}$ a $10^{4}$ cópias/uL & $10^{6}$ a $10^{2}$ cópias/uL \\
\hline Concentração do primer & $0,2 \mathrm{uM}$ & $0,8 \mathrm{uM}$ \\
\hline Concentração das amostras & 20 ng/ul (diluído 100x) & $10 \mathrm{ng} / \mathrm{uL}$ \\
\hline Condições de amplificação & $\begin{array}{l}50{ }^{\circ} \mathrm{C}-2 \mathrm{~min} \\
95{ }^{\circ} \mathrm{C}-10 \mathrm{~min} \\
95{ }^{\circ} \mathrm{C}-15 \operatorname{seg}(40 \mathrm{x}) \\
60{ }^{\circ} \mathrm{C}-1 \mathrm{~min}\end{array}$ & $\begin{array}{l}50{ }^{\circ} \mathrm{C}-2 \mathrm{~min} \\
95{ }^{\circ} \mathrm{C}-2 \mathrm{~min} \\
94{ }^{\circ} \mathrm{C}-30 \mathrm{seg} \\
55{ }^{\circ} \mathrm{C}-45 \operatorname{seg}(40 \mathrm{x}) \\
72{ }^{\circ} \mathrm{C}-45 \operatorname{seg} \\
72{ }^{\circ} \mathrm{C}-5 \mathrm{~min}\end{array}$ \\
\hline
\end{tabular}

\subsection{Pirosequenciamento}

O pirosequenciamento para os genes 16S rRNA e bph foi realizado na Genomics Core Research Technology Support Facility (RTSF) da Michigan State University (MSU). Para este propósito foi utilizado o sequenciador automático Genome Sequencer FLX System (454 Life Sciences) com a plataforma GS FLX Titanium. As reações de PCR para pirosequenciamento foram preparadas para um volume total de $20 \mu \mathrm{L}$, contendo 1X FastStart High Fidelity Reaction Buffer (Roche Diagnostics), 1,0 $\mu \mathrm{M}$ de cada primer, $150 \mathrm{ng} / \mu \mathrm{L}$ de BSA (Bovine Serum Albumin, BioLabs), 0,2 mM de dNTPs, 0,5 $\mu \mathrm{L}$ (2,5 U) de FastStart High Fidelity PCR System Enzyme Blend (Roche Diagnostics) e 20 ng de DNA molde.

Os primers 557f e 926r utilizados neste estudo para amplificação de um fragmento de 349 pb do gene 16S rRNA foram desenhados pela equipe do Ribosomal Database Project RDP e amplificam uma porção altamente conservada que flanqueia a região V4 do rRNA. Os primers foram selecionados por apresentarem: (i) um apropriado comprimento dos amplicons para o pirosequenciamento com a plataforma GS FLX Titanium, (ii) alta cobertura para primers universais com enfoque no domínio Bacteria, (iii) alta resolução e acurácia para 
classificação e identificação bacteriana, e (iv) baixa frequência de inserções e deleções para simplificar o alinhamento das sequências (SUL et al., 2011).

A amplificação do gene bph foi realizada utilizando-se os primers BPH-f3 e BPH-r1 descritos por Iwai et al. (2010), que amplificam uma fração de aproximadamente 452 pb da subunidade alfa de dioxigenases aromáticas. Para o desenho dos primers os autores selecionaram seqüências a partir do banco de dados do FunGene - Funcional Gene Pipeline \& Repository (http://fungene.cme.msu.edu/), de genes de dioxigenases da família tolueno/bifenilo ( $b p h)$, utilizando valores de score maiores que 900 e tamanho de seqüências superiores a $400 \mathrm{pb}$.

No processo de síntese de ambos os conjuntos de primers foram adicionados adaptadores A (primer forward) e B (primer reverso) e, além do adaptador, o primer forward utilizado para cada amostra foi sintetizado com um código de identificação (tag) composto por 10 bases nucleotídicas, posteriormente utilizadas para reconhecimento da origem amostral de cada uma das sequências obtidas. A descrição das sequências nucleotídicas dos adaptadores, tags e primers estão mencionadas no Quadro 6.

Para ambos os genes a reação de PCR foi realizada em triplicata para cada uma das 27 amostras conforme a descrição a seguir: a) 3 minutos a $94{ }^{\circ} \mathrm{C}$, seguido de 30 ciclos de 30 segundos a $94{ }^{\circ} \mathrm{C}, 30$ segundos a $56{ }^{\circ} \mathrm{C}$ e 1 minuto a $72{ }^{\circ} \mathrm{C}$, com extensão final de 7 minutos a $72{ }^{\circ} \mathrm{C}$ para o gene $16 \mathrm{~S}$ rRNA e b) 3 minutos a $95{ }^{\circ} \mathrm{C}$, seguido de 30 ciclos de 45 segundos a 95 ${ }^{\circ} \mathrm{C}$, 45 segundos a $60{ }^{\circ} \mathrm{C}$ e 40 segundos a $72{ }^{\circ} \mathrm{C}$, além de extensão final de 4 minutos a $72{ }^{\circ} \mathrm{C}$ para o gene $b p h$.

Como controle positivo para as reações de amplificação foi utilizado o DNA total de uma comunidade microbiana artificial (mock community), que compreende uma amostra de DNA onde se conhece a proporção do gene em estudo. Neste caso, foi utilizada uma amostra equimolar contendo o DNA genômico das estirpes Burkholderia xenovorans LB400, Rhodococcus sp. RHA1 e Arthrobacter sp. B1B que contêm tanto o gene 16S rRNA quanto o gene para degradação de bifenilo $(b p h)$.

Após a realização da técnica de PCR os produtos de amplificação foram analisados por eletroforese em gel de agarose 1,5\% (g/mL), submetidos a um campo elétrico de $90 \mathrm{~V}$ por aproximadamente 30 minutos, depois corados com Sybr Safe $(1 \mu \mathrm{g} / 100 \mathrm{~mL})$ e comparados com um padrão de peso molecular de 100pb DNA Ladder (Invitrogen Life Technologies). Após a confirmação do tamanho esperado para os amplicons, os mesmos foram recortados do gel de agarose e purificados utilizando-se os kits: QIAquick Gel Extraction Kit (Qiagen) e QIAquick PCR Purification Kit (Qiagen). As concentrações do material purificado foram 
determinadas em espectrofotômetro NanoDrop ${ }^{\circledR}$ ND-1000 UV-Vis (Uniscience), os produtos foram então diluídos para a concentração de $20 \mathrm{ng} / \mathrm{uL}$ e posteriormente reunidos por ponto amostral, totalizando nove amostras submetidas ao pirosequenciamento para cada gene analisado.

As sequências obtidas para ambos os genes foram inicialmente analisadas quanto à qualidade de nucleotídeos pelo software do próprio equipamento (Genome Sequencer FLX System, 454 Life Sciences), que descarta as leituras de baixa qualidade. As sequências foram então copiadas do servidor Finch Server (http://finch.bch.msu.edu/Finch/) e submetidas às demais análises.

\subsubsection{Pirosequenciamento do gene 16S rRNA}

Os processos de filtragem e obtenção das sequências válidas geradas a partir do pirosequenciamento para o gene 16S rRNA foram realizados utilizando as ferramentas disponíveis no Ribosomal Database Project - RDP (http://pyro.cme.msu.edu/). A seleção inicial das sequências válidas foi realizada pela utilização da ferramenta Pyrosequencing Pipeline Initial Processor, considerando a presença das tags e do primer forward e os parâmetros padrões de filtro, e um comprimento mínimo de 300 pb. As sequências foram separadas por ponto de coleta, pelas suas tags de identificação e posteriormente os primers e tags foram removidos. A partir do uso dessa ferramenta foi possível obter: (a) o número total de sequências obtidas por tag, (b) o número de sequências que passaram pelos filtros e (c) um histograma com a média de comprimento das sequências para cada ponto amostral. A presença de quimeras foi detectada pelo uso da ferramenta online decipher disponível em http://decipher.cee.wisc.edu/FindChimeras.html.

Após o controle de qualidade inicial as sequências restantes foram submetidas ao alinhamento, pelo uso da ferramenta Aligner. Esta ferramenta alinha as sequências obtidas usando o alinhamento INFERNAL - INFERence of RNA ALignment (NAWROCKI et al., 2009), que permite uma maior correção de erros de sequenciamento e contorna alguns problemas de alinhamentos incorretos. Quando o alinhamento está completo o arquivo gerado fornece: (a) o total de sequências submetidas ao alinhamento, (b) o modelo utilizado (bactéria ou arqueia), (c) o modelo de sequência-referência (Escherichia coli J01695), (d) número de sequências contendo somente gaps, (e) um histograma apresentando a média do comprimento das sequências (mensurado em comparação à posição inicial e final da sequência usada como referência). As sequências alinhadas foram posteriormente submetidas à associação 
taxonômica em comparação àquelas depositadas no banco de dados do RDP e a ferramenta utilizada para a obtenção dessas informações foi o RDPMulticlassifier.

Foi realizada a análise de cluster utilizando o pacote Stats do programa R versão 2.12.1 (R DEVELOPMENT CORE TEAM, 2010) para verificar como as amostras se agrupavam, considerando a abundância de filos observada para cada ponto amostral. Com os valores de abundância, foi construído um dendograma de cores, utilizando a função heatmap, onde a intensidade da cor é proporcional à abundância dos filos. Os valores foram normalizados para cada filo, com média zero e desvio padrão igual a um. Considerando os perfis de intensidades de cores apresentados por cada amostra, foi realizada a análise de agrupamento hierárquico pelo método de complete linkage, baseado na distância euclidiana entre as amostras. Também utilizamos o programa CANOCO 4.5 (BRAAK \& SMILAUER, 2002) para uma análise multivariada, considerando os dados bióticos e abióticos de cada ponto amostral.

Os índices de diversidade e estimativas de riqueza foram calculados pelo uso do programa MOTHUR (SCHLOSS et al., 2009). Para cada biblioteca, foram calculados os índices de diversidade de Shannon ( $\left.H^{\prime}\right)$ e de Simpson, índices não paramétricos de estimativa de riqueza CHAO e ACE e curvas de rarefação. Os índices de riqueza compartilhada ou betadiversidade (sharedsobs, sharedace e sharedchao) foram calculados entre as amostras dos três manguezais. Também foram construídos diagramas de Venn (FAUTH et al., 1996) para verificar as intersecções e peculiaridades entre os ambientes, identificando o número de OTUs exclusivas e compartilhadas entre as amostras. O teste Libshuff foi utilizado para comparar a beta-diversidade entre as amostras e para verificar se estas são significativamente diferentes entre si.

\subsubsection{Pirosequenciamento do gene bph}

Os processos de filtragem e obtenção das sequências válidas geradas a partir do pirosequenciamento para o gene $b p h$ foram realizados utilizando as ferramentas disponíveis no Funcional Gene Pipeline \& Repository - FunGene (http://fungene.cme.msu.edu), de maneira bastante semelhante àquela realizada para o gene 16S rRNA no Ribosomal Database Project. Inicialmente, as amostras foram filtradas utilizando-se como parâmetros a presença do primer forward e das tags utilizadas, além de comprimento mínimo das sequências de 400pb. Primers e tags foram retirados e as sequências que passaram por este processo inicial de controle foram checadas quanto à presença de quimeras pelo uso da ferramenta online decipher disponível em http://decipher.cee.wisc.edu/FindChimeras.html. 
Quadro 6. Sequências nucleotídicas dos primers utilizados na realização da PCR para o pirosequenciamento de cada amostra.

\begin{tabular}{|c|c|c|c|c|c|c|c|}
\hline \multirow[b]{2}{*}{ ID } & \multirow[b]{2}{*}{ Adaptador } & \multicolumn{3}{|c|}{ Gene 16S rRNA } & \multicolumn{3}{|c|}{ Gene bph } \\
\hline & & $\begin{array}{l}\text { Sequência } \\
\text { da tag }\end{array}$ & $\begin{array}{c}\text { Sequência do Primer } \\
\text { (5'- 3') }\end{array}$ & ID & $\begin{array}{l}\text { Sequência } \\
\text { da tag }\end{array}$ & $\begin{array}{c}\text { Sequência do Primer } \\
\text { (5'- 3') }\end{array}$ & ID \\
\hline BA2 & A & acgtctcatc & & 577f MID_78 & tcgcagacac & & BPHf3 MID_108 \\
\hline BA3 & A & actcatctac & & 577f MID_79 & agactcagcg & & BPHf3 MID_116 \\
\hline BC3 & A & agcgactagc & 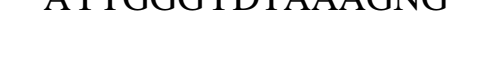 & 577f MID_82 & tgctatagac & 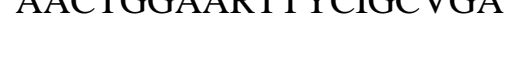 & BPHf3 MID_112 \\
\hline CP1 & A & agtagtgatc & & 577f MID_83 & tgctcgctac & & BPHf3 MID_113 \\
\hline CP2 & A & agtgacacac & & 577f MID_84 & agctatcgcg & & BPHf3 MID_118 \\
\hline СР3 & A & agtgtatgtc & & 577f MID_85 & agtctgactg & & BPHf3 MID_119 \\
\hline
\end{tabular}

MC = mock community

Sequência nucleotídica do Adaptador A: CGTATCGCCTCCCTCGCGCCATCAG (primer Forward)

Sequência nucleotídica do Adaptador B: CTATGCGCCTTGCCAGCCCGCTCAG (primer Reverso)

Fonte: Lima (2012). 
Posteriormente as sequências resultantes foram traduzidas in silico para a sequência de aminoácidos correspondente. Em seguida, os erros em relação às fases de leitura das possíveis proteínas foram corrigidos utilizando-se a ferramenta FrameBot. Esta ferramenta permite que sejam selecionadas sequências de proteínas representativas de genes catabólicos, neste caso, do banco de dados do gene bph depositadas no FunGene, para serem utilizadas na comparação entre as sequências resultantes do pirosequenciamento e correção das fases de leitura.

O RDP FrameBot produz um alinhamento entre as sequências do pirosequenciamento e as do banco de dados. Somente os alinhamentos que produziram as melhores pontuações (scores) foram utilizados e reportados como sequências válidas, e como filtros foram ainda utilizados os parâmetros de porcentagem de identidade (>70\%) e de comprimento de sequência no alinhamento (>130 aminoácidos).

Em seguida, as sequências que passaram pelos filtros anteriores foram alinhadas utilizando-se a ferramenta HMMER3 aligner, para a validação das sequências como possíveis proteínas funcionais. Foi gerado um histograma contendo as posições de início e fim dos alinhamentos em relação à sequência de referência.

Da mesma forma como foi realizado para o gene 16S rRNA, o heatmap foi realizado usando o programa R (R DEVELOPMENT CORE TEAM, 2010), uma Análise de Componentes Principais foi realizada utilizando o programa CANOCO 4.5 (BRAAK \& SMILAUER, 2002) e os índices de diversidade e riqueza, bem como as curvas de rarefação, índices de riqueza compartilhada, diagramas de Venn e teste Libshuff foram calculados para o gene bph pelo uso do programa MOTHUR (SCHLOSS et al., 2009).

\subsection{Técnica de Microarranjo de DNA - GeoChip}

Os ensaios relacionados com a detecção de genes funcionais das amostras em estudo foram realizados pelo uso de microarranjos de DNA - GeoChip. As lâminas utilizadas no presente estudo foram disponibilizadas pela equipe do Dr. Zihoung Zhou, através de uma parceria entre o Department of Botany and Microbiology, Institute for Environmental Genomics, University of Oklahoma e o grupo liderado pelo Dr. James Tiedje do Center for Microbial Ecology, da Michigan State University.

Para a realização desta técnica o DNA total das 27 amostras foi concentrado para 1,5 ug ( $\geq 150 \mathrm{ng} / \mathrm{uL}$ ) pela utilização do kit Genomic DNA Clean and Concentrator (Zymo Research 
Corporation, Irvine, CA, USA), seguindo as instruções do fabricante. Como padrões de pureza também foram consideradas as razões 260/260 e 260/230 superiores a 1,8.

O DNA foi marcado com o corante fluorescente cianina 3 (Сy-3), pelo método descrito por Wu et al. (WU et al., 2006) como apresentado a seguir: o DNA foi desnaturado a $99{ }^{\circ} \mathrm{C}$ por 5 minutos, na presença de $15 \mu \mathrm{g}$ de iniciadores randômicos (Invitrogen, Grand Island, NY, USA), e imediatamente resfriado e mantido em gelo. Posteriormente adicionou-se uma solução contendo desoxiribonucleotídios (dAGC-TP $5 \mathrm{mM}$, dTTP 2,5 mM), fragmento de Klenow 40 U (Invitrogen, Grand Island, NY, USA) e corante Cy-3 dUTP 25 nM. A solução teve seu volume final ajustado para $50 \mu \mathrm{L}$ com água miliQ e em seguida foi incubada por 6 horas a $37^{\circ} \mathrm{C}$, seguido por 3 minutos a $95^{\circ} \mathrm{C}$.

O DNA marcado foi purificado com o kit QIAquick (Qiagen, Valencia, CA, USA), de acordo com as instruções do fabricante, e a incorporação do corante foi checada no espectrofotômetro Nanodrop. Após confirmar a incorporação de aproximadamente 100 pmol de Cy-3, o DNA teve seu volume reduzido no equipamento Speed Vac (ThermoSavant, Milford, MA) a $45{ }^{\circ} \mathrm{C}$ por 45 minutos e armazenados a $-80{ }^{\circ} \mathrm{C}$ ao abrigo da luz até o uso.

O DNA marcado foi re-hidratado com 7,32 $\mu \mathrm{L}$ de solução de hibridização contendo: formamida 50\% (J.T. Baker, Philipsburg, NJ, USA); tampão SSC 5X (Ambion, Austin, TX, USA); SDS $0,1 \% ; 2,68 \mu \mathrm{L}$ de controles de rastreamento tracking-control (oligonucleotídeos de 48 pb, marcados com Cy3, que hibridizam com sondas controles na lâmina do GeoChip e rastreiam possíveis contaminações entre amostras; Roche NimbleGen, Madison, WI, USA); 3 $\mu \mathrm{L}$ de padrão universal (oligonucleotídeos, marcados com Cy-5, que se ligam a sondas específicas distribuídas uniformemente por toda a lâmina, utilizadas para normalizar a intensidade de sinal dos spots positivos das amostras; desenhado no Institute for Environmental Genomics, University of Oklahoma); e oligonucleotídeos de alinhamento da imagem para Cy-3 (0,17 $\mu \mathrm{L})$ e Cy-5 (0,28 $\mu \mathrm{L})$ (Roche NimbleGen, Madison, WI, USA). Após agitar em vortex, o DNA em solução foi aquecido a $95{ }^{\circ} \mathrm{C}$ por 5 minutos e mantido a $50{ }^{\circ} \mathrm{C}$ até a aplicação na lâmina de microarranjo, a qual foi pré-aquecida a $42{ }^{\circ} \mathrm{C}$. Para a hibridização, empregou-se a versão 4.3 do GeoChip. A hibridização foi realizada a $42{ }^{\circ} \mathrm{C}$, por 16 horas, na estação de hibridização Maui (BioMicro Systems, Madison, WI, USA).

Após a hibridização, as lâminas foram lavadas com o kit NimbleGen Wash Buffer (Roche NimbleGen, Madison, WI, USA). Soluções de $30 \mathrm{~mL}$ dos tampões de lavagem foram previamente preparadas e em seguida adicionado Dithiothreitol 0,1 $\mu \mathrm{M}$ (DTT; NimbleGen, Madison, WI, USA). As lâminas foram incubadas sequencialmente com os tampões I, II e III, 
por 2 minutos, 1 minuto e 15 segundos, respectivamente, sob agitação constante. Finalmente, as lâminas foram secadas em centrífuga para lâminas.

A captura da imagem de hibridização das lâminas foi realizada no scanner NimbleGen MS200 (Roche, Madison, WI, USA). O programa NimbleScan 2.5 foi usado para alinhamento das imagens, obtidas na leitura de Cy-3 (amostras), e Cy-5 (padrão universal), definindo a localização e a intensidade de cada sonda. Em seguida, os dados brutos foram submetidos ao programa de análise de dados de microarranjos disponível na página do Institute for Environmental Genomics (http://ieg.ou.edu/microarray/). Para tratamento dos dados foram empregados os seguintes passos: 1) sondas com intensidade de sinal inferior a 1.000 e com SNR (signal noise ratio - razão sinal: ruído) inferior a 2 foram eliminados, por serem considerados de baixa qualidade (SNR foi calculado como a intensidade de sinal do spot menos o background, dividido pelo desvio padrão do background); 2) o sinal de cada spot foi normalizado, dividindo seu valor pela média dos spots do padrão universal, e em seguida dividindo pela média de todas as sondas da amostra (HE et al., 2010; PAULA, 2012).

A intensidade de sinal normalizada de cada spot positivo foi considerada como a abundância de cada gene detectado. A comparação das abundâncias de genes entre as amostras foi possível devido à realização das seguintes etapas durante o experimento: 1) a mesma quantidade de DNA foi utilizada para todas as amostras; 2) a quantidade de corante incorporado foi equivalente para todas as amostras; 3) foi utilizada a mesma quantidade do padrão universal, o qual se liga a sondas específicas no microarranjo; 4) as etapas de normalização consideraram tanto o sinal do padrão universal, quanto a média obtida na amostra (PAULA, 2012).

As análises estatísticas foram realizadas na plataforma R 2.12.1 com os pacotes Stats e Vegan (R DEVELOPMENT CORE TEAM, 2010). Anova one-way, com posterior teste de Tukey, foram empregados para verificar diferenças na riqueza de genes entre os pontos de amostragem. Foi realizada a análise de agrupamento (cluster) para analisar como as amostras se agrupam, considerando a abundância de genes de cada processo funcional. Para isso, as sondas foram inicialmente agrupadas por processo funcional, somando as intensidades dos sinais, para obter a abundância total de genes de cada processo. Com os valores de abundância, foi construído um dendograma de cores, utilizando a função heatmap, onde a intensidade da cor é proporcional à abundância de genes. Os valores foram normalizados para cada processo funcional, com média zero e desvio padrão igual a um. Considerando os perfis de intensidades de cores apresentados por cada amostra, foi realizada a análise de agrupamento hierárquico pelo método de complete linkage, baseado na distância euclidiana 
entre as amostras. O programa R 2.12.1 também foi utilizado para construção do Diagrama de Venn e comparação entre as sondas de genes únicas e compartilhadas entre cada manguezal.

Os dados também foram ordenados por NMDS (Nonmetric Multidimensional Scaling), usando o índice de Bray-Curtis. NMDS emprega níveis de dissimilaridades entre as amostras para ordená-las no gráfico, de forma que as comunidades funcionais mais similares são plotadas mais próximas. Este método de ordenação foi escolhido, pois não pressupõe relação linear entre as variáveis, e é considerado um método robusto para avaliar dados ecológicos de comunidades (PAULA, 2012). 


\section{RESULTADOS E DISCUSSÃO}

\subsection{Análises físico-químicas e de hidrocarbonetos totais}

As amostras de sedimento de manguezais da cidade de Bertioga foram utilizadas neste trabalho por apresentarem diferentes históricos de exposição a HPAs e as amostras de Cananéia foram incluídas por apresentarem um modelo de manguezal não contaminado por HPAs de origem petrogênica.

Com a finalidade de caracterizar os sedimentos de cada ponto amostral dos manguezais foram realizadas análises de alguns parâmetros físico-químicos e os resultados estão discriminados na Tabela 1. É importante mencionar que os dados obtidos situam-se dentro da faixa de condições típicas de manguezais, especialmente no que diz respeito aos valores de pH que variaram de ácido a neutro $(5,9$ a 7,10) e porcentagem de matéria orgânica $(5,43$ a 12,89\%) estando de acordo com outros trabalhos encontrados na literatura (PAES, 2008; PRADA-GAMERO et al., 2004).

Ao analisar a Tabela 1, nota-se que as maiores variações intra-manguezal foram observadas para os pontos amostrais de Cananéia, principalmente com relação à granulometria (areia:silte:argila), salinidade, carbono e nitrogênio. No que diz respeito à granulometria, a relação areia:silte:argila apresentou o maior valor em CP2 $(1,14)$, que é um solo com o teor mais elevado de areia (82\%), e o menor valor foi obtido em CP1 $(0,02)$, que é um solo mais argiloso (52\%). Quanto às variações de salinidade, a maior porcentagem foi observada para CP1 (1,26\%) e a menor para CP3 (0,17\%). O ponto CP1 também apresentou maiores porcentagens de carbono (13,92\%) e nitrogênio $(0,72)$ que os pontos CP2 e CP3.

A Análise de Componentes Principais (PCA) foi realizada com as informações dos dados físico-químicos das amostras de sedimento para correlacionar as variáveis e os pontos amostrais, conforme representado na Figura 16. A PCA revelou três agrupamentos distintos considerando os ambientes estudados e a separação se fez por manguezal e não por tipo de ponto amostrado (curso d’água, floresta e restinga).

Observou-se na PCA que os manguezais de Bertioga (BA e BC) apresentaram características físico-químicas mais semelhantes entre si do que com Cananéia, sendo que os pontos BA1, BA2, BA3, BC1, BC2 e BC3 ficaram mais próximos entre si e relacionados a valores de $\mathrm{pH}$, matéria orgânica e umidade. 
Tabela 1. Análises físico-químicas dos pontos analisados dentro dos manguezais.

\begin{tabular}{lccc|ccc|ccc} 
& \multicolumn{3}{c}{$\begin{array}{c}\text { Bertioga } \\
\text { Antropizado }\end{array}$} & \multicolumn{3}{c|}{$\begin{array}{c}\text { Bertioga } \\
\text { Contaminado }\end{array}$} & \multicolumn{3}{c}{$\begin{array}{c}\text { Cananéia } \\
\text { Preservado }\end{array}$} \\
\hline \multicolumn{1}{c}{ Análises } & BA1 & BA2 & BA3 & BC1 & BC2 & BC3 & CP1 & CP2 & CP3 \\
\hline Areia (\%) & 71,00 & 59,00 & 57,00 & 34,00 & 69,00 & 35,00 & 22,00 & 82,00 & 78,00 \\
Silte (\%) & 24,00 & 36,00 & 38,00 & 60,00 & 26,00 & 50,00 & 26,00 & 6,00 & 12,00 \\
Argila (\%) & 5,00 & 5,00 & 5,00 & 6,00 & 5,00 & 15,00 & 52,00 & 12,00 & 10,00 \\
Areia:silte:argila & 0,59 & 0,33 & 0,30 & 0,94 & 0,53 & 0,47 & 0,02 & 1,14 & 0,65 \\
Condutividade (ms) & 5,56 & 8,22 & 8,36 & 7,77 & 8,01 & 8,84 & 20,81 & 11,42 & 3,54 \\
Salinidade (\%) & 0,30 & 0,46 & 0,46 & 0,47 & 0,46 & 0,48 & 1,26 & 0,68 & 0,17 \\
Umidade (\%) & 73,97 & 78,39 & 75,82 & 65,16 & 69,66 & 48,26 & 69,90 & 40,79 & 49,18 \\
Matéria Orgânica (\%) & 10,28 & 9,89 & 11,43 & 10,86 & 12,89 & 10,89 & 7,54 & 5,43 & 6,35 \\
Carbono Orgânico (\%) & 4,77 & 4,62 & 5,19 & 5,33 & 5,60 & 5,15 & 12,23 & 3,04 & 3,53 \\
Carbono (\%) & 5,71 & 5,50 & 6,35 & 6,03 & 7,16 & 6,05 & 13,92 & 5,10 & 6,95 \\
pH & 7,10 & 6,80 & 6,90 & 6,90 & 6,80 & 6,40 & 5,90 & 6,40 & 6,30 \\
Nitrogênio (\%) & 0,29 & 0,26 & 0,34 & 0,13 & 0,45 & 0,31 & 0,72 & 0,21 & 0,23 \\
Fósforo (\%) & 0,07 & 0,07 & 0,12 & 0,13 & 0,11 & 0,19 & 0,07 & 0,11 & 0,09 \\
Potássio (\%) & 0,08 & 0,07 & 0,08 & 0,09 & 0,08 & 0,20 & 0,14 & 0,08 & 0,04 \\
Cálcio (\%) & 0,24 & 0,19 & 0,23 & 0,27 & 0,31 & 0,33 & 0,15 & 0,22 & 0,19 \\
Magnésio (\%) & 0,19 & 0,17 & 0,19 & 0,20 & 0,23 & 0,34 & 0,19 & 0,10 & 0,07 \\
Enxofre (\%) & 0,24 & 0,26 & 0,20 & 0,31 & 0,36 & 0,32 & 0,23 & 0,14 & 0,14 \\
Sódio (mg/kg) & 4,77 & 4,40 & 4,95 & 5,33 & 8,09 & 9,50 & 7,35 & 2,24 & 1,34 \\
\hline
\end{tabular}

Fonte: Dias et al. (2011)

Figura 16. Análise de Componentes Principais baseada nas características físico-químicas dos sedimentos de manguezais analisados.

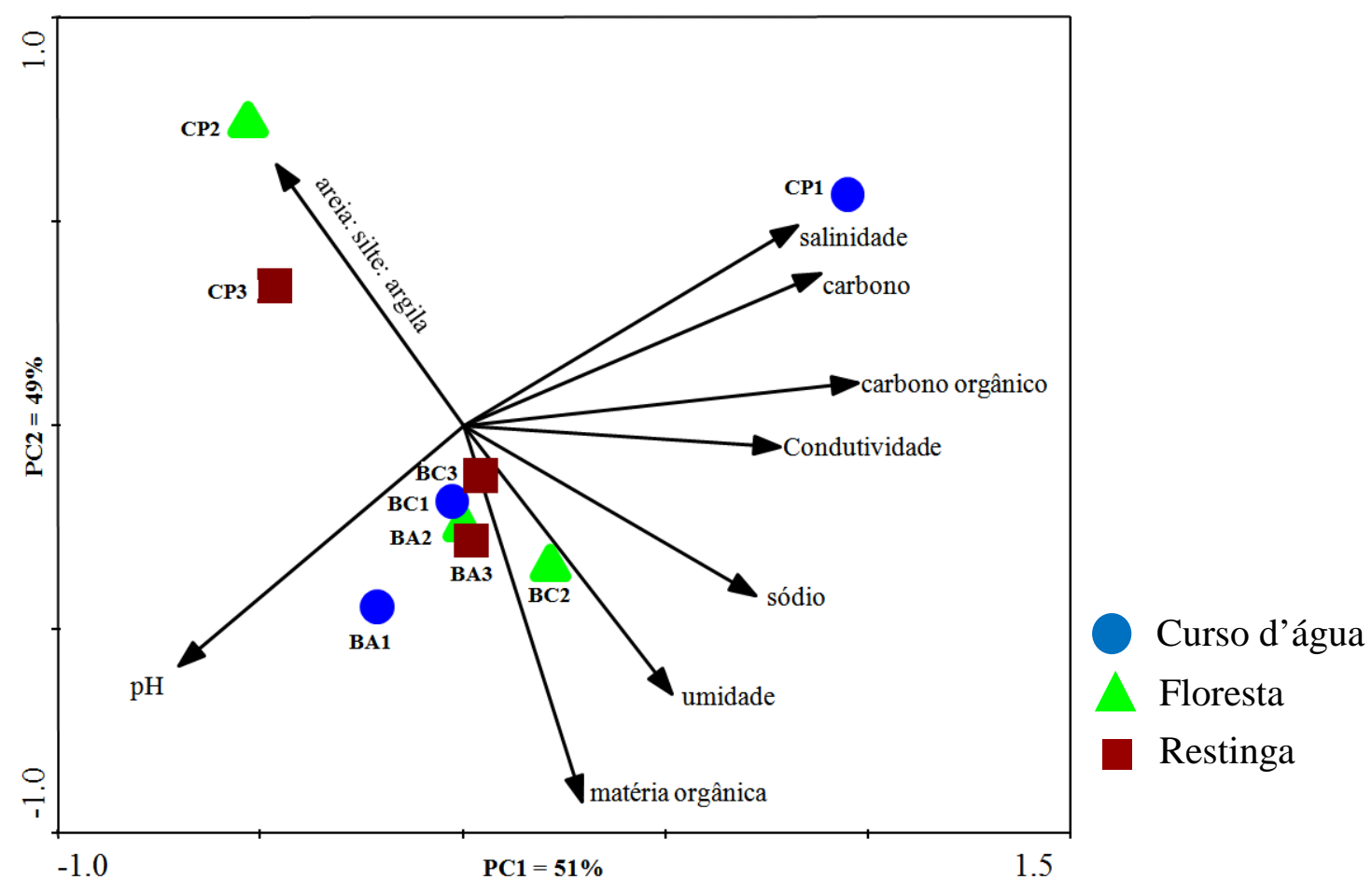


As amostras CP2 e CP3 apresentaram maior correlação com a granulometria do sedimento e a PCA também evidenciou uma relação inversa entre os valores de umidade e matéria orgânica para o ponto CP2. Já o ponto CP1 apresentou-se como um ponto totalmente distanciado dos demais, associando-se a valores de salinidade e carbono. Um fator importante a se considerar no que diz respeito às diferenças observadas no ponto CP1 é que no manguezal de Cananéia, especialmente em CP1 a inundação da maré é feita exclusivamente por água do oceano atlântico, enquanto que nos manguezais de Bertioga esse aporte é uma mistura de água doce (Rio Iriri) e água do mar (DIAS et al., 2011).

As amostras de sedimento também foram avaliadas quanto à presença de 39 Hidrocarbonetos Policíclicos Aromáticos para verificar se ainda existem remanescentes de HPAs no manguezal que sofreu derramamento de petróleo há 29 anos. A Tabela 2 apresenta as concentrações individuais dos HPAs analisados. Nesta tabela observa-se que a medida de hidrocarbonetos policíclicos aromáticos totais ( $\Sigma$-HPAs) variou em peso seco de 60,71 a 827,7 ng.g $\mathrm{g}^{-1}$ e os pontos amostrais que apresentaram as maiores concentrações foram os de

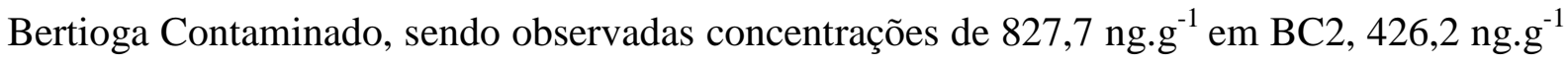
em BC3 e 316,1 ng.g - $^{-1}$ em BC1.

No Brasil não existe uma legislação que assegure a qualidade ambiental dos sedimentos costeiros com relação à presença de HPAs e seus limites de detecção, o que faz com que os autores usem os limites padronizados e estabelecidos por outras Agências Regulatórias Internacionais como a NOAA - National Oceanic and Atmospheric Administration (USA) e o Environment Canada que utilizam 16 compostos de HPAs como referência. Além destas agências, tem-se o ANZECC/ARMCANZ - Australian and New Zealand Environment Conservation Council/Agriculture and Resource Management Council of Australia and New Zealand (SANTOS et al., 2011a).

Apesar das diferenças de concentração de HPAs observadas entre os manguezais de Bertioga e Cananéia, nenhuma de nossas amostras apresentou concentração de HPAs superior aos valores máximos estabelecidos pelas agências reguladoras internacionais. Segundo a ANZECC/ARMCANZ (2000) os HPAs que merecem atenção quanto à contaminação dos sedimentos são: acenafteno, acenaftileno, fluoreno, naftaleno, fenantreno, criseno, fluoranteno, pireno, benzo(a)antraceno, benzo(a)pireno, dibenzo(a,h)antraceno e bifenilo. 
Tabela 2. Concentração de Hidrocarbonetos Policíclicos Aromáticos (ng.g ${ }^{-1}$ peso seco) nas amostras de sedimento dos manguezais analisados.

\begin{tabular}{|c|c|c|c|c|c|c|c|c|c|}
\hline \multirow[b]{2}{*}{ Hidrocarbonetos } & \multicolumn{3}{|c|}{ Bertioga Antropizado } & \multicolumn{3}{|c|}{ Bertioga Contaminado } & \multicolumn{3}{|c|}{ Cananéia Preservado } \\
\hline & BA1 & BA2 & BA3 & BC1 & BC2 & BC3 & CP1 & CP2 & CP3 \\
\hline 1-Naftaleno & 13,27 & 1,60 & 1,60 & 4,70 & 2,82 & 1,80 & 1,60 & 1,60 & 1,60 \\
\hline 2-Metilnaftalenos & 20,47 & 1,52 & 1,30 & 1,30 & 2,49 & 1,34 & 1,30 & 1,30 & 1,30 \\
\hline 3-Bifenilo & 2,49 & 1,30 & 1,30 & 1,30 & 1,30 & 1,30 & 1,30 & 1,30 & 1,30 \\
\hline 4-Etilnaftalenos & 2,60 & 2,60 & 2,60 & 2,60 & 2,60 & 2,60 & 2,60 & 2,60 & 2,60 \\
\hline 5-Dimetilnaftalenos & 11,13 & 5,21 & 2,60 & 2,60 & 11,73 & 4,79 & 2,60 & 2,60 & 2,60 \\
\hline 6-Acenaftileno & 3,70 & 3,70 & 3,70 & 3,70 & 3,70 & 3,70 & 3,70 & 3,70 & 3,70 \\
\hline 7-Acenafteno & 1,30 & 1,30 & 1,30 & 1,30 & 1,30 & 1,30 & 1,30 & 1,30 & 1,30 \\
\hline 8-Trimetilnaftalenos & 2,89 & 1,64 & 1,30 & 2,53 & 4,45 & 3,07 & 1,44 & 1,30 & 1,30 \\
\hline 9-Fluoreno & 1,30 & 1,30 & 1,30 & 1,30 & 1,90 & 1,30 & 1,30 & 1,30 & 1,30 \\
\hline 10-Metilfluorenos & 1,30 & 1,73 & 1,30 & 1,76 & 6,82 & 3,27 & 1,30 & 1,30 & 1,30 \\
\hline 11-Dibenzotiofeno & 1,30 & 1,30 & 1,30 & 1,30 & 1,85 & 1,30 & 1,30 & 1,30 & 1,30 \\
\hline 12-Fenantreno & 3,50 & 2,60 & 2,60 & 2,60 & 3,42 & 2,60 & 2,60 & 2,60 & 2,60 \\
\hline 13-Antraceno & 1,10 & 1,20 & 1,10 & 1,10 & 2,02 & 1,10 & 1,10 & 1,10 & 1,10 \\
\hline 14-Dimetilfluorenos & 1,30 & 1,30 & 1,30 & 1,30 & 6,86 & 4,66 & 1,30 & 1,30 & 1,30 \\
\hline 15-Metildibenzotiofenos & 1,30 & 1,30 & 1,30 & 1,30 & 1,30 & 1,30 & 1,30 & 1,30 & 1,30 \\
\hline 16-Metilfenantrenos & 3,05 & 4,03 & 2,20 & 2,49 & 8,53 & 2,92 & 2,20 & 2,20 & 2,20 \\
\hline 17-Dimetildibenzotiofenos & 1,30 & 1,30 & 1,30 & 1,30 & 1,30 & 2,45 & 1,30 & 1,30 & 1,30 \\
\hline 18-Dimetilfenantrenos & 2,96 & 2,49 & 2,20 & 3,46 & 11,92 & 9,43 & 2,20 & 2,20 & 2,20 \\
\hline 19-Fluoranteno & 10,82 & 9,73 & 5,17 & 8,68 & 10,82 & 6,37 & 2,04 & 1,30 & 1,30 \\
\hline 20-Pireno & 8,19 & 7,09 & 3,84 & 7,27 & 14,49 & 7,12 & 1,44 & 1,20 & 1,20 \\
\hline 21-Metilfluorantenos & 3,84 & 3,12 & 1,73 & 3,82 & 61,90 & 7,00 & 1,30 & 1,30 & 1,30 \\
\hline 22-Reteno & 1,30 & 1,30 & 1,30 & 1,30 & 1,97 & 1,46 & 1,30 & 1,30 & 1,30 \\
\hline 23-Metilpireno & 3,00 & 2,48 & 1,30 & 3,92 & 56,87 & 15,80 & 1,30 & 1,30 & 1,30 \\
\hline 24-Benzo(c)fenantreno & 1,34 & 1,20 & 1,20 & 1,20 & 1,20 & 1,20 & 1,20 & 1,20 & 1,20 \\
\hline 25-Benzo(a)antraceno & 6,50 & 4,14 & 2,55 & 4,89 & 4,65 & 5,47 & 1,93 & 1,30 & 1,35 \\
\hline 26-Criseno & 6,69 & 4,05 & 3,47 & 5,07 & 68,47 & 30,34 & 1,22 & 1,20 & 1,20 \\
\hline 27-Metilcrisenos & 7,65 & 8,38 & 3,01 & 8,78 & 172,39 & 66,05 & 1,36 & 1,20 & 1,20 \\
\hline 28-Dimetilcrisenos & 3,28 & 2,73 & 1,96 & 7,96 & 203,16 & 88,01 & 1,20 & 1,20 & 1,20 \\
\hline 29-Benzo(b)fluoranteno & 7,37 & 5,27 & 3,42 & 5,38 & 10,29 & 5,62 & 1,47 & 1,30 & 1,30 \\
\hline 30-Benzo(j)fluoranteno & 4,31 & 2,73 & 1,93 & 4,11 & 8,43 & 5,28 & 1,30 & 1,30 & 1,30 \\
\hline 31-Benzo(k)fluoranteno & 5,21 & 3,22 & 2,29 & 5,10 & 6,79 & 5,30 & 1,30 & 1,30 & 1,30 \\
\hline 32-Benzo(e)pireno & 7,50 & 5,98 & 3,35 & 6,02 & 55,01 & 15,02 & 1,30 & 1,30 & 1,30 \\
\hline 33-Benzo(a)pireno & 6,90 & 4,23 & 3,34 & 4,72 & 5,68 & 3,77 & 1,20 & 1,10 & 1,10 \\
\hline 34-Perileno & 26,00 & 22,87 & 22,79 & 110,36 & 22,40 & 52,75 & 72,55 & 4,26 & 53,24 \\
\hline 35-Indeno[1,2,3-c,d]pireno & 17,36 & 10,03 & 11,43 & 38,89 & 12,48 & 18,12 & 17,99 & 1,15 & 1,00 \\
\hline 36-Dibenzo(a,h)antraceno & 3,98 & 2,18 & 2,18 & 7,65 & 11,57 & 10,57 & 1,14 & 1,00 & 1,00 \\
\hline 37-Benzo(b)criseno & 2,12 & 1,10 & 1,14 & 4,29 & 1,37 & 1,29 & 1,10 & 1,10 & 1,10 \\
\hline 38-Benzo(g,h,i)perileno & 19,95 & 9,11 & 10,26 & 27,85 & 17,99 & 21,93 & 14,55 & 1,60 & 1,20 \\
\hline 39-Coroneno & 6,52 & 4,04 & 5,64 & 10,89 & 3,46 & 7,53 & 6,64 & 1,20 & 1,20 \\
\hline$\Sigma$-HPAs & 236,09 & 152,40 & 124,90 & 316,09 & 827,70 & 426,23 & 166,57 & 60,71 & 109,19 \\
\hline Fluoranteno/Pireno & 1,32 & 1,37 & 1,35 & 1,19 & 0,75 & 0,89 & 1,42 & 1,08 & 1,08 \\
\hline Benzo(a)antraceno/criseno & 0,97 & 1,02 & 0,73 & 0,96 & 0,07 & 0,18 & 1,58 & 1,08 & 1,12 \\
\hline
\end{tabular}


Os HPAs que apresentaram as maiores concentrações individuais em BC2 são de alto peso molecular (com 4 aromáticos): dimetilcriseno (203,16 ng.g ${ }^{-1}$ ) e metilcriseno (172,39 ng. $\left.\mathrm{g}^{-1}\right)$, seguidos de metilfluoranteno (61,90 ng.g $\mathrm{g}^{-1}$ ) e metilpireno (56,87 ng.g $\left.\mathrm{g}^{-1}\right)$. Em BC3 as maiores concentrações foram observadas para HPAs de 4 e 5 anéis aromáticos, respectivamente, sendo eles: o dimetilcriseno (88,01 ng.g $\mathrm{g}^{-1}$ ) e pirileno (52,75 ng.g $\left.{ }^{-1}\right)$. Já em BC1 as maiores concentrações de HPAs foram observadas para compostos de 5 anéis aromáticos: pirileno (110,36 ng.g $\left.{ }^{-1}\right)$ e o indeno[1,2,3-c,d]pireno (38,89 ng.g $\left.{ }^{-1}\right)$.

A literatura mostra que as concentrações de HPAs totais encontradas em diferentes sedimentos variam amplamente. Valores abaixo dos encontrados em nosso estudo foram obtidos por Yang et al. (2000) que avaliaram 16 amostras de sedimento coletadas em diferentes regiões costeiras da China e verificaram valores de concentração total de HPAs

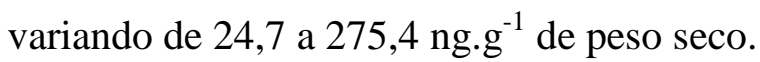

Valores próximos aos encontrados em nosso estudo foram verificados por Zhang et al. (2004) que também trabalharam com amostras de sedimento para verificar as concentrações de HPAs de 20 amostras coletadas de três transectos de um manguezal em Shenzhen na China. As concentrações totais variaram de 237 a 726 ng.g ${ }^{-1}$ de peso seco.

Valores superiores foram encontrados por Tam et al. (2001), que analisaram 20 amostras superficiais de sedimento de quatro manguezais localizados em Hong Kong (Sai Keng, Tolo, Ho Chung e Mai Po) e seus resultados indicaram contrações totais de HPAs variando de 356 a 11.098 ng.g g $^{-1}$ de peso seco. Estes autores verificaram que os manguezais que se localizavam mais próximos às cidades e aos esgotos industriais foram aqueles que apresentaram as maiores concentrações de HPAs.

Vale ressaltar que os compostos aromáticos investigados que mais se pronunciam em presença de fonte predominantemente petrogênica são: naftalenos, fluorenos, benzotiofenos e dibenzotiofenos, antraceno e fenantrenos, todos com seus respectivos homólogos alquilados (COIMBRA, 2006). Já os compostos bifenilo e dibenzofurano policlorados são caracterizados como poluentes orgânicos persistentes e sua detecção em solos e sedimentos remete à contaminação por lixo industrial, incineração de madeira e/ou dejetos e derramamento de óleo (CHENG \& HU, 2010; SHELEPCHIKOV et al., 2011; WU, Y.-L. et al., 2009).

Em nosso trabalho a Análise de Componentes Principais (PCA) também foi realizada com as informações de concentração dos HPAs para correlacionar as variáveis e os pontos amostrais, conforme representado na Figura 17. A PCA revelou que os pontos amostrais de Cananéia não apresentaram correlação com nenhum dos HPAs analisados, mas em contrapartida os pontos BA1 e BC1 mostraram-se correlacionados ao bifenilo e 
benzo(b)criseno e os pontos BC2 e BC3 apresentaram-se associados a dimetildibenzotiofeno, antraceno, metilfluoreno, dimetilfluoreno (indicadores de origem petrogênica) e dimetilfenantreno.

Figura 17. Análise de Componentes Principais baseada nas concentrações de HPAs dos sedimentos dos manguezais analisados.

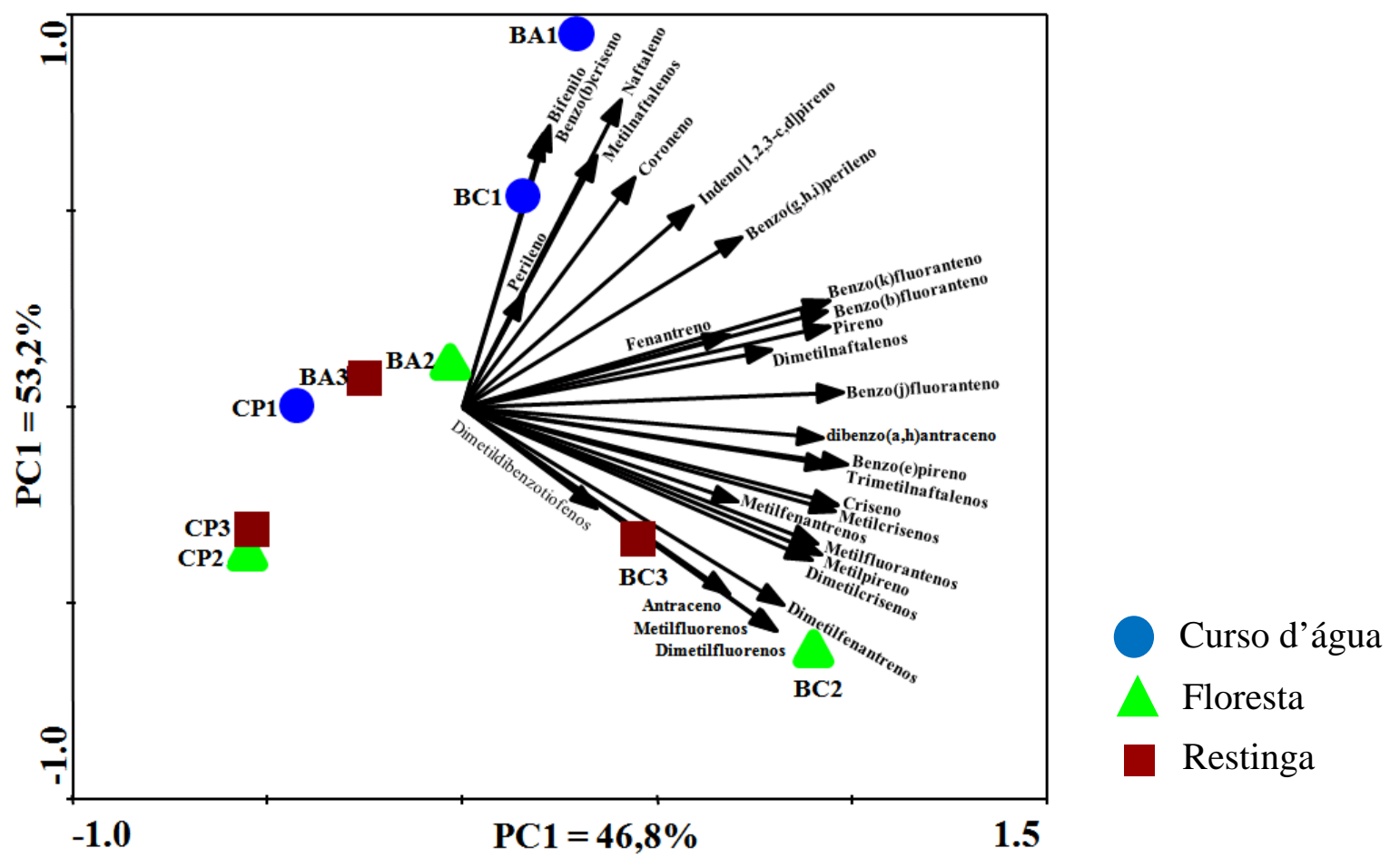

Muitos trabalhos utilizam a relação fenantreno/antraceno e fluaranteno/pireno como um indicador para determinar a origem dominante dos HPAs (TAM et al., 2001). Razões de fenantreno/antraceno inferiores a 10 indicam que a maior introdução de HPAs no sistema foi pirogênica, enquanto aquelas razões superiores a 10 indicam uma origem petrogênica. Uma outra forma de análise é a razão fluoranteno/pireno, que quando inferior a 1,0 indica fonte petrogênica e superior a 1,0 é relacionada a origem pirogênica (SOCLO et al., 2000). Também é importante considerar a razão benzo(a)antraceno/criseno e os valores relacionados a origem petrogênica são < 0,40 (TAM et al., 2001).

Em nosso estudo a razão fenantreno/antraceno não foi superior a 10 em nenhuma das amostras, mas em contrapartida as razões fluoranteno/pireno e benzo(a)antraceno/criseno demonstraram que nos pontos BC2 $(0,75$ e 0,02$)$ e BC3 $(0,89$ e 0,18$)$ a origem dos HPA é petrogênica, como pode ser observado na Figura 18. 
Figura 18. Razão fluoranteno/pireno x Razão benzo(a)antraceno/criseno observada nos sedimentos dos manguezais analisados.

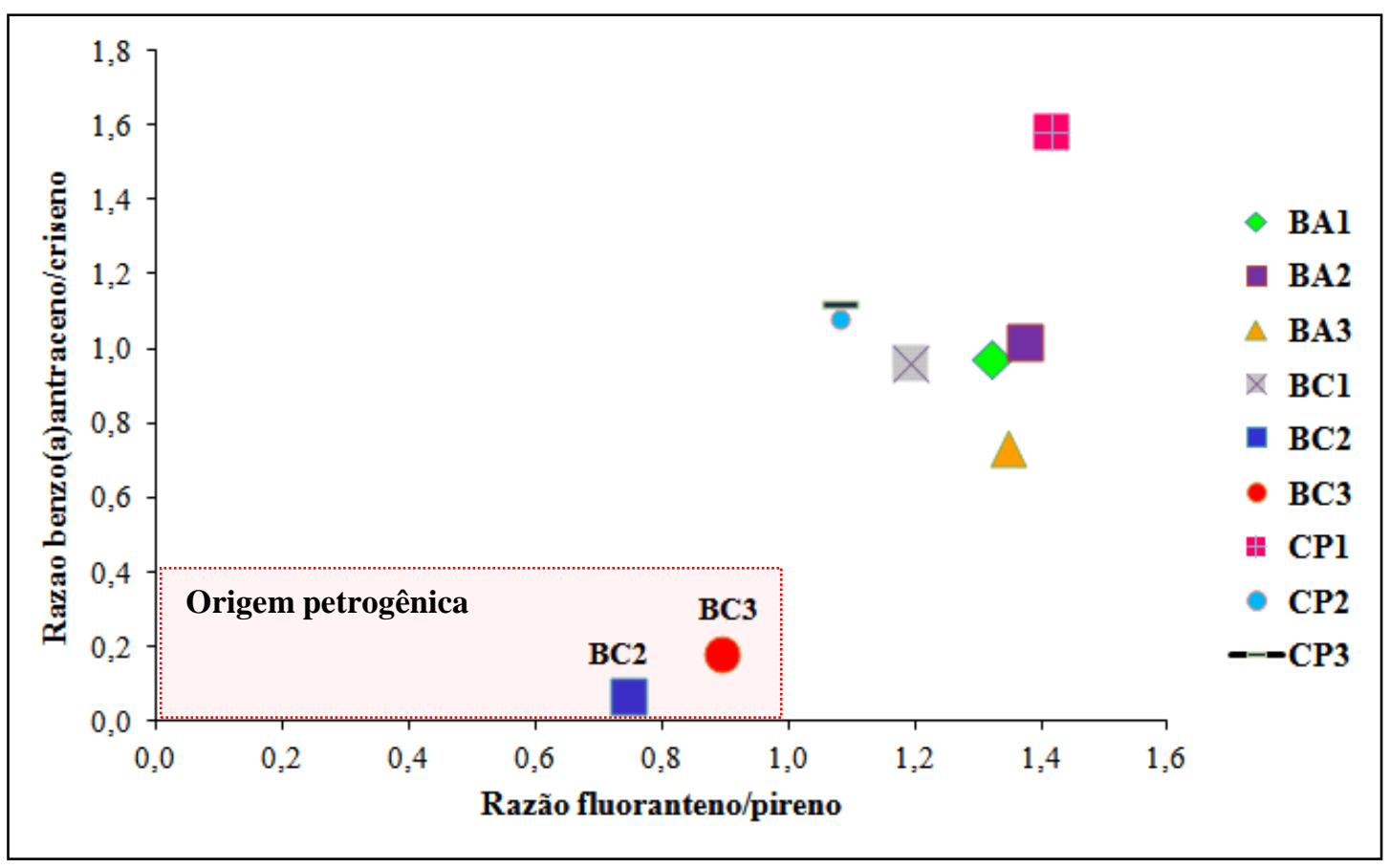

O ambiente de Bertioga (BC) tem sido monitorado desde a época do acidente de derramamento e a medida de HPAs se tornou objeto importante de nexo causal na batalha jurídica para coprovação do dano ambiental ali causado. A análise de concentração de HPAs do óleo da época do derramamento demonstrou uma concentração total de 46.896 ng.g ${ }^{-1}$ e a concentração de bifenilo foi de 596,79 ng.g ${ }^{-1}$. A Tabela 3 mostra os resultados obtidos por Coinbra (2006) nos anos de 2.001 e 2.005 e os resultados encontrados por nosso grupo de pesquisa em 2.009 .

Tabela 3. Acompanhamento das concentrações totais de HPAs ( $\Sigma$ - HPAs) e do bifenilo no óleo do derramamento e nas amostras de Bertioga (BC) nos anos de 2001, 2005 e 2009.

\begin{tabular}{lcccc|ccc|ccc}
\hline \multirow{2}{*}{ Composto } & \multirow{2}{*}{ Óleo } & \multicolumn{3}{c|}{ BC1 } & \multicolumn{3}{c|}{ BC2 } & \multicolumn{3}{c}{ BC3 } \\
\cline { 3 - 10 } & & $\mathbf{2 0 0 1}$ & $\mathbf{2 0 0 5}$ & $\mathbf{2 0 0 9}$ & $\mathbf{2 0 0 1}$ & $\mathbf{2 0 0 5}$ & $\mathbf{2 0 0 9}$ & $\mathbf{2 0 0 1}$ & $\mathbf{2 0 0 5}$ & $\mathbf{2 0 0 9}$ \\
\hline Bifenilo & 596,8 & 2,0 & 1,5 & 1,3 & 2,8 & 2,3 & 1,3 & 4,0 & 1,3 & 1,3 \\
$\Sigma$ - HPAs & 46.896 & 538,2 & 366,7 & 316,1 & 740,1 & 991,1 & 827,7 & 1.239 & 538,3 & 426,2 \\
\hline
\end{tabular}

*Concentrações mensuradas em ng.g ${ }^{-1}$ de peso seco 
Por comparação com os resultados obtidos por Coinbra (2006), observa-se que as concentrações totais de HPAs ( $\Sigma$ - HPAs) e de bifenilo têm diminuído ao longo dos anos. Vale ressaltar que em 2.001 na amostra BC2 a medida de concentração total de HPAs não foi realizada para alguns compostos (antraceno, benzo(b)fluoranteno, benzo(k)fluoranteno, benzo(e)pireno e pirileno), motivo pelo qual a $\Sigma$ - HPAs foi menor que a $\Sigma$ - HPAs de 2.005 e 2.009. Uma informação importante é que nas medidas de 2001 e 2005 houve comprovação de origem petrogênica dos HPAs para todos os pontos amostrais de Bertioga (BC), mas nas medidas que realizamos em 2009 a amostra BC1 já não mais apresenta indicação de origem petrogênica. Trata-se do ponto amostral mais distante do local onde houve o derramamento, que possui contato direto com o curso d'água e aquele que sempre apresentou as menores concentrações de HPAs desde as primeiras análises.

O fato de se constatar a presença de HPAs de origem petrogênica nos pontos BC2 e BC3, mesmo após 29 anos transcorridos desde o derramamento, é um importante indicador dos efeitos crônicos da contaminação causada pelo petróleo, muitas vezes de difícil diagnóstico após um longo período. A redução da concentração desses HPAs ao longo destes anos também é um indicador da presença de micro-organismos com capacidade para degradação desses compostos no ambiente de manguezal. 


\subsection{Análise do gene $\alpha$-ARHD}

Todas as amostras utilizadas neste estudo amplificaram o fragmento esperado de 300$329 \mathrm{pb}$ do gene $\alpha$-ARHD, demonstrando a presença de micro-organismos produtores de enzimas envolvidas na degradação de hidrocarbonetos aromáticos em todos os manguezais estudados. Obtivemos um total de 1119 clones que apresentaram alinhamentos significativos com a subunidade alfa de dioxigenases aromáticas depositadas no GenBank.

Destas seqüências 389 (34,8\%) foram obtidas a partir das amostras do manguezal de Bertioga Antropizado (BA), 386 (34,5\%) a partir de Bertioga Contaminado (BC) e 344 (30,7\%) a partir das amostras de Cananéia (CP). Verificou-se uma considerável diversidade de genes $\alpha$-ARHD nos manguezais amostrados e as seqüências foram relacionadas com enzimas associadas à degradação dos substratos bifenilo (55,0\%), naftaleno (21,9\%), dibenzofurano (16,9\%), benzeno (3,2\%) e 3-fenilpropanoato (3,0\%).

As enzimas $\alpha$-ARHD encontradas neste estudo mostraram-se associadas, pela utilização da ferramenta TBlastx (NCBI), às seguintes seqüências depositadas no banco de dados: clones ambientais (92,5\%), Janibacter sp. (7,2\%) e Pseudomonas putida (0,3\%) para bifenilo dioxigenase; Burkholderia phenazinium (44,9\%), Pseudomonas stutzeri (32,3\%), Comamonas testosteroni (22,0\%), Pseudomonas fluorescens (0,1\%) e Herbaspirilum sp. (0,1\%) para naftaleno dioxigenases; Nocardioides sp. (87,3\%) e Rhodococcus sp. (12,7\%) para dibenzofurano dioxigenases; Shigella flexneri (66,7\%) e Rhodococcus opacus $(33,3 \%)$ para benzeno dioxigenases; e Sphingobium chlorophenolicum (100\%) para a 3-fenilpropanoato dioxigenase. A Figura 19 mostra as diferenças de diversidade entre as bibliotecas analisadas. Fica evidente nos gráficos a maior variedade de dioxigenases no ponto BC3 da região de Bertioga Contaminado, exatamente onde houve o derramamento de petróleo no ano de 1.983. A maior heterogeneidade de grupos de dioxigenases nesse ponto pode ser resultado da variedade de substratos que ali foram inseridos, demonstrando a resposta da população microbiana ao estresse sofrido.

Apesar de uma grande parte das seqüências proteicas de bifenilo dioxigenase analisadas neste estudo apresentarem similaridade somente com clones ambientais, para as demais enzimas foi possível observar a presença de gêneros bacterianos estreitamente relacionados a processos de biodegradação de HPAs como Pseudomonas, Burkholderia e Rhodococcus (KITAGAWA et al., 2001; MA et al., 2006b; TILLMANN et al., 2005). Alguns estudos têm descrito os micro-organismos Mycobacterium spp., Sphingomonas spp., Rhodococcus spp., 
Arthrobacter spp., e Nocardia spp. como seletivamente estimulados em solos contaminados por hidrocarbonetos (DAANE et al., 2001; KANALY et al., 2000a).

Em estudos conduzidos em áreas de manguezais os autores verificam que diferentes perfis de populações microbianas podem indicar o impacto por diferentes contaminantes derivados de petróleo e os micro-organismos podem ser usados como indicadores de qualidade dos solos nesses ecossistemas (PEIXOTO et al., 2011; TAM et al., 2002; ZHOU et al., 2009).

Figura 19. Classificação das bibliotecas do gene $\alpha$-ARHD pela utilização da ferramenta Tblastx a partir das amostras analisadas.

A

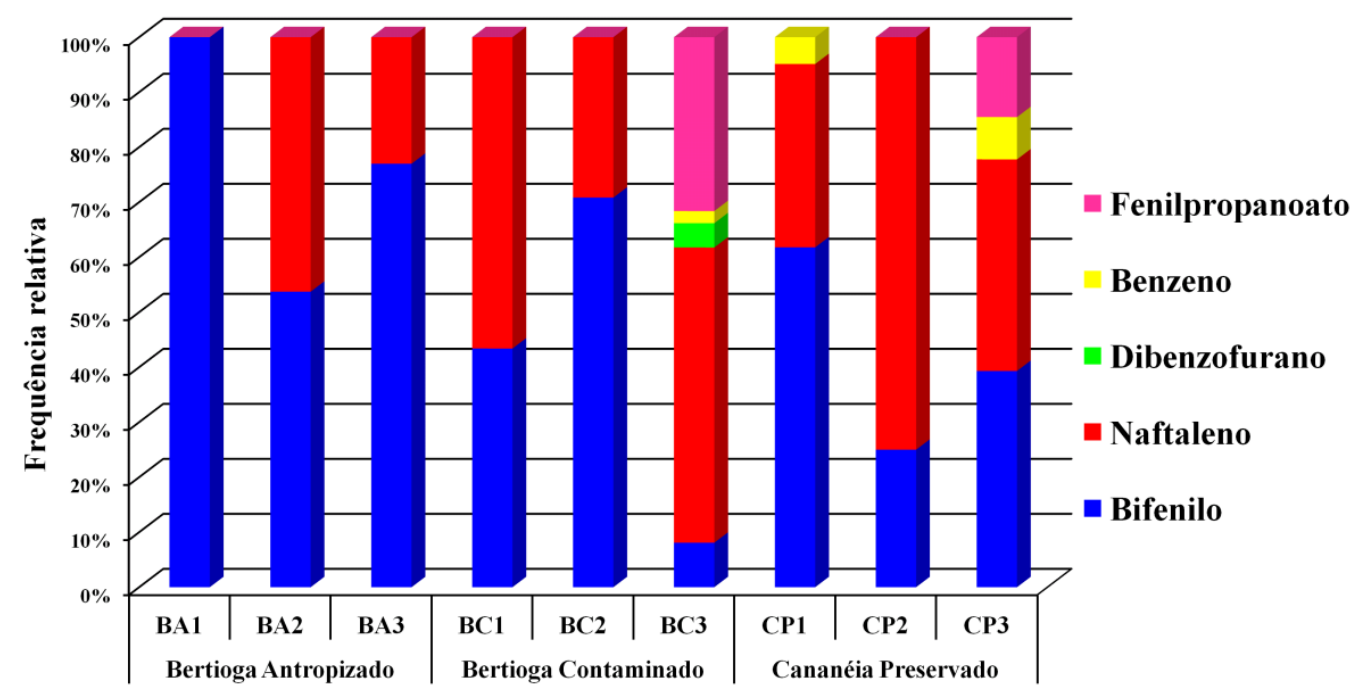

B

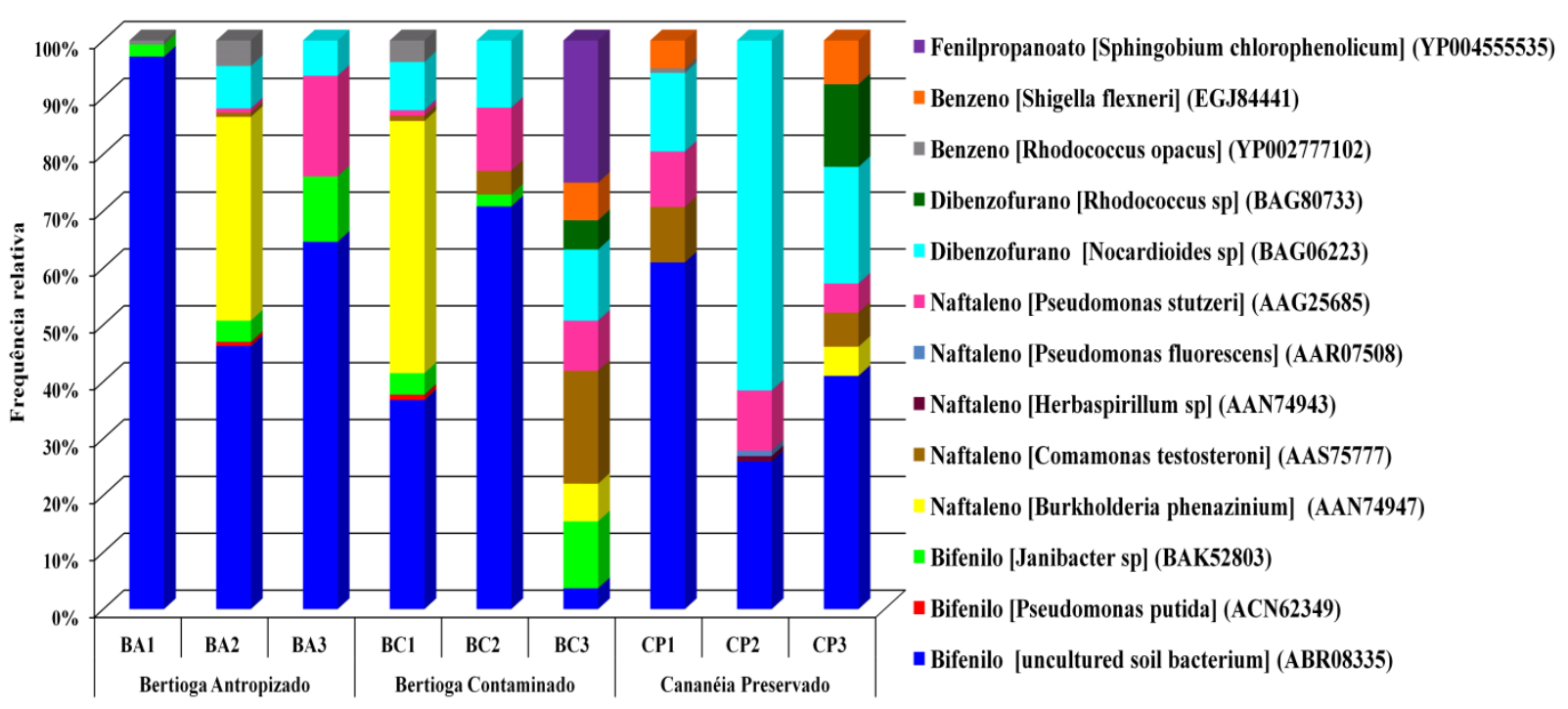

A - enzimas detectadas em cada ponto amostral; B - micro-organismos hospedeiros das enzimas. 
Os HPAs têm sido reportados por causar redução/alteração na diversidade microbiana nos mais variados ambientes (JUCK et al., 2000; ROLING et al., 2002). Em muitos casos a seleção e o aumento de uma comunidade microbiana específica também ocorrem. Em ecossistemas não poluídos os micro-organismos degradadores de HPAs usualmente representam menos que $0,1 \%$ dos heterotróficos cultiváveis, enquanto em ambientes contaminados eles constituem quase que $100 \%$ da população viável (ANDREONI \& GIANFREDA, 2007; ZHOU et al., 2009).

Utilizando amostras urbanas de manguezais da Baía da Guanabara Gomes e colaboradores (2008) verificaram que cada manguezal apresentava uma estrutura específica de comunidade bacteriana e as bandas de DGGE revelaram ribotipos relacionados a Alteromonadales, Burkholderiales, Pseudomonadales, Rhodobacterales e Rhodocydales.

As relações filogenéticas entre as seqüências de dioxigenases identificadas neste estudo, e destas com seqüências referência selecionadas a partir do banco de dados (Genbank) estão mostradas nas Figuras 20, 21 e 22. De forma geral, as sequências obtidas em nosso estudo apresentaram valores de similaridade variando de 54 a 97\% com as sequências depositadas no Genbank.

Com relação às famílias de dioxigenases, tivemos representantes dos grupos IV bifenilo e benzeno dioxigenases, III - naftaleno dioxigenases, e enzimas 3-Fenilpropanoato e Dibenzofurano dioxigenases, que apresentam maior similaridade com a família bifenilo dioxigenase, mas para as quais ainda não foram descritas famílias de $\alpha$-ARHDS. Enzimas associadas à degradação de fenilpropanoato só foram detectadas nas amostras do ponto BC3 de Bertioga.

Em um estudo conduzido por Belicanta (2004) em que foram utilizadas amostras de sedimento de áreas estuarinas em Cubatão (próximo à COSIPA - Companhia Siderúrgica Paulista) e São Vicente, também foram encontradas enzimas dioxigenases relacionadas à degradação de bifenilo, benzeno, naftaleno e dibenzofurano, como aquelas encontradas em nosso estudo. Além destas, o referido autor também encontrou, na biblioteca das amostras de sedimentos de Cubatão, enzimas relacionadas à degradação de clorobenzeno e dibenzotiofeno. Semelhante aos nossos resultados, os micro-organismos associados a essas enzimas foram relacionados aos gêneros Pseudomonas, Rhodococcus, Comamonas e Ralstonia. 
Figura 20. Árvore de similaridade construída a partir do alinhamento das seqüências representativas dos clones do manguezal de Bertioga Antropizado e as seqüências de referência das enzimas ARHD.

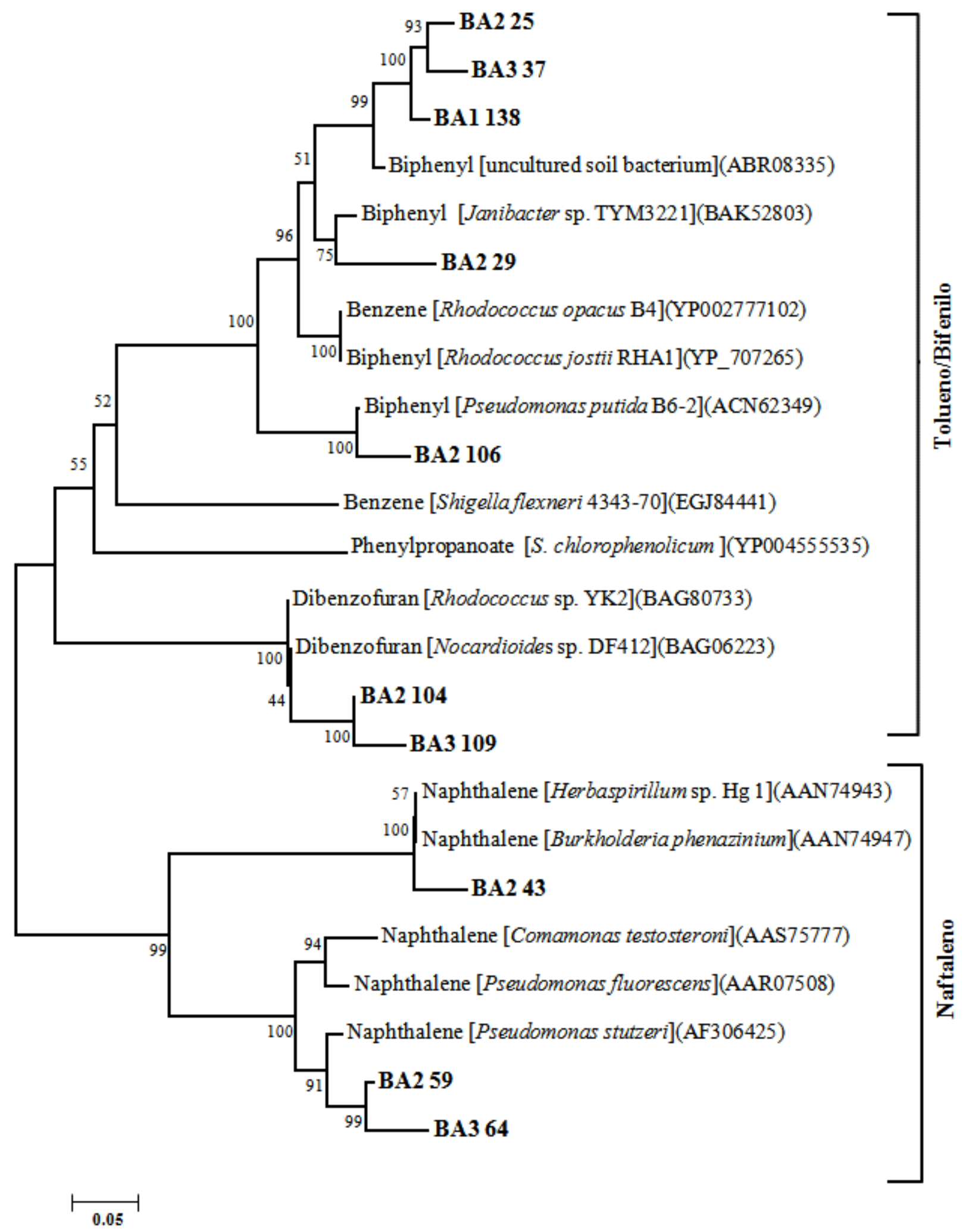

Árvore gerada com o método de Neighbor-Joining, pelo modelo de substituição de resíduos de aminoácidos por Matriz PAM (Dayhoff) e valor de bootstrap de 1.000 repetições. A escala indica a porcentagem de divergência entre as seqüências. 
Figura 21. Árvore de similaridade construída a partir do alinhamento das seqüências representativas dos clones do manguezal de Bertioga Contaminado e as seqüências de referência das enzimas ARHD.

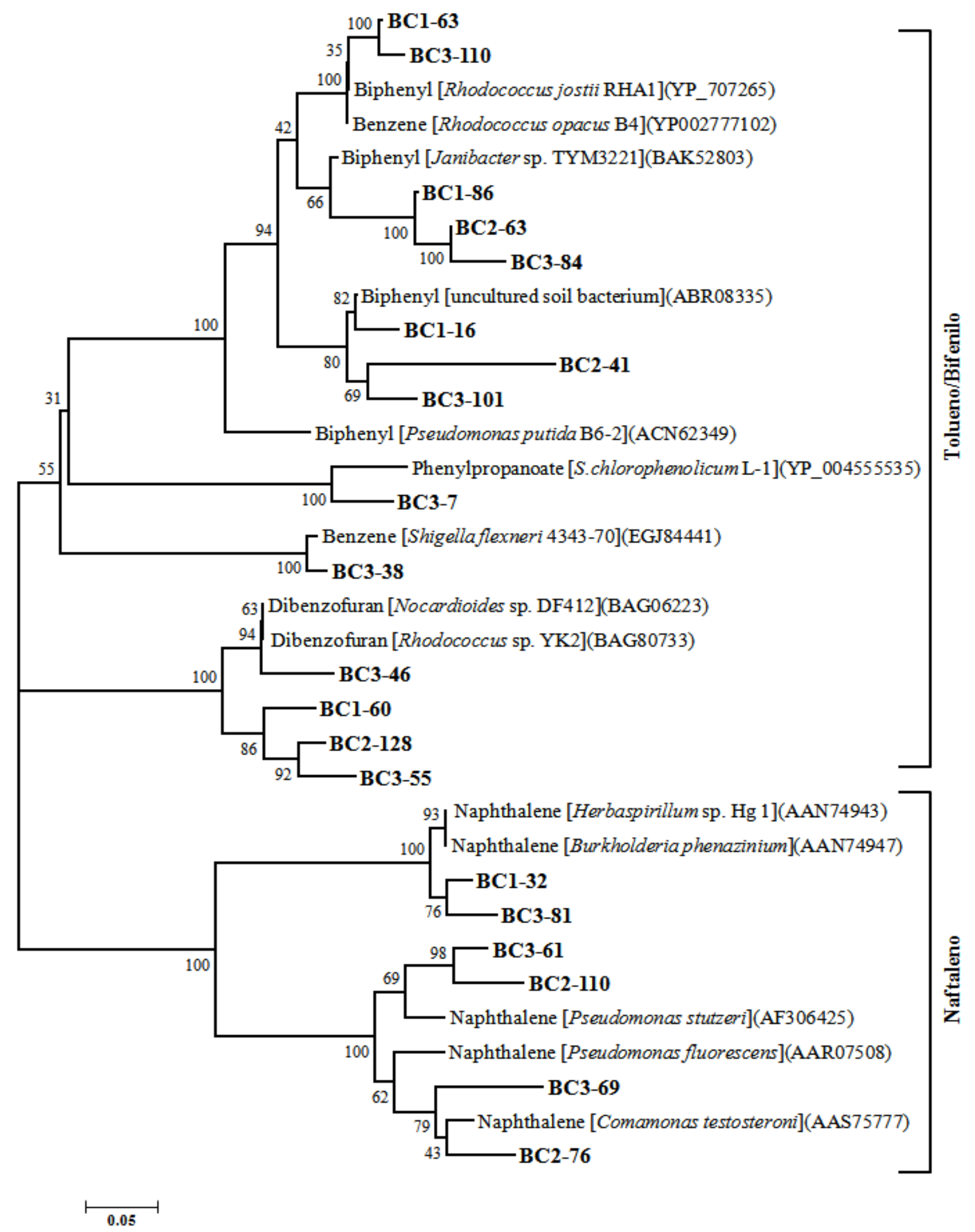

Árvore gerada com o método de Neighbor-Joining, pelo modelo de substituição de resíduos de aminoácidos por Matriz PAM (Dayhoff) e valor de bootstrap de 1.000 repetições. A escala indica a porcentagem de divergência entre as seqüências. 
Figura 22. Árvore de similaridade construída a partir do alinhamento das seqüências representativas dos clones do manguezal de Cananéia Preservado e as seqüências de referência das enzimas ARHD.

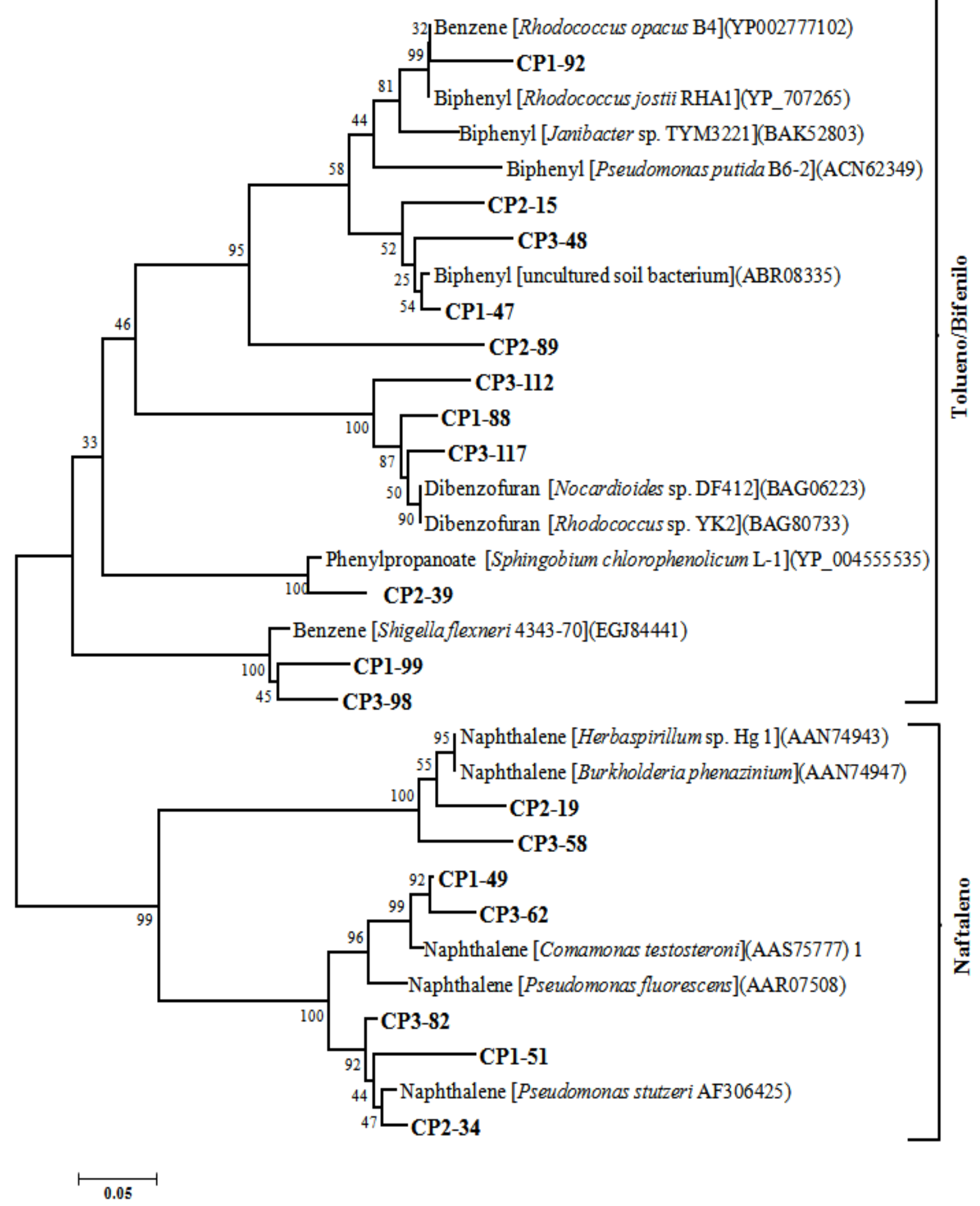

Árvore gerada com o método de Neighbor-Joining, pelo modelo de substituição de resíduos de aminoácidos por Matriz PAM (Dayhoff) e valor de bootstrap de 1.000 repetições. A escala indica a porcentagem de divergência entre as seqüências. 
Para Yeates e colaboradores (2000) as diferenças das seqüências de oxigenases e da diversidade na estrutura das comunidades microbianas de solos contaminados e protegidos, podem ser reflexos tanto de efeitos geográficos, como de diferenças nos substratos nos dois locais. A extensão de substratos e a diversidade bioquímica de enzimas desconhecidas parece ser maior do que a observada em enzimas já descritas, destacando-se o potencial biotecnológico de organismos ainda não cultivados.

Utilizamos o software MOTHUR para agrupar as bibliotecas do gene $\alpha$-ARHD baseando-se na distância filogenética, considerando de 80 a $97 \%$ de identidade entre as seqüências do mesmo grupo no nível de aminoácidos (cutoffs 0,03;0,05;0,10 e 0,20). Considerando-se o cutoff de 0,05 verifica-se na Tabela 4 que o Manguezal que apresentou o maior número de OPFs foi Bertioga Contaminado $(n=22)$. Foram identificados para este manguezal de Bertioga Contaminado 11 grupos distintos (OPFs) para BC1, 9 grupos para BC2 e 14 grupos para BC3 (Tabela 6). Verifica-se que o elevado valor de OPFs em Bertioga Contaminado se dá devido ao ponto BC3, que foi aquele que apresentou os maiores números de OPFs dentre todos os pontos amostrados. Para Bertioga Antropizado verificou-se 4 grupos para a biblioteca BA1, 12 grupos para BA2 e 5 grupos para BA3 (Tabela 5). Para Cananéia foi observada uma distribuição mais homogênea com 8 grupos para CP1, 7 grupos para CP2 e 9 grupos para CP3, conforme mostrado na Tabela 7.

Para melhor compreender as relações entre as populações bacterianas degradadoras de compostos aromáticos presentes nos sedimentos dos manguezais amostrados, todas as bibliotecas foram analisadas em função de sua heterogeneidade. As Tabelas 4 a 7 apresentam as medidas de diversidade calculadas para as bibliotecas do gene $\alpha$-ARHD analisadas neste estudo, dadas em função dos estimadores de riqueza de espécies, dos índices de diversidade e porcentagem de cobertura. Os resultados obtidos indicaram que o número de seqüências do gene $\alpha$-ARHD foram suficientes para amostrar completamente a riqueza de espécies das comunidades microbianas destes manguezais em um cutoff de 0,05, especialmente para os pontos BA1, BA3, BC2, CP1 e CP3 (Figuras 23 e 24).

Os valores dos índices de Chao1 e ACE demonstraram que, de modo geral, as bibliotecas de Bertioga apresentaram maior riqueza que Cananéia, sendo que a biblioteca de Bertioga Antropizado, especialmente o ponto BA2, apresentou maior riqueza que as demais. A biblioteca BA1, devido à dominância da enzima bifenilo dioxigenase, apresentou as menores medidas de riqueza. Os índices de Shannon e Simpson revelaram maior diversidade na biblioteca de Bertioga Contaminado, sendo que BC3 foi aquele com maior diversidade dentre todos os pontos amostrados. 
Tabela 4. Número de OPFs e índices de alfa-diversidade estimados para as sequências de aminoácidos obtidas através do sequenciamento para o gene $\alpha$-ARHD para cada manguezal.

\begin{tabular}{ccccccccc}
\hline \multirow{2}{*}{ Biblioteca } & \multirow{2}{*}{$\mathbf{N}^{\mathbf{0}}$ Seqs } & \multirow{2}{*}{ Cutoff } & \multirow{2}{*}{ OPFs } & \multicolumn{2}{c}{ Riqueza } & \multicolumn{2}{c}{ Diversidade } & Cobertura \\
Chao1 & ACE & Shannon & Simpson & \% \\
\hline \multirow{4}{*}{ BA } & \multirow{3}{*}{389} & 0,03 & 28 & 51 & 58 & 2,60 & 0,105 & 0,97 \\
& & $\mathbf{0 , 0 5}$ & $\mathbf{1 3}$ & $\mathbf{2 3}$ & $\mathbf{4 6}$ & $\mathbf{1 , 7 9}$ & $\mathbf{0 , 2 0 0}$ & $\mathbf{0 , 9 9}$ \\
& & 0,10 & 6 & 7 & 1 & 0,79 & 0,611 & 1,00 \\
& & 0,20 & 5 & 6 & 1 & 0,72 & 0,616 & 1,00 \\
& & 0,03 & 35 & 37 & 37 & 3,21 & 0,047 & 0,99 \\
$\mathbf{B C}$ & \multirow{3}{*}{386} & $\mathbf{0 , 0 5}$ & $\mathbf{2 2}$ & $\mathbf{2 3}$ & $\mathbf{2 3}$ & $\mathbf{2 , 7 2}$ & $\mathbf{0 , 0 8 3}$ & $\mathbf{0 , 9 9}$ \\
& & 0,10 & 14 & 14 & 14 & 2,00 & 0,203 & 1,00 \\
& & 0,20 & 11 & 11 & 11 & 1,84 & 0,220 & 1,00 \\
& & 0,03 & 25 & 26 & 26 & 2,95 & 0,060 & 0,99 \\
$\mathbf{C P}$ & \multirow{3}{*}{344} & $\mathbf{0 , 0 5}$ & $\mathbf{1 5}$ & $\mathbf{1 6}$ & $\mathbf{1 6}$ & $\mathbf{2 , 0 8}$ & $\mathbf{0 , 1 8 2}$ & $\mathbf{0 , 9 9}$ \\
& & 0,10 & 12 & 13 & 13 & 1,63 & 0,284 & 1,00 \\
& & 0,20 & 10 & 10 & 10 & 1,59 & 0,285 & 1,00 \\
\hline
\end{tabular}

Tabela 5. Número de OPFs e índices de alfa-diversidade estimados para as sequências de aminoácidos obtidas através do sequenciamento para o gene $\alpha$-ARHD para os pontos amostrais do manguezal de Bertioga Antropizado.

\begin{tabular}{lcccccccc}
\hline \multirow{2}{*}{ Biblioteca } & \multirow{2}{*}{$\mathbf{N}^{\mathbf{0}}$ Seqs } & Cutoff & \multirow{2}{*}{ OPFs } & \multicolumn{2}{c}{ Riqueza } & \multicolumn{2}{c}{ Diversidade } & \multicolumn{2}{c}{ Cobertura } \\
Chao1 & ACE & Shannon & Simpson & \% \\
\hline \multirow{4}{*}{ BA1 } & \multirow{3}{*}{142} & 0,03 & 11 & 11 & 11 & 2,0 & 0,190 & 1,00 \\
& & $\mathbf{0 , 0 5}$ & $\mathbf{4}$ & $\mathbf{4}$ & $\mathbf{4}$ & $\mathbf{1 , 0}$ & $\mathbf{0 , 4 2 0}$ & $\mathbf{1 , 0 0}$ \\
& & 0,10 & 1 & 1 & 1 & 0,1 & 1,000 & 1,00 \\
& & 0,20 & 1 & 1 & 1 & 0,1 & 1,000 & 1,00 \\
BA2 & \multirow{3}{*}{134} & 0,03 & 24 & 47 & 45 & 2,7 & 0,076 & 0,93 \\
& & 0,05 & $\mathbf{1 2}$ & $\mathbf{2 0}$ & $\mathbf{2 3}$ & $\mathbf{1 , 7}$ & $\mathbf{0 , 2 2 0}$ & $\mathbf{0 , 9 6}$ \\
& & 0,10 & 6 & 7 & 14 & 1,0 & 0,416 & 0,99 \\
& & 0,20 & 5 & 6 & 1 & 0,9 & 0,418 & 1,00 \\
BA3 & \multirow{2}{*}{113} & 0,03 & 9 & 9 & 9 & 2,0 & 0,154 & 1,00 \\
& & $\mathbf{0 , 0 5}$ & $\mathbf{5}$ & $\mathbf{5}$ & $\mathbf{5}$ & $\mathbf{1 , 3}$ & $\mathbf{0 , 3 4 5}$ & $\mathbf{1 , 0 0}$ \\
& & 0,10 & 3 & 3 & 3 & 0,7 & 0,611 & 1,00 \\
& & 0,20 & 2 & 2 & 0,1 & 0,6 & 0,633 & 1,00 \\
\hline
\end{tabular}


Tabela 6. Número de OPFs e índices de alfa-diversidade estimados para as sequências de aminoácidos obtidas através do sequenciamento para o gene $\alpha$-ARHD para os pontos amostrais do manguezal de Bertioga Contaminado.

\begin{tabular}{|c|c|c|c|c|c|c|c|c|}
\hline \multirow{2}{*}{ Biblioteca } & \multirow{2}{*}{$N^{0}$ Seqs } & \multirow{2}{*}{ Cutoff } & \multirow{2}{*}{ OPFs } & \multicolumn{2}{|c|}{ Riqueza } & \multicolumn{2}{|c|}{ Diversidade } & \multirow{2}{*}{$\begin{array}{c}\text { Cobertura } \\
\%\end{array}$} \\
\hline & & & & Chao1 & ACE & Shannon & Simpson & \\
\hline \multirow{4}{*}{ BC1 } & \multirow{4}{*}{106} & 0,03 & 20 & 25 & 28 & 2,47 & 0,106 & 0,95 \\
\hline & & 0,05 & 11 & 17 & 15 & 1,70 & 0,259 & 0,96 \\
\hline & & 0,10 & 5 & 5 & 7 & 1,05 & 0,395 & 0,99 \\
\hline & & 0,20 & 4 & 4 & 1 & 1,00 & 0,399 & 1,00 \\
\hline \multirow{4}{*}{ BC2 } & \multirow{4}{*}{144} & 0,03 & 13 & 13 & 13 & 2,26 & 0,123 & 1,00 \\
\hline & & 0,05 & 9 & 9 & 9 & 1,94 & 0,162 & 1,00 \\
\hline & & 0,10 & 5 & 5 & 5 & 0,95 & 0,527 & 1,00 \\
\hline & & 0,20 & 4 & 4 & 4 & 0,79 & 0,553 & 1,00 \\
\hline \multirow{4}{*}{ ВC3 } & \multirow{4}{*}{136} & 0,03 & 15 & 15 & 15 & 2,50 & 0,093 & 0,97 \\
\hline & & 0,05 & 14 & 14 & 14 & 2,43 & 0,097 & 0,98 \\
\hline & & 0,10 & 12 & 12 & 12 & 2,20 & 0,127 & 0,99 \\
\hline & & 0,20 & 10 & 10 & 10 & 2,04 & 0,149 & 1,00 \\
\hline
\end{tabular}

Tabela 7. Número de OPFs e índices de alfa-diversidade estimados para as sequências de aminoácidos obtidas através do sequenciamento para o gene $\alpha$-ARHD para os pontos amostrais do manguezal de Cananéia.

\begin{tabular}{lcccccccc}
\hline \multirow{2}{*}{ Biblioteca } & \multirow{2}{*}{$\mathbf{N}^{\mathbf{0}}$ Seqs } & Cutoff & \multirow{2}{*}{ OPFs } & \multicolumn{2}{c}{ Riqueza } & \multicolumn{2}{c}{ Diversidade } & Cobertura \\
Chao1 & & & ACE & Shannon & Simpson & \% \\
\hline \multirow{4}{*}{ CP1 } & \multirow{2}{*}{123} & 0,03 & 14 & 14 & 14 & 2,50 & 0,087 & 1,00 \\
& & $\mathbf{0 , 0 5}$ & $\mathbf{8}$ & $\mathbf{8}$ & $\mathbf{8}$ & $\mathbf{1 , 7 2}$ & $\mathbf{0 , 2 2 6}$ & $\mathbf{1 , 0 0}$ \\
& & 0,10 & 7 & 7 & 7 & 1,32 & 0,405 & 1,00 \\
& & 0,20 & 7 & 7 & 7 & 1,32 & 0,405 & 1,00 \\
$\mathbf{C P 2}$ & \multirow{3}{*}{104} & 0,03 & 13 & 15 & 22 & 2,10 & 0,147 & 0,96 \\
& & 0,05 & $\mathbf{7}$ & $\mathbf{8}$ & $\mathbf{2}$ & $\mathbf{1 , 5 6}$ & $\mathbf{0 , 2 4 3}$ & $\mathbf{0 , 9 8}$ \\
& & 0,10 & 5 & 6 & 1 & 0,98 & 0,452 & 0,98 \\
& & 0,20 & 4 & 4 & 1 & 0,94 & 0,454 & 1,00 \\
$\mathbf{C P 3}$ & \multirow{2}{*}{117} & 0,03 & 13 & 13 & 13 & 2,45 & 0,085 & 0,99 \\
& & $\mathbf{0 , 0 5}$ & $\mathbf{9}$ & $\mathbf{9}$ & $\mathbf{9}$ & $\mathbf{1 , 9 8}$ & $\mathbf{0 , 1 6 1}$ & $\mathbf{1 , 0 0}$ \\
& & 0,10 & 7 & 7 & 7 & 1,65 & 0,236 & 1,00 \\
& & 0,20 & 7 & 7 & 7 & 1,65 & 0,236 & 1,00 \\
\hline
\end{tabular}


Figura 23. Curvas de rarefação estimadas para o número total de sequências do gene $\alpha$ ARHD de cada manguezal para os cutoffs de 0,03; 0,05; 0,10 e 0,20.
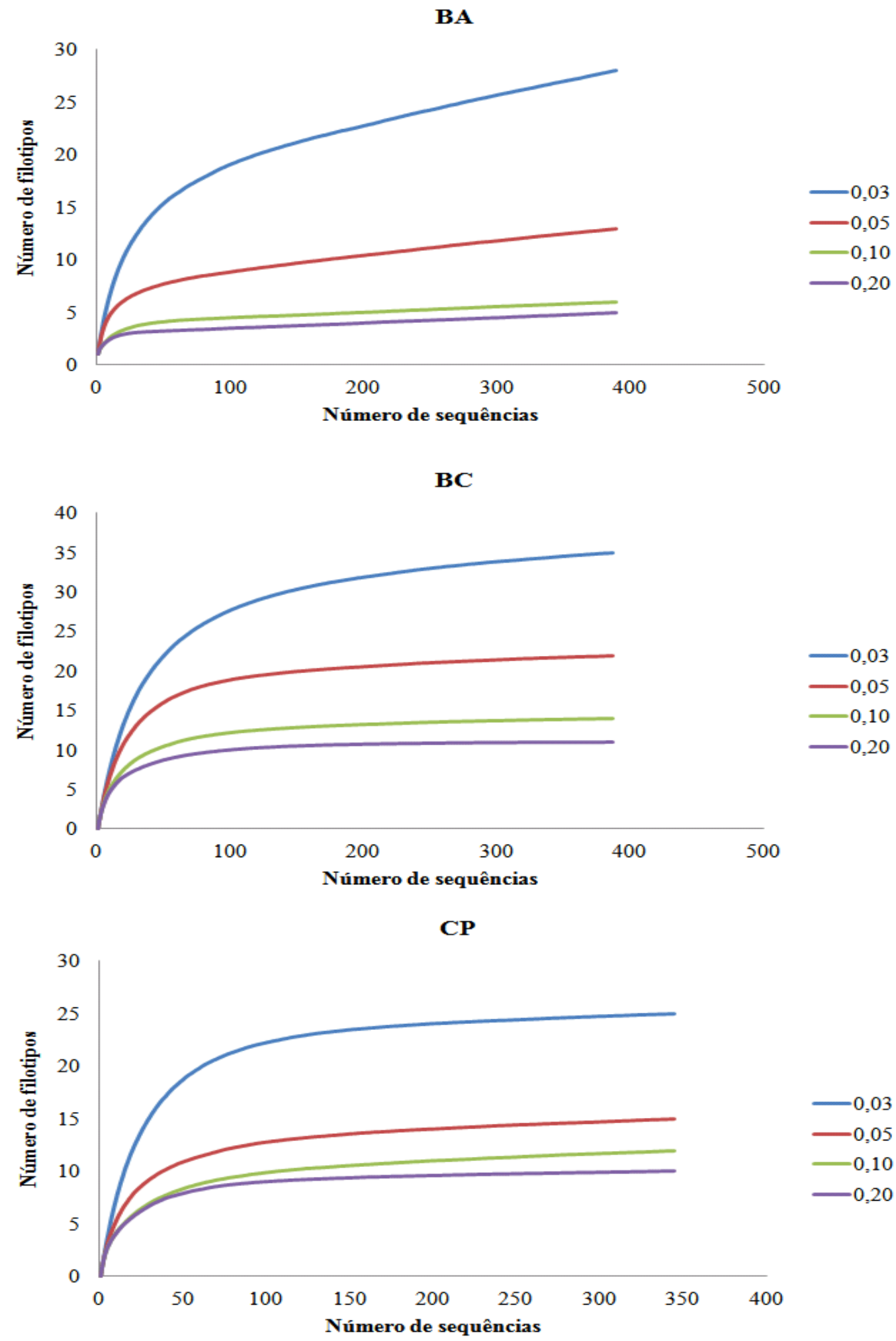

Ordenada: número de OPFs; Abscissa: número de sequências analisadas. 
Figura 24. Curvas de rarefação estimadas para o número total de sequências do gene $\alpha$ ARHD para cada ponto amostral para os cutoffs de 0,03; 0,05; 0,10 e 0,20.
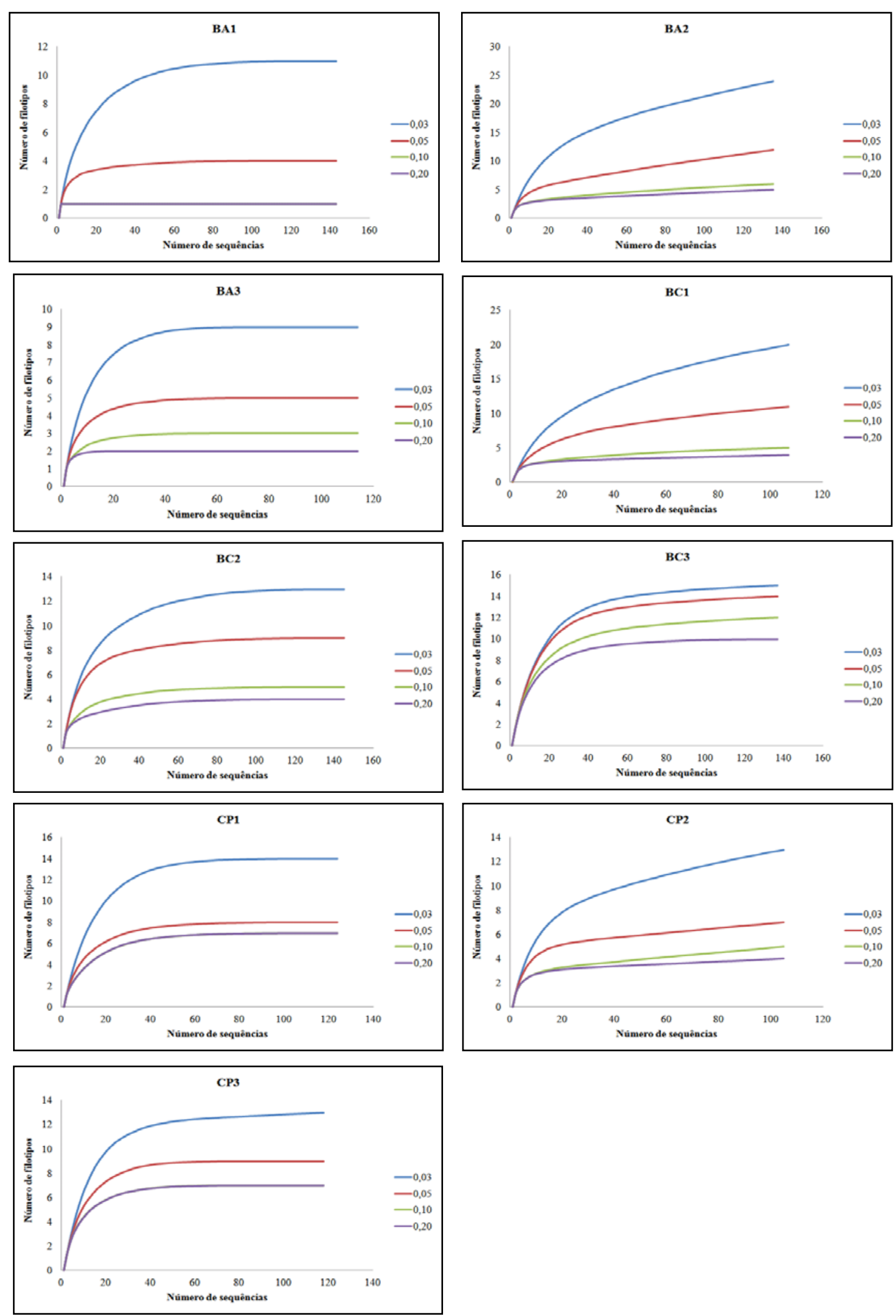

Ordenada: número de OPFs; Abscissa: número de sequências analisadas. 
Em nosso estudo a comparação da estrutura da comunidade por métodos baseados em OPFs foi realizada para quantificar a riqueza compartilhada observada (Sharedsobs) e estimada (Sharedace e Sahredchao) entre as amostras. Estes índices de beta-diversidade foram calculados entre as amostras de sedimento dos três manguezais analisados para um cutoff de 0,05. Fica claro na Tabela 8 que os índices de riqueza compartilhada observada e estimada foram maiores quando as amostras BC1 foram comparadas a BC2.

A similaridade dos membros da comunidade, quanto a sua estrutura, foi medida através dos coeficientes de abundância de Jaccard (Jclass) e Theta de Yue-Clayton (Thetayc). Também de acordo com estes coeficientes os pontos amostrais BC1 e BC2 foram os que apresentaram maior similaridade entre si com relação às comunidades microbianas.

Tabela 8. Índices de beta-diversidade calculados entre as amostras dentro de cada manguezal para o cutoff de 0,05 .

\begin{tabular}{llccccc}
\hline \multirow{2}{*}{$\begin{array}{c}\text { Amostras } \\
\text { comparadas }\end{array}$} & \multicolumn{5}{c}{ Índices de beta-diversidade* } \\
\cline { 3 - 7 } & Sharedsobs & Sharedace & Sharedchao & Jclass & Thetayc \\
\hline BA1 & BA2 & 3,0 & 3,0 & 3,0 & 0,23 & 0,32 \\
BA1 & BA3 & 2,0 & 2,0 & 2,0 & 0,29 & 0,84 \\
BA2 & BA3 & 4,0 & 4,0 & 4,0 & 0,31 & 0,26 \\
BC1 & BC2 & $\mathbf{7 , 0}$ & $\mathbf{6 , 0}$ & $\mathbf{8 , 0}$ & $\mathbf{0 , 5 4}$ & $\mathbf{0 , 1 4}$ \\
BC1 & BC3 & 3,0 & 4,1 & 4,0 & 0,14 & 0,02 \\
BC2 & BC3 & 3,0 & 3,0 & 3,0 & 0,15 & 0,09 \\
CP1 & CP2 & 3,0 & 3,0 & 3,0 & 0,25 & 0,32 \\
CP1 & CP3 & 5,0 & 5,0 & 5,0 & 0,42 & 0,70 \\
CP2 & CP3 & 4,0 & 4,0 & 4,0 & 0,33 & 0,42 \\
\hline
\end{tabular}

*Sharedsobs: número de OPFs compartihadas observadas; Sharedace: índice de ACE compartilhado; Sharedchao: índice de Chao1 compartilhado; Jclass: coeficiente de similaridade de Jaccard; Thetayc: coeficiente de similaridade theta de Yue-Clayton.

Fonte: Lima (2012).

Com o intuito de melhor representar os resultados das análises de riqueza compartilhada entre as amostras e também entre os manguezais, foram gerados diagramas de Venn para verificar as intersecções e peculiaridades de cada ambiente, identificando o número de OPFs exclusivas e compartilhadas entre os diferentes manguezais (Figura 25). Através dessa análise foi possível observar uma maior quantidade de OPFs únicas nas bibliotecas de Bertioga Contaminado em comparação com os demais manguezais amostrados, também fica evidente que esses manguezais não compartilham sequencias do gene $\alpha$-ARHD entre si. Esses 
resultados confirmam que o impacto ambiental sofrido pelo manguezal de Bertioga (BC) pode ter influenciado diretamente no aumento da diversidade funcional da comunidade microbiana que apresenta o gene $\alpha$-ARHD nesse ecossistema.

Considerando-se apenas os pontos amostrados dentro dos diferentes manguezais, observa-se que os pontos BA1, BA3 e BC2 são aqueles que apresentaram o menor número de seqüências únicas.

Figura 25. Diagramas de Venn baseados nas OPFs das bibliotecas do gene $\alpha$-ARHD (cutoff $0,05)$.

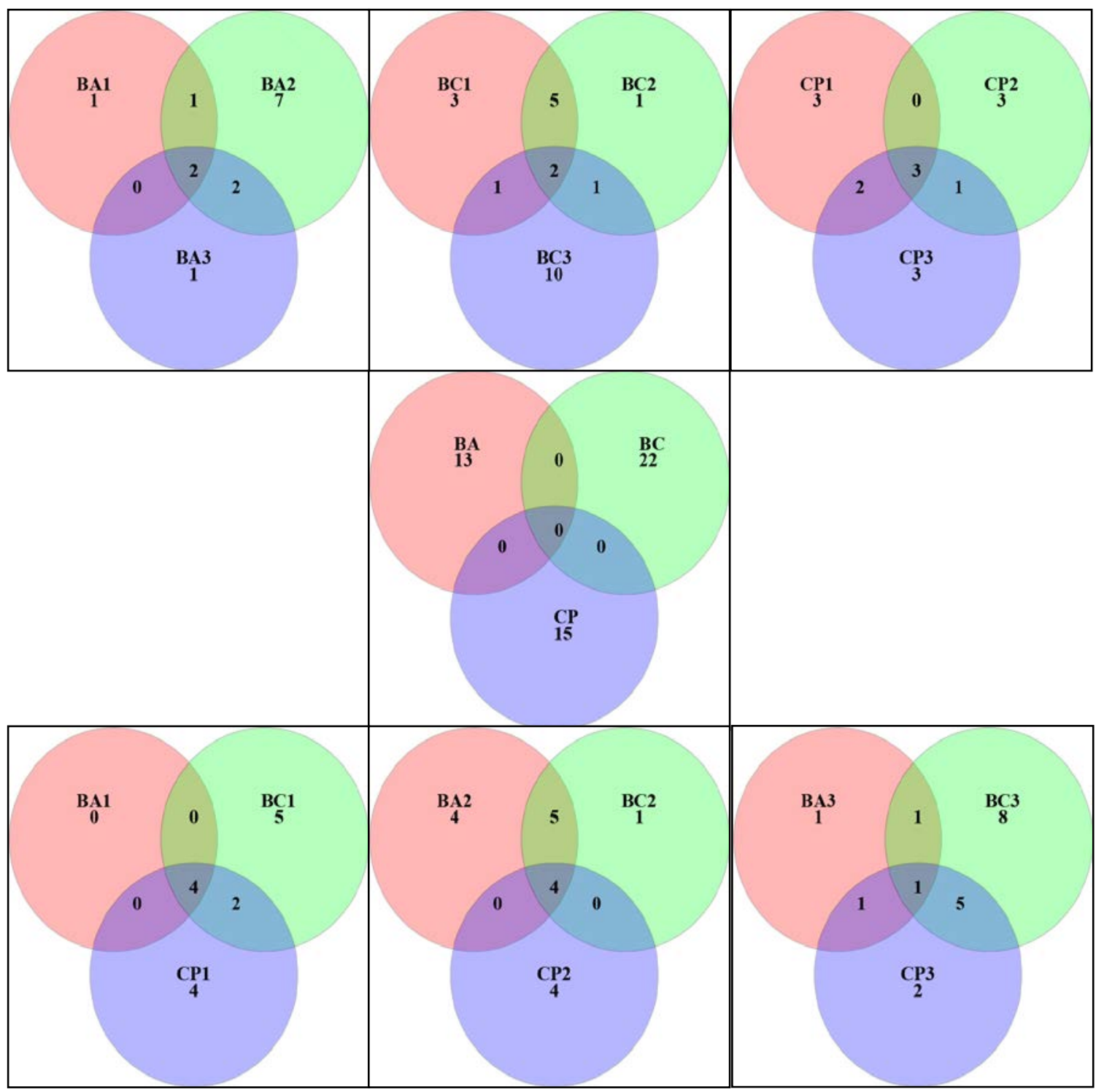

O diagrama ao centro representa a análise entre manguezais (BA-BC-CP). Os diagramas na parte superior representam a análise dentro de cada manguezal (BA), (BC), (CP) e aqueles na parte inferior representam a análise considerando os pontos (P1), (P2), (P3) nos diferentes manguezais. 
A beta diversidade também foi estimada através de testes de hipóteses e o teste empregado foi o Libshuff que testa a hipótese de subamostragens para estimar as diferenças entre cada comunidade, avaliando se a primeira comunidade é subamostra da segunda. Em cada comparação, um valor de p (p-value) é gerado e, caso esteja abaixo do $p$ crítico, a hipótese é rejeitada. Os resultados do teste de Libshuff estão apresentados na Tabela 9 e o pvalue foi significativo para todos os pares de amostras analisados. Mais especificamente, o teste revelou que todas as amostras são diferentes entre si, confirmando os resultados anteriores.

Tabela 9. Teste de hipótese Libshuff entre as amostras dos três manguezais, sob um cutoff de 0,05 .

\begin{tabular}{cccl}
\hline $\begin{array}{c}\text { Amostras } \\
\text { Comparadas }\end{array}$ & dCXYScore & $\begin{array}{c}\text { Significância } \\
(\boldsymbol{p} \text {-value })\end{array}$ & Resultado $^{\mathbf{v}}$ \\
\hline BA-BC & 0.74619548 & $<0.0001$ & Significativo \\
BC-BA & 0.73642516 & $<0.0001$ & Significativo \\
BA-CP & 0.77324106 & $<0.0001$ & Significativo \\
CP-BA & 0.77593923 & $<0.0001$ & Significativo \\
BC-CP & 0.66534500 & $<0.0001$ & Significativo \\
CP-BC & 0.65615427 & $<0.0001$ & Significativo \\
BA1-BA2 & 0.00188990 & 0.0004 & Significativo \\
BA2-BA1 & 0.12811454 & $<0.0001$ & significativo \\
BA1-BA3 & 0.00657593 & $<0.0001$ & significativo \\
BA3-BA1 & 0.03874737 & $<0.0001$ & significativo \\
BA2-BA3 & 0.06100981 & $<0.0001$ & significativo \\
BA3-BA2 & 0.00931445 & $<0.0001$ & significativo \\
BC1-BC2 & 0.01710676 & $<0.0001$ & significativo \\
BC2-BC1 & 0.01496848 & $<0.0001$ & significativo \\
BC1-BC3 & 0.09580965 & $<0.0001$ & significativo \\
BC3-BC1 & 0.17723666 & $<0.0001$ & significativo \\
BC2-BC3 & 0.02135286 & $<0.0001$ & significativo \\
BC3-BC2 & 0.17254232 & $<0.0001$ & Significativo \\
CP1-CP2 & 0.02950152 & $<0.0001$ & Significativo \\
CP2-CP1 & 0.01029189 & $<0.0001$ & Significativo \\
CP1-CP3 & 0.01328148 & $<0.0001$ & Significativo \\
CP3-CP1 & 0.02538953 & $<0.0001$ & Significativo \\
CP2-CP3 & 0.00796606 & $<0.0001$ & Significativo \\
CP3-CP2 & 0.04268200 & $<0.0001$ & Significativo \\
\hline
\end{tabular}

${ }^{1}$ Significativo se $\mathrm{p}<0,0083$ 
A alteração da diversidade de genes catabólicos numa comunidade microbiana pode ser resultado de diversos estímulos abióticos, como alterações no clima, mudanças na prática de uso do solo, desmatamentos ou introdução de compostos poluentes no ambiente, além de fatores bióticos, como transferência horizontal de genes. Os ecossistemas costeiros são ambientes influenciados por processos continentais e marinhos, que interagem através de variáveis físicas, químicas, biológicas, climáticas e antrópicas, as quais se inter-relacionam de maneira complexa, estabelecendo um equilíbrio dinâmico. A supressão de grupos microbianos ou micro-organismos ativos tem um efeito deletério na ciclagem dos nutrientes no ambiente em questão (EL-TARABILY, 2002).

Ainda existem lacunas importantes no conhecimento sobre a estrutura e diversidade de enzimas ARHD em amostras ambientais, fato que torna difícil a classificação dentro de uma abordagem funcional. Ainda mais escassos são os estudos com estas enzimas em ambiente de manguezal, geralmente são observadas apenas variações no gene 16S rRNA. Talvez em função disso algumas seqüências encontradas em nossa pesquisa não puderam ser diretamente relacionadas com grupos enzimáticos descritos previamente, podendo constituir novas enzimas associadas a este ambiente específico. Estudos posteriores serão necessários para a confirmação desta hipótese.

Em um estudo realizado por Gomes et al. (2007) com amostras de manguezais urbanos na da Baía da Guanabara (Rio de Janeiro) foram propostos, pelo uso da PRC-DGGE, três novos genes relacionados à biodegradação de naftaleno, sendo dois deles encontrados em ambiente com baixos níveis de contaminação por HPAs e um dos novos genes foi detectado em manguezal com elevada contaminação por HPAs. Os resultados deste trabalho corroboram com a ideia de que novas dioxigenases podem ser encontradas nos ambientes de manguezais, tendo em vista que poucos estudos utilizando estas enzimas são realizados nesses ecossistemas.

Em um trabalho conduzido com amostras de sedimento marinho de área preservada e contaminada na Antártica Kuhn (2007) verificou a presença das enzimas relacionadas ao grupo IV (Benzeno/Tolueno/Bifenilo dioxigenases) entre as 181 seqüências do gene $\alpha$-ARHD analisadas, além de seqüências gênicas ainda não conhecidas e relacionadas a seqüências de clones ambientais oriundos de regiões tropicais. A referida autora também propôs a presença de novos genes envolvidos na degradação de n-alcanos (KUHN et al., 2009).

Em nosso trabalho verificamos que a contaminação por HPAs pode ter interferido na diversidade funcional dos genes que codificam as ARHDs nos micro-organismos presentes nos sedimentos do manguezal de Bertioga (BC). A biblioteca do gene $\alpha$-ARHD do ambiente 
contaminado apresentou maior riqueza e diversidade de OPFs que a biblioteca do ambiente preservado. A maior diversidade de enzimas ARHDs observadas na amostra BC3 pode estar associada à alta variabilidade de substratos que foram inseridos naquele ponto, devido à contaminação por petróleo e seus subprodutos orgânicos, e a características físico-químicas do solo que pode ter favorecido a persistência destes compostos, o que provavelmente, ao longo dos anos, tem induzido uma forte variabilidade nos genes catabólicos ARHDs, especialmente pela troca de plasmídeos (transferência horizontal de genes) e por eventos como recombinação, duplicação, mutação pontual múltipla, deleção e integração gênica, proporcionando mobilidade gênica, maior versatilidade enzimática e acelerando o processo de degradação do contaminante naquele ambiente. 


\subsection{Isolados obtidos pelo enriquecimento com bifenilo}

Em nosso estudo todos os pontos amostrais analisados apresentaram crescimento microbiano, em meio Bushnell-Haas suplementado com bifenilo, após 21 dias de enriquecimento. Na diluição de $10^{-3}$ obtivemos um total de 36 isolados que apresentaram a capacidade de crescer com o bifenilo como única fonte de carbono. Destes isolados 21 apresentaram colônias morfologicamente distintas e foram selecionados para o sequenciamento do gene $16 \mathrm{~S}$ rRNA. Desse total 10 foram provenientes de Bertioga Antropizado, 10 de Bertioga Contaminado e 1 de Cananéia.

A partir da análise das sequências parciais $( \pm 500 \mathrm{pb})$ do gene $16 \mathrm{~S}$ rRNA foram definidos filotipos representativos de todos os gêneros bacterianos presentes em cada manguezal, com similaridade acima de $87 \%$ em relação ao banco de dados do Ribosomal Database Project (RDP). Os números de acesso, juntamente com a identidade em relação ao banco de dados e a referência de cada sequência representativa estão apresentados na Tabela 10 e Figura 26. A partir da identificação dos isolados obtidos para os diferentes manguezais, foi possível classificar todos os grupos filogenéticos em três filos distintos: Firmicutes (61\%), Proteobacteria (26\%) e Actinobacteria (13\%). Em Bertioga Antropizado as sequências nucleotídicas obtidas dos isolados foram similares a sequências dos gêneros Agromyces, Bacillus, Enterobacter, Lysinibacillus, Cellulomonas e Serratia. Em Bertioga Contaminado tivemos sequências similares a Bacillus, Lysinibacillus, Microbacterium, Ochrobactrum e Pseudomonas, enquanto que em Cananéia o único gênero encontrado foi Lysinibacillus.

Dentre esses isolados aqueles mais extensivamente citados por apresentar capacidade de degradação de diferentes bifenilos são Pseudomonas (Proteobacteria) e Bacillus (Firmicutes), isolados dos manguezais de Bertioga (FURUKAWA et al., 2008). O gênero Pseudomonas foi relacionado como hospedeiro do gene $\alpha$-ARHD envolvido na degradação de bifenilo na biblioteca obtida a partir da amostras de BC1 e foi aqui isolado. Esse microrganiso é altamente adaptado e amplamente distribuído na maioria dos ambientes e um microorganismo dominante entre os gêneros bacterianos envolvidos em processos funcionais de mineralização de hidrocarbonetos no solo (FURUKAWA \& FUJIHARA, 2008; FURUKAWA \& MIYAZAKI, 1986; JACQUES et al., 2005; KIMBARA et al., 1989; MA et al., 2006a).

A presença do gênero Bacillus nos mais diversos ambientes reflete a versatilidade metabólica destes micro-organismos que podem ser aeróbios ou anaeróbios facultativos, móveis e têm a capacidade de produzir endosporos altamente resistentes em resposta a 
estresse nutricional ou ambiental (ALCARAZ et al., 2010). Diferentes espécies do gênero Bacillus já foram reportados em vários trabalhos como sendo micro-organismos bastante eficientes na biodegradação de bifenilos e diversos congêneres de bifenilos policlorados (HATTA et al., 2003; MUKERJEE-DHAR et al., 2005; SHIMURA et al., 1999). O gênero Lysinibacillus, anteriormente classificado como Bacillus (AHMED et al., 2007) foi o único para o qual obtivemos isolados nos três manguezais analisados. Este gênero foi descrito por apresentar capacidade de degradação de dibenzotiofeno e cresol (BAHUGUNA et al., 2011; YAO et al., 2011) e de herbicidas (LIANG, B. et al., 2009), demonstrando uma grande versatilidade metabólica.

Tabela 10. Filotipos representativos dos gêneros bacterianos isolados a partir das amostras de sedimento dos manguezais enriquecidos com bifenilo.

\begin{tabular}{lccl}
\hline Isolado & Identidade & Sequência referência (Genbank) & \multicolumn{1}{c}{ Filo } \\
\hline BA1-1 & 0.996 & Cellulomonas sp. 3335BRRJ; (FJ200382.2) & Actinobacteria \\
BA1-2 & 0.975 & Enterococcus durans (T); (AJ276354) & Firmicutes \\
BA1-3 & 0.991 & Lysinibacillus fusiformis (T);(AJ310083) & Firmicutes \\
BA1-4 & 0.959 & Enterobacter ludwigii (T); (AJ853891) & Proteobacteria \\
BA2-1 & 0.989 & Agromyces mediolanus (T); (X77449) & Actinobacteria \\
BA2-2 & 0.991 & Bacillus cereus (T); (AE016877) & Firmicutes \\
BA2-3 & 0.875 & Lysinibacillus sphaericus (T); (AJ310084) & Firmicutes \\
BA2-4 & 0.976 & Bacillus thuringiensis (T); (D16281) & Firmicutes \\
BA3-1 & 0.960 & Serratia fonticola (T); (AJ233429) & Proteobacteria \\
BA3-2 & 1.000 & Lysinibacillus fusiformis (T); (AJ310083) & Firmicutes \\
BC1-1 & 0.980 & Bacillus thuringiensis (T); (D16281) & Firmicutes \\
BC1-2 & 0.963 & Lysinibacillus fusiformis (T); (AJ310083) & Firmicutes \\
BC1-3a & 1.000 & Ochrobactrum cytisi (T); (AY776289) & Proteobacteria \\
BC1-3b & 0.983 & Bacillus vietnamensis (T); (AB099708) & Firmicutes \\
BC1-4 & 0.989 & Pseudomonas sp; (AB009457) & Proteobacteria \\
BC2-1 & 0.970 & Microbacterium hydrocarbonoxydans (EU373354) & Actinobacteria \\
BC2-3 & 1.000 & Ochrobactrum cytisi (T); (AY776289) & Proteobacteria \\
BC3-1 & 0.983 & Bacillus vietnamensis (T); (AB099708) & Firmicutes \\
BC3-3b & 0.991 & Bacillus cereus (T); (AE016877) & Firmicutes \\
BC3-4 & 0.991 & Lysinibacillus fusiformis (T); (AJ310083) & Firmicutes \\
CP1-1 & 0.952 & Lysinibacillus fusiformis (T); (AJ310083) & Firmicutes \\
\hline
\end{tabular}


Figura 26. Árvore filogenética construída a partir das sequências parciais do gene 16S rRNA dos isolados e sequências de referência com maiores valores de identidade do banco de dados do RDP.

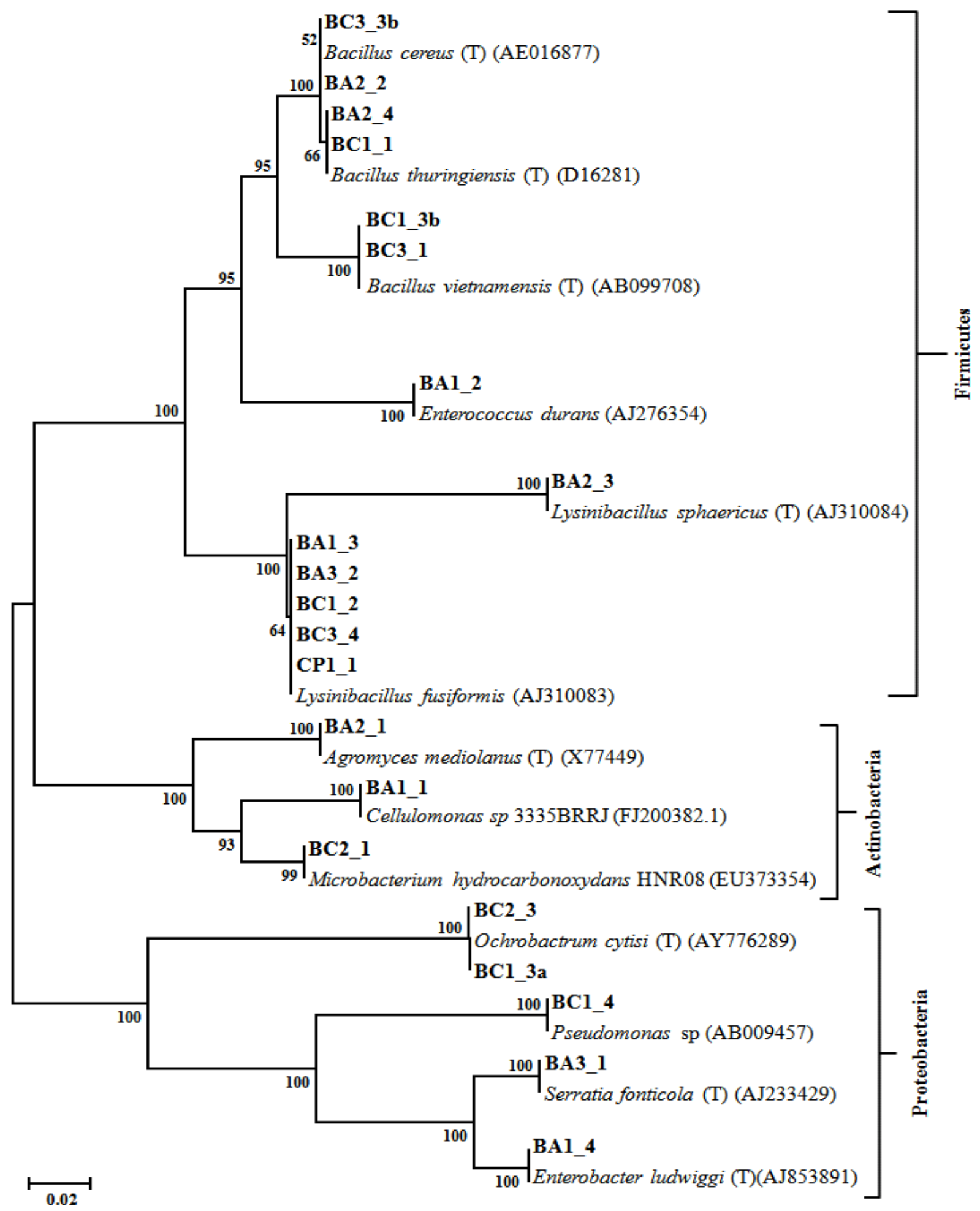

Árvore construída com o método Neighbor Joining, modelo Kimura 2-parâmetros e teste de 1.000 bootstraps. A escala indica a distância de similaridade dos ramos. Os isolados estão indicados em maiúsculas e negrito e com as iniciais do ponto amostral de onde foram obtidos. 
O gênero Ochrobactrum, encontrado em BC1 é um micro-organismo halotolerante, já foi isolado de solo contaminado com óleo (MOHEBALI et al., 2012) e descrito como produtor de biosurfactante (FERHAT et al., 2011) e degradador de HPAs como antraceno, fenantreno, fluoreno, pireno, benzo(k)fluoranteno e benzo(a)pireno (ARULAZHAGAN et al., 2011; WU, Y. et al., 2009). Esse gênero bacteriano também já foi isolado em enriquecimento com naftaleno e óleo cru a partir do manguezal de Bertioga em um trabalho conduzido por Reyes (2009), também já foi isolado por Silva (2011) pela capacidade de degradação de fenantreno a partir de amostras da Amazônia.

Em nosso estudo a família Enterobacteriaceae teve representantes dos gêneros Serratia e Enterobacter, além do gênero Pseudomonas, mencionado anteriormente. Bactérias do gênero Serratia já foram isoladas de áreas contaminadas com petróleo e mostraram grande eficiência em testes de biodegradação de gasolina, querosene, óleo diesel e óleos lubrificantes (WONGSA et al., 2004). Também existem relatos do gênero Serratia envolvido na biodegradação de asfaltenos (ROJAS-AVELIZAPA et al., 2002). Embora o gênero Enterobacter não esteja mencionado como micro-organismo tradicionalmente envolvido na degradação de HPAs, já foi descrito na biodegradação de 3,5,6-tricloro-2-pyridiol (FRENCH et al., 1998; SINGH et al., 2004) e mencionado em processos de biorremediação (SINGH et al., 2004).

Os gêneros Agromyces, Cellulomonas e Microbacterium, representantes do filo Actinobacteria, foram encontrados em ambos os manguezais de Bertioga. Estes microorganismos são aeróbios em sua maioria, ocorrem amplamente no solo, onde desempenham um relevante papel biológico e se caracterizam pela grande importância na produção de antibióticos (VENTURA et al., 2007). São reconhecidos como excelentes candidatos para aplicação em biorremediação de solos, pois utilizam uma ampla gama de fontes de carbono, degradam polímeros complexos como lignina e possuem a vantagem da formação de estruturas de resistência a estresse (endósporos) e produção de enzimas extracelulares, surfactantes e emulsificantes (PIZZUL et al., 2006), além da hidrofobicidade da superfície celular, que permite uma melhor adesão a compostos com baixa solubilidade em água (PIZZUL, LETICIA et al., 2007). O gênero Microbacterium hydrocarbonoxydans detectado no ponto BC2 foi obtido de solo contaminado com petróleo na Alemanha e descrito como um eficiente degradador de óleo cru (SCHIPPERS et al., 2005). A detecção deste gênero demonstra sua relevância, ao longo dos anos, na degradação dos hidrocarbonetos inseridos naquele ponto amostral por conta do derramamento. 
Peixoto et al. (2011) utilizaram diferentes amostras de um manguezal da Baía de Todos os Santos (Bahia) com histórico de exposição a óleo para verificar, pela utilização de métodos convencionais e moleculares, se a variação no perfil microbiológico refletia a variação do poluente. A autora constatou que os níveis totais de HPAs e de antraceno foram associados com o filo Actinobacteria, demonstrando que diferentes populações microbianas podem indicar o impacto por diferentes subprodutos do óleo.

Micro-organismos do gênero Enterococcus (Firmicutes), isolados neste estudo a partir de amostras do ponto BC1, são encontrados como membros da microbiota de humanos, animais e de amostras ambientais, geralmente associados à contaminação fecal (KIMIRANERDEM et al., 2007). Estes micro-organismos caracterizam-se por serem anaeróbios facultativos que suportam extremos de temperatura $\left(5,0-65{ }^{\circ} \mathrm{C}\right), \mathrm{pH}(4,5-10)$ e elevadas concentrações de $\mathrm{NaCl}$, além de uma resistência intrínseca (cromossomal) a uma gama de antibióticos incluindo vancomicina e aminoglicosídeos (FISHER et al., 2009) e resistência adquirida (plasmidial) a metais pesados como zinco (Zn), ferro (Fe), cádmio (Cd), cromo (Cr) e cobalto (Co) (KIMIRAN-ERDEM et al., 2007; MAZAHERI et al., 2011). Da mesma forma em que foi verificada uma correlação entre a resistência a antibióticos e a resistência a metais pesados como chumbo, mercúrio e arsênio em Enterococcus (NAKIPOGLU et al., 2009) acreditamos que micro-organismos deste gênero (possivelmente provenientes de lançamentos de esgoto), por conta de toda a versatilidade metabólica e resistência intrínseca e adquirida, tenham sido selecionados pela tolerância à presença de HPAs no ponto BA1, da mesma forma que o uso indiscriminado de antibióticos levou à seleção de cepas resistentes no ambiente hospitalar e a presença de metais pesados tem levado tais micro-organismos a apresentarem uma resistência adquirida a estes compostos. Estudos posteriores sobre a capacidade de degradação do isolado são necessários para sustentação desta hipótese.

Um fator importante a se considerar quando da presença de micro-organismos que não são tradicionalmente associados à biodegradação de um determinado composto, é a existência do co-metabolismo durante o processo de enriquecimento, que muitas vezes é essencial para a degradação completa de alguns HPAs, onde os sub-produtos do metabolismo inicial de um composto por determinado organismo servem de substrato para o crescimento de outras espécies (LEAHY et al., 1990; VAN HAMME et al., 2003).

Vários estudos têm sido realizados para obtenção de micro-organismos com potencial biotecnológico para biodegradação dos mais variados hidrocarbonetos aromáticos e uma grande diversidade de micro-organismos tem sido observada. Guo et al. (GUO et al., 2005) utilizaram amostras de sete manguezais em Hong Kong, com diferentes graus de 
contaminação, para obtenção de isolados capazes de crescer utilizando fenantreno como única fonte de carbono e energia. Neste estudo os autores isolaram bactérias dos gêneros Rhodococcus ruber, Sphingomonas sp. e Paracoccus versutus que foram identificadas pelo gene do rRNA $16 \mathrm{~S}$.

Em um estudo conduzido em cinco manguezais de Taiwan, Chang et al. (CHANG et al., 2008) isolaram seis bactérias que apresentaram capacidade para degradar uma mistura de fenantreno e pireno. Os micro-organismos foram identificados pelo gene rRNA 16S como Mycobacterium barrassi, Dyella ginsengisoli, Rhodococcus equi, Bacillus pumilus, Bacillus weihenstephanensis e Labrys sp. Neste estudo os autores verificaram, por cultivo direto, que diferentes comunidades microbianas estavam presentes em diferentes manguezais com diferentes concentrações de HPAs, sendo que a comunidade microbiana em ambientes com baixas concentrações de HPAs foi mais diversa que aquela encontrada nas elevadas concentrações destes compostos, sugerindo que a presença de altas concentrações de HPAs inibe parte da comunidade microbiana. Em nosso estudo a concentração de bifenilo utilizada pode ter inibido o isolamento de micro-organismos do manguezal de Cananéia.

Utilizando amostras de manguezais contaminado e preservado na Baía de Todos os Santos Taketani et al. (2010a) montaram microcosmos, que foram submetidos à contaminação com óleo, para verificar a resposta da comunidade microbiana de sedimentos com diferentes históricos de contaminação. Ambas as comunidades mostraram o aparecimento de novas bandas no DGGE em resposta à contaminação por óleo. As análises baseadas nas bibliotecas do gene 16S rRNA, construídas com amostras do início e fim do experimento, demonstraram que ambos os microcosmos apresentavam comunidades similares no início do experimento e elas foram se diferenciando da comunidade inicial, bem como diferenciando uma da outra, após 75 dias de contaminação. As diferenças observadas na estrutura da comunidade foram mais pronunciadas nas amostras do manguezal preservado. Tais resultados sugerem o papel do histórico ambiental (contato prévio com o óleo) no comportamento da comunidade microbiana em resposta a um estresse inserido por nova contaminação. Os filotipos presentes no mangue previamente impactado foram menos susceptíveis à mudança, indicando uma préseleção anterior, enquanto a comunidade do ambiente preservado teve que se adaptar, com alterações em sua estrutura, em resposta à contaminação.

Ramsay et al. (2000) também verificaram que a população de bactérias degradadoras de compostos aromáticos teve um aumento de $10^{4}$ para $10^{6}$ células por grama de sedimento após estímulo por adição de óleo em um estudo sobre biorremediação. 
Em nosso estudo maioria dos isolados identificados a partir do ensaio de enriquecimento já foi reportada na literatura como degradadores de algum tipo de hidrocarboneto aromático onde a fonte de isolamento foi relacionada a ambientes contaminados com esses compostos, como solos, sedimentos de manguezais, água e estações de tratamento de resíduos. Tal fato demonstra a confiabilidade do ensaio no isolamento de micro-organismos com potencial para biodegradação de bifenilos a partir de ambientes de manguezais, que podem constituir hot-spots de diversidade microbiana, principalmente com relação a processos metabólicos funcionais.

Os resultados aqui obtidos demonstram a influência dos diferentes fatores nas comunidades microbianas dos solos. Os dados de análises de hidrocarbonetos demonstraram uma maior concentração de HPAs nas amostras de Bertioga e da mesma forma foi possível observar uma maior frequência relativa de genes $\alpha$-ARHD e de isolados envolvidos na biodegradação de bifenilo nestes pontos amostrais.

Apesar das limitações da utilização do cultivo microbiano por conta da baixa representatividade de micro-organismos cultiváveis em relação aos ainda não cultiváveis, que em nosso estudo ainda foi direcionado pelo enriquecimento com um composto aromático e um meio seletivo para bactérias heterotróficas aeróbias e halotolerantes, este método convencional tornou possível determinar hospedeiros do gene de interesse, além disso, trouxe informações adicionais para fins de comparação dos ambientes, tendo em vista que no presente estudo, a quantidade de gêneros isolados foi aproximadamente dez vezes maior a partir das amostras de Bertioga contaminado em relação às amostras de Cananéia. 


\subsection{PCR em Tempo Real}

Neste estudo a PCR em tempo real foi utilizada para a medida da abundância do gene 16S rRNA e para a quantificação do gene $\alpha$-ARHD em amostras de sedimento de manguezais. Na quantificação do gene 16S rRNA, a temperatura de dissociação média foi $80^{\circ} \mathrm{C}$ e a eficiência de amplificação foi 1,04 com um valor de regressão logarítmica $\left(\mathrm{R}^{2}\right)$ de 0,99. Os resultados foram analisados considerando-se que múltiplas cópias do gene $16 \mathrm{~S}$ rRNA ocorrem por célula bacteriana. Para o gene $\alpha$-ARHD a temperatura de dissociação foi de $85,6{ }^{\circ} \mathrm{C}$ e a eficiência de amplificação foi de 0,94 com um valor de $\mathrm{R}^{2}$ de 0,98 . A especificidade de amplificação foi confirmada para ambos os genes por meio da presença de picos únicos nas análises de desnaturação (Figura 27) e por bandas únicas (com o tamanho esperado para ambos os genes) nos géis de agarose a que foram submetidos os produtos resultantes da PCR em tempo real.

De modo geral o número de cópias do gene 16S rRNA mostrou ter densidade mais homogênea nos diferentes manguezais e pontos amostrados, sendo que o número de cópias do gene por grama de sedimento variou de $8,48 \times 10^{10}$ a $1,18 \times 10^{12}$. No manguezal de Bertioga Antropizado os valores médios obtidos foram de: a) $1,18 \times 10^{12}$ no ponto BA1; b) $3,66 \times 10^{11}$

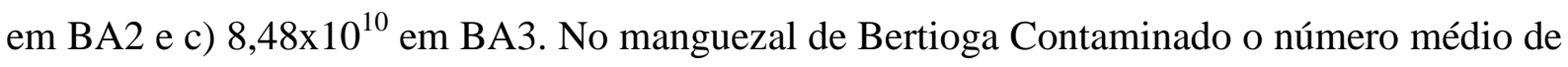
cópias do gene por grama de sedimento foi de: a) $3,43 \times 10^{11}$ no ponto $\mathrm{BC} 1$; b) $8,20 \times 10^{11} \mathrm{em}$ BC2 e c) 1,01x10 12 em BC3. Os valores médios obtidos para os pontos amostrais de Cananéia foram: a) $3,61 \times 10^{11}$ para CP1; b) $2,24 \times 10^{11}$ para CP2 e c) $3,45 \times 10^{11}$ para CP3.

Como esperado, os resultados obtidos com o gene $\alpha$-ARHD mostrou-se menos abundante que para o gene 16S rRNA, mas para o $\alpha$-ARHD foi possível observar uma maior diferenciação entre os manguezais, e o número médio de cópias do gene por grama de sedimento variou de $5,34 \times 10^{5}$ a $1,36 \times 10^{8}$. Pode-se verificar uma maior densidade de bactérias afiliadas a este grupo no manguezal de Bertioga Contaminado com petróleo, onde obtivemos: a) $1,08 \times 10^{6}$ no ponto BC1; b) $1,31 \times 10^{8}$ em BC2 e c) $1,36 \times 10^{8}$ em BC3. Vale enfatizar a maior concentração de HPAs também detectadas nos pontos BC2 e BC3. Já no manguezal de Bertioga Antropizado os valores médios obtidos foram de: a) $1,11 \times 10^{6}$ no ponto BA1; b) $1,23 \times 10^{7}$ em BA2 e c) $1,76 \times 10^{7}$ em BA3. As menores abundâncias do gene foram observadas no ambiente de Cananéia com: a) $5,34 \times 10^{5}$ para CP1; b) $6,79 \times 10^{5}$ para CP2 e c) $6,54 \times 10^{5}$ para CP3. 
Figura 27. Curvas de amplificação (A1 e B1), curvas de dissociação (A2 e B2) e curvaspadrão (A3 e B3) para confirmar a amplificação específica dos fragmentos dos genes 16S rRNA (A) e $\alpha$-ARHD (B) das amostras de sedimento dos manguezais.

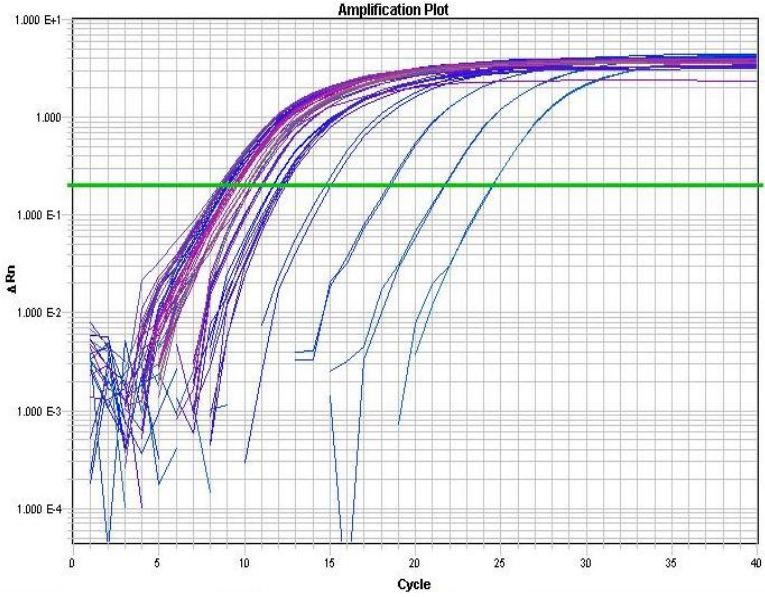

(A1)

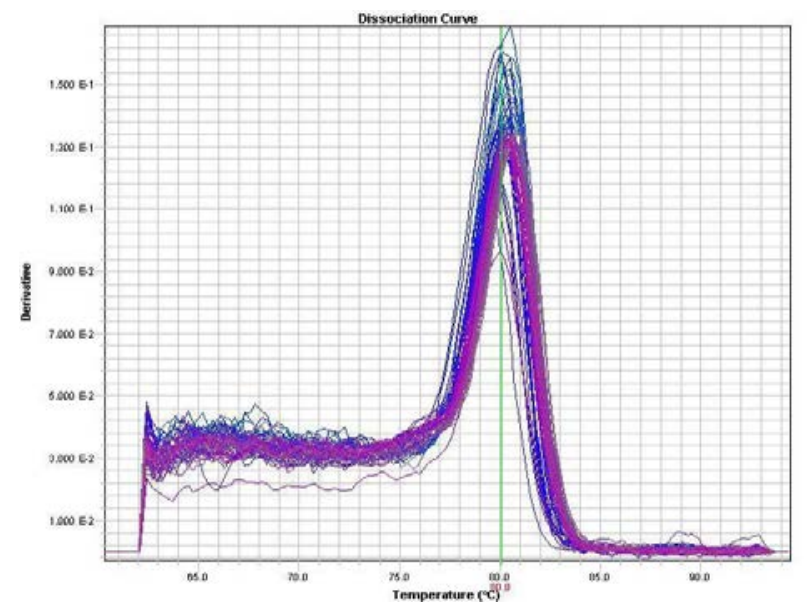

(A2)

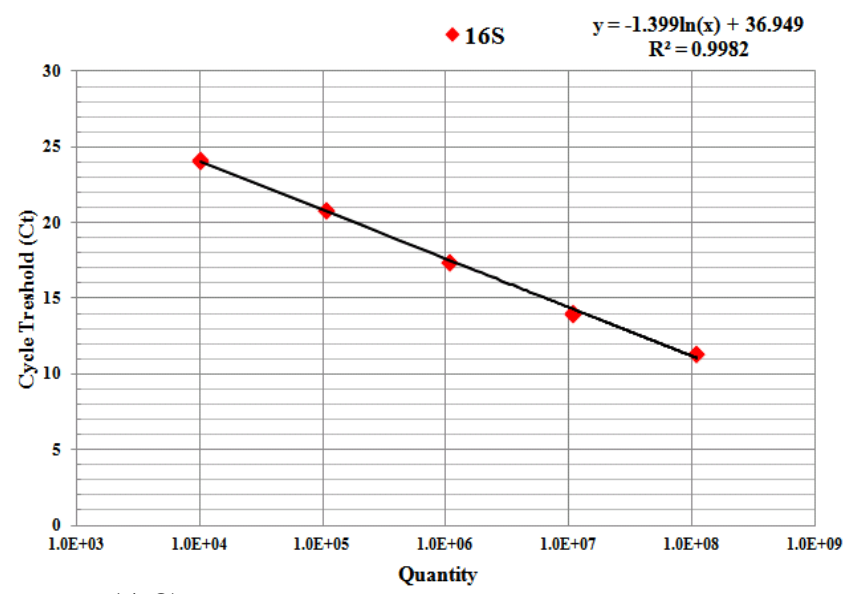

(A3)

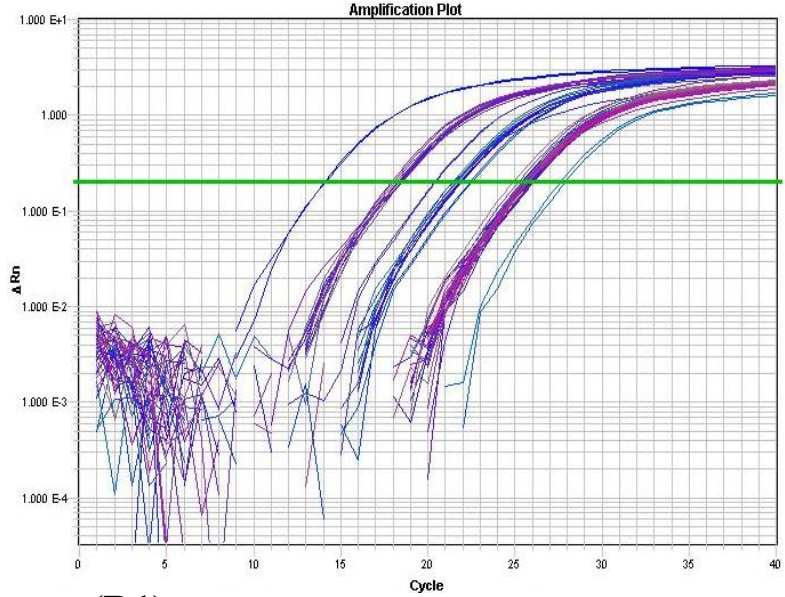

(B1)

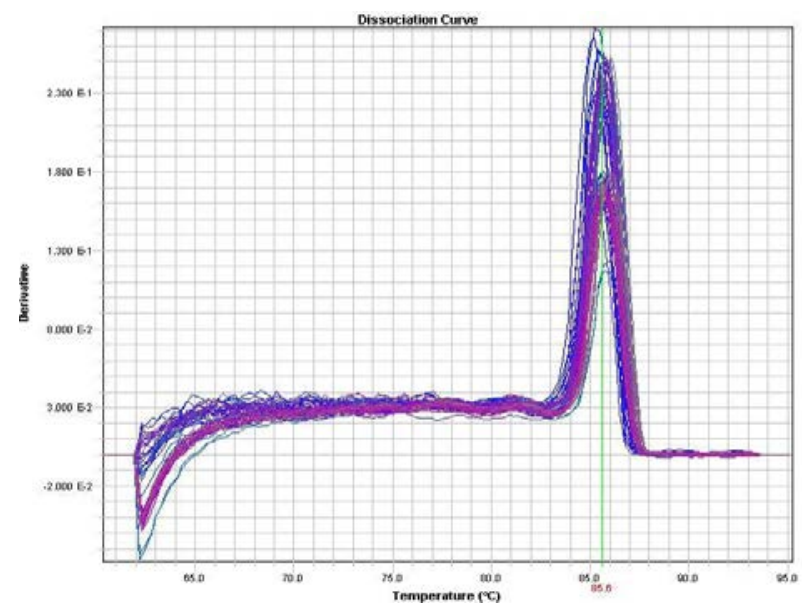

(B2)

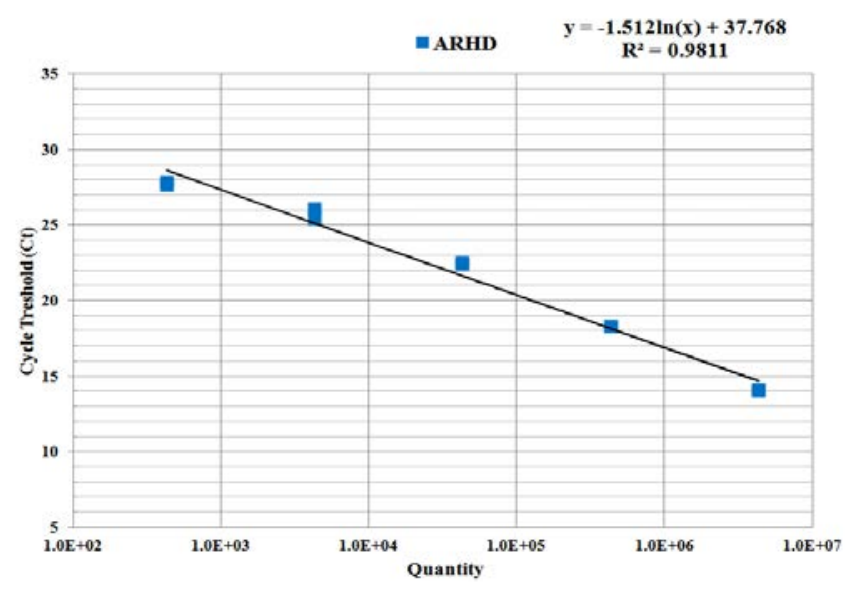

(B3) 
As enzimas associadas à degradação de hidrocarbonetos são bastante diversas e a maioria dos trabalhos de abundância de genes codificando estas enzimas foca grupos específicos como catecol 2,3-dioxigenase (MESARCH et al., 2000), benzil-succinato sintetase (BELLER et al., 2002), benzoil-CoA redutase (HOSODA et al., 2005), ou apenas verificam o limite de detecção da técnica, sem utilizar amostras ambientais (BALDWIN et al., 2003).

O naftaleno é frequentemente utilizado como composto modelo no estudo de biodegradação de hidrocarbonetos e aquele que apresenta maior número de literatura referente a PCR em tempo real. Dionisi et al. (2004) utilizaram a qPCR para quantificar o número de cópias do gene nagAc em nove diferentes amostras de sedimento previamente contaminadas com hidrocarbonetos. Os autores verificaram uma variação de $1,2 \times 10^{5}$ a $5,4 \times 10^{7}$ cópias do gene por grama de sedimento nas amostras analisadas.

Nyyssönem et al. (2006) utilizaram a PCR em tempo real em três amostras de solo da Finlândia com diferentes históricos de contaminação por hidrocarbonetos e detectaram as seguintes quantidades de cópias de genes nahAc (associados à degradação de naftaleno) por grama de solo: a) $1,2 \times 10^{6}$; b) $2,2 \times 10^{6}$ e c) $4,5 \times 10^{6}$. Assim como em nosso trabalho os autores observaram uma maior quantidade do gene na amostra de solo que apresentava a maior concentração total de HPAs. Os autores também validaram a técnica monitorando o aumento do número de cópias do gene correlacionando com a biodegradação do composto em experimentos envolvendo microcosmos.

Uma forma de comparar a quantidade de um gene funcional é por meio da razão (Log) obtida entre a abundância deste gene em relação ao 16S rRNA. Fazendo tal análise, observase que os pontos que apresentaram a maior razão $(0,68)$ representam BC2 e BC3 da região de Bertioga contaminada, o que corrobora com os dados obtidos de concentrações de Hidrocarbonetos, indicando que uma maior concentração destes compostos levou a população microbiana a uma maior versatilidade metabólica.

Cébron et al. (2008) utilizaram amostras de solo e sedimento da França e Bélgica para quantificar a comunidade bacteriana total e bactérias com capacidade de degradação de HPAs. O número de cópias do gene $16 \mathrm{~S}$ rRNA variou de $4,9 \times 10^{8}$ a $4,2 \times 10^{9}$ por grama de solo/sedimento enquanto o número de cópias de degradadores de hidrocarbonetos oscilou de $4,4 \times 10^{4}$ a $4,7 \times 10^{7}$ e a taxa de degradadores em relação à comunidade total ficou entre 0,01 a 0,92 .

Em nosso estudo a análise de variância (ANOVA) comprovou que os pontos amostrais de Cananéia (CP1, CP2 e CP3) não apresentaram diferenças significativas $(p \leq 0,05)$ entre si com relação número médio de cópias nas análises realizadas para os genes 16S e $\alpha$-ARHD. 
De forma geral, ao verificar os pontos amostrais que apresentaram diferenças significativas quanto ao número médio de cópias do gene 16S rRNA observa-se a presença de três perfis, representados pelas letras A (BA2, BC1, CP1, CP2 e CP3), B (BA3) e C (BA1, BC2 e BC3). Já a análise do gene $\alpha$-ARHD apresentou-se mais heterogênea, com quatro perfis representados pelas letras a (CP1, CP2 e CP3), b (BA1 e BC1), c (BC2 e BC3) e d (BA2 e BA3), como pode ser observado na Figura 28-I.

O que pode-se concluir pelo resultado da ANOVA dentro de cada manguezal é que: considerando-se o gene 16S rRNA verifica-se que em BA todos os pontos amostrais apresentaram diferenças significativas entre si, com a relação BA1>BA2>BA3. No manguezal BC o ponto BC1 (curso d’água) foi significativamente diferente dos pontos BC2 (floresta) e BC3 (restinga), obedecendo a relação BC2=BC3>BC1. Para o gene $\alpha$-ARHD observa-se que para ambos os manguezais (BA e BC) o ponto 1 (BA1 e BC1) foi significativamente diferente dos pontos 2 e 3 (BA2 e BA3) com a relação BA2=BA3>BA1 e $\mathrm{BC} 2=\mathrm{BC} 3>\mathrm{BC} 1$.

Quando realizamos a análise de variância (ANOVA) por manguezal (Figura 28-II), verificamos que com relação à média das abundâncias do gene 16S rRNA não existe diferença significativa $(p \leq 0,05)$ entre eles, enquanto que para o gene $\alpha$-ARHD os manguezais de Bertioga (BA e BC) são significativamente diferente de Cananéia. Estes resultados demonstram que, apesar da abundância da comunidade total nestes manguezais ser igual, houve um aumento significativo na abundância dos genes associados à codificação de enzimas envolvidas na biodegradação de hidrocarbonetos na comunidade bacteriana dos manguezais impactados.

Diante dos resultados aqui apresentados pode-se considerar que a PCR quantitativa representou uma robusta ferramenta para quantificar e comparar a comunidade bacteriana total e funcional de ambientes de manguezais impactados e preservado. Os resultados obtidos com a aplicação desta metodologia evidenciam que as áreas de manguezal estudadas abrigam uma abundante comunidade bacteriana e, além disso, enfatiza a resposta quantitativa da população funcional em relação às alterações ambientais sofridas, sugerindo que a contaminação do solo nos pontos BC2 e BC3 tem levado à seleção micro-organismos mais adaptados às fontes de hidrocarbonetos introduzidas no solo. 
Figura 28. Média da abundância dos genes $16 \mathrm{~S}$ rRNA e $\alpha$-ARHD pela técnica de qPCR, nos diferentes pontos amostrais analisados (I) e entre manguezais (II).

(I)

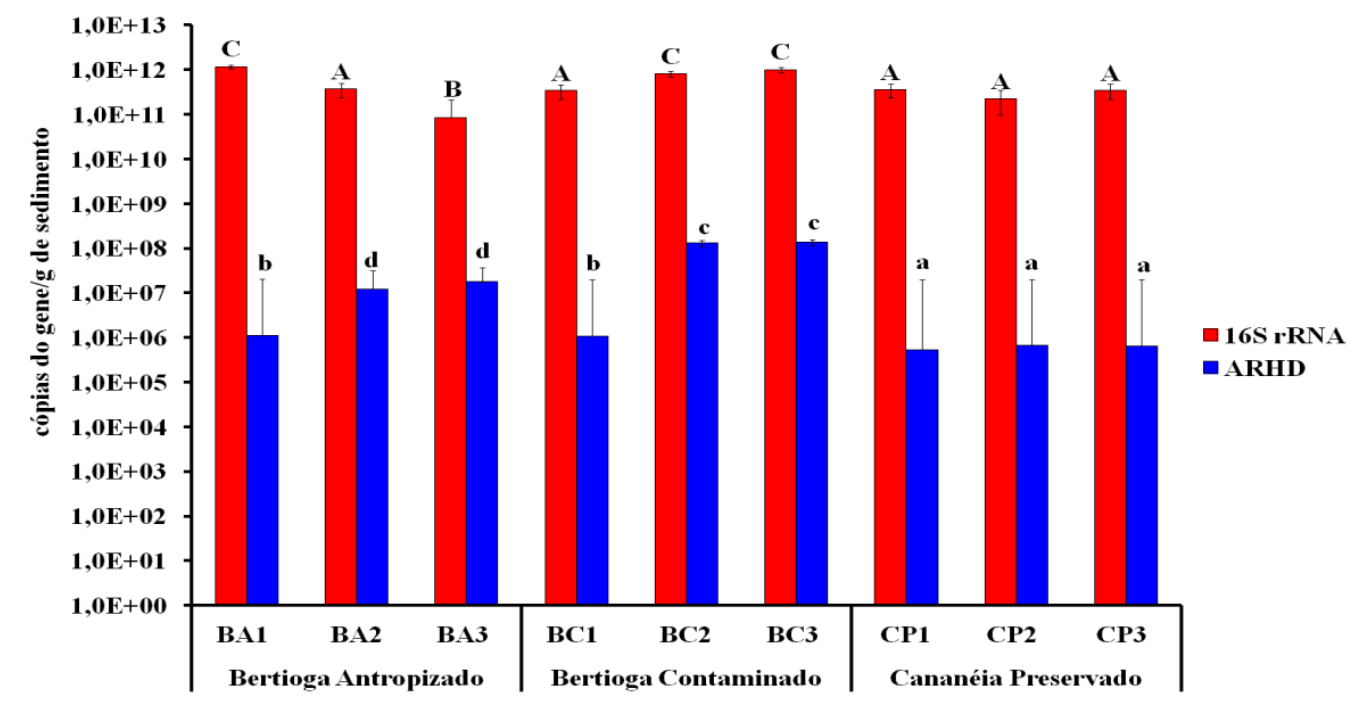

(II)

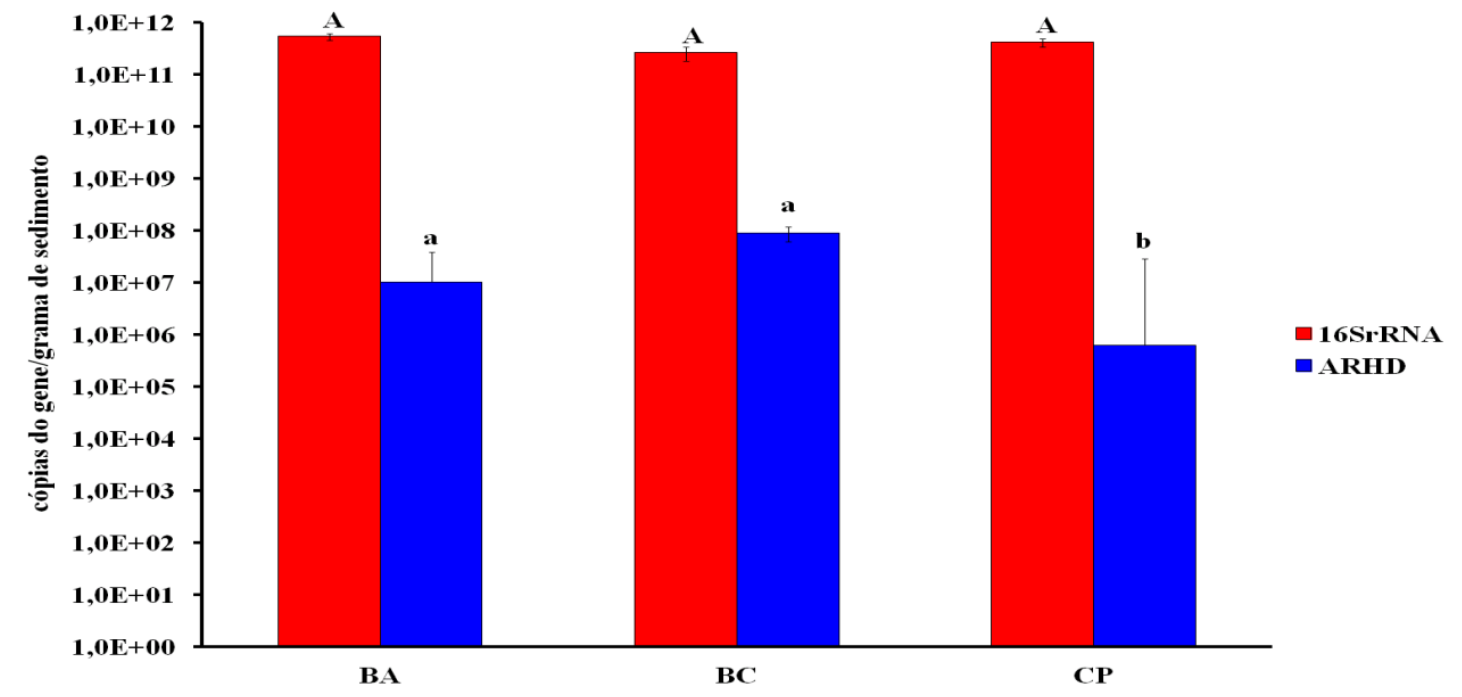

Os valores indicam a média \pm desvio padrão das triplicatas utilizadas, sendo que para cada uma delas, duas reações foram realizadas para evitar variações intrínsecas ao equipamento. As barras indicam o erro padrão da média gerado a partir das repetições ( $n=3$ em I e $n=9$ em II). Pontos amostrais que não compartilham mesma letra são significativamente diferentes entre si (ANOVA e teste de Turkey, $p \leq 0,05$ ). 


\subsection{Pirosequenciamento para o gene 16S rRNA}

O pirosequenciamento da região V4 do gene 16S rRNA foi realizado com o objetivo de verificar a diversidade nas comunidades microbianas das três áreas de estudo. Um total de 40.851 sequências válidas foram obtidas após remoção dos primers e tags e utilizando as ferramentas disponíveis no Ribosomal Database Project. A Tabela 11 apresenta uma descrição detalhada do número de sequências válidas e o comprimento médio das sequências obtidas por amostra e por manguezal.

Tabela 11. Descrição das amostras submetidas ao pirosequenciamento, número total e comprimento médio das sequências.

\begin{tabular}{cccc}
\hline Amostras & $\begin{array}{c}\text { Sequências válidas } \\
\text { por amostra }\end{array}$ & $\begin{array}{c}\text { Sequências válidas } \\
\text { por manguezal }\end{array}$ & $\begin{array}{c}\text { Comprimento médio } \\
\text { das sequências (pb) }\end{array}$ \\
\hline BA1 & 4.423 & & 331 \\
BA2 & 4.348 & 12.947 & 330 \\
BA3 & 4.176 & & 329 \\
BC1 & 4.184 & & 330 \\
BC2 & 4.996 & 13.950 & 330 \\
BC3 & 4.770 & & 330 \\
CP1 & 4.848 & & 330 \\
CP2 & 5.008 & 13.954 & 331 \\
CP3 & 4.098 & & 331 \\
\hline
\end{tabular}

A composição da comunidade bacteriana de cada manguezal foi caracterizada pela classificação taxonômica das sequências, que indicaram a presença de 27 filos, 63 classes, 78 ordens, 174 famílias e 527 gêneros bacterianos, sendo que um total de 4.109 sequências não puderam ser classificadas em um limiar de confiança de até $50 \%$ e não foram aqui consideradas.

A afiliação taxonômica permitiu observar diferenças entre as áreas estudadas e um panorama visual dos 25 principais gêneros encontrados em cada manguezal pode ser observado na Figura 29. No Manguezal de Bertioga Antropizado foram mais frequentes os gêneros Fusibacter, Sedimentibacter, Paracoccus, Lysinibacillus, Rhodobacter e Bacillus. No manguezal de Bertioga Contaminado os gêneros mais encontrados foram Paracoccus, Rhodobacter, Fusibacter, Celeribacter, Marinobacterium e Sedimentibacter. No ambiente 
preservado de Cananéia os gêneros mais prevalentes foram Gillisia, Lysinibacillus, Dehalogenimonas, Caldithrix, Fusibacter e Flavobacterium.

Figura 29. Ranking dos 25 gêneros mais abundantes obtidos para cada manguezal por meio da técnica de pirosequenciamento para o gene 16S rRNA.

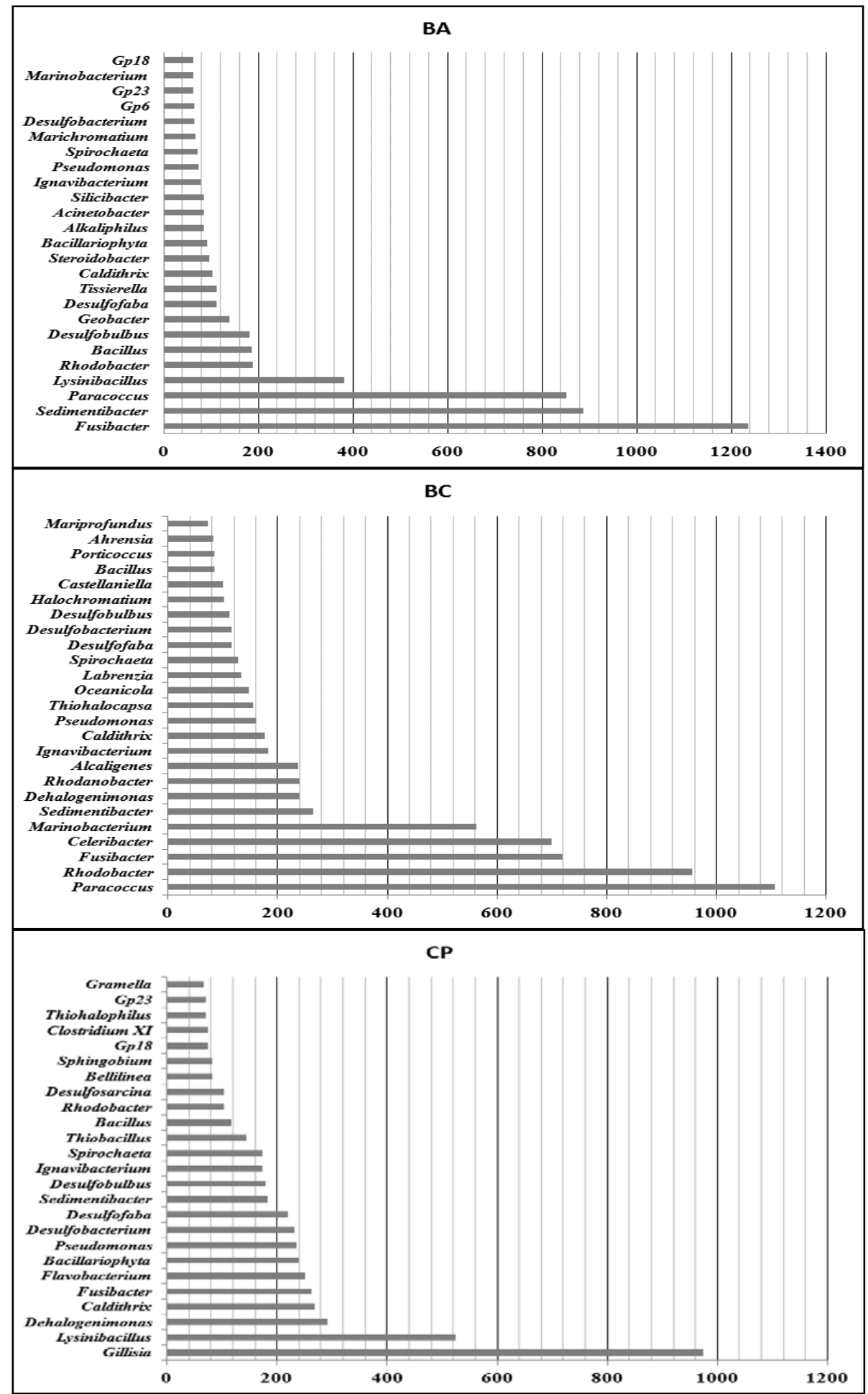

BA - Bertioga Antropizado, BC - Bertioga Contaminado e CP - Cananéia Preservado. A classificação das sequências foi realizada através da ferramenta Classifier (RDP). 
Considerando-se o total de sequências classificadas observa-se que os filos Proteobacteria (49,72\%) e Firmicutes (20,87\%) foram os que apresentaram as maiores frequências relativas, seguidos por Bacteroidetes (5,10\%), Chloroflexi (4,86\%), Acidobacteria (2,20\%), Deferribacteres (1,34\%) e Chlorobi (1,08\%). Os demais grupos apresentaram frequência inferior a 1\%. O Filo Proteobacteria representou 68,57\% das sequências obtidas em BC, 52,71\% das sequências de BA e 43,80\% das sequências de CP enquanto Firmicutes representou 32,21\% de BA, 21,0\% de CP e 16,94\% de BC como pode ser observado na Figura 30. A frequência de cada filo observada por ponto amostral consta na Figura 31-A e as principais classes pertencentes aos filos Proteobacteria e Firmicutes observadas por ponto amostral podem ser observadas na Figura 31-B e C. Em nosso trabalho, vamos dar ênfase na discussão destes grupos por representarem a maior porcentagem dos dados e por refletirem as maiores diferenças encontrada entre os ambientes estudados.

O filo Proteobacteria corresponde ao maior grupo bacteriano, de morfologia e metabolismo muito diversificado, incluindo micro-organismos fototróficos, heterotróficos e quimiolitotróficos (ETTEMA et al., 2009). Devido à elevada diversidade fisiológica este é o filo predominante em sistemas que possuam uma grande variedade de condições ambientais (KAZAKOV et al., 2009). A predominância do filo Proteobacteria em nosso estudo condiz com os resultados apresentados na literatura para amostras de manguezais, reportadas em trabalhos anteriores que empregaram técnicas moleculares (ANDREOTE et al., 2012; CASTINE et al., 2009; CURY, 2006; DIAS et al., 2010; LIANG et al., 2007; SANTOS et al., 2011b).

Em nosso estudo encontramos representantes das cinco classes de Proteobacteria, destacando-se Alphaproteobacteria (42,09\%), Gammaproteobacteria (26,88\%), Deltaproteobacteria (22,86\%) e Betaproteobacteria (7,59\%). No entanto, a análise dentro de cada manguezal apresentou diferenças quanto à frequência destas classes, como pode ser observado na Figura 31-B.

Se a análise é realizada levando em consideração o total de sequências de cada manguezal, observa-se que no manguezal de Bertioga Antropizado as classes mais abundantes foram: Alphaproteobacteria (44,82\%), Deltaproteobacteria (24,51\%), Gammaproteobacteria (24,47\%) e Betaproteobacteria (6,07\%). Em Bertioga Contaminado tivemos: Alphaproteobacteria (51,73\%), Gammaproteobacteria (26,12\%), Deltaproteobacteria (13,11\%) e Betaproteobacteria (8,16\%). Já em Cananéia a classe Deltaproteobacteria foi a mais frequente (37,52\%), seguida de Gammaproteobacteria (31,05\%), Alphaproteobacteria (22,33\%) e Betaproteobacteria (8,47\%). 
Figura 30. Frequência relativa dos diferentes táxons de Bacteria, obtidos por pirosequenciamento do gene 16S rRNA para cada manguezal analisado, com base na afiliação filogenética do RDP.
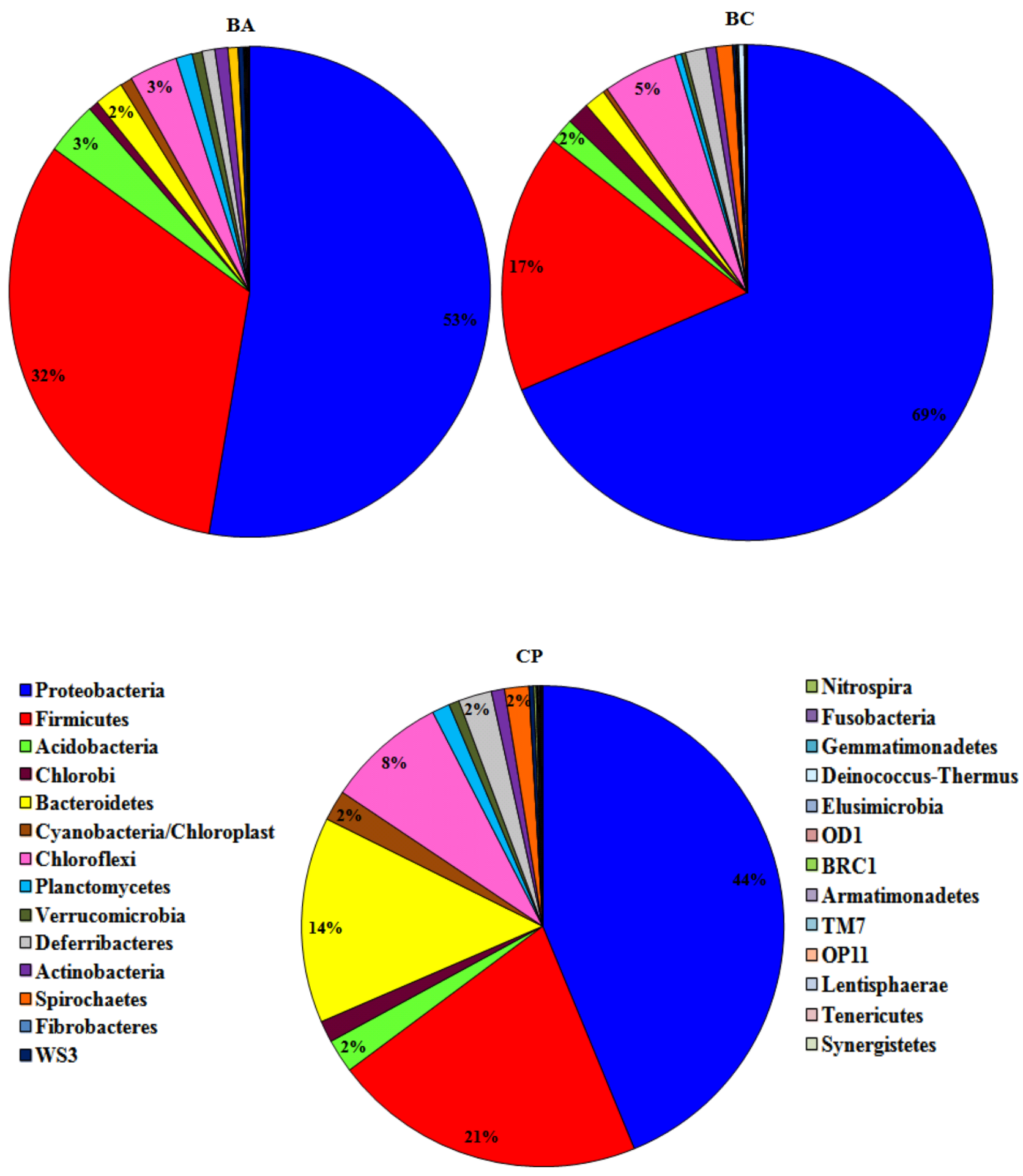

BA - Bertioga Antropizado, BC - Bertioga Contaminado e CP - Cananéia Preservado. 
Figura 31. Frequência relativa dos diferentes táxons de Bacteria, obtidos por pirosequenciamento do gene $16 \mathrm{~S}$ rRNA para cada ponto amostral, com base na afiliação filogenética do RDP.

A

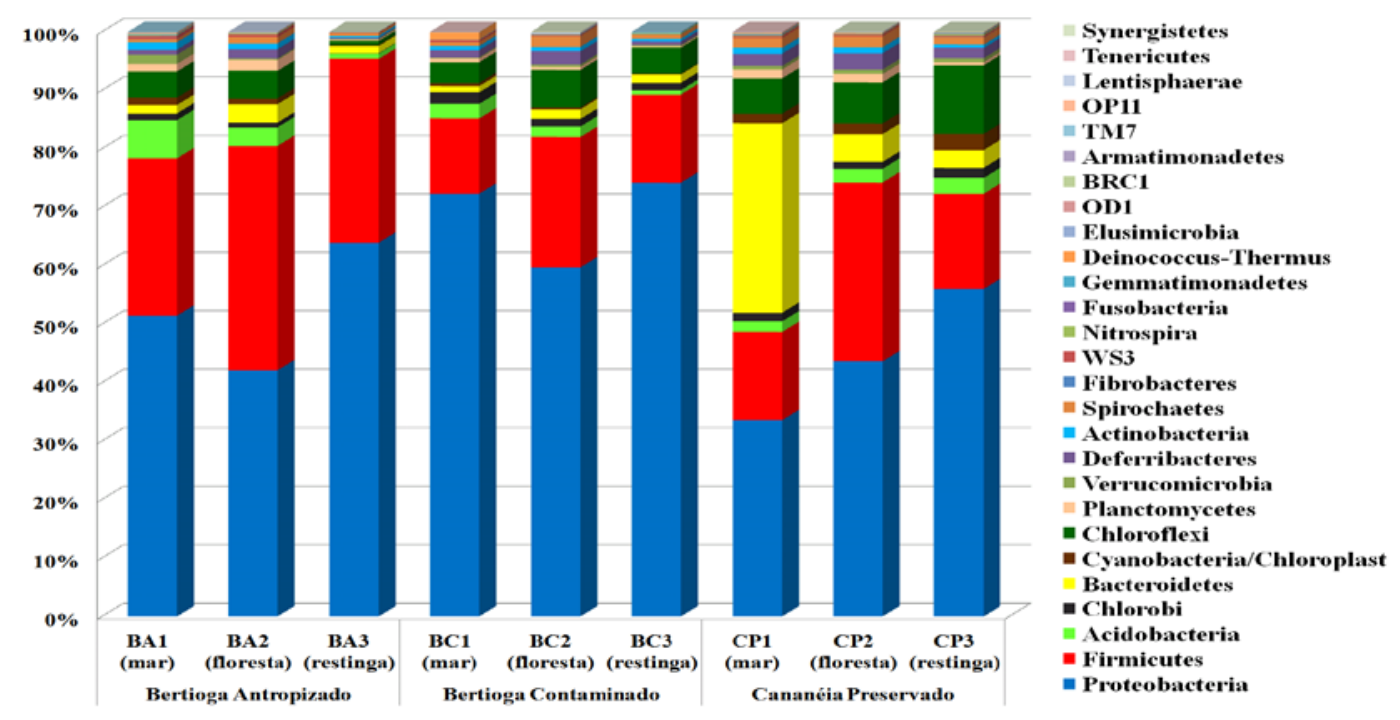

B

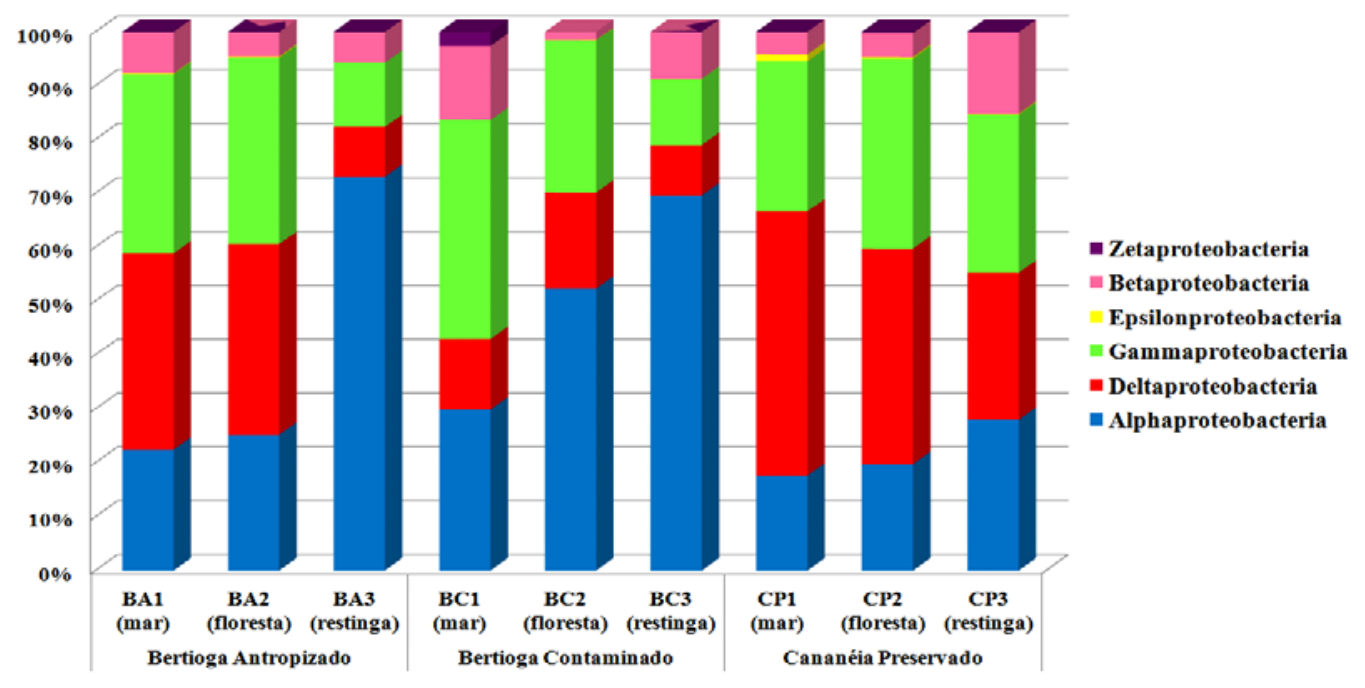

C

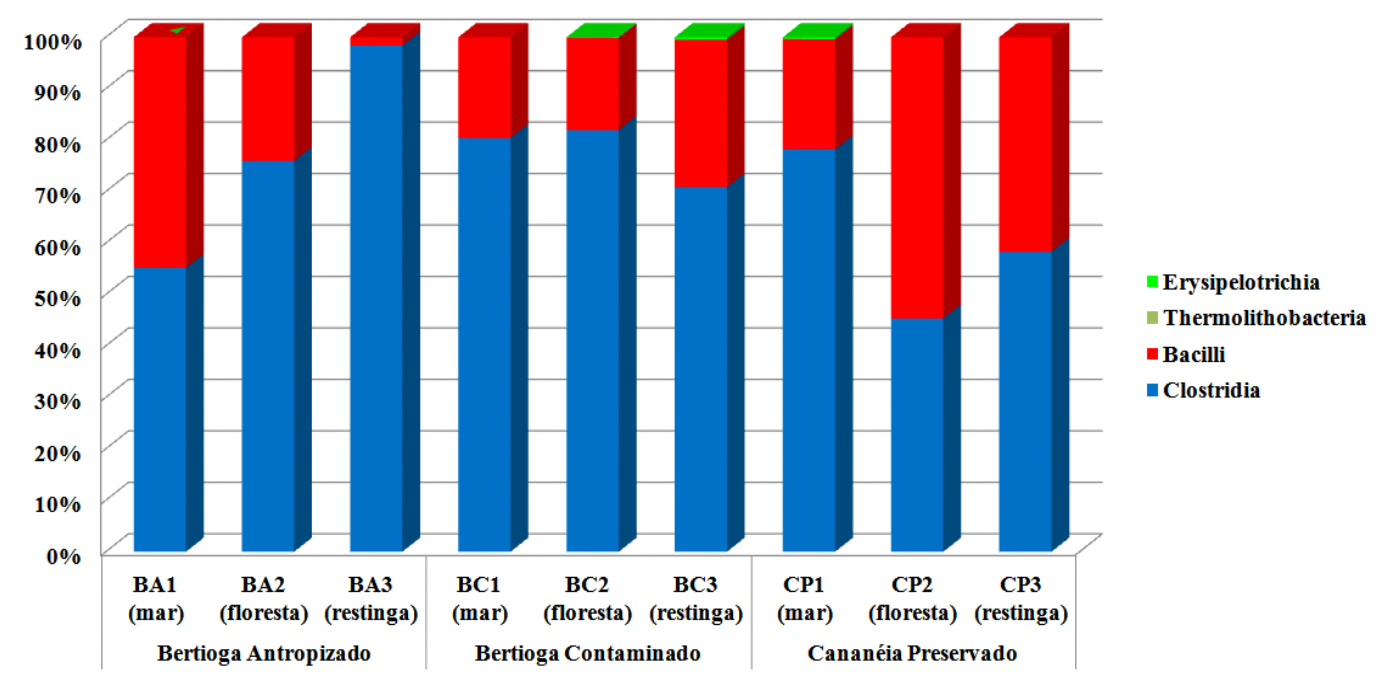

A - Filos, B - Classes de Proteobacteria e C - Classes de Firmicutes. 
Quando analisamos os resultados por ponto amostral, verifica-se que dos nove pontos amostrados a Classe Deltaproteobacteria foi mais frequente em BA1 (36,42\%), BA2 (35,35\%), CP1 (49,06\%) e CP2 (39,98\%). Em seguida vem a classe Alphaproteobacteria com as maiores porcentagem de frequência em BA3 (73,13\%), BC2 (52,34\%) e BC3 (69,62\%). Por último aparece a classe Gammaproteobacteria que apresentou maior frequência nos pontos BC1 (40,65\%) е CP3 (29,35\%).

De forma geral a classe Gammaproteobacteria é a mais reportada em ambientes de manguezais. Andreote et al. (2012) realizaram análise metagenômica para quatro amostras provenientes dos manguezais de Bertioga e Cananéia. Estes autores verificaram que as classes mais frequentes foram Gammaproteobacteria (32,6 a 42,6\%) seguida de Deltaproteobacteria (29,5 a 40,0\%), Alphaproteobacteria (7,5\% a 18,6\%), Betaproteobacteria (2,2 a 9,3\%) е Epsilonproteobacteria (2,3 a 20\%). Uma grande contribuição deste trabalho é a Análise de Componentes Principais realizada com os dados de metagenoma que colocam o manguezal como um ambiente peculiar apresentando a co-ocorrência de micro-organismos encontrados tanto em solos quanto em oceanos. Da mesma forma o trabalho associa a ocorrência do grupo Alphaproteobacteria a amostras de oceanos, Actinobacteria e Gammaproteobacteria são associadas ao grupo de sequencias de água de manguezais enquanto que Delta e Epsilonproteobacteria foram associados aos sedimentos de manguezais.

Em um estudo conduzido por Dias et al. (2010) foram analisadas bibliotecas de clones para determinar a diversidade de bactérias em cinco pontos amostrais de Cananéia. Os resultados obtidos por esses autores também diferem dos demais e revelam uma dominância dos filos Alphaproteobacteria (40,36\%), Gammaproteobacteria (19,28\%) e Acidobacteria (27,71\%) neste manguezal.

Com relação à variação observada no que se refere à frequência das classes de Proteobacteria em nosso estudo comparado aos demais, o que se pode inferir, é que alguns fatores podem influenciar no resultado obtido, como: (a) o ponto amostral e a profundidade do sedimento analisado, devido aos diferentes micro-habitats existentes dentro de um ecossistema de manguezal; (b) o tipo de vegetação presente no ambiente; (c) o estágio de preservação ou contaminação do ambiente analisado; e até mesmo (b) o conjunto de primers utilizados na reação de PCR, que pode ser mais específico para um determinado grupo. Tais suposições podem ser confirmadas ao analisar o trabalho conduzido por Cleary et al. (2012), que utilizaram a técnica de DGGE associada ao pirosequenciamento para demonstrar que os diferentes micro-habitats dentro de um manguezal apresentam diferenças significativas com relação à composição de Bacteria, Alphaproteobacteria e Betaproteobacteria. Em nosso 
estudo analisamos três manguezais com diferentes históricos de preservação e dentro de cada ambiente ainda foram selecionados três diferentes micro-habitas, o que torna difícil uma comparação mais aprofundada com os demais trabalhos.

Em nossos resultados, com relação à classe Alphaproteobacteria (Figura 32-A), observou-se uma parcela significativa da ordem Rhodobacterales (77,29\%), especialmente dos gêneros Paracoccus (48,64\%) e Rhodobacter (42,90\%) na amostra BC3 de Bertioga Contaminado. Na amostra BA3 o gênero Paracoccus representou 63,0\% das sequências encontradas. Comparando-se esses resultados com a amostra do ambiente preservado, verifica-se que o gênero Paracoccus representa apenas 9,74\% e Rhodobacter 20,19\% das sequências obtidas neste ambiente.

O gênero Paracoccus é composto de micro-organismos oxidantes de hidrogênio, quimiolitotróficos facultativos, apresentando diversas capacidades de degradação, potencial industrial e aplicações ambientais, especialmente para biorremediação (LI et al., 2010; LIN et al., 2010; SIDDAVATTAM et al., 2011). Esses micro-organismos têm sido isolados de solo contaminado (QIAO et al., 2010), ambiente marinho (HEAD et al., 2006) e tratamento de águas residuais (LI et al., 2010). São extremófilos, capazes de sobreviver em condições de aerobiose ou anaerobiose e se destacam por sua habilidade de redução do nitrato e possível origem ancestral da mitocôndria eucariótica, segundo a teoria da endo-simbiose (JOHN et al., 1975; LI et al., 2011).

O gênero Rhodobacter pertence ao grupo de bactérias púrpuras não sulfurosas, fototróficas, frequentemente encontradas em ambientes de água doce e marinho e inclui espécies que possuem uma extensiva variedade de capacidades metabólicas. A espécie Rhodobacter sphaeroides é o organismo foto-heterotrófico mais estudado e teve seu genoma sequenciado devido a suas características de complexidade genética (MERCER et al., 2012; PANDEY et al., 2012; PORTER et al., 2011).

Membros da classe Betaproteobacteria (Figura 32-B) foram observados em todos os pontos amostrais e verificou-se um predomínio das ordens Burkholderiales (67,63\%), Rhodocyclales $(14,40 \%)$ e Hydrogenophilales $(13,81 \%)$. Dentro dessas ordens os gêneros mais observados foram Alcaligenes (29,23\%), Thiobacillus (18,84\%), Castellaniella (12,22\%) e Georgfuschia (6,21\%). O gênero Alcaligenes apresentou maior frequência relativa nos pontos BA3 (41,32\%) e BC1 (70,96\%). O gênero Thiobacillus foi mais abundante em Cananéia onde sua frequência variou de 52,35\% (CP3) a 78,57\% (CP2). O gênero Castellaniella apresentou maior frequência em BC2 (42,86\%), BC1 (22,46\%) e BA3 
(14,88\%). Já o gênero Georgfuschia representou 25\% das sequências de Betaproteobacteria obtidas no ponto BC3.

A literatura confirma que todos os gêneros de Betaproteobacteria encontrados com maior frequência nos manguezais contaminado e antropizado já foram associados a processos de biodegradação de hidrocarbonetos aromáticos. Quanto aos membros da ordem Burkholderiales, micro-organismos do gênero Alcaligenes já foram associados a produção de biosurfactantes e biorremediação em áreas contaminadas com petróleo (BHARALI et al., 2011; TOLEDO et al., 2008) e o gênero Castellaniella foi inicialmente caracterizado por acomodar espécies anaeróbias e denitrificantes, sendo que a espécie Castallaniella daejeonensis foi isolada de amostras de solo contaminado com óleo (KIM et al., 2009; LEE et al., 2010; SPAIN et al., 2007). Quanto aos membros da ordem Rhodocyclales, a espécie Georgfuchsia tolurica é representada por micro-organismos anaeróbios estritos e foi descrita por realizar biodegradação de compostos aromáticos (WEELINK et al., 2009).

O gênero Thiobacillus pertence à ordem Hydrogenophilales e apresentou uma elevada frequência relativa no manguezal de Cananéia. Este gênero representa micro-organismos quimiolitotróficos com um repertório metabólico bastante associado à oxidação de enxofre e ferro, cujas reações geram grandes quantidades de ácido sulfúrico (BELLER et al., 2006; RAWLINGS et al., 1994).

A classe Deltaproteobacteria inclui bactérias mesofílicas redutoras de sulfato. Nesta classe a ordem Desulfobacterales (73,95\%) foi a mais frequentemente encontrada nas amostras de manguezal, com destaque para os gêneros Desulfobulbus (19,61\%), Desulfofaba (18,49\%) e Desulfobacterium (17,08\%). A ordem Myxococcales (9,55\%) foi a segunda mais frequente, com predomínio do gênero Geobacter cujas sequências corresponderam a 69,90\% das obtidas para a classe Deltaproteobacteria no ponto BA3 (Figura 32-C).

Considerando-se a classe Gammaproteobacteria (Figura 32-D) as ordens Chromatiales (22,79\%), Pseudomonadales (17,40\%) e Alteromonadales (16,37\%) foram as mais frequentes. Na ordem Chromatiales o gênero que apresentou maior destaque foi Thiohalocapsa, que representou 21,97\% das sequências do ponto BC2. Na ordem Pseudomonadales tivemos o gênero Pseudomonas representando 32,37\% de BC3 e 52,57\% de CP3. Quanto à ordem Alteromonadales o gênero com maior abundância foi Marinobacterium, que representou 47,29\% de BC1 e 24,43\% de BC2.

A ordem Chromatiales engloba bactérias fototróficas púrpuras de enxofre que participam da oxidação de sulfetos e tiossulfetos. Em nosso estudo esta ordem apresentou 
maiores frequências nos pontos amostrais BC2 e BC3 cujas concentrações de HPAs também foram as mais elevadas.

Em um estudo com microcosmos conduzido por Santos et al. (2011b) foi simulado um derramamento de óleo em amostras provenientes um manguezal preservado da Restinga da Marambaia. Os resultados de pirosequenciamento para o gene 16S rRNA mostraram que a ordem Chromatiales e o gênero Haliea reduziram com a exposição ao óleo e foram propostos como micro-organismos sensíveis à contaminação, enquanto o gênero Marinobacterium da ordem Alteromonadales aumentou sua prevalência de 1\% para 45\% na presença do óleo. O trabalho aqui apresentado e o trabalho de Santos e colaboradores concordam no aumento do gênero Marinobacterium no ambiente contaminado, que em nosso caso representou 25\% das sequências de Gammaproteobacteria no ponto BC2. Mas em nossos resultados o gênero Haliea não apresentou grandes alterações na comparação entre os ambientes. Possíveis explicações para tal diferença podem ser devido a: (1) profundidade das amostras de sedimento, que em nosso estudo foi de $0-10 \mathrm{~cm}$ enquanto que no trabalho de Santos as amostras foram coletadas a $20 \mathrm{~cm}$ de profundidade; (2) o período transcorrido desde a contaminação com o óleo até a análise, que em nosso trabalho foi de 29 anos (contaminação crônica) enquanto que no estudo de Santos foi de 66 dias.

Com relação à ordem Pseudomonadales, o gênero Pseudomonas já foi mencionado em nosso trabalho relacionado como hospedeiro do gene $\alpha$-ARHD e também foi isolado no processo de enriquecimento com bifenilo. Esse microrganiso é ubíquio com um alto grau de adaptabilidade genética e fisiológica. Membros deste gênero são encontrados em grande número em em diferentes ambientes naturais (JIMÉNEZ et al., 2004). É um micro-organismo dominante entre os gêneros bacterianos envolvidos em processos funcionais de mineralização de hidrocarbonetos no solo (FURUKAWA \& FUJIHARA, 2008; FURUKAWA \& MIYAZAKI, 1986; JACQUES et al., 2005; KIMBARA et al., 1989; MA et al., 2006a) e em ambiente marinho (HEAD et al., 2006). Em nosso estudo este gênero apresentou maior frequência nos pontos amostrais relacionados à restinga (P3) quando comparados às florestas de manguezal (P2) e aos pontos próximos ao curso d’água (P1). Um fator importante a se considerar é que esse gênero bacteriano representava 51,57\% das sequências relacionadas a Gammaproteobacteria na amostra CP3 de Cananéia, no entanto, não foi possível obter isolados a partir do enriquecimento com bifenilo neste ponto amostral, demonstrando a ausência da capacidade metabólica das espécies ali presentes. 
Figura 32. Frequência relativa dos gêneros encontrados em cada classe do Filo Proteobacteria nas amostras analisadas.
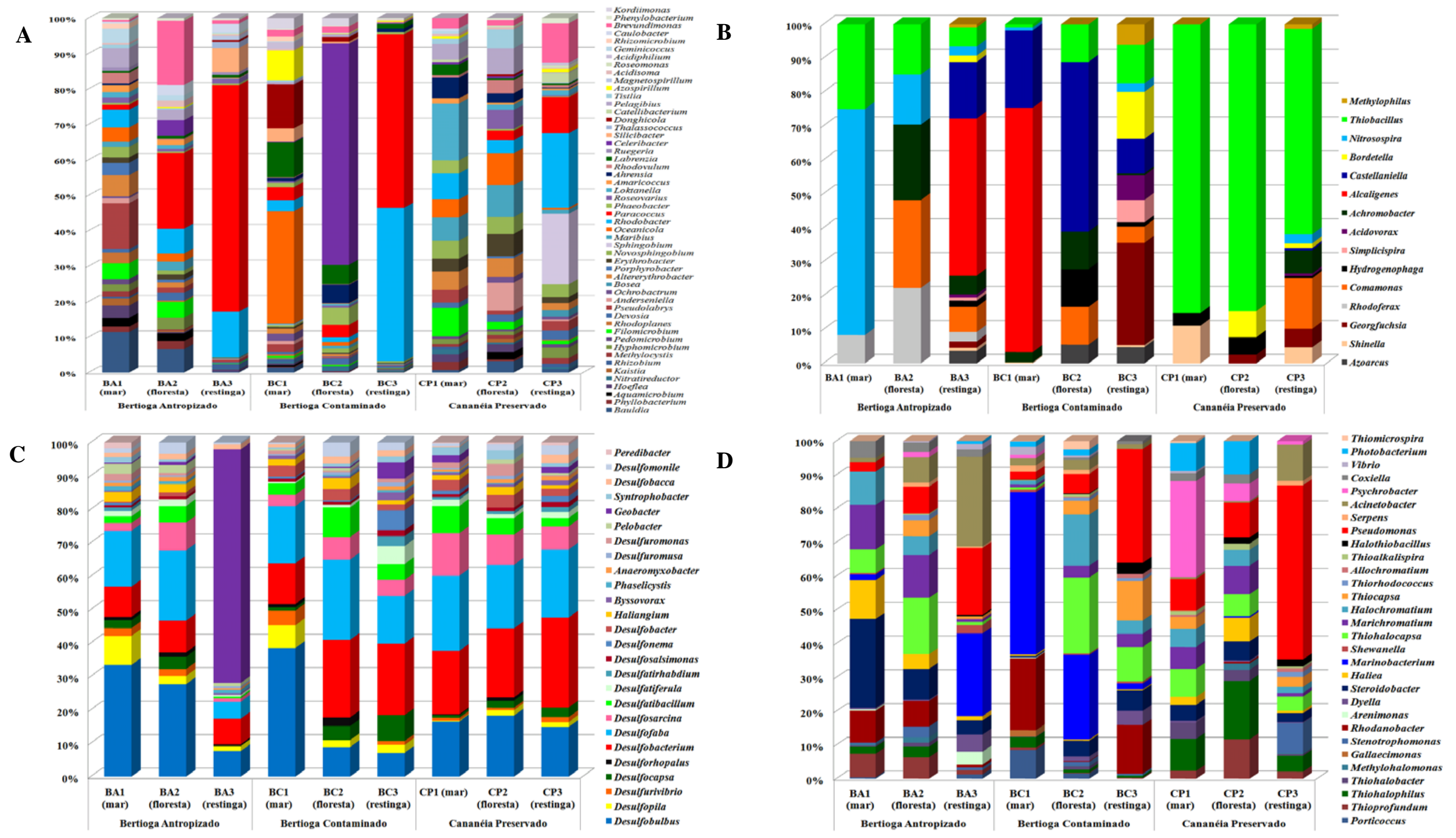
O filo Firmicutes foi o segundo maior grupo detectado através da afiliação filogenética das sequências analisadas, correspondendo a 32,0\% de Bertioga Antropizado, 17,0\% de Bertioga Contaminado e 21,0\% das sequências obtidas a partir das amostras de Cananéia, conforme apresentado nas Figuras 30 e 31-C. Este filo é composto por bactérias aeróbias e anaeróbias Gram-positivas que apresentam grande importância no ciclo do enxofre (JANSSEN, 2006). Em nosso estudo este filo foi representado principalmente pelas classes Clostridia (71,57\%) e Bacilli (28,35\%). Em Bertioga Antropizado essas classes representaram 77,95\% (Clostridia) e 22,05\% (Bacilli) das sequências de Firmicutes e em Bertioga Contaminado 78,09\% (Clostridia) e 21,71\% (Bacilli). Em Cananéia a porcentagem relativa foi de 56,02\% para Clostridia e 43,89\% para Bacilli.

Clostridia é uma classe de bactérias sulfito-redutoras que se caracteriza por representar bacilos estritamente anaeróbios e alguns membros desta classe já foram associados à biodegradação de tolueno pelo uso da técnica de Stable Isotope Probing, (WINDERL et al., 2010). Em nosso estudo uma diferenciação importante na classe foi observada para o gênero Fusibacter, que representou 76,75\% das amostras de BA3, 51,21\% de BC2 enquanto em Cananéia a maior porcentagem foi observada para o ponto CP2 (28,08\%), como pode ser observado na Figura 33-A. O gênero Fusibacter é conhecido por constituir de microorganismos halotolerantes, capazes de reduzir tiosulfato a sulfito e já foram isolados de águas residuais e reatores de fábricas de óleo (BEN HANIA et al., 2012; MERCER et al., 2012; RAVOT et al., 1999).

A versatilidade metabólica do gênero Bacillus já foi discutida neste trabalho por se tratar de um gênero bacteriano bastante estudado em processos de biorremediação (ALCARAZ et al., 2010; GOUD et al., 2012; VOLKOVA et al., 1989) e por apresentar o maior número de representantes em nossos enriquecimentos. Lysinibacillus foi o gênero que apresentou maior frequência nas amostras de Cananéia, representando 41,17\% de CP2, 28,36\% de CP3 e 23,58\% de CP1. Micro-organismos do gênero Lysinibacillus já foram descritos como patógenos de insetos e camarões (BERRY, 2012), biodegradadores de inseticidas (LIANG, B. et al., 2009; YAO et al., 2011), compostos fenólicos (YAO et al., 2011) e de dibenzotiofenos (BAHUGUNA et al., 2011). É importante mencionar que esse gênero microbiano foi o único isolado nos três manguezais a partir do enriquecimento com bifenilo, sendo que para os enriquecimentos a partir das amostras de sedimento de Cananéia esta foi a única espécie isolada.

Apesar de o filo Actinobacteria não apresentar uma frequência elevada em nosso estudo, uma diferença importante entre os manguezais foi observada neste grupo com relação 
ao gênero Rhodococcus, cuja frequência foi inferior a 1\% nos pontos amostrais da área preservada, mas variou de 26,1\% (BC2) a 44,4\% (BC3) nas amostras do manguezal com histórico de contaminação com petróleo e de 17,0\% (BA1) a 41,7\% (BA2) em Bertioga Antropizado, como pode ser visualizado na Figura 33-B. Tais frequências podem ser explicadas pelo fato de que o gênero Rhodococcus é bastante diverso e apresenta a habilidade de degradar um grande número de compostos orgânicos, incluindo alguns compostos de elevada toxicidade e recalcitrância (LARKIN et al., 2005). Estes micro-organismos parecem ter adotado uma estratégia de hiper-combinação associada à um grande genoma. Notavelmente eles abrigam um grande número de plasmídeos lineares que contribuem para sua diversidade catabólica e eficiência e são candidatos ideais para biorremediação de áreas contaminadas (LARKIN et al., 2005; MARTÍNKOVÁ et al., 2009; PIZZUL, L et al., 2007).

Figura 33. Frequência relativa dos principais gêneros encontrados nos Filos: Firmicutes (A) e Actinobacteria (B).

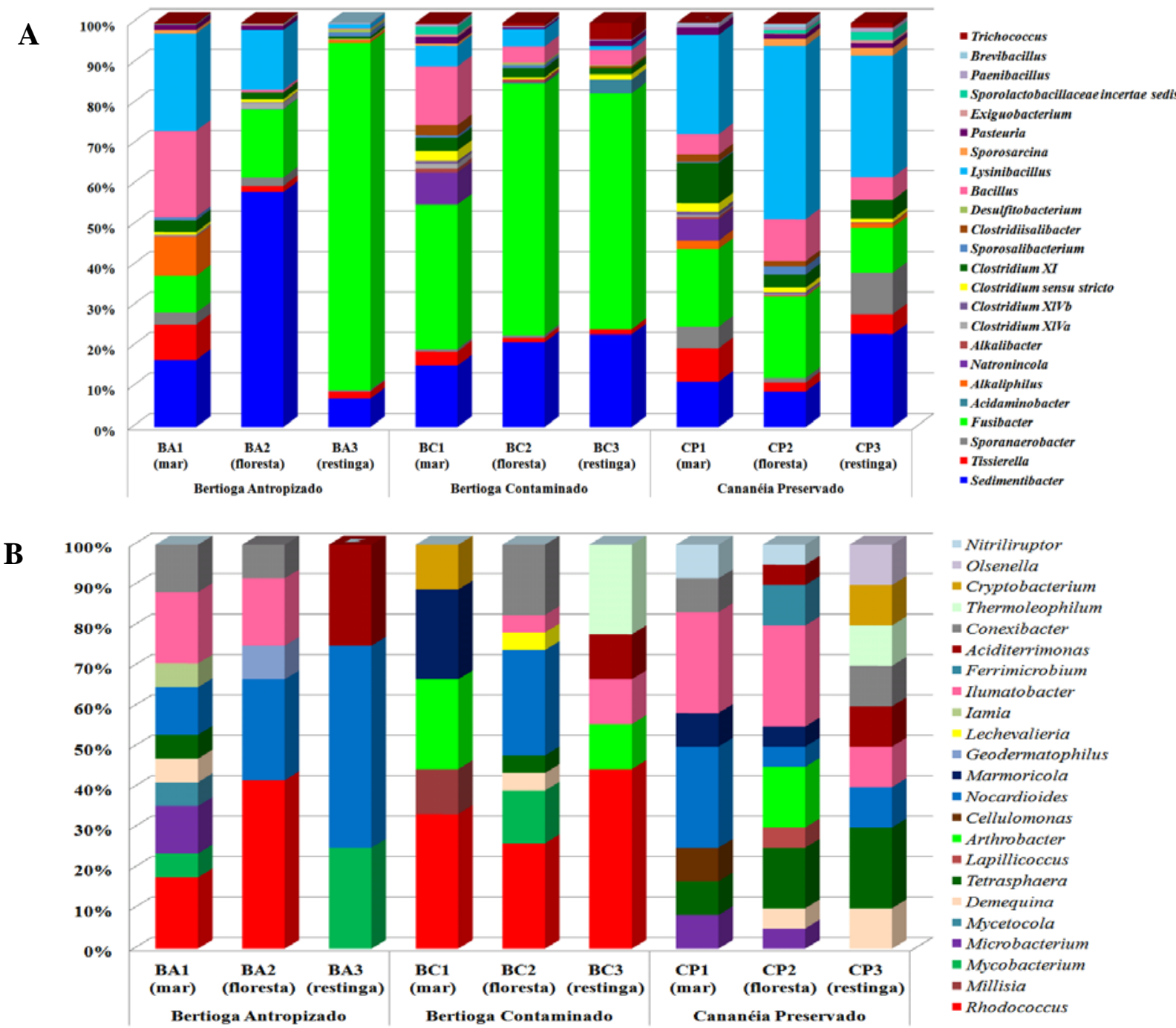


Em estudos de ecologia microbiana, o uso de técnicas de biologia molecular tem aumentado as possibilidades do reconhecimento espacial e temporal dos padrões das comunidades microbiológicas. É de conhecimento geral que os métodos baseados na análise das sequências do 16S rRNA para estudos de diversidade de bactérias apresentam suas limitações, como o viés da PCR em favor de grupos mais dominantes, a variabilidade genética do fragmento do gene analisado e o número de sequências analisadas em relação à riqueza de espécies (CURY, 2006). No entanto, como pudemos observar com os resultados aqui obtidos, a estratégia molecular foi capaz de fornecer uma série de informações que outros métodos, como aqueles baseados em cultivo, não forneceriam.

Os manguezais aqui estudados também foram avaliados quanto ao seu agrupamento hierárquico a partir de uma matriz construída com a abundância dos filos em cada ponto amostral. Um dendograma de distância euclidiana foi gerado representado por perfis de intensidade de cores, como pode ser observado na Figura 34.

Nesta análise realizada unicamente com os dados de abundância de filos, observa-se que as amostras provenientes dos manguezais BA e BC formaram dois grupos distintos enquanto que as amostras de Cananéia apresentaram-se distribuídas. Pode-se ainda inferir, sobre este resultado, que considerando-se as amostras dos manguezais BA e BC os pontos P1 e P3 mostraram-se mais próximos enquanto P2 diferenciou-se destes. Comparando os resultados deste agrupamento com aqueles obtidos na PCA com os dados físico-químicos (Figura 16) observa-se que em ambos as amostras BA1, BA2 e BA3, assim como BC1, BC2 e BC3 mantiveram-se unidas, enquanto as amostras de CP apresentaram-se mais distantes entre si.

A amostra CP1 também foi aquela que se mostrou mais distante de todas as demais na análise de agrupamento, estando aqui associada ao filo Bacteroidetes. O ponto amostral CP2 mostrou-se próximo ao agrupamento do manguezal BA, estando mais associado à amostra BA2 enquanto que a amostra CP3 mostrou-se agrupada ao manguezal BC, especialmente à amostra BC2. De forma semelhante ao observado para as amostras, verifica-se que o filo Proteobacteria foi aquele que mais se distanciou dos demais, estando mais relacionado às amostras do manguezal de Bertioga Contaminado.

É importante, todavia, ressaltar que os aspectos abióticos de um ambiente possuem íntima relação com a estrutura e função da biota que o ocupa. Fatores como pH, quantidade de matéria orgância, concentração de sais e nutrientes, vegetação local e atividades antrópicas podem influenciar nas atividades dos micro-organismos e nas estruturas das comunidades microbianas dos solos (SINGH et al., 2006). 
Figura 34. Mapa de cores com análise de agrupamento das amostras baseado na abundância de filos encontrada.

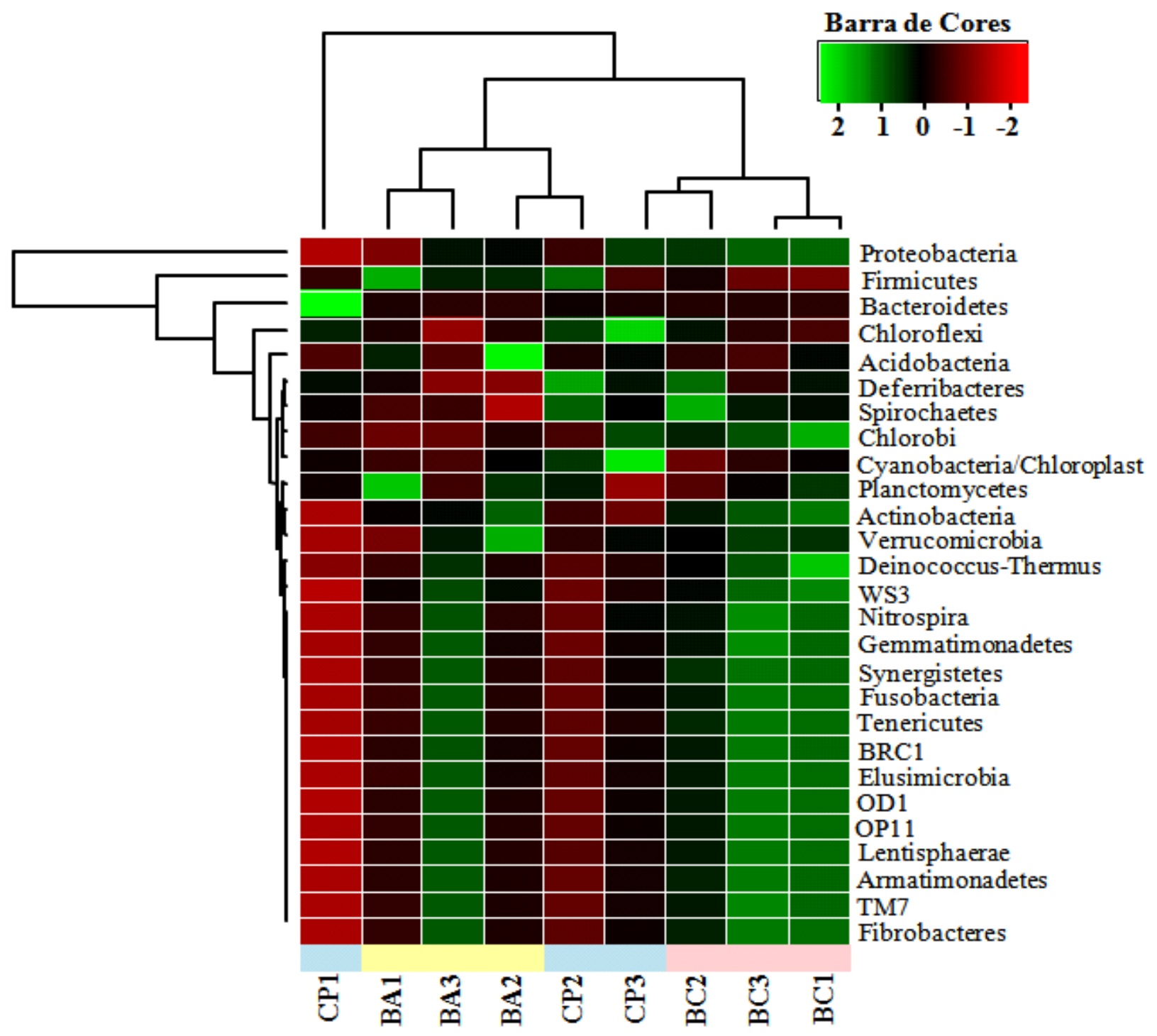

As colunas representam as amostras e as linhas representam os filos.

Em nosso estudo, a variação na comunidade microbiana, observada a partir do pirosequenciamento para o gene 16S rRNA, foi também correlacionada, pela Análise de Componentes Principais (PCA), com os dados físico-químicos e concentrações de HPAs para cada ponto amostral analisado. Os gráficos resultantes desta correlação podem ser visualizados na Figura 35-A-B-C, mas de forma geral a PCA mostrou que a estrutura das comunidades variou em função do manguezal analisado, sendo que, diferente dos resultados de agrupamento, os pontos P1 (curso d’água) e P2 (floresta) foram mais próximos entre si e o ponto P3 (restinga) foi aquele que mostrou-se mais distantemente relacionado aos demais em todos os manguezais. 
Figura 35. Análise de Componentes Principais correlacionando os filos encontrados pelo pirosequenciamento do gene 16S rRNA, as características físico-químicas e concentrações de Hidrocarbonetos Policíclicos Aromáticos (HPAs) para cada amostra de sedimento analisada.
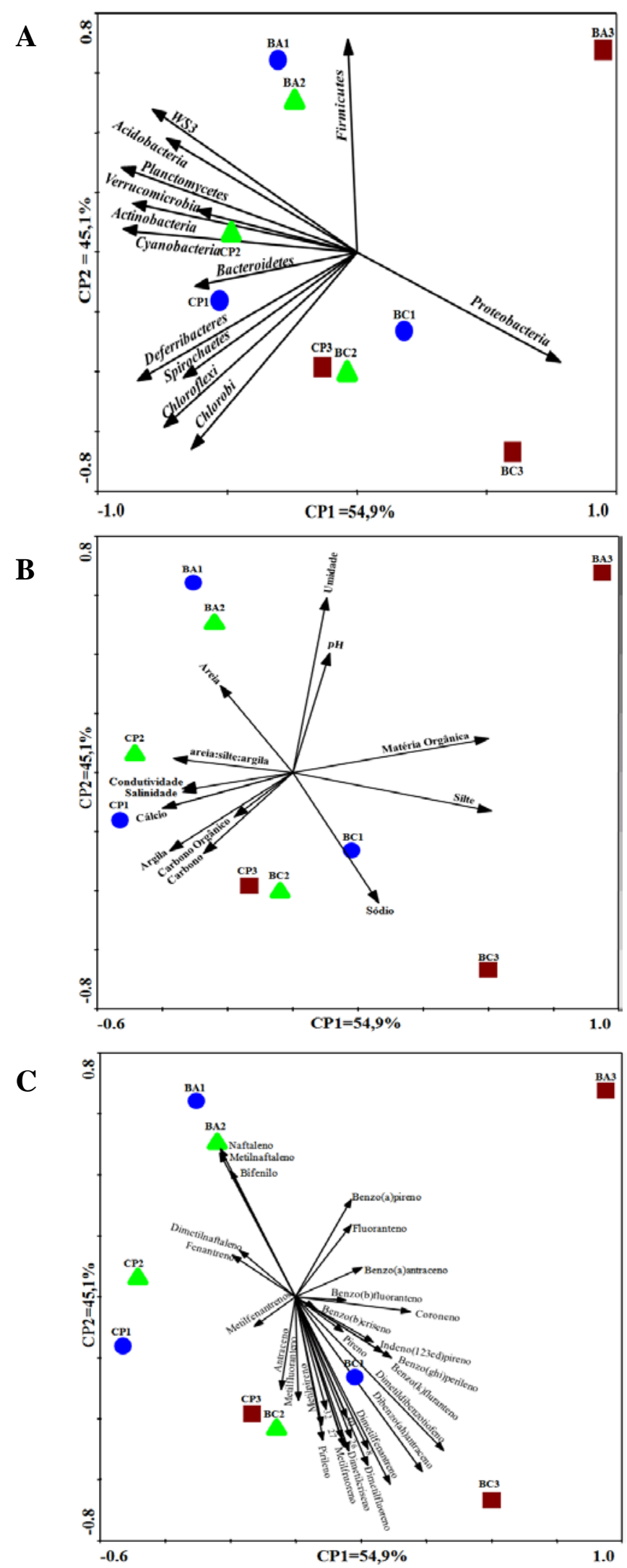

Os gráficos foram plotados considerandose as seguintes variáveis: (A) - Ponto Amostral x Filos; (B) - Ponto Amostral x Físico-químicos e (C) - Ponto Amostral x Hidrocarbonetos. 
Pela ordenação das amostras observa-se que os pontos BA1 e BA2 mostraram interação com o filo Firmicutes, com as porcentagem de areia e umidade e concentrações de naftaleno, metilnaftaleno e bifenilo. Os pontos BC1, BC2 e CP3 apresentaram maior correlação com os filos Proteobacteria e Chlorobi, com o sódio e concentrações de antraceno, dibenzo(a,h)antraceno e metilfluoranteno. Já os pontos CP1 e CP2 apresentaram interação com os filos Actinobaceria e Bacteroidetes, com a proporção areia:silte:argila, condutividade, porcentagens de salinidade e cálcio e com os hidrocarbonetos fenantreno, dimetilfenantreno e metilfenantreno. O ponto BC3 apresentou correlação com o filo Proteobacteria, com a porcentagem de sódio e com os hidrocarbonetos dimetildibenzotiofeno, dibenzo(a,h)antraceno e dimetilfenantreno.

Comparando-se a PCA realizada unicamente com os dados físico-químicos (Figura 16) com a PCA utilizando os fatores bióticos (filos) e abióticos (físico-químicos e hidrocarbonetos) aqui analisados (Figura 35-A-B-C), verifica-se que nesta última houve um distanceamento entre os manguezais BA e BC e uma aproximação do manguezal CP com o BC, diferente do que ocorria na primeira PCA. A amostra CP1 que apresentava-se totalmente distanciada de todas as demais na análise unicamente fisico-química e na análise de agrupamento (Figura 34), agora aproxima-se da amostra CP2, sendo que as amostras BA3 e BC3 foram aquelas se apresentaram deslocadas na segunda análise. Uma outra variação diz respeito às amostras $\mathrm{BC} 2$ e $\mathrm{CP} 3$, que da mesma forma que observado na análise de agrupamento, elas mantiveram uma proximidade nesta última PCA.

Da mesma forma que o realizado com as sequências das bibliotecas do gene $\alpha$-ARHD, o método de análise baseado na geração de OTUs foi realizado para analisar a frequência de distribuição das sequências do gene 16S rRNA através de uma matriz de distância. Esta estratégia possibilitou calcular os índices de riqueza e estimativas de diversidade das comunidades microbianas pela geração de grupos distintos em cada intervalo de cutoff da matriz de distância. A estimativa de rarefação das amostras foi calculada para os intervalos de cutoffs 0,$03 ; 0,05 ; 0,10$ e 0,20 com as sequências totais em cada manguezal (Tabela 12) e posteriormente a análise foi realizada considerando-se os pontos amostrais dentro de cada manguezal (Tabelas 13, 14 e 15). As curvas de rarefação foram construídas para verificar se as sequências do gene 16S rRNA obtidas representam a riqueza de organismos da comunidade, considerando as sequências totais em cada manguezal (Figura 36) e considerando os pontos amostrais dentro de cada manguezal (Figura 37).

Levando-se em consideração a análise geral, feita por manguezal (Tabela 12) é possível verificar que o manguezal de Cananéia foi aquele que apresentou o maior número de OTUs e 
os maiores índices de riqueza e estimativas de diversidade. Em contrapartida o manguezal de Bertioga Contaminado apresentou o menor número de OTUs e também os menores índices de riqueza e estimativas de diversidade.

As curvas de rarefação para as sequências nucleotídicas obtidas para o gene 16S rRNA (Figura 36) demonstraram que o esforço amostral não foi suficiente para cobrir a riqueza de espécies (cutoff de 0,03) em nenhum dos manguezais. Uma cobertura superior a 90\% só foi obtida a partir do cutoff de 0,05 no manguezal de BC indicando que a riqueza de gêneros foi contemplada neste manguezal, mas para os demais manguezais essa cobertura só foi alcançada a partir do cutoff de 0,10, contemplando apenas a riqueza de famílias e filos.

Posteriormente foi realizada uma análise dentro de cada manguezal, considerando agora os diferentes pontos amostrais. Foram calculadas igualmente as estimativas de rarefação de OTUs para os cutoffs 0,03; 0,05; 0,10 e 0,20 (Figura 37). Fica evidente nesta análise intramanguezal, que os pontos amostrais de Cananéia apresentam os maiores números de OTUs e os maiores índices de riqueza e estimativas de diversidade, quando comparados a todos os demais pontos dos outros manguezais. Outra observação importante diz respeito ao ponto amostral P3 (restinga), que apresentou os menores números de OTUs e índices de riqueza e estimativas de diversidade comparando-se aos pontos P1 (curso d'água) e P2 (floresta) dentro de todos os manguezais analisados, sugerindo que a comunidade que habita a área de manguezal próxima à restinga tenha um menor número de táxons quando comparada à floresta e área próxima ao curso d’água nestes manguezais.

As curvas de rarefação, considerando os diferentes pontos amostrais dentro de cada manguezal, demonstraram que o esforço amostral somente foi suficiente para cobrir a riqueza de filos (cutoff 0,20) nas amostras de Cananéia. Para as amostras de Bertioga Antropizado o esforço amostral cobriu a riqueza de gêneros (cutoff 0,05) no ponto BA3, mas somente a riqueza de filos (cutoff 0,20) foi contemplada nos pontos BA1 e BA2. Já para as amostras de Bertioga Contaminado a riqueza de famílias (cutoff 0,10 ) foi contemplada em todos os pontos analisados. 
Tabela 12. Número de OTUs e índices de alfa-diversidade estimados para as sequências obtidas por pirosequenciamento do gene 16S rRNA dos manguezais analisados.

\begin{tabular}{|c|c|c|c|c|c|c|c|c|}
\hline \multirow{2}{*}{ Biblioteca } & \multirow{2}{*}{$\mathbf{N}^{0}$ Seqs } & \multirow{2}{*}{ Cutoff } & \multirow{2}{*}{ OTUs } & \multicolumn{2}{|c|}{ Riqueza } & \multicolumn{2}{|c|}{ Diversidade } & \multirow{2}{*}{$\begin{array}{c}\text { Cobertura } \\
\%\end{array}$} \\
\hline & & & & Chao1 & ACE & Shannon & Simpson & \\
\hline \multirow{4}{*}{ BA } & \multirow{4}{*}{12.946} & 0,03 & 3.212 & 7.364 & 11.164 & 6,30 & 0,005 & 0,74 \\
\hline & & 0,05 & 2.524 & 5.060 & 7.608 & 5,97 & 0,006 & 0,80 \\
\hline & & 0,10 & 1.518 & 2.507 & 3.256 & 5,40 & 0,009 & 0,90 \\
\hline & & 0,20 & 464 & 567 & 554 & 4,35 & 0,018 & 0,98 \\
\hline \multirow{4}{*}{ BC } & \multirow{4}{*}{13.950} & 0,03 & 2.990 & 6.927 & 11.367 & 6,12 & 0,015 & 0,87 \\
\hline & & 0,05 & 2.374 & 5.033 & 7.988 & 5,86 & 0,016 & 0,90 \\
\hline & & 0,10 & 1.412 & 2.377 & 3.238 & 5,08 & 0,029 & 0,95 \\
\hline & & 0,20 & 460 & 539 & 552 & 4,04 & 0,077 & 0,99 \\
\hline \multirow{4}{*}{$\mathbf{C P}$} & \multirow{4}{*}{13.954} & 0,03 & 4.435 & 11.398 & 19.000 & 7,19 & 0,005 & 0,79 \\
\hline & & 0,05 & 3.526 & 8.346 & 14.266 & 6,79 & 0,006 & 0,84 \\
\hline & & 0,10 & 2.151 & 4.018 & 5.725 & 6,06 & 0,010 & 0,92 \\
\hline & & 0,20 & 667 & 826 & 842 & 4,99 & 0,017 & 0,99 \\
\hline
\end{tabular}

Tabela 13. Número de OTUs e índices de alfa-diversidade estimados para as sequências dos pontos amostrais do manguezal de Bertioga Antropizado obtidas através do pirosequenciamento do gene $16 \mathrm{~S}$ rRNA.

\begin{tabular}{|c|c|c|c|c|c|c|c|c|}
\hline \multirow{2}{*}{ Biblioteca } & \multirow{2}{*}{$N^{0}$ Seqs } & \multirow{2}{*}{ Cutoff } & \multirow{2}{*}{ OTUs } & \multicolumn{2}{|c|}{ Riqueza } & \multicolumn{2}{|c|}{ Diversidade } & \multirow{2}{*}{$\begin{array}{c}\text { Cobertura } \\
\%\end{array}$} \\
\hline & & & & Chao1 & ACE & Shannon & Simpson & \\
\hline \multirow{4}{*}{ BA1 } & \multirow{4}{*}{4.422} & 0,03 & 1.779 & 4.121 & 6.785 & 6,65 & 0,005 & 0,74 \\
\hline & & 0,05 & 1.444 & 3.099 & 4.837 & 6,35 & 0,006 & 0,80 \\
\hline & & 0,10 & 924 & 1.654 & 2.115 & 5,74 & 0,009 & 0,89 \\
\hline & & 0,20 & 361 & 486 & 461 & 4,68 & 0,018 & 0,98 \\
\hline \multirow{4}{*}{ BA2 } & \multirow{4}{*}{4.348} & 0,03 & 1.643 & 4.400 & 7.883 & 6,21 & 0,016 & 0,74 \\
\hline & & 0,05 & 1.363 & 3.146 & 5.114 & 5,96 & 0,017 & 0,80 \\
\hline & & 0,10 & 925 & 1.771 & 2.585 & 5,41 & 0,022 & 0,88 \\
\hline & & 0,20 & 359 & 508 & 471 & 4,49 & 0,034 & 0,97 \\
\hline \multirow{4}{*}{ BA3 } & \multirow{4}{*}{4.176} & 0,03 & 723 & 2.152 & 4.457 & 3,83 & 0,115 & 0,88 \\
\hline & & 0,05 & 620 & 1.516 & 2.942 & 3,66 & 0,120 & 0,90 \\
\hline & & 0,10 & 452 & 906 & 1.306 & 3,41 & 0,126 & 0,94 \\
\hline & & 0,20 & 201 & 287 & 274 & 2,65 & 0,217 & 0,98 \\
\hline
\end{tabular}


Tabela 14. Número de OTUs e índices de alfa-diversidade estimados para as sequências dos pontos amostrais do manguezal de Bertioga Contaminado obtidas através do pirosequenciamento do gene $16 \mathrm{~S}$ rRNA.

\begin{tabular}{|c|c|c|c|c|c|c|c|c|}
\hline \multirow{2}{*}{ Biblioteca } & \multirow{2}{*}{$\mathbf{N}^{0}$ Seqs } & \multirow{2}{*}{ Cutoff } & \multirow{2}{*}{ OTUs } & \multicolumn{2}{|c|}{ Riqueza } & \multicolumn{2}{|c|}{ Diversidade } & \multirow{2}{*}{$\begin{array}{c}\text { Cobertura } \\
\% \\
\end{array}$} \\
\hline & & & & Chao1 & ACE & Shannon & Simpson & \\
\hline \multirow{4}{*}{ BC1 } & \multirow{4}{*}{4.182} & 0,03 & 1.201 & 3.008 & 5.311 & 5,63 & 0,017 & 0,81 \\
\hline & & 0,05 & 1.022 & 2.394 & 3.818 & 5,44 & 0,018 & 0,85 \\
\hline & & 0,10 & 684 & 1.343 & 1.977 & 4,91 & 0,027 & 0,91 \\
\hline & & 0,20 & 299 & 404 & 417 & 4,17 & 0,040 & 0,98 \\
\hline \multirow{4}{*}{ BC2 } & \multirow{4}{*}{4.996} & 0,03 & 1.478 & 3.559 & 6.195 & 5,85 & 0,022 & 0,81 \\
\hline & & 0,05 & 1.234 & 2.740 & 4.329 & 5,64 & 0,023 & 0,85 \\
\hline & & 0,10 & 821 & 1.557 & 2.177 & 4,96 & 0,032 & 0,91 \\
\hline & & 0,20 & 337 & 417 & 432 & 4,09 & 0,057 & 0,98 \\
\hline \multirow{4}{*}{ BC3 } & \multirow{4}{*}{4.769} & 0,03 & 1.148 & 2.768 & 4.614 & 4,69 & 0,079 & 0,84 \\
\hline & & 0,05 & 966 & 2.221 & 3.479 & 4,50 & 0,083 & 0,87 \\
\hline & & 0,10 & 641 & 1.104 & 1.618 & 4,04 & 0,096 & 0,93 \\
\hline & & 0,20 & 293 & 385 & 404 & 3,19 & 0,196 & 0,98 \\
\hline
\end{tabular}

Tabela 15. Número de OTUs e índices de alfa-diversidade estimados para as sequências dos pontos amostrais do manguezal de Cananéia obtidas através do pirosequenciamento do gene $16 \mathrm{~S}$ rRNA.

\begin{tabular}{|c|c|c|c|c|c|c|c|c|}
\hline \multirow{2}{*}{ Biblioteca } & \multirow{2}{*}{$N^{0}$ Seqs } & \multirow{2}{*}{ Cutoff } & \multirow{2}{*}{ OTUs } & \multicolumn{2}{|c|}{ Riqueza } & \multicolumn{2}{|c|}{ Diversidade } & \multirow{2}{*}{$\begin{array}{c}\text { Cobertura } \\
\% \\
\end{array}$} \\
\hline & & & & Chao1 & ACE & Shannon & Simpson & \\
\hline \multirow{4}{*}{ CP1 } & \multirow{4}{*}{4.848} & 0,03 & 1.879 & 4.981 & 9.052 & 6,32 & 0,017 & 0,73 \\
\hline & & 0,05 & 1.573 & 3.937 & 6.993 & 6,01 & 0,024 & 0,79 \\
\hline & & 0,10 & 1.076 & 2.072 & 2.796 & 5,42 & 0,036 & 0,88 \\
\hline & & 0,20 & 448 & 626 & 622 & 4,54 & 0,049 & 0,97 \\
\hline \multirow{4}{*}{ CP2 } & \multirow{4}{*}{5.007} & 0,03 & 2.097 & 5.467 & 9.605 & 6,76 & 0,006 & 0,71 \\
\hline & & 0,05 & 1.689 & 4.147 & 6.656 & 6,43 & 0,007 & 0,78 \\
\hline & & 0,10 & 1.125 & 2.146 & 3.143 & 5,81 & 0,011 & 0,88 \\
\hline & & 0,20 & 437 & 539 & 540 & 4,79 & 0,027 & 0,98 \\
\hline \multirow{4}{*}{ CP3 } & \multirow{4}{*}{4.098} & 0,03 & 1.804 & 4.888 & 9.101 & 6,77 & 0,003 & 0,69 \\
\hline & & 0,05 & 1.518 & 4.109 & 7.014 & 6,47 & 0,004 & 0,75 \\
\hline & & 0,10 & 1.043 & 2.228 & 3.500 & 5,87 & 0,007 & 0,85 \\
\hline & & 0,20 & 444 & 651 & 630 & 4,85 & 0,017 & 0,96 \\
\hline
\end{tabular}


Figura 36. Curvas de rarefação estimadas para o número total de sequências do gene $16 \mathrm{~S}$ rRNA de cada manguezal para os cutoffs de 0,03; 0,05, 0,10 e 0,20.

BA

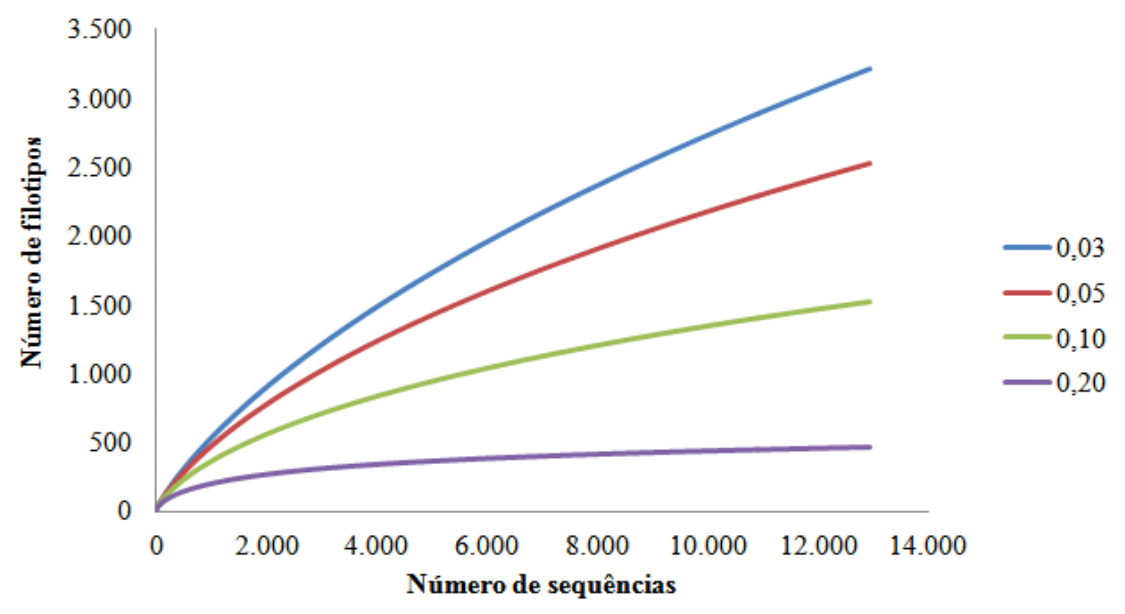

BC
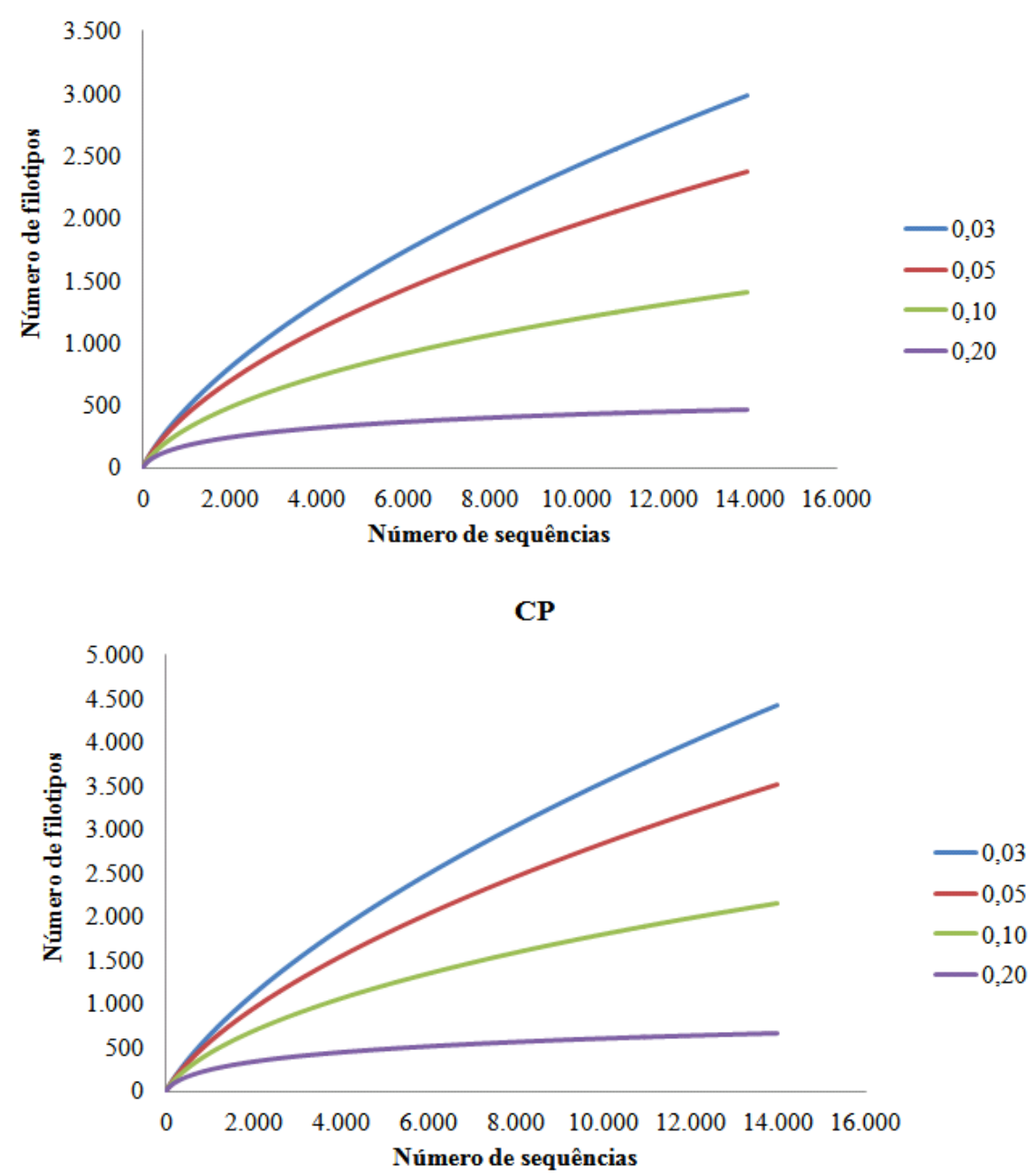

Ordenada: número de OTUs; Abscissa: número de sequências analisadas. 
Figura 37. Curvas de rarefação estimadas para o número total de sequências do gene $16 \mathrm{~S}$ rRNA obtidas em cada ponto amostral dos três manguezais para os cutoffs de 0,$03 ; 0,05 ; 0,10$ e 0,20 .
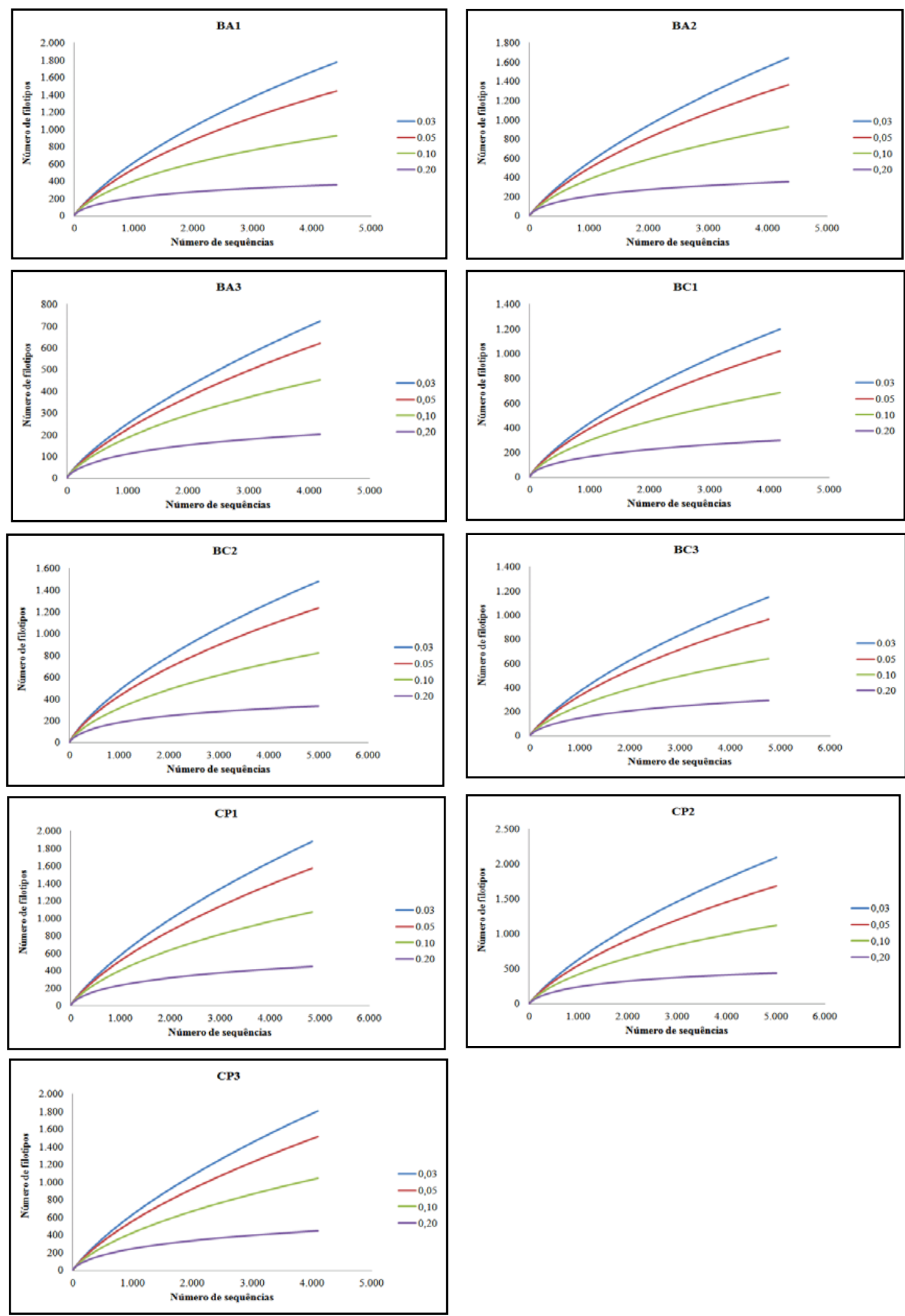

Ordenada: número de OTUs; Abscissa: número de sequências analisadas. 
Os estimadores Shannon e Simpson revelaram que as amostras BA3 e BC3 apresentaram as menores estimativas de diversidades quando comparadas a todas as demais amostras, em todos os cutoffs analisados. A baixa riqueza e diversidade observada para essas amostras pode ser reflexo do grande número de sequências identificadas como Fusibacter sp. (31,3\%) e Paracoccus sp. (25,7\%) na amostra BA3 e de Paracoccus sp., (29,1\%) e Rhodobacter sp. (25,6\%) na amostra BC3, demonstrando uma alta dominância desses gêneros nas comunidades bacterianas destes pontos amostrais.

A comparação da estrutura da comunidade por métodos baseados em OTU foi realizada para quantificar a riqueza compartilhada observada (sharedsobs) e estimada (sharedace e sharedchao) entre as amostras. Essa análise ecológica é denominada beta-diversidade. Os índices de beta-diversidade foram calculados entre as amostras de sedimento dos três manguezais analisados para o cutoff de 0,20 , pois este foi o único para o qual verificamos uma cobertura superior a 90\% para o manguezal de Cananéia. Os resultados estão apresentados na Tabela 16.

Tabela 16. Índices de beta-diversidade calculados entre as amostras dentro de cada manguezal para o cutoff de 0,20 .

\begin{tabular}{lcccccc}
\hline \multirow{2}{*}{$\begin{array}{c}\text { Amostras } \\
\text { comparadas }\end{array}$} & \multicolumn{5}{c}{ Índices de beta-diversidade* } \\
\cline { 3 - 7 } & Sharedsobs & Sharedace & Sharedchao & Jclass & Thetayc \\
\hline BA1 & BA2 & 277 & 375 & 411 & 0,625 & 0,505 \\
BA1 & BA3 & 164 & 227 & 228 & 0,412 & 0,083 \\
BA2 & BA3 & 169 & 220 & 243 & 0,432 & 0,132 \\
BC1 & BC2 & 223 & 318 & 300 & 0,540 & 0,593 \\
BC1 & BC3 & 194 & 263 & 278 & 0,487 & 0,359 \\
BC2 & BC3 & 222 & 305 & 279 & 0,544 & 0,610 \\
CP1 & CP2 & 321 & 407 & 455 & 0,569 & 0,209 \\
CP1 & CP3 & 300 & 397 & 472 & 0,507 & 0,219 \\
CP2 & CP3 & 287 & 361 & 351 & 0,483 & 0,549 \\
\hline
\end{tabular}

*Sharedsobs: número de OTUs compartihadas observadas; Sharedace: índice de ACE compartilhado; Sharedchao: índice de Chao1 compartilhado; Jclass: coeficiente de similaridade de Jaccard; Thetayc: coeficiente de similaridade theta de Yue-Clayton.

Observa-se nos dados obtidos com a análise de beta-diversidade que os índices de riqueza compartilhada (sharedsobs, sharedace e sharedchao) foram maiores entre as os pontos amostrais de Cananéia, especialmente quando se comparou os pontos CP1 com CP2 e CP1 
com CP3. Outra consideração importante é que para todos os manguezais os pontos P1 e P2 compartilham mais OTUs entre si do que com o ponto P3.

A similaridade dos membros da comunidade, quanto a sua estrutura, foi medida através dos coeficientes de abundância de Jaccard (Jclass) e Theta de Yue-Clayton (Thetayc). De acordo com estes coeficientes os pontos amostrais BA1 e BA2 foram os que apresentaram maior similaridade entre si com relação às comunidades microbianas.

Com o intuito de melhor representar os resultados das análises de riqueza compartilhada entre as amostras, também foram gerados diagramas de Venn para verificar as intersecções e peculiaridades de cada ambiente, identificando o número de OTUs exclusivas e compartilhadas entre os pontos de cada manguezal no cutoff de 0,20 (Figura 38). Infelizmente por conta do grande número de sequências comparadas, até o momento da entrega da tese não foi possível finalizar o diagrama de Venn com a comparação entre manguezais (BA-BC-CP), mas esta análise está sendo providenciada.

Pela análise dos diagramas de Venn foi possível confirmar uma maior quantidade de OTUs únicas nas sequências obtidas no manguezal de Cananéia em comparação com os demais manguezais amostrados. Fica evidente que os pontos amostrais P1 e P2 compartilham mais seqüências entre si, do que com o ponto P3 em todos os manguezais. Também é possível observar que nos manguezais BA e BC o ponto P3 é o que apresenta os menores números de OTUs únicas, ao contrário do observado para Cananéia.

No diagrama de Venn também é possível observar que apesar do manguezal de Cananéia apresentar um maior número de OTUs únicas em todos os pontos amostrais, a porcentagem de sequências compartilhadas entre os pontos ficou em torno de $30 \%$ do total de OTUs observadas para o cutoff de 0,20 para todos os manguezais. Em Bertioga Antropizado (BA) o total de OTUs detectadas foi de 464 e os três pontos amostrais compartilham 150 (32,3\%) OTUs entre si. Para Bertioga Contaminado (BC) o total de OTUs foi de 460, sendo que 169 (36,74\%) OTUs são compartilhadas por todos os pontos amostrais. E no manguezal de Cananéia 245(36,73\%) OTUs são compartilhadas entre os pontos amostrais, de um total de 667 OTUs detectadas para o cutoff de 0,20.

A beta diversidade também foi estimada através de teste de hipótese, o qual pode ser considerado alternativo aos métodos baseados em OTU. O teste utilizado foi o Libshuff que emprega testes de Monte Carlo (amostragens aleatórias) para estimar as diferenças entre cada comunidade, avaliando se a primeira comunidade é subamostra da segunda e se a estrutura da comunidade é mais variável do que o esperado pelo acaso. Em cada comparação, um valor de $p$ ( $p$-value) é gerado e, caso esteja abaixo do $p$ crítico, a hipótese é rejeitada. 
Figura 38. Diagramas de Venn representando o número de OTUs únicas e compartilhadas entre as amostras de cada manguezal. Valor de cutoff $=0,20$.

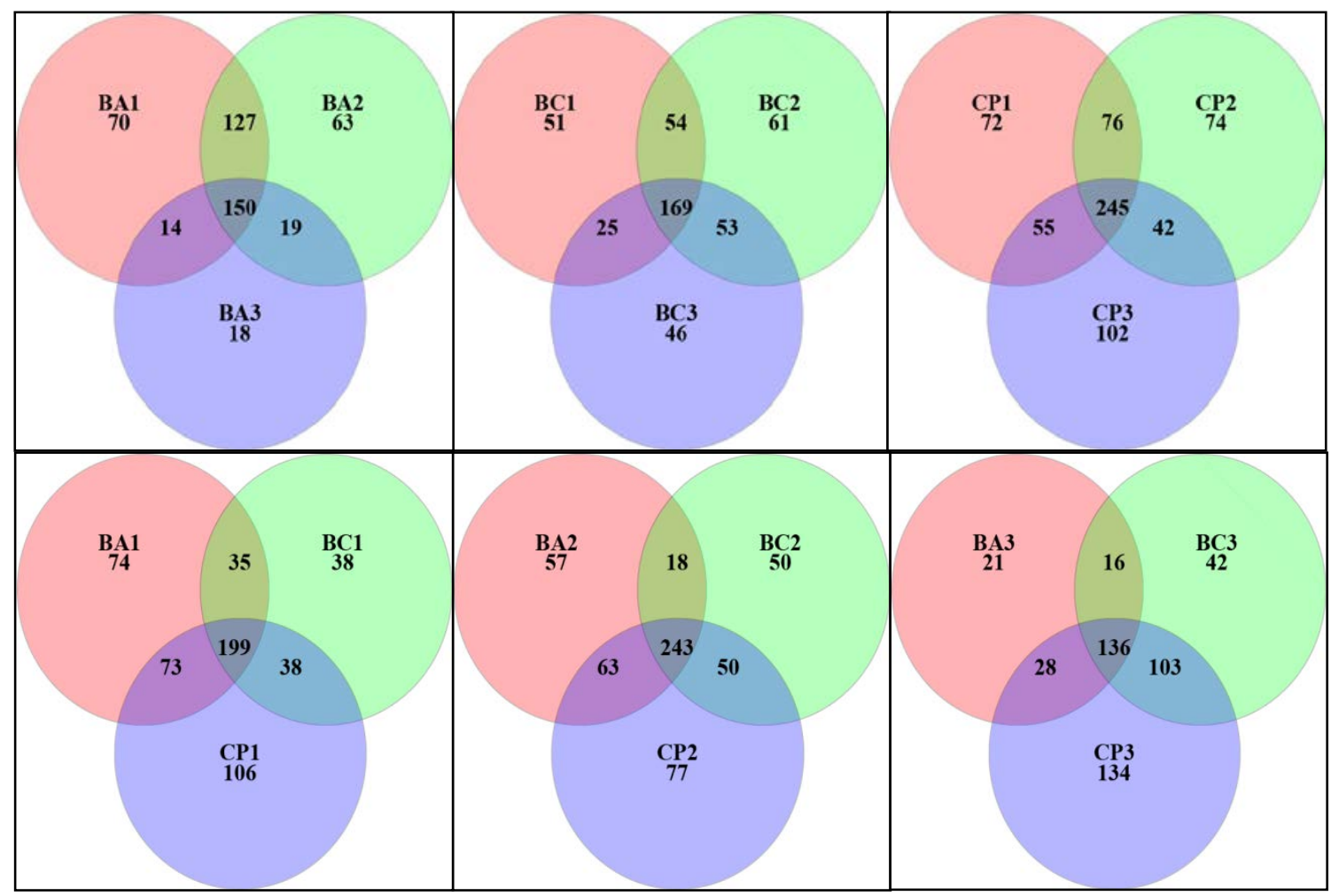

Os diagramas na parte superior representam a análise dentro de cada manguezal (BA), (BC), (CP) e aqueles na parte inferior representam a análise considerando os pontos (P1), (P2), (P3) nos diferentes manguezais.

Os resultados do teste de Libshuff estão apresentados na Tabela 17 e o p-value foi significativo para todos os pares de amostras analisados. Mais especificamente, se o resultado do teste mostra significância, então a comunidade de uma das amostras comparadas é significativamente diferente. A comparação do par reverso indica qual comunidade é subamostra da outra. Diante disso o teste revelou que para todas as amostras as comunidades são diferentes entre si. Cabe ressaltar que os testes baseados em hipóteses conseguem detectar diferenças estatisticamente significativas, mas não necessariamente representam uma diferença ecologicamente significativa.

Em virtude de todas as abordagens aqui realizadas, pode-se inferir que o agrupamento hierárquico comparando todos os manguezais entre si mostrou dois agrupamentos distintos, um com amostras de BA e outro com as amostras de BC, sendo que as amostras de CP mostraram-se intercaladas a estes dois grupamentos, mas CP1 mostrou-se distante de ambos. A abordagem multivariada (PCA) indicou uma maior proximidade dos pontos P1 e P2 para todas as amostras. Já os métodos baseados em OTU mostraram que o manguezal preservado (CP) alberga uma maior diversidade e riqueza de OTUs, apresentando também um maior 
número de sequências únicas e compartilhadas que os ambientes impactados (BA e BC) o que nos leva a acreditar que as alterações ambientais sofridas pelos manguezais de Bertioga podem ter levado a uma redução da diversidade na comunidade microbiana nesses ecossistemas. E por fim o teste de hipótese mostrou que todas as amostras são significativamente diferentes entre si.

Tabela 17. Teste de hipótese Libshuff entre as amostras dos três manguezais, sob um cutoff de 0,20 .

\begin{tabular}{cccc}
\hline $\begin{array}{c}\text { Amostras } \\
\text { Comparadas }\end{array}$ & dCXYScore & $\begin{array}{c}\text { Significância } \\
(\boldsymbol{p} \text {-value })\end{array}$ & Resultado $^{\mathbf{1}}$ \\
\hline BA1-BA2 & 0.00089950 & $<0.0001$ & Significativo \\
BA2-BA1 & 0.00040016 & $<0.0001$ & Significativo \\
BA1-BA3 & 0.00734085 & $<0.0001$ & Significativo \\
BA3-BA1 & 0.00347758 & $<0.0001$ & Significativo \\
BA2-BA3 & 0.00516282 & $<0.0001$ & Significativo \\
BA3-BA2 & 0.00305882 & $<0.0001$ & Significativo \\
BC1-BC2 & 0.00253960 & $<0.0001$ & Significativo \\
BC2-BC1 & 0.00182771 & $<0.0001$ & Significativo \\
BC1-BC3 & 0.00881158 & $<0.0001$ & Significativo \\
BC3-BC1 & 0.00445830 & $<0.0001$ & Significativo \\
BC2-BC3 & 0.00185031 & $<0.0001$ & Significativo \\
BC3-BC2 & 0.00127912 & $<0.0001$ & Significativo \\
CP1-CP2 & 0.00032111 & $<0.0001$ & Significativo \\
CP2-CP1 & 0.00097037 & $<0.0001$ & Significativo \\
CP1-CP3 & 0.00172975 & $<0.0001$ & Significativo \\
CP3-CP1 & 0.00213088 & $<0.0001$ & Significativo \\
CP2-CP3 & 0.00161846 & $<0.0001$ & Significativo \\
CP3-CP2 & 0.00168364 & $<0.0001$ & Significativo \\
\hline Significativo se $<<0,0083$ & & & \\
& & & \\
\hline
\end{tabular}




\subsection{Pirosequenciamento do gene bph}

O pirosequenciamento do gene bph que codifica a enzima bifenilo dioxigenase foi realizado com o objetivo de verificar a diversidade deste gene, que esteve presente em todas as amostras analisadas. Um total de 23.238 sequências nucleotídicas foram obtidas após remoção dos primers e tags e utilizando um comprimento mínimo de 400pb pelo uso da ferramenta FunGene Pipeline Initial Process, além da eliminação das sequências quiméricas pelo uso da ferramenta decipher.

Posteriormente as sequências válidas foram traduzidas in silico para as sequências de aminoácidos correspondentes, utilizando como filtro um comprimento mínimo de 130 aminoácidos e para reduzir o trabalho computacional optamos para trabalhar apenas com as sequências de aminoácidos que apresentaram um limiar de 60\% de identidade com as sequências de referência para o gene $b p h$ depositadas no banco de dados do FunGene.

No processo de tradução foram corrigidos os possíveis erros em relação às fases de leitura pelo uso da ferramenta Framebot, o que resultou em um total de 12.410 sequências de aminoácidos que foram alinhadas pelo uso da ferramenta Aligner e utilizados para as análises posteriores. A Tabela 18 apresenta uma descrição do número de sequências válidas, o comprimento médio das sequências obtidas por amostra e as sequências que foram traduzidas em proteínas funcionais.

Tabela 18. Descrição das amostras submetidas ao pirosequenciamento para o gene $b p h$, número total e comprimento médio das sequências.

\begin{tabular}{|c|c|c|c|c|}
\hline Amostras & $\begin{array}{c}\text { Sequências } \\
\text { nucleotídicas } \\
\text { válidas } \\
\end{array}$ & $\begin{array}{c}\text { Comprimento } \\
\text { médio das } \\
\text { sequências (pb) }\end{array}$ & $\begin{array}{l}\text { Sequências de } \\
\text { aminoácidos }\end{array}$ & $\begin{array}{l}\text { Número de } \\
\text { sequências } \\
\text { funcionais } \\
\end{array}$ \\
\hline BA1 & 3.115 & 454 & 1.642 & \\
\hline BA2 & 2.963 & 452 & 1.608 & 3.967 \\
\hline ВA3 & 1.775 & 459 & 717 & \\
\hline BC1 & 3.520 & 459 & 1.679 & \\
\hline BC2 & 2.760 & 460 & 1.937 & 4.755 \\
\hline BC3 & 3.019 & 462 & 1.139 & \\
\hline CP1 & 2.262 & 457 & 1.462 & \\
\hline CP2 & 2.360 & 455 & 1.444 & 3.688 \\
\hline \multirow[t]{2}{*}{ CP3 } & 1.464 & 450 & 782 & \\
\hline & 23.238 & & 12.410 & \\
\hline
\end{tabular}

$\mathrm{pb}=$ pares de base 
Observa-se na Tabela 18 que o maior número de sequências foi obtido para o manguezal de Bertioga Contaminado e o menor número foi observado para o Manguezal de Cananéia, sendo que o comprimento médio das sequências nucleotídicas ficou entre 450 e 460 pares de base.

A composição da comunidade bacteriana que possui o gene bph em cada manguezal foi caracterizada pela classificação comparativa com o banco de dados do NCBI GenBank utilizando-se as ferramenta Blastx e Tbastx, para novamente confirmar as possíveis funções dos fragmentos sequenciados. Todas as sequências produziram alinhamentos significativos com sequências de dioxigenases da família Tolueno/Bifenilo depositadas no GenBank, a maioria associada a genes de Bacteria dos gêneros Pseudomonas, Rhizobium, Rhodococcus, Mycobacterium, Microbacterium e Burkholderia.

As Figuras 39 e 40 mostram as diferenças de abundância dos principais gêneros bacterianos que apresentam o gene bph em cada manguezal e por amostra analisada. Esta afiliação permitiu observar diferenças entre as áreas estudadas, onde fica evidente que as comunidades bacterianas com capacidade genética para degradação de bifenilo são heterogêneas nesses ambientes.

Os resultados sugerem uma maior heterogeneidade no manguezal BA, especialmente nos pontos BA1 e BA2 o que concorda com todos os dados obtidos anteriormente, pois as medidas de HPAs indicaram que a concentração de bifenilo foi maior no ponto BA1 (Tabela 2), as informações das bibliotecas construídas com o gene $\alpha$-ARHD demonstraram uma maior frequência de enzimas associadas à degradação de bifenilo em BA1 (Figura 19) e as informações da PCA também sugerem uma maior correlação do bifenilo com os pontos amostrais BA1 e BA2 (Figura 35).

Um total de 55 gêneros bacterianos foram detectados no manguezal BA e os que apresentaram maior abundância são Pseudomonas (14\%), Rhodococcus (12\%), Microbacterium (9\%), Achromobacter (6\%), Meiothermus (5\%), Mycobacterium (5\%) e Sphingomonas (5\%).

Infelizmente nenhum dos micro-organismos detectados via pirosequenciamento do gene $b p h$ foi isolado no enriquecimento realizado com bifenilo no manguezal BA, mas um fator muito importante a se considerar é que para a caracterização dos isolados optamos pelo gene 16S rRNA que possui um banco de dados mais robusto e garante uma maior confiabilidade na identificação, ao contrário do gene $b p h$ cujo número de sequências depositadas no banco de dados ainda é limitado. Além disso, é importante enfatizar a existência de eventos genéticos como transferência gênica horizontal (TGH), que ocorre naturalmente via aquisição 
microbiana de elementos genéticos móveis como plasmídeos e transposons, e de eventos como recombinação, duplicação, mutação pontual múltipla, deleção e integração gênica, que são formas de evolução constante dos micro-organismos para que consigam realizar, através de novas vias metabólicas adquiridas, a degradação de diversos substratos inseridos no ambiente (NOJIRI et al., 2004; SPRINGAEL et al., 2004).

No manguezal de Bertioga Contaminado verificamos a presença de 40 gêneros bacterianos que possuem o gene bph e estes foram representados por Pseudomonas (69\%), Rhizobium (10\%), Mycobacterium (8\%) e Gordonia (5\%). Vale ressaltar que esse foi o manguezal que apresentou a maior abundância do gênero Pseudomonas, especialmente no ponto BC1 $(96,96 \%)$ que foi o único ponto amostral para o qual foi possível isolar microorganismos deste gênero pelo processo de enriquecimento com bifenilo.

Em Cananéia foram detectados 51 gêneros bacterianos dos quais Pseudomonas (49\%), Rhizobium (15\%) e Burkholderia (7\%) foram os principais representantes. Ao contrário do que esperávamos, o gênero Lysinibacillus que apresentou uma grande frequência nas amostras de Cananéia pelo pirosequenciamento do 16S rRNA e que foi o único isolado pelo enriquecimento com bifenilo neste ambiente, não foi detectado no pirosequenciamento usando o gene $b p h$. Uma possível explicação é a carência de sequências de dioxigenases relacionadas a este micro-organismo e ao gene bph nos bancos de dados.

Várias estratégias têm sido utilizadas para avaliar as relações entre o funcionamento dos ecossistemas e a estrutura de comunidades microbianas, com o objetivo de atribuir o papel de membros específicos dentro da comunidade. Desta forma, a abordagem metagenômica, onde as sequências de um dado gene de interesse são diretamente analisadas por meio de técnicas de sequenciamento em larga escala (pirosequenciamento), tem permitido o estudo mais detalhado da diversidade funcional dos membros da comunidade, especialmente daqueles que ainda não são cultiváveis e daqueles com grande importância biotecnológica (HANDELSMAN, 2004).

Vale ressaltar que embora os genes funcionais ofereçam menor conservação entre as sequências quando comparados a marcadores filogenéticos como o gene 16S rRNA, a abordagem metagenômica baseada em genes específicos, como utilizada neste estudo, revela muitas informações sobre a diversidade microbiana a que este gene está associado naquele ambiente. 
Figura 39. Abundância relativa dos principais gêneros de Bacteria, que apresentaram o gene bph em cada manguezal analisado, com base na afiliação filogenética do NCBI/GenBank utilizando-se a ferramenta Tblastx.
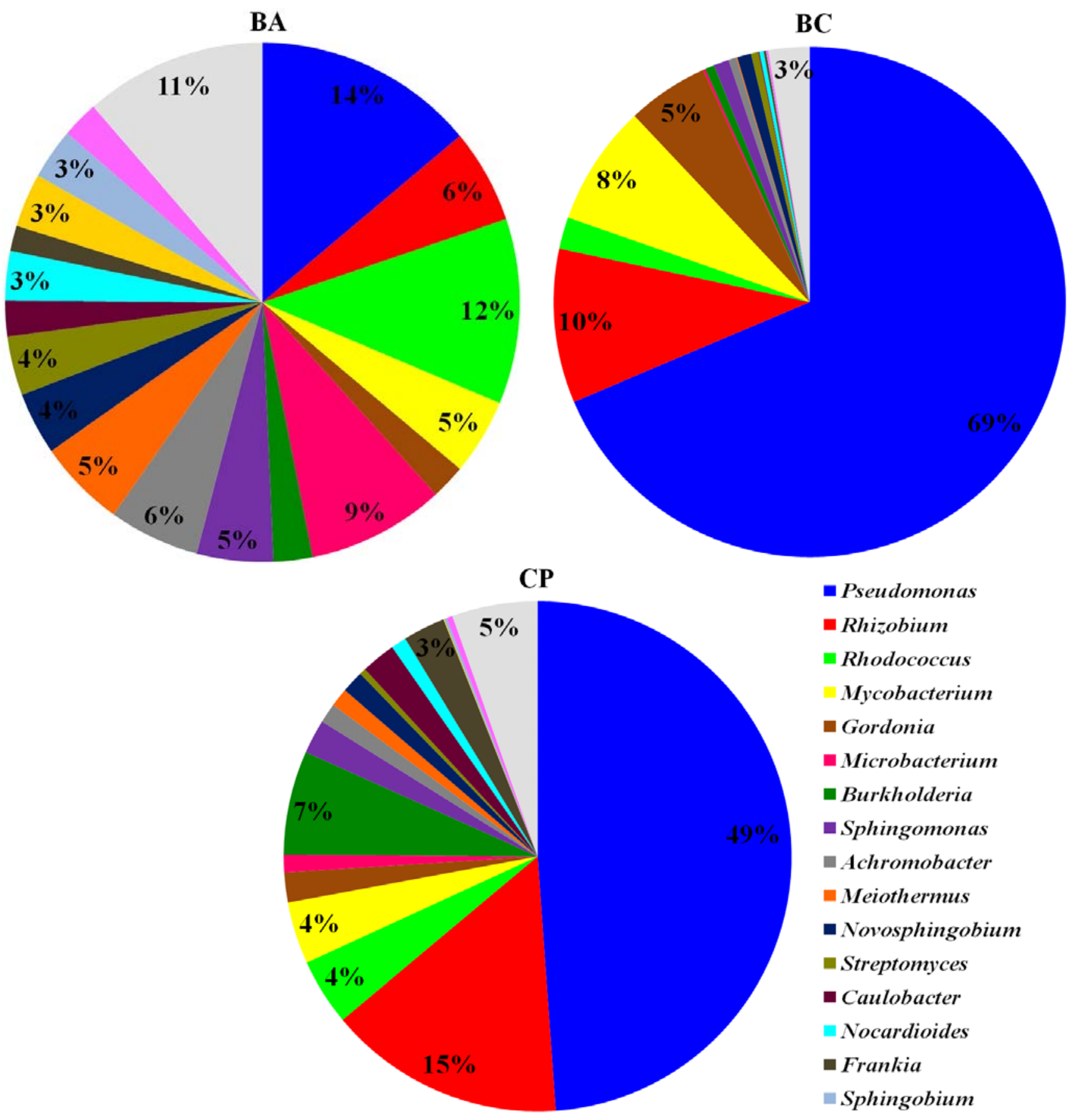

- Pseudomonas

- Rhizobium

Rhodococcus

Mycobacterium

- Gordonia

- Microbacterium

Burkholderia

- Sphingomonas

- Achromobacter

Meiothermus

- Novosphingobium

- Streptomyces

- Caulobacter

- Nocardioides

- Frankia

- Sphingobium

- Ralstonia

Outros

BA - Bertioga Antropizado, BC - Bertioga Contaminado e CP - Cananéia Preservado. 
Figura 40. Abundância relativa dos principais gêneros bacterianos que apresentam o gene $b p h$, em cada ponto amostral analisado, com base na afiliação filogenética do NCBI/GenBank utilizando-se a ferramenta Tblastx.

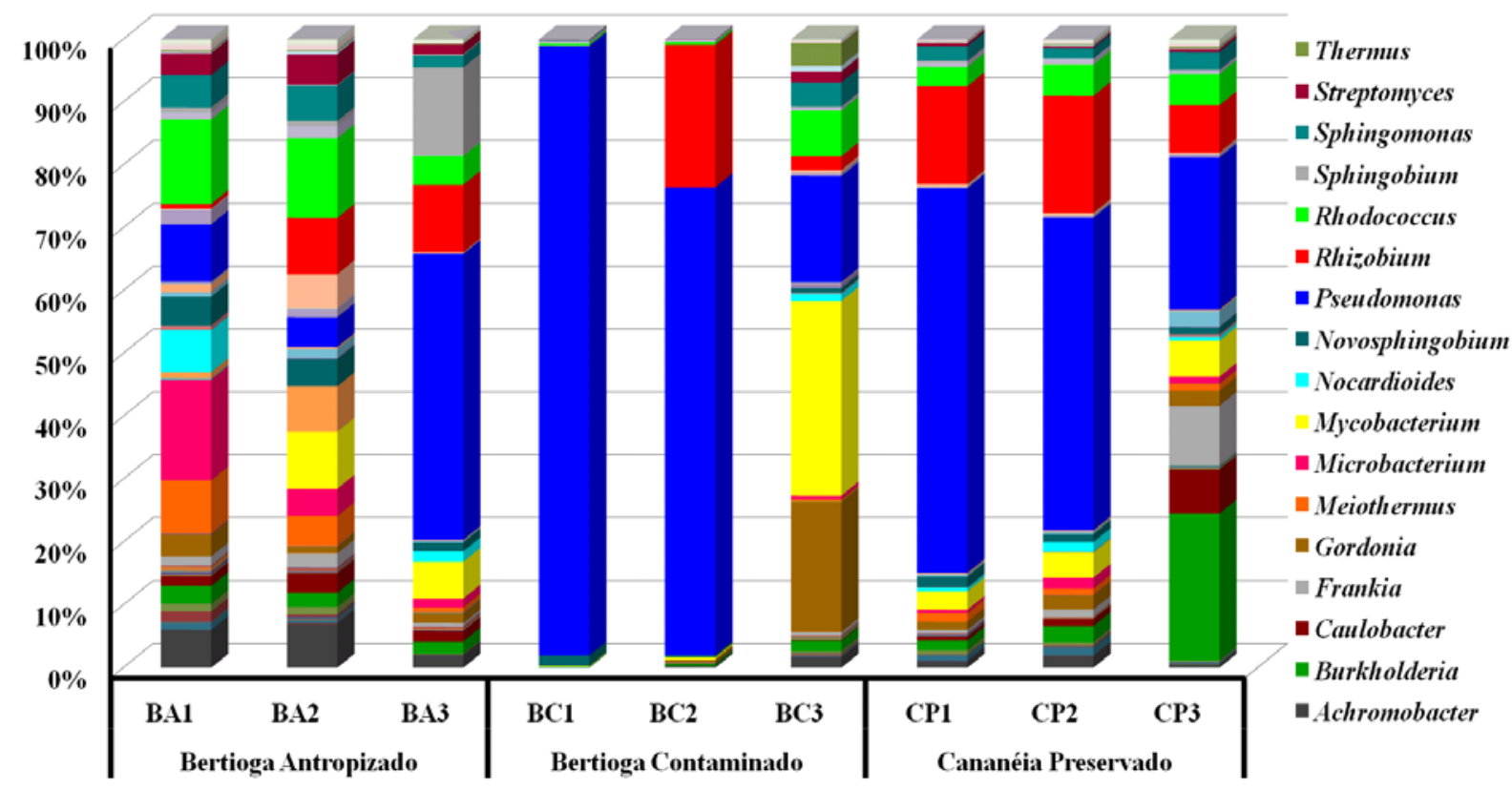

Os manguezais aqui estudados também foram avaliados quanto ao seu agrupamento hierárquico a partir de uma matriz construída com a abundância dos gêneros em cada ponto amostral. Novamente aqui um dendograma de distância euclidiana foi gerado representado por perfis de intensidade de cores, como pode ser observado na Figura 41.

Nesta análise, realizada unicamente com os dados de abundância dos gêneros bacterianos associados ao gene $b p h$, observa-se que não houve um padrão de agrupamento entre os manguezais e os pontos amostrais. As informações importantes a se considerar são:

a) Os pontos BA1 e BA2 foram aqueles que se apresentaram correlacionados ao maior número de gêneros bacterianos;

b) o ponto BA1 foi aquele que mais se diferenciou dos demais, apresentando correlação positiva com os gêneros Meiothermus, Microbacterium, Rhodococcus, Nocardioides, Sphingomonas, Achromobacter e Novosphingobium;

c) o ponto BA2 apresentou-se correlacionado aos gêneros Rhodococcus, Ralstonia, Sphingomonas, Achromobacter, Streptomyces, Rhizobium, Mycobacterium, Meiothermus e Novosphingobium;

d) O gênero Pseudomonas foi aquele que mais se diferenciou dos demais, estando correlacionado aos pontos amostrais BA3, BC1, BC2, CP1 e CP2. 
Figura 41. Mapa de cores com análise de agrupamento as amostras baseado na abundância de gêneros bacterianos encontrados pela análise do gene $b p h$.

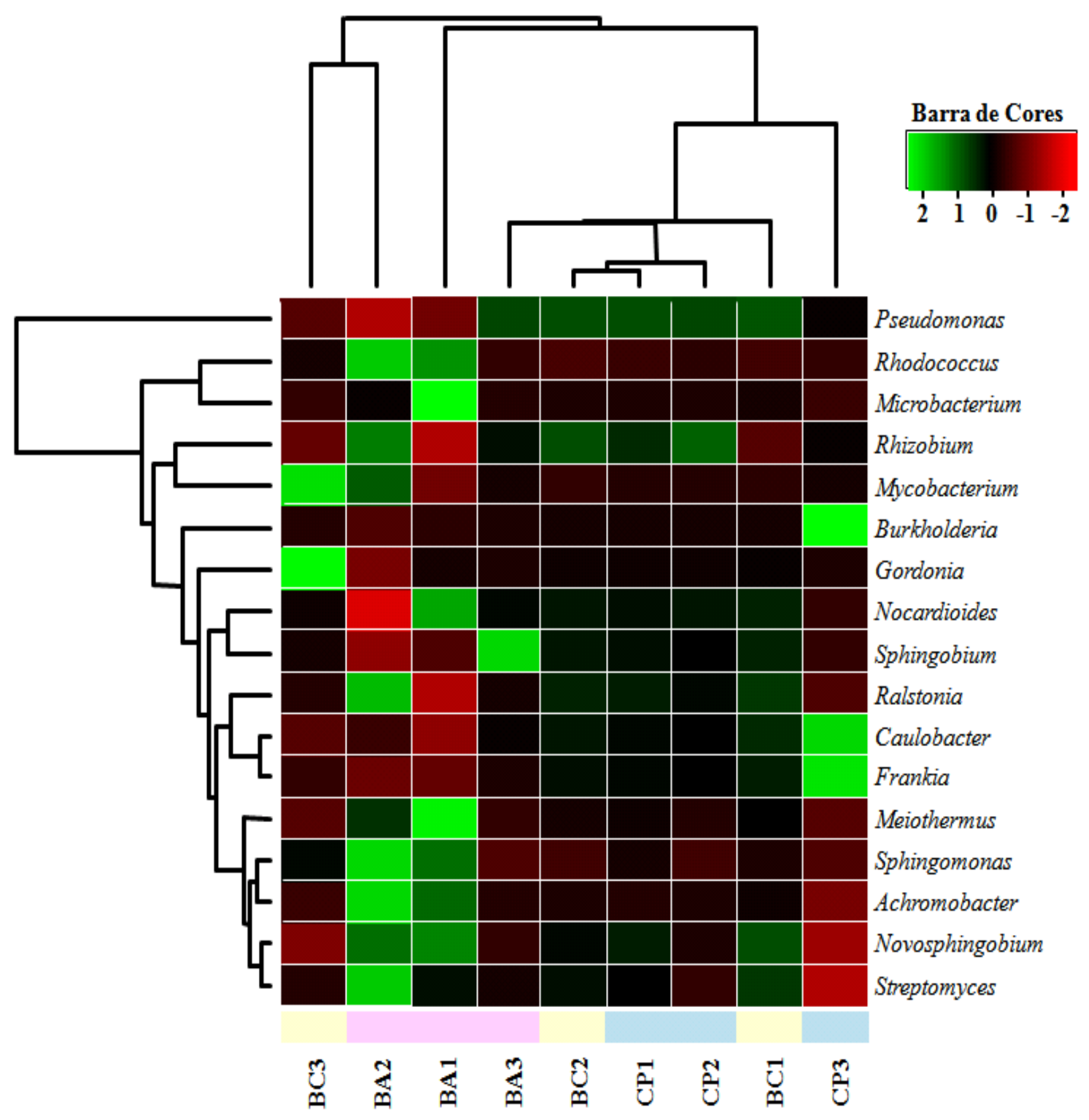

As colunas representam as amostras e as linhas representam os gêneros encontrados.

Em nosso estudo, a variação na comunidade microbiana observada a partir do pirosequenciamento para o gene $b p h$, também foi correlacionada, pela Análise de Componentes Principais (PCA), com os dados físico-químicos e concentrações de HPAs para cada ponto amostral analisado. Os gráficos resultantes desta correlação podem ser visualizados na Figura 42-A-B-C. 
Figura 42. Análise de Componentes Principais correlacionando os gêneros bacterianos associados ao gene $b p h$, as características físico-químicas e concentrações de HPAs para cada amostra de sedimento analisada.

A

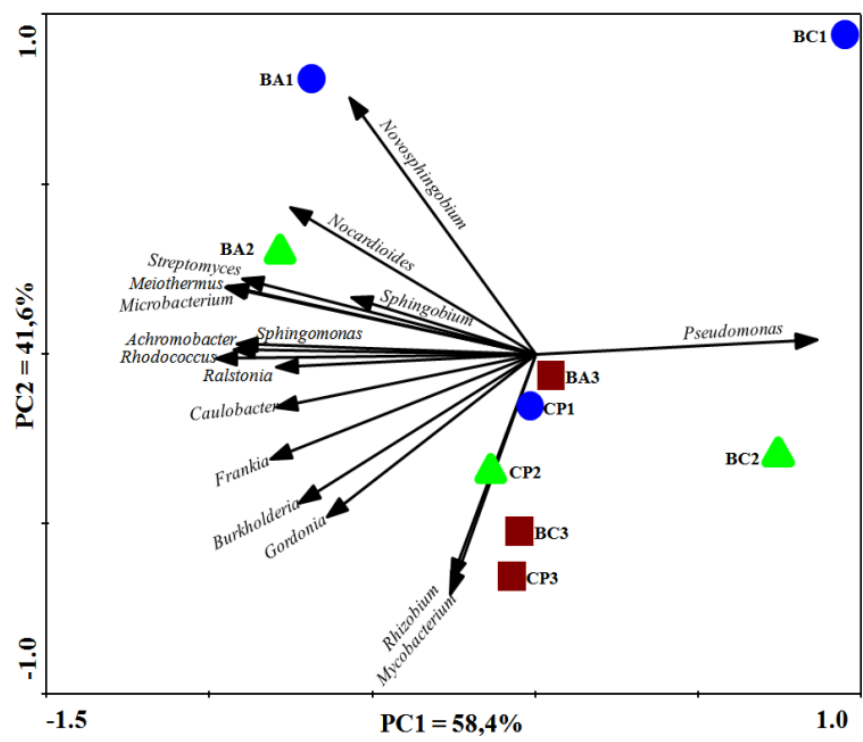

B

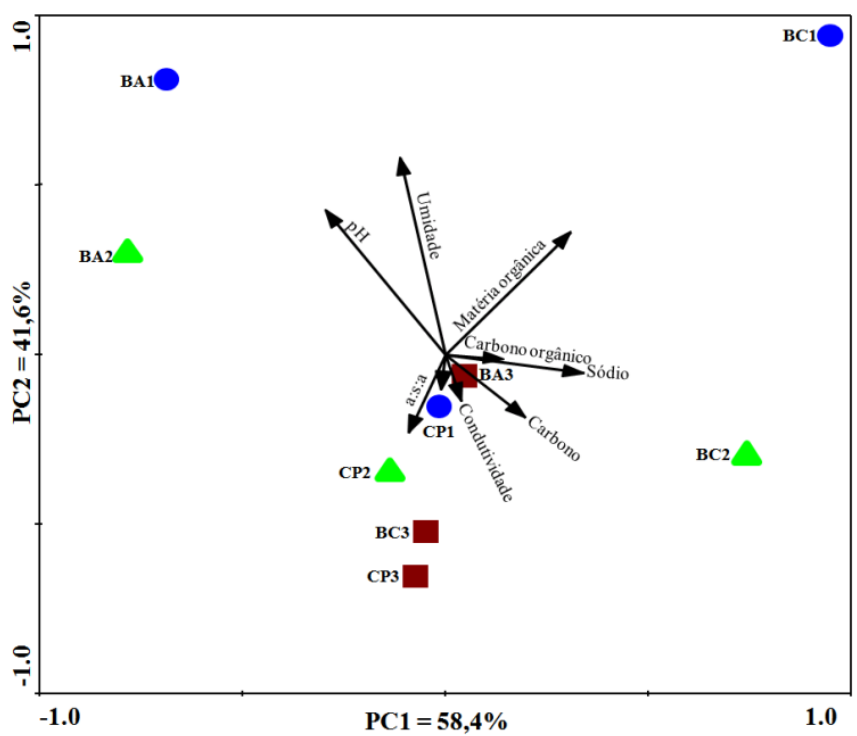

C

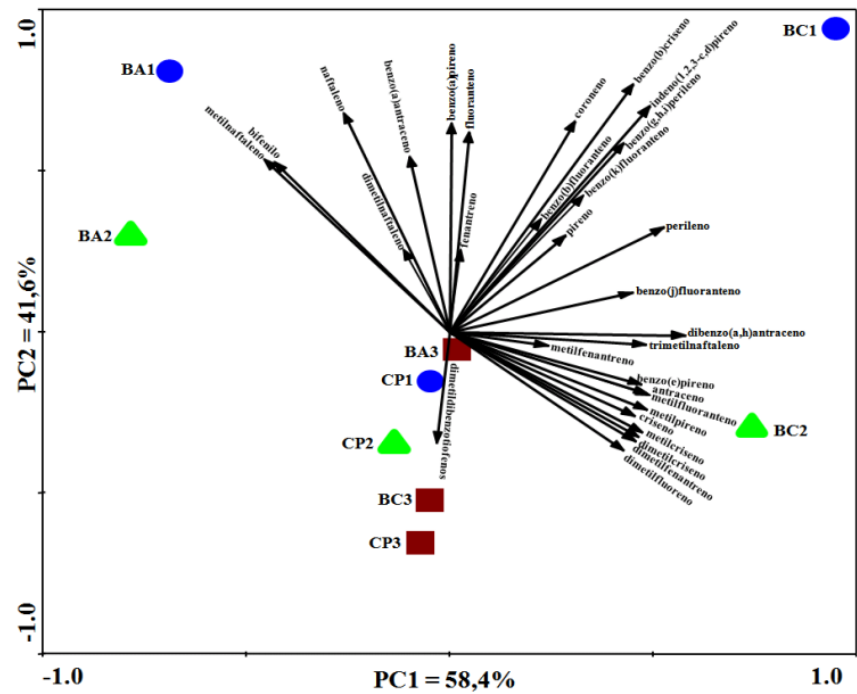

Curso d’água

Floresta

Restinga
Os gráficos foram plotados considerando-se as seguintes variáveis: (A) - Ponto Amostral x gêneros; (B) - Ponto Amostral $x$ Físico-químicos e (C) - Ponto Amostral x Hidrocarbonetos. 
De forma geral a PCA, considerando todos os fatores bióticos e abióticos aqui analisados, mostrou que o manguezal de Cananéia foi o único cujos pontos amostrais ficaram agrupados (CP1, CP2 e CP3), estando eles associados às áreas de restinga (BA3 e BC3) dos outros manguezais. Para os demais manguezais observou-se um distanciamento dos pontos P1 (curso d’água) e P2 (floresta), sendo que para o manguezal BA essa separação foi menos evididente que para o manguezal BC.

Os pontos CP1, CP2, CP3, BA3 e CP3 apresentaram maior correlação com os gêneros Rhizobium e Mycobacterium, além de uma associação ao HPA dimetildibenzotiofeno. Mas destes pontos amostrais, somente CP1 e BA3 mostraram-se correlacionados a fatores físicoquímicos, sendo que CP1 correlacionou-se a areia:silte:argila, salinidade e condutividade e BA3 mostrou-se associado a carbono, condutividade e sódio. Os pontos amostrais BC1 e BC2 apresentaram apenas associados ao gênero Pseudomonas. Com relação aos HPAs, nota-se que BC1 mostrou-se correlacionado com indeno(1,2,3-c,d)pireno, benzo(g,h,j)perileno e benzo(k)fluoranteno, enquanto BC2 correlaciona com benzo(e)pireno, antraceno, metilfluoranteno, metilpireno e criseno.

Pela ordenação das amostras observa-se que o ponto BA1 apresentou forte correlação com o gênero Novosphingobium e com os HPAs bifenilo e metilnaftaleno. Essa correlação do ponto BA1 com o substrato bifenilo já havia sido mostrada na Figura 17, assim como uma maior frequência relativa da enzima bifenilo dioxigenase (Figura 19) nesse ponto amostral. Já o ponto BA2 mostrou interação com o os gêneros Nocardioides, Sphingobium, Streptomyces, Meiothermus e Microbaterium, mas não apresentou correlações com fatores físico-químicos e concentração de HPAs.

Nos estudos envolvendo estudo da diversidade de dioxigenases que degradam compostos aromáticos, os valores de cutoff descritos na literatura apresentam valores altamente variáveis para a definição de Famílias Proteicas Operacionais (OPFs). Iwai et al. (2010) utilizaram um cutoff de 0,6 para determinação de OPFs de bifenilo dioxigenase utilizando amostras de uma área contaminada com bifenilo. Lee et al. (2011) usaram um cutoff de 0,5 para definição de novos grupos ativos relacionados à degradação de bifenilo. Trabalhando com amostras da Antártica Kuhn (2007) definiu um cuttof de 0,18 enquanto Jurelevicius et al. (2012) trabalharam com um cutoff de 0,10 para análise de dioxigenases aromáticas. Já Silva (2011) optaram por um cutoff de 0,05 para análise da diversidade de ARHDs e um cutoff de 0,06 para análise do gene bph em amostras de solo de Terra Preta de Índio na Amazônia. Tal variedade de níveis de distância filogenética muitas vezes dificulta uma comparação entre os resultados. Além deste fator, o número de OPFs detectados em uma 
dada amostra, ou o número de organismos em um dado nível filogenético, é fortemente influenciado pelo número de sequências analisadas (SCHLOSS et al., 2006), que variam enormemente entre os trabalhos.

Em nosso estudo o método de análise baseado na geração de OPFs foi utilizado nos intervalos de cutoff 0,03; 0,05; 0,10 e 0,20 para o cálculo dos índices de riqueza, estimativas de diversidade e análise de esforço amostral das comunidades microbianas. Inicialmente os cálculos foram realizados entre as sequências dos manguezais BA, BC e CP (Tabela 19) e posteriormente para cada uma das amostras analisadas neste estudo (Tabelas 20 a 22).

Considerando-se a análise geral, feita por manguezal (Tabela 19) é possível verificar que o manguezal de Bertioga Antropizado foi aquele que apresentou o maior número de OPFs $(\mathrm{n}=832)$ e os maiores índices de riqueza (Chao1=1.835 e ACE = 2.777) e estimativas de diversidade (Shannon $=5,39$ e Simpson=0,015), mas a análise de esforço amostral indicou que não obtivemos uma cobertura superior a $90 \%$ no cutoff 0,20 para esse manguezal. Em contrapartida o manguezal de Bertioga Contaminado apresentou o menor número de OPFs (318) e também os menores índices de riqueza (Chao1=784 e ACE=1.389) e estimativas de diversidade (Shannon=2,70 e Simpson=0,169), apresentando uma cobertura de 96\% no cutoff de 0,20 .

Os resultados da análise intra-manguezal, mostrou que os pontos amostrais BA2 e BA1 de Bertioga Antropizado apresentam os maiores números de OPFs ( $n=479$ e $n=450)$ e os maiores índices de riqueza e estimativas de diversidade, quando comparados a todos os demais pontos dos outros manguezais. Os estimadores Shannon e Simpson revelaram que as amostras BC1 e BC2 apresentaram as menores estimativas de diversidades quando comparadas a todas as demais amostras, para todos os cutoffs analisados. A baixa riqueza e diversidade observada para esses pontos amostrais pode ser reflexo do grande número de sequências identificadas como Pseudomonas sp. (96,96\%) na amostra BC1 e de Pseudomonas sp., (74,45\%) e Rhizobium sp. (22,66\%) na amostra BC2, demonstrando uma alta dominância desses gêneros nas comunidades bacterianas destes pontos amostrais.

As estimativas do número de OPFs variam em função do número de sequências analisadas, e esta relação pode ser verificada pelas curvas de rarefação. As curvas por manguezal (Figura 43) demonstraram que o manguezal de BC foi aquele que apresentou as maiores porcentagens de cobertura. Já as curvas considerando os diferentes pontos amostrais dentro de cada manguezal (Figura 44), demonstraram que uma cobertura superior a 90\% só foi contemplada para os pontos amostrais BC1, BC2 e CP1, indicando que o esforço amostral não foi suficiente para cobrir a riqueza de OPFs nas demais amostras sob cutoff de 0,20. 
Tabela 19. Número de OPFs e índices de alfa-diversidade estimados para as sequências de aminoácidos obtidas através do pirosequenciamento para o gene bph para cada manguezal.

\begin{tabular}{ccccccccc}
\hline \multirow{2}{*}{ Biblioteca } & \multirow{2}{*}{$\mathbf{N}^{\mathbf{0}}$ Seqs } & \multirow{2}{*}{ Cutoff } & \multirow{2}{*}{ OPFs } & \multicolumn{2}{c}{ Riqueza } & \multicolumn{2}{c}{ Diversidade } & Cobertura \\
& & & & Chao1 & ACE & Shannon & Simpson & \% \\
\hline \multirow{4}{*}{ BA } & \multirow{3}{*}{3.967} & 0,03 & 1.068 & 2.966 & 5.376 & 5,68 & 0,013 & 0,82 \\
& & 0,05 & 1.007 & 2.582 & 4.645 & 5,60 & 0,013 & 0,83 \\
& & 0,10 & 924 & 2.221 & 3.728 & 5,50 & 0,014 & 0,85 \\
& & $\mathbf{0 , 2 0}$ & $\mathbf{8 3 2}$ & $\mathbf{1 . 8 3 5}$ & $\mathbf{2 . 7 7 7}$ & $\mathbf{5 , 3 9}$ & $\mathbf{0 , 0 1 5}$ & $\mathbf{0 , 8 8}$ \\
$\mathbf{3}$ & & 0,03 & 454 & 1.141 & 1.869 & 3,07 & 0,146 & 0,94 \\
& \multirow{3}{*}{4.755} & 0,05 & 409 & 1.125 & 2.217 & 2,94 & 0,153 & 0,94 \\
& & 0,10 & 365 & 891 & 1.764 & 2,82 & 0,161 & 0,95 \\
& & $\mathbf{0 , 2 0}$ & $\mathbf{3 1 8}$ & $\mathbf{7 8 4}$ & $\mathbf{1 . 3 8 9}$ & $\mathbf{2 , 7 0}$ & $\mathbf{0 , 1 6 9}$ & $\mathbf{0 , 9 6}$ \\
$\mathbf{C P}$ & \multirow{3}{*}{3.688} & 0,03 & 698 & 1.758 & 2.751 & 3,93 & 0,140 & 0,88 \\
& & 0,05 & 640 & 1.683 & 2.642 & 3,78 & 0,150 & 0,89 \\
& & 0,10 & 575 & 1.398 & 2.148 & 3,63 & 0,162 & 0,90 \\
& & $\mathbf{0 , 2 0}$ & $\mathbf{5 1 2}$ & $\mathbf{1 . 1 2 6}$ & $\mathbf{1 . 7 3 9}$ & $\mathbf{3 , 4 9}$ & $\mathbf{0 , 1 7 3}$ & $\mathbf{0 , 9 2}$ \\
\hline
\end{tabular}

Tabela 19. Número de OPFs e índices de alfa-diversidade estimados para as sequências de aminoácidos obtidas através do pirosequenciamento para o gene bph para os pontos amostrais do manguezal de Bertioga Antropizado

\begin{tabular}{|c|c|c|c|c|c|c|c|c|}
\hline \multirow{2}{*}{ Biblioteca } & \multirow{2}{*}{$\mathbf{N}^{0}$ Seqs } & \multirow{2}{*}{ Cutoff } & \multirow{2}{*}{ OPFs } & \multicolumn{2}{|c|}{ Riqueza } & \multicolumn{2}{|c|}{ Diversidade } & \multirow{2}{*}{$\begin{array}{c}\text { Cobertura } \\
\% \\
\end{array}$} \\
\hline & & & & Chao1 & ACE & Shannon & Simpson & \\
\hline \multirow{4}{*}{ BA1 } & \multirow{4}{*}{1.642} & 0,03 & 568 & 1.688 & 2.610 & 5,50 & 0,010 & 0,77 \\
\hline & & 0,05 & 539 & 1.532 & 2.487 & 5,42 & 0,010 & 0,78 \\
\hline & & 0,10 & 500 & 1.342 & 2.142 & 5,34 & 0,011 & 0,80 \\
\hline & & 0,20 & 450 & 1.022 & 1.519 & 5,21 & 0,012 & 0,84 \\
\hline \multirow{4}{*}{ BA2 } & \multirow{4}{*}{1.608} & 0,03 & 581 & 1.464 & 2.846 & 5,48 & 0,013 & 0,76 \\
\hline & & 0,05 & 553 & 1.379 & 2.621 & 5,41 & 0,013 & 0,77 \\
\hline & & 0,10 & 523 & 1.232 & 2.204 & 5,35 & 0,014 & 0,79 \\
\hline & & 0,20 & 479 & 1.023 & 1.678 & 5,25 & 0,014 & 0,82 \\
\hline \multirow{4}{*}{ BA3 } & \multirow{4}{*}{717} & 0,03 & 178 & 486 & 1.126 & 3,29 & 0,147 & 0,82 \\
\hline & & 0,05 & 168 & 484 & 1.193 & 3,17 & 0,159 & 0,83 \\
\hline & & 0,10 & 161 & 454 & 1.049 & 3,12 & 0,164 & 0,84 \\
\hline & & 0,20 & 151 & 491 & 982 & 3,04 & 0,167 & 0,85 \\
\hline
\end{tabular}


Tabela 20. Número de OPFs e índices de alfa-diversidade estimados para as sequências de aminoácidos obtidas através do pirosequenciamento para o gene bph para os pontos amostrais do manguezal de Bertioga Contaminado.

\begin{tabular}{ccccccccc}
\hline \multirow{2}{*}{ Biblioteca } & \multirow{2}{*}{$\mathbf{N}^{\mathbf{0}}$ Seqs } & Cutoff & \multirow{2}{*}{ OPFs } & \multicolumn{2}{c}{ Riqueza } & \multicolumn{2}{c}{ Diversidade } & \multicolumn{2}{c}{ Cobertura } \\
Chao1 & & & ACE & Shannon & Simpson & \% \\
\hline \multirow{3}{*}{ BC1 } & \multirow{2}{*}{1.679} & 0,03 & 94 & 224 & 283 & 1,70 & 0,422 & 0,97 \\
& & 0,05 & 76 & 205 & 320 & 1,49 & 0,455 & 0,97 \\
& & 0,10 & 56 & 144 & 207 & 1,34 & 0,470 & 0,98 \\
& & 0,20 & 47 & 117 & 150 & 1,13 & 0,539 & 0,98 \\
BC2 & \multirow{3}{*}{1.937} & 0,03 & 111 & 264 & 306 & 1,53 & 0,449 & 0,97 \\
& & 0,05 & 91 & 256 & 298 & 1,40 & 0,470 & 0,97 \\
& & 0,10 & 74 & 209 & 233 & 1,30 & 0,486 & 0,98 \\
& & 0,20 & 60 & 179 & 217 & 1,24 & 0,491 & 0,98 \\
BC3 & \multirow{2}{*}{1.139} & 0,03 & 274 & 735 & 1.725 & 3,84 & 0,076 & 0,83 \\
& & 0,05 & 266 & 726 & 1.783 & 3,79 & 0,078 & 0,83 \\
& & 0,10 & 254 & 649 & 1.521 & 3,75 & 0,078 & 0,85 \\
& & 0,20 & 223 & 545 & 984 & 3,66 & 0,080 & 0,87 \\
\hline
\end{tabular}

Tabela 21. Número de OPFs e índices de alfa-diversidade estimados para as sequências de aminoácidos obtidas através do pirosequenciamento para o gene $b p h$ para os pontos amostrais do manguezal de Cananéia.

\begin{tabular}{ccccccccc}
\hline \multirow{2}{*}{ Biblioteca } & \multirow{2}{*}{$\mathbf{N}^{\mathbf{0}}$ Seqs } & Cutoff & \multirow{2}{*}{ OPFs } & \multicolumn{2}{c}{ Riqueza } & \multicolumn{2}{c}{ Diversidade } & Cobertura \\
Chao1 & ACE & Shannon & Simpson & \% \\
\hline \multirow{4}{*}{ CP1 } & \multirow{2}{*}{1.462} & 0,03 & 286 & 635 & 1.130 & 3,08 & 0,224 & 0,87 \\
& & 0,05 & 257 & 563 & 957 & 2,94 & 0,235 & 0,88 \\
& & 0,10 & 232 & 465 & 776 & 2,76 & 0,260 & 0,90 \\
& & 0,20 & 204 & 537 & 701 & 2,61 & 0,277 & 0,91 \\
$\mathbf{C P 2}$ & \multirow{2}{*}{1.444} & 0,03 & 330 & 794 & 1.261 & 3,58 & 0,148 & 0,85 \\
& & 0,05 & 306 & 708 & 1.079 & 3,48 & 0,155 & 0,86 \\
& & 0,10 & 280 & 581 & 917 & 3,33 & 0,167 & 0,88 \\
& & 0,20 & 257 & 521 & 710 & 3,23 & 0,177 & 0,89 \\
CP3 & \multirow{2}{*}{782} & 0,03 & 248 & 843 & 1.405 & 4,20 & 0,049 & 0,77 \\
& & 0,05 & 233 & 832 & 1.333 & 4,12 & 0,051 & 0,78 \\
& & 0,10 & 214 & 628 & 1.130 & 4,00 & 0,056 & 0,81 \\
& & 0,20 & 192 & 455 & 780 & 3,90 & 0,059 & 0,84 \\
\hline
\end{tabular}


Figura 43. Curvas de rarefação estimadas para o número total de sequências de aminoácidos do gene bph para cada manguezal para os cutoffs de 0,03; 0,05; 0,10 e 0,20.

BA

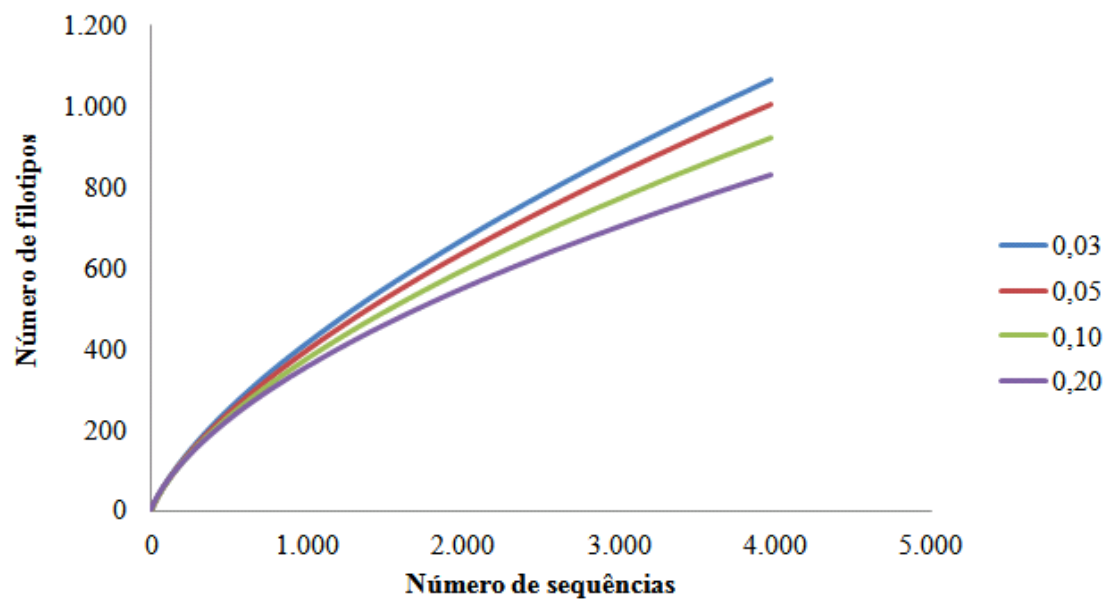

BC
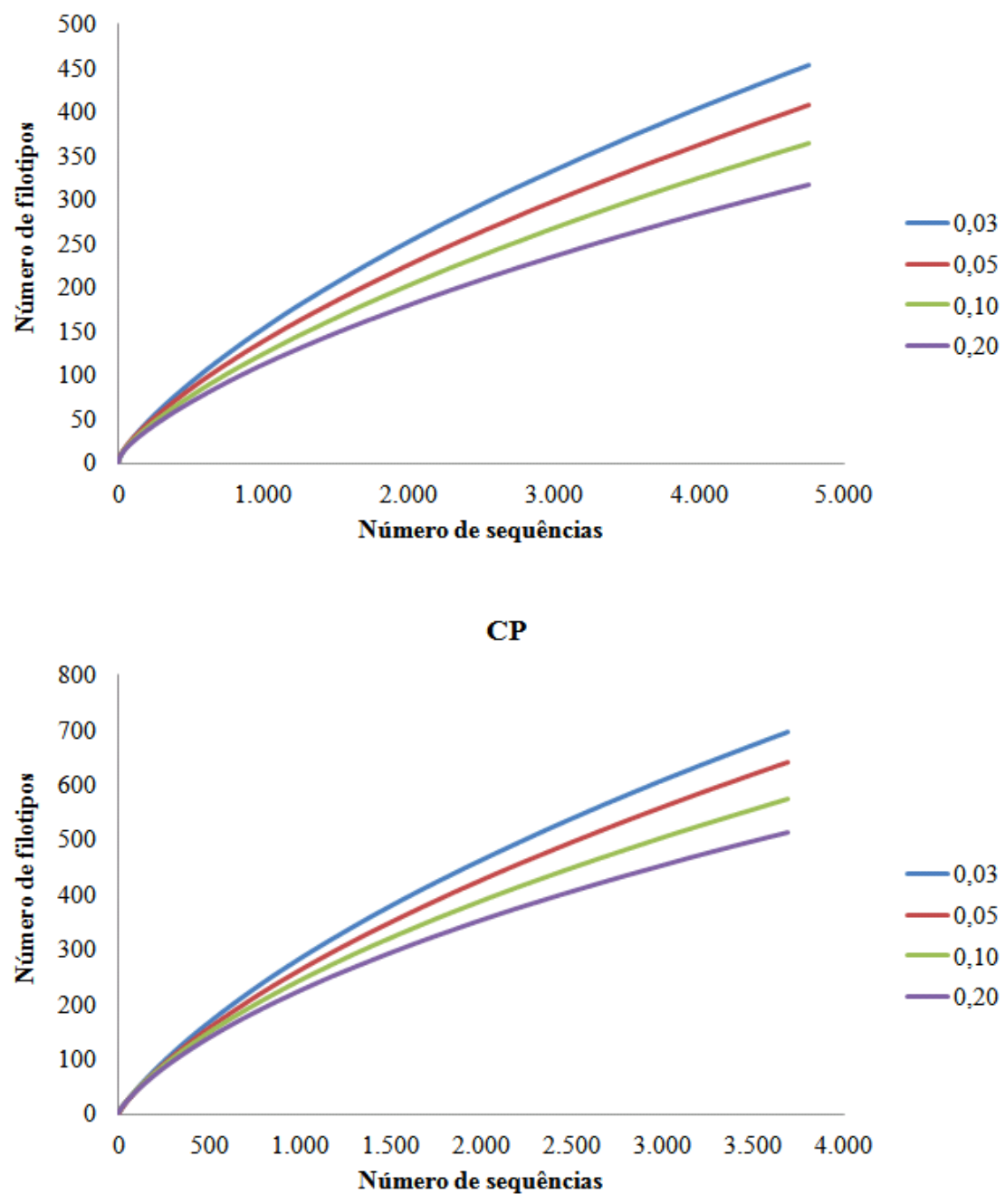

Ordenada: número de OTUs; Abscissa: número de sequências analisadas. 
Figura 44. Curvas de rarefação estimadas para as sequências de aminoácidos do gene $b p h$ para cada ponto amostral dos três manguezais para os cutoffs de 0,03; 0,05; 0,10 e 0,20 .
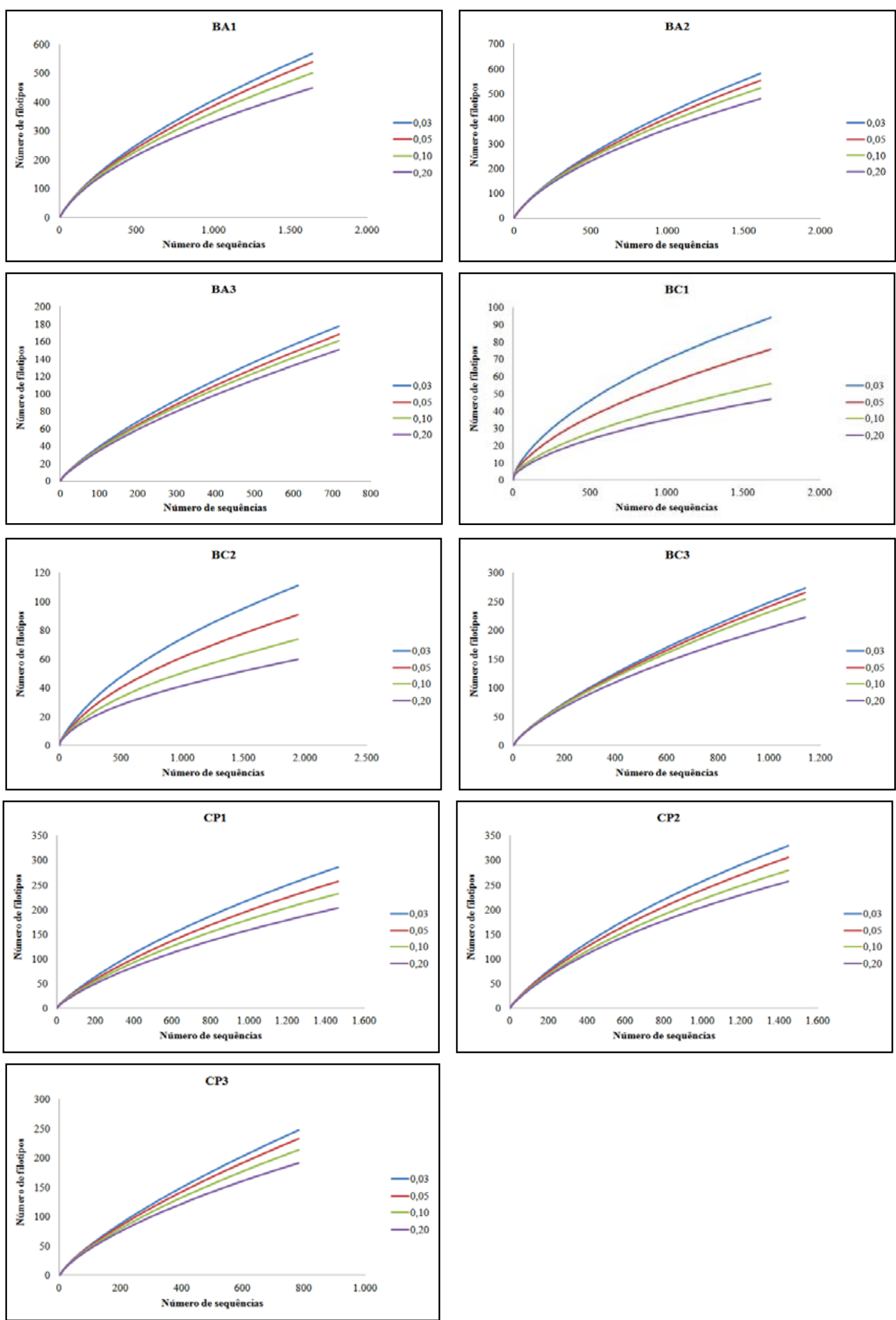

Ordenada: número de OPFs; Abscissa: número de sequências analisadas. 
A comparação da estrutura da comunidade por métodos baseados em OPFs foi realizada para quantificar a riqueza compartilhada observada (sharedsobs) e estimada (sharedace e sharedchao) entre as amostras. Os índices de beta-diversidade foram calculados entre as amostras de sedimento dos três manguezais analisados para o cutoff de 0,20. Os resultados estão apresentados na Tabela 23.

Observa-se nos dados obtidos com a análise de beta-diversidade que os índices de riqueza compartilhada (Sharedsobs, Sharedace e Sharedchao) foram maiores entre os manguezais BA e CP do que entre BA e BC. Analisando a riqueza compartilhada entre os pontos amostrais, verifica-se que os maiores índices foram os de Bertioga Antropizado, especialmente quando se comparou os pontos BA1 com BA2. Outra consideração importante é que para todos os manguezais os pontos P1 e P2 compartilham mais OTUs entre si do que com o ponto P3, da mesma forma como o observado para o gene 16S rRNA.

A similaridade dos membros da comunidade, quanto a sua estrutura, foi medida através dos coeficientes de abundância de Jaccard (Jclass) e Theta de Yue-Clayton (Thetayc). De acordo com estes coeficientes os pontos amostrais BA1 e BA2 foram os que apresentaram maior similaridade entre si com relação às comunidades microbianas.

Tabela 22. Índices de beta-diversidade calculados entre as amostras dentro de cada manguezal para o cutoff de 0,20.

\begin{tabular}{ccccccc}
\hline \multirow{2}{*}{$\begin{array}{c}\text { Amostras } \\
\text { comparadas }\end{array}$} & \multicolumn{5}{c}{ Índices de beta-diversidade* } \\
\cline { 3 - 7 } \multicolumn{2}{c}{} & Sharedsobs & Sharedace & Sharedchao & Jclass & thetayc \\
\hline BA & BC & 123 & 287 & 266 & 0,120 & 0,193 \\
BA & CP & $\mathbf{1 9 5}$ & $\mathbf{3 5 8}$ & $\mathbf{3 6 4}$ & $\mathbf{0 , 1 7 0}$ & $\mathbf{0 , 2 4 4}$ \\
BC & CP & 117 & 259 & 303 & 0,164 & 0,695 \\
BA1 & BA2 & $\mathbf{1 8 5}$ & $\mathbf{3 4 0}$ & $\mathbf{3 1 3}$ & $\mathbf{0 , 2 4 9}$ & $\mathbf{0 , 4 0 1}$ \\
BA1 & BA3 & 65 & 294 & 197 & 0,121 & 0,040 \\
BA2 & BA3 & 66 & 392 & 220 & 0,117 & 0,065 \\
BC1 & BC2 & 15 & 25 & 30 & 0,163 & 0,071 \\
BC1 & BC3 & 7 & 5 & 10 & 0,027 & 0,011 \\
BC2 & BC3 & 11 & 21 & 22 & 0,040 & 0,032 \\
CP1 & CP2 & 90 & 165 & 165 & 0,243 & 0,926 \\
CP1 & CP3 & 54 & 136 & 174 & 0,158 & 0,447 \\
CP2 & CP3 & 48 & 69 & 90 & 0,120 & 0,544 \\
\hline
\end{tabular}

*Sharedsobs: número de OTUs compartihadas observadas; Sharedace: índice de ACE compartilhado; Sharedchao: índice de Chao1 compartilhado; Jclass: coeficiente de similaridade de Jaccard; Sorclass: coeficiente de similaridade de Sorensen; Jabund: abundância baseada no coeficiente de Jaccard; Thetayc: coeficiente de similaridade theta de Yue-Clayton. 
Com o intuito de melhor representar os resultados das análises de riqueza compartilhada entre as amostras, também foram gerados diagramas de Venn para verificar as intersecções e peculiaridades de cada ambiente, identificando o número de OPFs exclusivas e compartilhadas entre os pontos de cada manguezal no cutoff de 0,20 (Figura 45).

Figura 45. Diagrama de Venn representando o número de OPFs únicas e compartilhadas entre as amostras de sedimento de cada manguezal. Valor de cutoff $=0,20$.

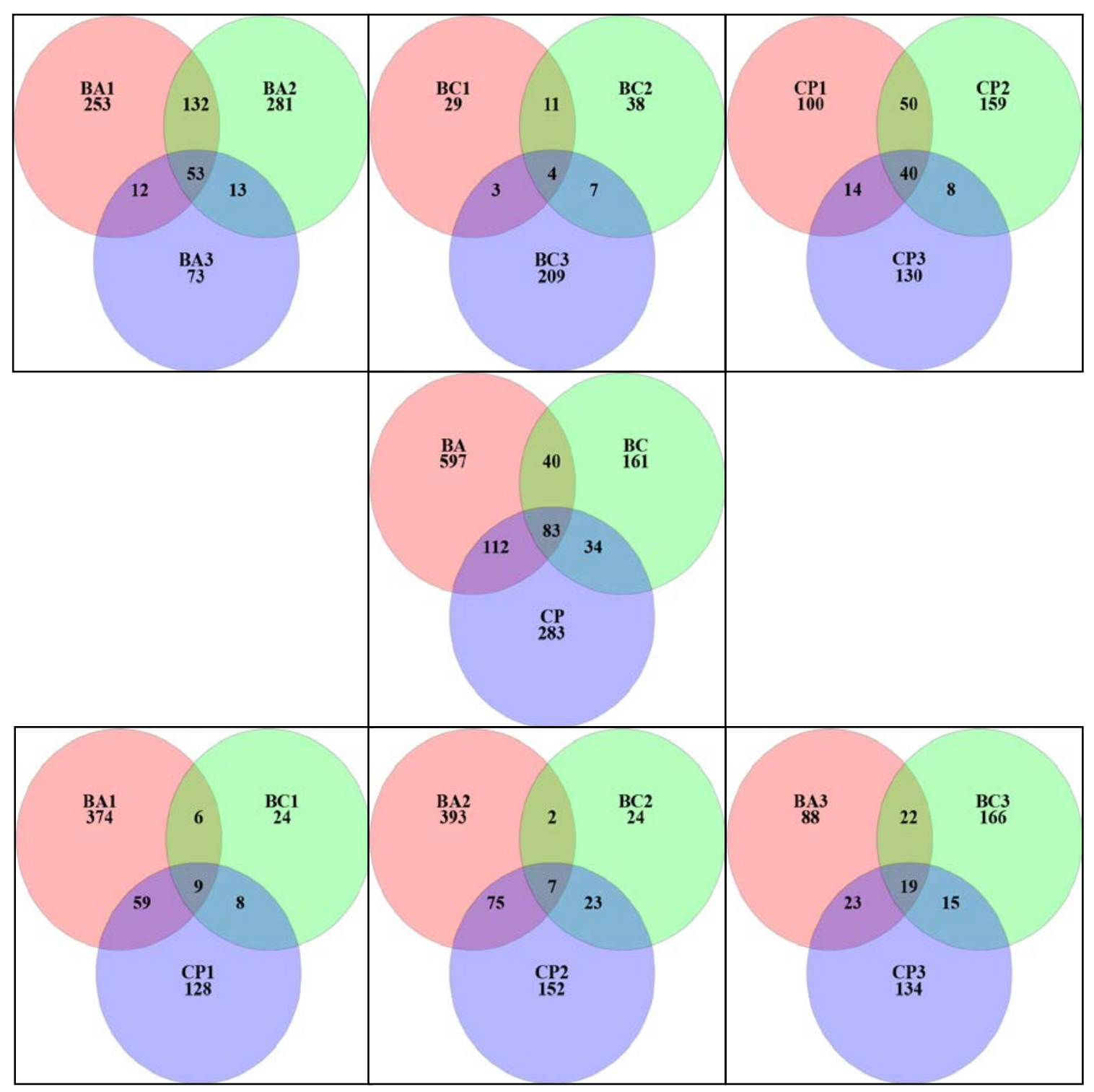

Através da análise dos diagramas foi possível confirmar uma maior quantidade de OPFs únicas nas sequências obtidas no manguezal de Bertioga Antropizado (n=597) em comparação com os demais manguezais amostrados. Também fica evidente que os pontos amostrais P1 e P2 compartilham mais seqüências entre si, do que com o ponto P3 em todos os 
manguezais, assim como BA compartilha mais OPFs com CP do que com BC, como já mencionado anteriormente.

A beta diversidade também foi estimada através do teste de hipótese Libshuff e os resultados desse teste estão apresentados na Tabela 24. Observa-se que o p-value foi significativo para a maior parte dos pares de amostras analisados. Mas o teste revelou que o manguezal BC é uma subamostragem do manguezal CP e que no manguezal CP tem-se que CP1 é subamostragem tanto de CP2 quanto de CP3. Cabe mais uma vez ressaltar que os testes baseados em hipóteses conseguem detectar diferenças estatisticamente significativas, mas não necessariamente representam uma diferença ecologicamente significativa.

Tabela 23. Teste de hipótese Libshuff entre as amostras dos três manguezais, sob um cutoff de 0,20 .

\begin{tabular}{cccc}
\hline $\begin{array}{c}\text { Amostras } \\
\text { Comparadas }\end{array}$ & dCXYScore & $\begin{array}{c}\text { Significância } \\
(\boldsymbol{p} \text {-value })\end{array}$ & Resultado $^{\mathbf{a}}$ \\
\hline BA-BC & 0.05463207 & $<0.0001$ & Significativo \\
BC-BA & 0.00058660 & $<0.0001$ & Significativo \\
BA-CP & 0.01749980 & $<0.0001$ & Significativo \\
CP-BA & 0.00458040 & $<0.0001$ & Significativo \\
BC-CP & $\mathbf{0 . 0 0 0 1 1 1 3 6}$ & $\mathbf{0 . 0 0 6 8}$ & Não significativo \\
CP-BC & 0.01099647 & $<0.0001$ & Significativo \\
BA1-BA2 & 0.00682147 & $<0.0001$ & Significativo \\
BA2-BA1 & 0.00320260 & $<0.0001$ & Significativo \\
BA1-BA3 & 0.04795138 & $<0.0001$ & Significativo \\
BA3-BA1 & 0.00634260 & $<0.0001$ & Significativo \\
BA2-BA3 & 0.05098848 & $<0.0001$ & Significativo \\
BA3-BA2 & 0.00995646 & $<0.0001$ & Significativo \\
BC1-BC2 & 0.00034172 & $<0.0001$ & Significativo \\
BC2-BC1 & 0.02606894 & $<0.0001$ & Significativo \\
BC1-BC3 & 0.00080718 & $<0.0001$ & Significativo \\
BC3-BC1 & 0.30061386 & $<0.0001$ & Significativo \\
BC2-BC3 & 0.00069011 & 0.0005 & Significativo \\
BC3-BC2 & 0.21235308 & $<0.0001$ & Significativo \\
CP1-CP2 & $\mathbf{0 . 0 0 0 0 1 3 5 8}$ & $\mathbf{0 . 7 0 1 4}$ & Não significativo \\
CP2-CP1 & 0.00132789 & $<0.0001$ & Significativo \\
CP1-CP3 & $\mathbf{0 . 0 0 1 6 7 2 9 9}$ & $\mathbf{0 . 0 0 3 7}$ & Não significativo \\
CP3-CP1 & 0.04562410 & $<0.0001$ & Significativo \\
CP2-CP3 & 0.00724584 & $<0.0001$ & Significativo \\
CP3-CP2 & 0.05254808 & $<0.0001$ & Significativo \\
\hline
\end{tabular}

${ }^{1}$ Significativo se $\mathrm{p}<0,00083$ 
Um dos grandes desafios de trabalhos envolvendo dados provenientes de metagenoma é a análise de grande quantidade de dados (SILVA, 2011). Inicialmente foram feitas tentativas de construção e árvores filogenéticas utilizando sequências representativas de cada cluster gerado neste estudo, sem, entretanto, obter-se resultados confiáveis, uma vez que as sequências são muito diversas e os valores de bootstrap muito baixos.

De forma geral as análises filogenéticas com as sequências do gene $b p h$ obtidas a partir do pirosequenciamento apresentaram grupos bastante heterogêneos, distribuídos entre 66 gêneros microbianos. Muitas sequências não foram aqui analisadas para reduzir o tempo e trabalho computacional, portanto genes novos podem existir nas amostras analisadas, porém estudos adicionais são necessários para confirmar esta hipótese.

Os resultados aqui apresentados sobre diversidade de genes funcionais nas amostras de sedimento dos manguezais produziram informações importantes acerca dos micro-organismos envolvidos nos processos metabólicos relacionados à biodegradação de compostos aromáticos, demonstrando uma maior diversidade de genes $\alpha$-ARHD na área impactada por petróleo (BC), mas para o gene bph os maiores índices de diversidade foram obtidos para o manguezal que sofre influência antrópica (BA), demonstrando a resposta das comunidades microbianas em função dos estímulos sofridos nestes ambientes.

A maior diversidade do gene bph detectada no manguezal de Bertioga Antropizado, bem como a maior concentração do bifenilo na amostra de sedimento BA1 nos leva a questionar sobre a origem do bifenilo ali encontrado, podendo tratar-se de uma ocorrência natural ou o ambiente pode estar sofrendo uma possível contaminação por este composto via descarga de resíduos que ocorrem no ambiente, portanto um aprofundamento na análise sobre os efeitos deletérios causados pelos efluentes de origem antrópica nesse ambiente seriam de grande importância. 


\subsection{Microarranjos de DNA - GeoChip}

A riqueza dos genes funcionais encontrada em nosso estudo, que consiste no número de sondas de genes com hibridização positiva considerando o total de amostras analisadas, está apresentada na Tabela 25. De um total de 83.992 sondas relacionadas a genes funcionais presentes na lâmina de GeoChip, foram detectados 30.403 genes em pelo menos um ponto das amostras dos manguezais.

Tabela 24. Número de genes dos diferentes grupos de processos funcionais detectados nas amostras de sedimentos dos manguezais.

\begin{tabular}{lc}
\hline \multicolumn{1}{c}{ Grupo de Processos Funcionais } & Número de Genes Detectados \\
\hline Ciclo do Carbono & 3.530 \\
Ciclo do Enxofre & 1.306 \\
Ciclo do Fósforo & 432 \\
Ciclo do Nitrogênio & 2.442 \\
Degradação de compostos orgânicos & 6.867 \\
Estresse & 6.073 \\
Genes de bacteriófagos & 178 \\
Marcador filogenético gyrB & 594 \\
Processos energéticos & 321 \\
Resistência a antibióticos & 1.093 \\
Resistência a metais & 3.395 \\
Virulência & 1.101 \\
Outros & 3.071 \\
\hline
\end{tabular}

30.403

O emprego da técnica do GeoChip possibilitou avaliar, de forma qualitativa e quantitativa, a diversidade de genes presentes nas áreas de estudo. A Tabela 26 e Figuras 46 e 47 apresentam os dados totais de riqueza obtidos por ponto amostral. Os valores apresentados correspondem à média entre 3 amostras (análise por ponto amostral) e 9 amostras (análise por manguezal). Foram detectados entre 11.787 (CP3) e 24.050 (BC3) genes nessas amostras. A diferença entre a média do número de genes entre pontos amostrais foi significativa (ANOVA; $\mathrm{p}<0,001$ ), sendo que os pontos BC3 e BC2 tiveram um número significativamente maior de riqueza de genes que os demais. 
Tabela 25. Número de sondas de genes relacionados a diferentes processos que apresentaram hibridização positiva nas amostras analisadas.

\begin{tabular}{|c|c|c|c|c|c|c|c|c|c|c|}
\hline \multirow[b]{2}{*}{ Grupo de Processos Funcionais } & \multirow[b]{2}{*}{ Processos Funcionais } & \multicolumn{3}{|c|}{ Bertioga Antropizado } & \multicolumn{3}{|c|}{ Bertioga Contaminado } & \multicolumn{3}{|c|}{ Cananéia Preservado } \\
\hline & & BA1 & BA2 & BA3 & BC1 & BC2 & BC3 & CP1 & CP2 & CP3 \\
\hline \multirow[t]{5}{*}{ Ciclo do Carbono } & Degradação de carbono & 1.107 & 1.154 & 1.509 & 1.423 & 1.964 & 2.110 & 1.360 & 1.216 & 1.066 \\
\hline & Fixação de carbono & 257 & 255 & 349 & 333 & 455 & 511 & 294 & 261 & 233 \\
\hline & Oxidação de metano & 19 & 23 & 29 & 29 & 37 & 45 & 27 & 22 & 22 \\
\hline & Produção de metano & 15 & 13 & 22 & 18 & 44 & 51 & 22 & 18 & 13 \\
\hline & Acetogênese & 11 & 11 & 14 & 12 & 17 & 19 & 16 & 14 & 13 \\
\hline Ciclo do Enxofre & & 454 & 475 & 633 & 598 & 873 & 984 & 565 & 514 & 433 \\
\hline Ciclo do Fósforo & & 183 & 185 & 235 & 215 & 297 & 328 & 223 & 193 & 175 \\
\hline \multirow[t]{7}{*}{ Ciclo do Nitrogênio } & Amonificação & 143 & 142 & 178 & 174 & 221 & 244 & 157 & 138 & 132 \\
\hline & Anammox & 5 & 5 & 4 & 4 & 3 & 4 & 4 & 5 & 4 \\
\hline & Nitrificação & 166 & 172 & 211 & 204 & 266 & 294 & 198 & 177 & 169 \\
\hline & Desnitrificação & 332 & 356 & 497 & 484 & 690 & 776 & 426 & 361 & 313 \\
\hline & Fixação de nitrogênio & 175 & 166 & 206 & 196 & 276 & 298 & 191 & 174 & 164 \\
\hline & Redução assimilatória do nitrogênio & 66 & 66 & 93 & 86 & 119 & 132 & 80 & 68 & 60 \\
\hline & Redução dissimilatória do nitrogênio & 60 & 66 & 85 & 84 & 116 & 126 & 76 & 71 & 63 \\
\hline \multirow[t]{5}{*}{ Degradação de compostos orgânicos } & Hidrocarbonetos aromáticos & 2.049 & 2.106 & 2.895 & 2.776 & 3.827 & 4.240 & 2.439 & 2.152 & 1.880 \\
\hline & Outros hidrocarbonetos & 241 & 253 & 333 & 313 & 449 & 483 & 298 & 259 & 227 \\
\hline & Solvente clorados & 100 & 101 & 132 & 128 & 161 & 176 & 121 & 108 & 94 \\
\hline & Pesticidas & 82 & 87 & 107 & 106 & 142 & 159 & 98 & 85 & 77 \\
\hline & Herbicidas & 243 & 248 & 352 & 331 & 441 & 481 & 294 & 245 & 228 \\
\hline \multirow{9}{*}{ Estresse } & Fatores sigma & 513 & 527 & 710 & 687 & 906 & 994 & 593 & 515 & 464 \\
\hline & Limitação de Nitrogênio & 192 & 194 & 247 & 246 & 326 & 356 & 232 & 207 & 187 \\
\hline & Limitação de Fósforo & 647 & 659 & 820 & 771 & 1.001 & 1.086 & 739 & 656 & 635 \\
\hline & Limitação de Oxigênio & 147 & 152 & 187 & 180 & 229 & 252 & 166 & 152 & 138 \\
\hline & Stress por oxigênio & 552 & 569 & 760 & 730 & 1.004 & 1.108 & 653 & 576 & 526 \\
\hline & Choque térmico & 171 & 173 & 236 & 223 & 317 & 348 & 199 & 167 & 158 \\
\hline & Stress osmótico & 58 & 63 & 80 & 74 & 102 & 108 & 68 & 61 & 60 \\
\hline & Radiação & 123 & 119 & 164 & 147 & 229 & 255 & 142 & 121 & 117 \\
\hline & Outros & 83 & 81 & 99 & 99 & 125 & 131 & 84 & 80 & 79 \\
\hline Genes de bacteriófagos & & 71 & 73 & 90 & 83 & 110 & 121 & 83 & 73 & 71 \\
\hline Marcador filogenético gyrB & & 226 & 236 & 298 & 284 & 406 & 447 & 269 & 230 & 217 \\
\hline Processos energéticos & & 126 & 126 & 161 & 212 & 159 & 244 & 156 & 135 & 124 \\
\hline Resistência a antibióticos & & 445 & 455 & 595 & 563 & 768 & 843 & 537 & 469 & 437 \\
\hline Resistência a metais & & 1.392 & 1.426 & 1.873 & 1.780 & 2.449 & 2.655 & 1.656 & 1.453 & 1.295 \\
\hline Virulência & & 497 & 496 & 629 & 594 & 783 & 848 & 564 & 521 & 477 \\
\hline \multirow[t]{2}{*}{ Outros } & & 1.441 & 1.528 & 1.908 & 1.800 & 2.562 & 2.792 & 1.845 & 1.636 & 1.433 \\
\hline & & 12.393 & 12.760 & 16.739 & 15.986 & 21.876 & 24.050 & 14.875 & 13.135 & 11.787 \\
\hline
\end{tabular}


Ao analisar a Tabela 26 um fator importante a se considerar é que a lâmina do GeoChip não apresenta o mesmo número de sondas para todos os processos funcionais, e estas sondas são mais numerosas para os genes associados a estresse, degradação orgânica e ciclo do carbono, levando a uma maior detecção destes genes nas amostras analisadas. Mas, dentro dos grupos de processos funcionais presentes no GeoChip, genes relacionados aos ciclos do carbono, enxofre, fósforo e nitrogênio foram observados em todos os pontos amostrais dos manguezais analisados. A oxidação e geração de metano também foi reportada. Além disso, genes relacionados à remediação orgânica, estresse e resistência a metais foram detectados em maiores frequências.

Figura 46. Riqueza de genes funcionais nas amostras de sedimento dos manguezais analisados.

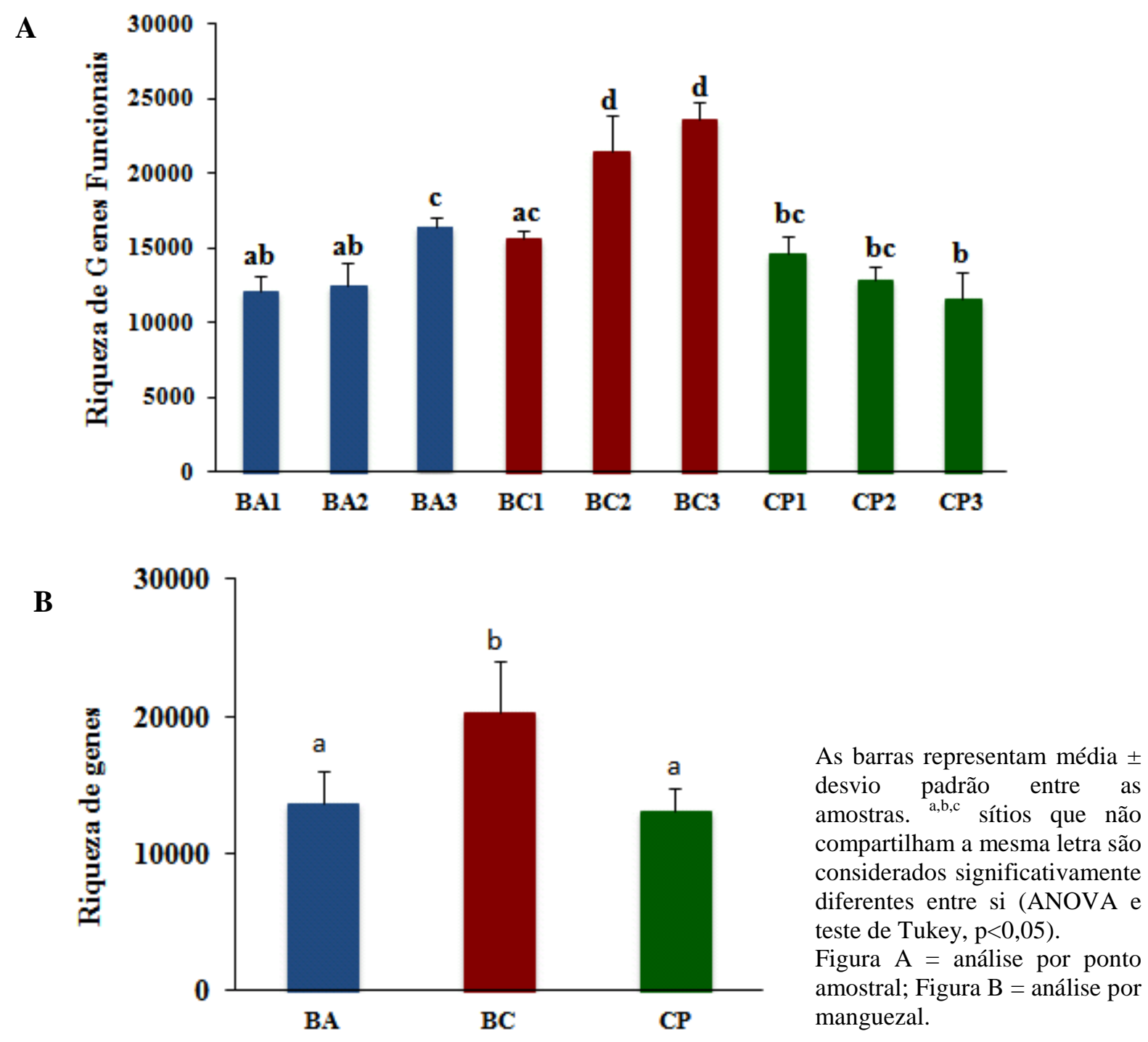


Figura 47. Riqueza de famílias de genes funcionais nas amostras de sedimento dos manguezais analisados.
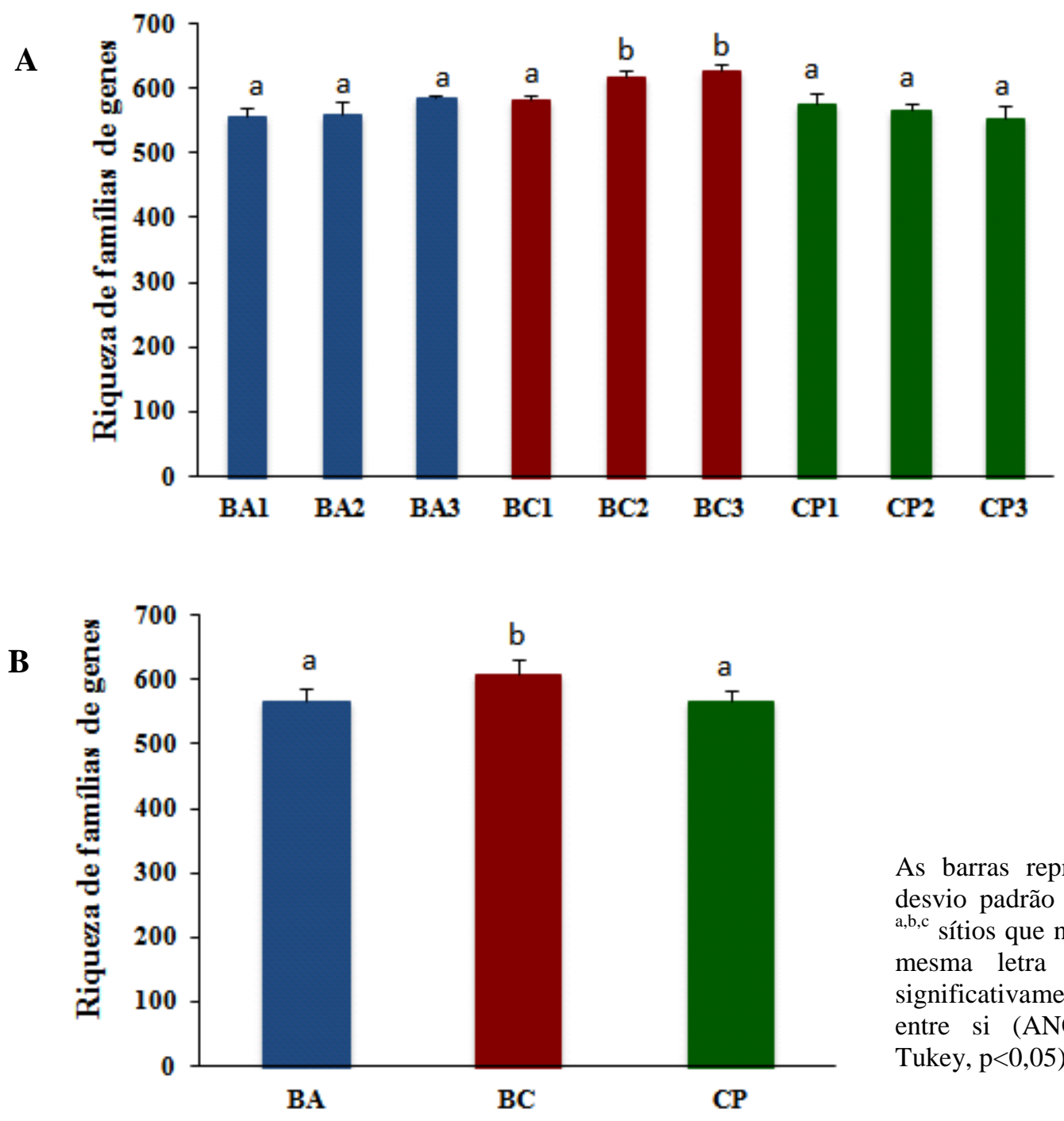

As barras representam média \pm desvio padrão entre as amostras. a,b,c sítios que não compartilham a mesma letra são considerados significativamente diferentes entre si (ANOVA e teste de Tukey, $\mathrm{p}<0,05)$.

Figura A = análise por ponto amostral; Figura B = análise por manguezal.

Em nosso trabalho os resultados do GeoChip indicaram que nas amostras de manguezal avaliadas, a riqueza de genes e de famílias de genes funcionais foi maior na área onde ocorreu o derramamento de petróleo, que foi significativamente diferente das demais. Também foi possível verificar pelos diagramas de Venn (Figura 48) que 53,57\% ( $n=16.288)$ dos genes são compartilhados entre os três manguezais e que o manguezal BC foi aquele que apresentou o maior número de sondas únicas de genes, correspondendo a 25,87\% do total. 
Figura 48. Diagramas de Venn apresentando o número de sondas únicas e compartilhadas entre os manguezais.

A

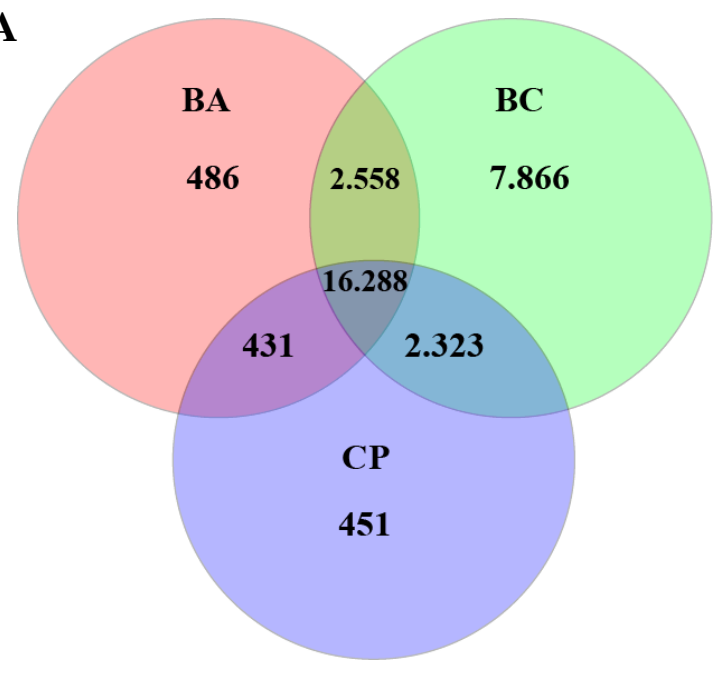

B

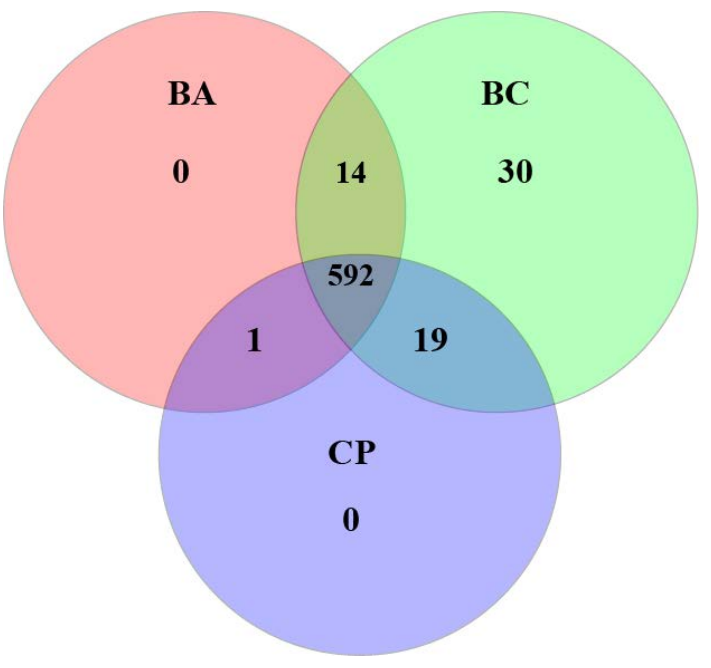

$\mathrm{A}=$ considerando as sondas de genes; $\mathrm{B}=$ considerando as famílias de genes.

Quando nos aprofundamos nos resultados das Figuras 46 e 47 constata-se que os pontos BC2 e BC3 foram aqueles que apresentaram o maior número de sondas de genes e de famílias de genes e também, e de acordo com os resultados mencionados anteriormente, esses pontos amostrais foram aqueles que possuem as maiores concentrações de HPAs totais e uma maior diversidade do gene $\alpha$-ARHD. Já os resultados do pirosequenciamento para o gene $16 \mathrm{~S}$ rRNA demonstraram que esses pontos apresentaram menor número de OTUs e também os menores índices de riqueza e estimativas de diversidade quando comparados com a área preservada. Uma explicação para tais resultados é que a contaminação com o petróleo nestes pontos promoveu um decréscimo na diversidade microbiana em termos de abundância de espécies (OTUs), devido à extinção de espécies não adaptadas ao estresse imposto, mas ao mesmo tempo essa contaminação ocasionou o enriquecimento gênico da comunidade que ali conseguiu se estabelecer e se tornou versátil metabolicamente, possivelmente por conta das transferências horizontais de genes que foram estabelecidas ao longo dos anos, como já mencionado anteriormente.

Tal hipótese fica mais evidente ao analisarmos a Figura 49 que mostra a caracterização dos pontos amostrais dentro de cada manguezal com relação à riqueza de genes associados a cada processo funcional ali detectado. 
Figura 49. Riqueza de processos funcionais detectados nas amostras de sedimento dos manguezais analisados.

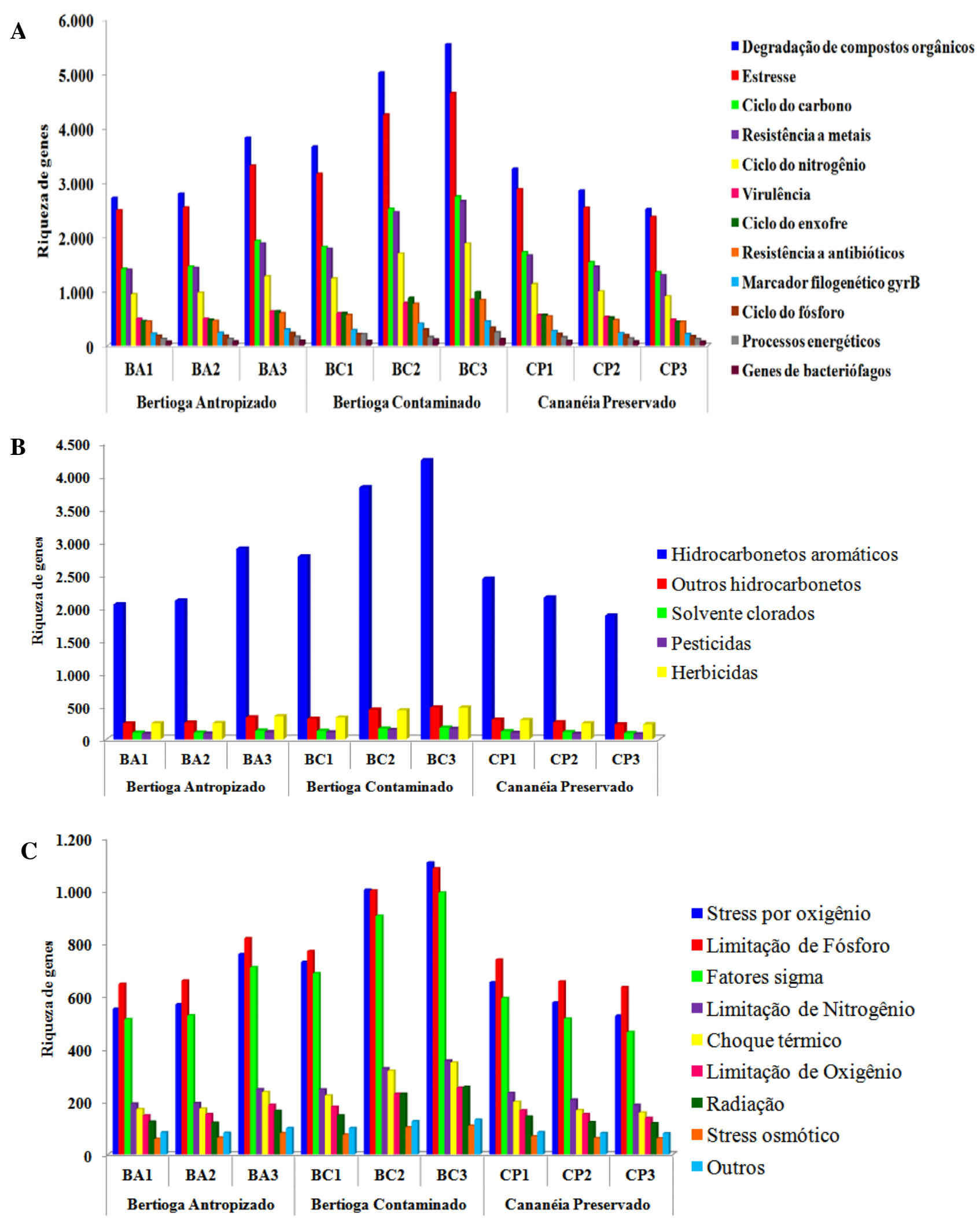

(A) Grupos de processos funcionais; (B) Genes relacionados à degradação de compostos orgânicos e (C) Genes relacionados a processos de estresse. 
Nesta ilustração fica claro que os pontos amostrais BC3 e BC2 apresentam uma maior riqueza de genes que os demais, especialmente com relação aos processos de degradação de compostos orgânicos, estresse, ciclo do carbono e resistência a metais.

Na Figura 49-B é possível observar que a maior frequência de genes relacionados ao processo funcional de degradação de compostos orgânicos está associada à degradação de hidrocarbonetos aromáticos para todas as amostras. Já na Figura 49-C observa-se que a maioria dos genes associados a fatores de estresse estão relacionados à presença de oxigênio, limitação de fósforo e fatores sigma, responsáveis pela transcrição de genes envolvidos na resposta geral ao estresse e fase estacionária de crescimento.

Com os resultados do GeoChip também foi possível avaliar como as amostras estudadas se agrupam considerando a abundância de genes (além da presença, a intensidade do sinal produzido por cada gene foi aqui considerado) para cada processo funcional. Para este fim foi construído um dendograma de distância euclidiana entre as amostras, baseado nos perfis de coloração de um mapa de cores que reflete a abundância de genes de cada processo funcional. Como pode ser visto na Figura 50, de forma geral houve uma separação entre as amostras dos três manguezais.

A análise de agrupamento também deixa evidente que, com relação à abundância de genes funcionais, os manguezais de Bertioga estão mais próximos entre si do que com Cananéia. Além disso, há uma maior associação das amostras do manguezal BC com o processo funcional de degradação de compostos orgânicos, como já observado para os dados de riqueza.

Na análise de abundância verifica-se que o manguezal BC esteve associado aos processos de degradação de compostos orgânicos, lixiviação, genes de bacteriófagos, utilização de fósforo, genes de patógenos do solo e processos energéticos. O manguezal BA correlacionou-se com resistência a metais e virulência, enquanto o manguezal CP a associação se deu com genes relacionados ao ciclo do carbono, estresse, ciclo do nitrogênio, ciclo do enxofre, virulência, benefícios para o solo e resistência a antibióticos.

É importante lembrar que o GeoChip avalia apenas sequências de genes já conhecidas e que já foram depositadas no banco de dados. Um ambiente pouco estudado em termos metabólicos, como os manguezais, pode ter sua diversidade subestimada, devido à falta de cobertura de seus genes. Apesar disto, a técnica se mostrou eficaz para detectar diferenças dentro dos ambientes analisados. 
Figura 50. Dendograma de cores com análise de agrupamento baseada na abundância de genes funcionais detectada pelo GeoChip.

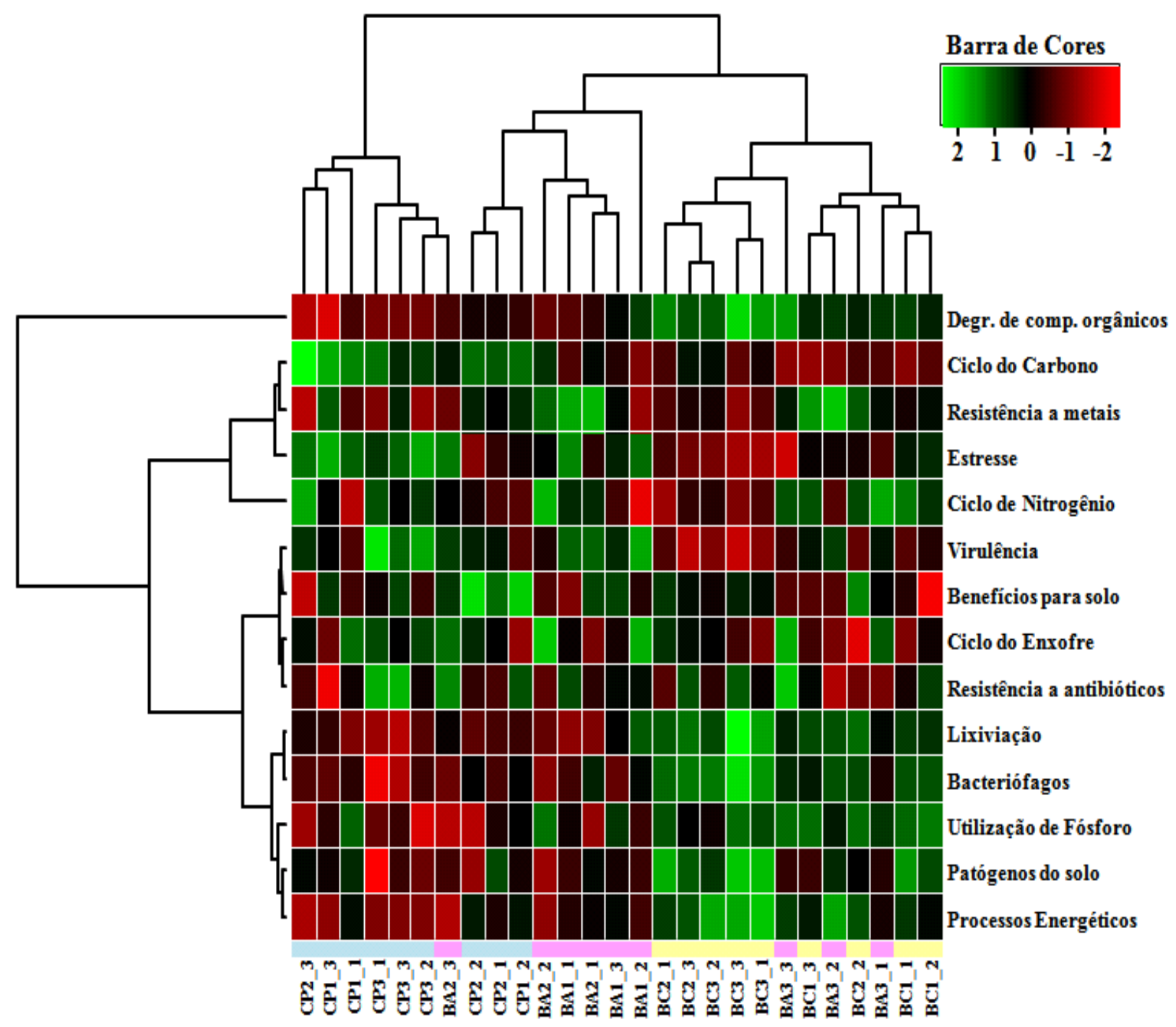

As colunas representam as amostras e as linhas representam os processos funcionais. A intensidade das cores é proporcional à abundância de genes para cada processo funcional em cada amostra.

Em nosso estudo a análise de NMDS foi utilizada para verificar a estrutura funcional e similaridade entre as comunidades de cada manguezal, como pode ser observado na Figura 51. Observa-se nesta figura que os houve uma nítida separação por manguezais. Outra observação importante é que os pontos BC2 e BC3 distanciaram dos demais, o que indica uma baixa similaridade entre a comunidade destes pontos em relação aos demais. Também é possível observar que o manguezal BA apresenta uma comunidade mais similar ao ponto BC1 do manguezal contaminado, como já demonstrado pela análise de agrupamento baseada na abundância dos genes. 
Figura 51. Ordenação em escala multidimensional não métrica (NMDS) da estrutura funcional das comunidades microbianas dos sedimentos dos manguezais analisados.

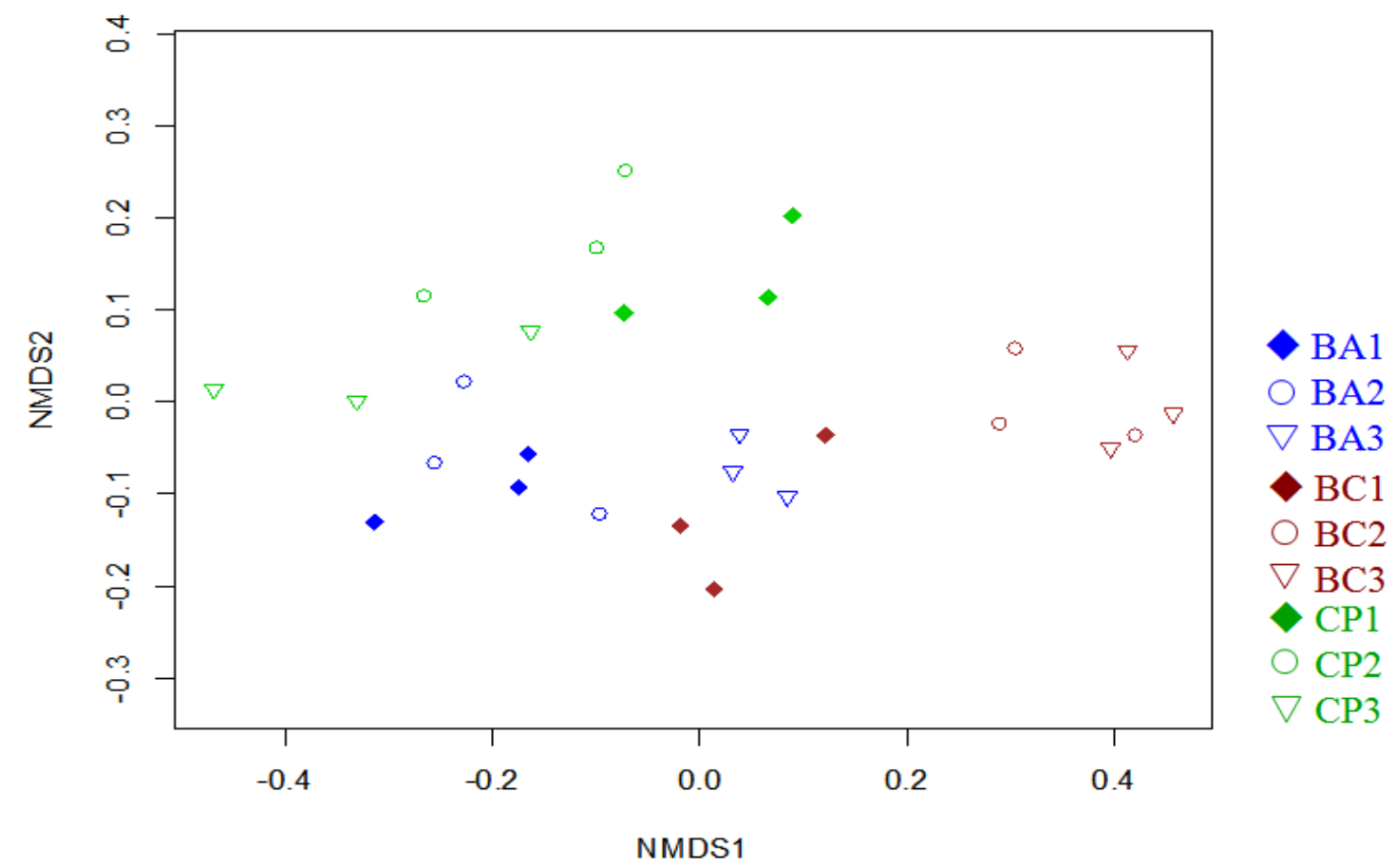

Índice de dissimilaridade: Bray-Curtis. Stress= 0,07

O primeiro trabalho a utilizar a técnica de microarranjos para análise de genes funcionais em amostras de manguezais no Brasil foi realizado por Paes (2008) que trabalhou com duas amostras de solo da baía de Todos os Santos, sendo um sítio de amostragem localizado dentro de uma região de complexo petrolífero e o outro considerado pouco contaminado por petróleo. Para este estudo a referida autora utilizou o GeoChip 2.0 que apresentava 24.243 sondas. Os dados obtidos indicaram 184 sequências gênicas na área contaminada e 233 na área preservada. Os maiores números de genes detectados nas amostras foram associados ao processo de remediação orgânica e totalizaram 40,76\% e 42,50\% dos genes detectados na área contaminada e preservada, respectivamente. Ao contrário de nossos resultados a referida autora, além de verificar maior número de genes associados à degradação de compostos orgânicos no ambiente preservado, também verificou, pelo uso da técnica de TRFLP, maior diversidade microbiana na área contaminada.

A técnica de GeoChip também foi utilizada por Paula (2012) para análise da diversidade e estrutura funcional de comunidades microbianas em solos da Amazônia em resposta a mudanças na forma de uso do solo. Os resultados obtidos indicaram uma riqueza de 66.388 
genes e mostraram que a conversão da floresta para pastagem causou alteração da estrutura funcional da comunidade e redução significativa da diversidade de genes funcionais.

É importante mencionar que a riqueza de genes funcionais revela a diversidade metabólica contida no genoma de uma comunidade. Embora a presença do gene não signifique que a função a ele relacionada esteja sendo executada, uma maior riqueza funcional indica maior versatilidade metabólica em potencial (PAULA, 2012).

Sabemos que um grande número de fatores físicos, químicos e biológicos pode influenciar na atividade dos micro-organismos no solo e na estrutura da comunidade microbiana de um determinado ambiente. Em nosso trabalho escolhemos os atributos físicoquímicos, a concentração de HPAs e a caracterização genética e funcional dos microorganismos na tentativa de encontrar correlações com as alterações sofridas pela comunidade microbiana que realiza sua atividade biológica a uma profundidade de $10 \mathrm{~cm}$ do sedimento dos manguezais analisados. Tentamos aqui utilizar um conjunto de diferentes abordagens taxonômicas e funcionais para retratar os efeitos crônicos da poluição com petróleo, que muitas vezes são de difícil diagnóstico e são mascarados pela dinâmica de recuperação do ambiente.

Em nosso estudo, diante de todos os resultados obtidos e dos índices ecológicos aplicados é possível sugerir que houve alteração na estrutura taxonômica e funcional dos manguezais impactados, especialmente daquele em que houve contaminação com petróleo. Possivelmente a alteração na comunidade levou a um menor desempenho reprodutivo de alguns grupos ou desvantagens na competição por degradação das novas fontes do contaminante presente na área (AL-SAYED et al., 2005). Dessa forma, a teoria de substituição de espécies pode ter ocorrido, onde a diminuição populacional de um grupo resultou no surgimento de novos grupos ou no aumento de populações previamente existentes na área, levando a uma menor diversidade bacteriana, porém maior versatilidade metabólica das espécies presentes (BATTIN et al., 2007; LINDSTROM et al., 1999).

Vale aqui considerar que apesar do crescente empenho científico para tentar reverter o quadro de degradação dos ecossistemas de manguezais, ainda são poucos os registros de resultados efetivamente bem-sucedidos na remediação in situ de áreas de manguezais impactadas por hidrocarbonetos. Tem-se, portanto, uma demanda na produção e aplicação de conhecimento neste setor. Faz-se necessária e urgente a geração de dados que ajudem a promover a inversão desta realidade. A riqueza genética destes ecossistemas representa um enorme potencial biotecnológico, que deve ser protegido, garantindo sua sustentabilidade a médio e longo prazo. 


\section{CONCLUSÕES}

A combinação das diferentes técnicas utilizadas neste estudo possibilitou acessar com profundidade a diversidade microbiana existente nas amostras de sedimento dos três manguezais aqui analisados. Os resultados obtidos propiciaram inferências importantes sobre tais ambientes:

$\checkmark$ Os manguezais de Bertioga (BA e BC) apresentam características físico-químicas e de processos funcionais mais semelhantes entre si do que com Cananéia;

$\checkmark$ Ainda existem resquícios de HPAs de origem petrogênica nos pontos BC2 e BC3 mesmo após 29 anos decorridos do derramamento, e este fato é um importante indicador dos efeitos crônicos da contaminação causada pelo petróleo;

A aplicação de primers degenerados permitiu uma caracterização do gene $\alpha$-ARHD nas amostras de sedimentos dos manguezais, indicando uma maior diversidade no ambiente previamente contaminado com petróleo, e possibilitando a detecção de genes relacionados à produção de enzimas envolvidas na degradação de bifenilo, benzeno, naftaleno, dibenzofurano e fenilpropanoato e evidenciando a presença de gêneros bacterianos como Pseudomonas, Rhodococcus, Burkholderia e Nocardioides com potencial genético para a degradação de diferentes hidrocarbonetos aromáticos;

$\checkmark$ A maior diversidade de enzimas ARHDs observadas na amostra BC3 está associada à alta variabilidade de substratos que foram inseridos naquele ponto, devido à contaminação por petróleo e seus subprodutos orgânicos;

$\checkmark$ Os ambientes contaminado e antropizado apresentaram maior número de microorganismos isolados a partir do enriquecimento com hidrocarboneto aromático, demonstrando a presença dos gêneros Agromyces, Bacillus, Cellulomonas, Enterobacter, Lysinibacillus, Microbacterium, Ochrobactrum, Pseudomonas e Serratia;

Os resultados da PCR quantitativa para os genes 16S rRNA e $\alpha$-ARHDs possibilitaram comprovar que a maior concentração de hidrocarbonetos totais, bem como a maior 
diversidade dos genes $\alpha$-ARHDs, também está associada a uma maior abundância deste gene nos pontos amostrais previamente contaminados com petróleo;

Os dados gerados a partir do pirosequenciamento para o gene 16S rRNA nos propiciaram verificar diferenças importantes na composição das comunidades microbianas destes três ambientes, sendo observada uma maior diversidade bacteriana no ambiente preservado e um aumento da classe Alphaproteobacteria no ambiente impactado;

As sequências do gene bph mostraram-se relacionadas aos gêneros Pseudomonas, Rhizobium, Rhodococcus, Mycobacterium, Microbacterium e Burkholderia. Uma maior diversidade do gene bph detectada no manguezal BA, bem como a maior concentração do bifenilo nas amostras de sedimento deste ambiente nos leva a questionar sobre uma possível contaminação por este composto via descarga de resíduos que ali ocorrem;

$\checkmark$ E finalmente o emprego da técnica de GeoChip nos possibilitou observar que nas amostras de manguezal avaliadas, a riqueza de genes foi alterada na área onde ocorreu o derramamento de petróleo (BC2 e BC3), especialmente pelo aumento de genes associados à biodegradação de compostos aromáticos.

Diante do exposto, confirma-se nossa hipótese inicial de que a contaminação por petróleo no sedimento do manguezal de Bertioga alterou a estrutura da comunidade bacteriana autóctone, favorecendo as comunidades de bactérias biodegradadoras de hidrocarbonetos e consequentemente acarretando a redução na diversidade da população bacteriana total. 


\section{REFERÊNCIAS}

ABESSA, D. M. S. Avaliação da qualidade de sedimento do sistema estuarino de Santos, SP, Brasil. 2002. 290 f. Tese (Doutorado em Oceanografia Biológica) - Instituto Oceanográfico, Universidade de São Paulo, São Paulo, 2002.

ABRAHAM, W. R. Microbial degradation of polychlorinated biphenyls (PCBs) in the environment. In: SINGH, V. P.; STAPLETON, R. D. (Ed.). Biotransformations: bioremediation technology for health and environmental protection. Amsterdam: Elsevier, 2002. v. 36. p. 29-67.

AHMED, I.; YOKOTA, A.; YAMAZOE, A.; FUJIWARA, T. Proposal of Lysinibacillus boronitolerans gen. nov. sp. nov., and transfer of Bacillus fusiformis to Lysinibacillus fusiformis comb. nov. and Bacillus sphaericus to Lysinibacillus sphaericus comb. nov. International Journal of Systematic and Evolutionary Microbiology, v. 57, p. 1117-1125, 2007.

AHN, Y.; SANSEVERINO, J.; SAYLER, G. S. Analyses of polycyclic aromatic hydrocarbon-degrading bacteria isolated from contaminated soils. Biodegradation, v. 10, p. 149-57, 1999.

AKEN, B. V.; CORREA, P. A.; SCHNOOR, J. L. Phytoremediation of polychlorinated piphenyls: new trends and promises. Environmental Science \& Technology, v. 44, p. 27672776, 2009.

AL-SAYED, H. A.; GHANEM, E. H.; SALEH, K. M. Bacterial community and some physico-chemical characteristics in a subtropical mangrove environment in Bahrain. Marine Pollution Bulletin, v. 50, p. 147-155, 2005.

ALCARAZ, L.; MORENO-HAGELSIEB, G.; EGUIARTE, L.; SOUZA, V.; HERRERAESTRELLA, L.; OLMEDO, G. Understanding the evolutionary relationships and major traits of Bacillus through comparative genomics. BMC Genomics, v. 11, p. 332, 2010.

ALMEIDA, R. Ecologia de manguezais. Dinâmica da serapilheira e funcionamento do ecossistema, Ilha do Cardoso, Cananéia, São Paulo. 2005. 182 f. Tese (Doutorado em Oceanografia Biológica) - Instituto Oceanográfico, Universidade de São Paulo, São Paulo, 2005.

ALONGI, D. M. Present state and future of the world's mangrove forests. Environmental Conservation, v. 29, p. 331-349, 2002.

ALTSCHUL, S. F.; GISH, W.; MILLER, W.; MEYERS, E. W.; LIPMAN, D. J. Basic local alignment search tool. Journal of Molecular Biology, v. 215, p. 403-410, 1990.

ANDREONI, V. GIANFREDA, L. Bioremediation and monitoring of aromatic-polluted habitats. Applied Microbiology and Biotechnology, v. 76, p. 287-308, 2007.

ANDREOTE, F. D.; JIMÉNEZ, D. J.; CHAVES, D.; DIAS, A. C. F.; LUVIZOTTO, D. M.; DINI-ANDREOTE, F.; FASANELLA, C. C.; LOPEZ, M. V.; BAENA, S.; TAKETANI, R. 
G.; MELO, I. S. The microbiome of Brazilian mangrove sediments as revealed by metagenomics. PLoS One, v. 7, p. e38600, 2012.

ANTIZAR-LADISLAO, B.; LOPEZ-REAL, J.; BECK, A. Bioremediation of polycyclic aromatic hydrocarbon (PAH)-contaminated waste using composting approaches. Critical Reviews in Environmental Science and Technology, v. 34, p. 249-289, 2004.

ARFI, Y.; BUEE, M.; MARCHAND, C.; LEVASSEUR, A.; RECORD, E. Multiple markers pyrosequencing reveals highly diverse and host-specific fungal communities on the mangrove trees Avicennia marina and Rhizophora stylosa. FEMS Microbiology Ecology, v. 79, p. 43344, 2012.

ARULAZHAGAN, P. VASUDEVAN, N. Biodegradation of polycyclic aromatic hydrocarbons by a halotolerant bacterial strain Ochrobactrum sp. VA1. Marine Pollution Bulletin, v. 62, p. 388-394, 2011.

ASSOCIAÇÃO BRASILEIRA DE NORMAS TÉCNICAS - ABNT. NBR 10004: classificação de resíduos sólidos Rio de Janeiro, 2004. 71 p.

ATLAS, R. M. Microbial degradation of petroleum hydrocarbons: an environmental perspective. Microbiological Reviews, v. 45, p. 180-209, 1981.

ATLAS, R. M. Petroleum biodegradation and oil spill bioremediation. Marine Pollution Bulletin, v. 31, p. 178-182, 1995.

AUSTRALIAN AND NEW ZEALAND ENVIRONMENT AND CONSERVATION COUNCIL - ANZECC/ARMCANZ. Australian and New Zealand Guidelines for fresh and marine water quality guidelines Artarmon, 2000. 314 p.

AVARRE, J.-C.; DE LAJUDIE, P.; BÉNA, G. Hybridization of genomic DNA to microarrays: a challenge for the analysis of environmental samples. Journal of Microbiological Methods, v. 69, p. 242-248, 2007.

BA, T.; ZHENG, M.; ZHANG, B.; LIU, W.; XIAO, K.; ZHANG, L. Estimation and characterization of PCDD/Fs and dioxin-like PCBs from secondary copper and aluminum metallurgies in China. Chemosphere, v. 75, p. 1173-1178, 2009.

BAHUGUNA, A.; LILY, M. K.; MUNJAL, A.; SINGH, R. N.; DANGWAL, K. Desulfurization of dibenzothiophene (DBT) by a novel strain Lysinibacillus sphaericus DMT7 isolated from diesel contaminated soil. Journal of Environmental Sciences, v. 23, p. 975982, 2011.

BAIRD, A. H.; BHALLA, R. S.; KERR, A. M.; PELKEY, N. W.; SRINIVAS, V. Do mangroves provide an effective barrier to storm surges? Proceedings of the National Academy of Sciences of the United States of America, v. 106, p. E111-E112, 2009.

BAKERMANS, C. MADSEN, E. L. Diversity of 16S rDNA and naphthalene dioxygenase genes from coal-tar-waste-contaminated aquifer waters. Microbial Ecology, v. 44, p. 95-106, 2002. 
BALDI, P. HATFIELD, G. W. DNA microarrays and gene expression: from experiments to data analysis and modeling: Secondary DNA microarrays and gene expression: from experiments to data analysis and modeling. New York: Cambridge University Press, 2002. $214 \mathrm{p}$.

BALDWIN, B. R.; NAKATSU, C. H.; NIES, L. Detection and enumeration of aromatic oxygenase genes by multiplex and real-time PCR. Applied and Environmental Microbiology, v. 69, p. 3350-3358, 2003.

BAMFORTH, S. M. SINGLETON, I. Bioremediation of polycyclic aromatic hydrocarbons: current knowledge and future directions. Journal of Chemical Technology \& Biotechnology, v. 80, p. 723-736, 2005.

BATIE, C.; BALLOU, D. P.; CORELL, C. C. Phythalate dioxygenase reductase and related flavin-iron-sulfur containing electron transferases. In: MÜLLER, F. (Ed.). Chemistry and Biochemistry of Flavoenzymes. Boca Raton: CRC Press, 1991. v. 3. p. 543-556.

BATTIN, T. J.; SLOAN, W. T.; KJELLEBERG, S.; DAIMS, H.; HEAD, I. M.; CURTIS, T. P.; EBERL, L. Microbial landscapes: new paths to biofilm research. Nature Reviews Microbiology, v. 5, p. 76-81, 2007.

BELICANTA, G. S. Diversidade de genes catabólicos em amostras de sedimentos do Sistema Estuarino de Santos e São Vicente, SP. 2004. 108 f. Tese (Doutorado em Microbiologia) - Instituto de Ciências Biomédicas, Universidade de São Paulo, São Paulo, 2004.

BELLER, H. R.; CHAIN, P. S. G.; LETAIN, T. E.; CHAKICHERLA, A.; LARIMER, F. W.; RICHARDSON, P. M.; COLEMAN, M. A.; WOOD, A. P.; KELLY, D. P. The genome sequence of the obligately chemolithoautotrophic, facultatively anaerobic bacterium Thiobacillus denitrificans. Journal of Bacteriology, v. 188, p. 1473-1488, 2006.

BELLER, H. R.; KANE, S. R.; LEGLER, T. C.; ALVAREZ, P. J. J. A real-time polymerase chain reaction method for monitoring anaerobic, hydrocarbon-degrading Bacteria based on a catabolic gene. Environmental Science \& Technology, v. 36, p. 3977-3984, 2002.

BEN HANIA, W.; FRAJ, B.; POSTEC, A.; FADHLAOUI, K.; HAMDI, M.; OLLIVIER, B.; FARDEAU, M.-L. Fusibacter tunisiensis sp. nov., isolated from an anaerobic reactor used to treat olive-mill wastewater. International Journal of Systematic and Evolutionary Microbiology, v. 62, p. 1365-1368, 2012.

BERRY, C. The bacterium, Lysinibacillus sphaericus, as an insect pathogen. Journal of Invertebrate Pathology, v. 109, p. 1-10, 2012.

BERTACINI, P. V. Biodegradação de bifenilos policlorados (PCBs) no estuário de Santos -SP. 1998. 87 f. - Instituto de Ciências Biomédicas, Universidade de São Paulo, São Paulo, 1998.

BHARALI, P.; DAS, S.; KONWAR, B. K.; THAKUR, A. J. Crude biosurfactant from thermophilic Alcaligenes faecalis: feasibility in petro-spill bioremediation. International Biodeterioration \& Biodegradation, v. 65, p. 682-690, 2011. 
BINLADEN, J.; GILBERT, M. T. P.; BOLLBACK, J. P.; PANITZ, F.; BENDIXEN, C.; NIELSEN, R.; WILLERSLEV, E. The use of coded PCR primers enables high-throughput sequencing of multiple homolog amplification products by 454 parallel sequencing. PLoS One, v. 2, p. e197, 2007.

BLASCO, F.; SAENGER, P.; JANODET, E. Mangroves as indicators of coastal change. Catena, v. 27, p. 167-178, 1996.

BLUM, P.; HUNKELER, D.; WEEDE, M.; BEYER, C.; GRATHWOHL, P.; MORASCH, B. Quantification of biodegradation for o-xylene and naphthalene using first order decay models, Michaelis-Menten kinetics and stable carbon isotopes. Journal of Contaminant Hydrology, v. 105, p. 118-130, 2009.

BOMBACH, P.; CHATZINOTAS, A.; NEU, T. R.; KÄSTNER, M.; LUEDERS, T.; VOGT, C. Enrichment and characterization of a sulfate-reducing toluene-degrading microbial consortium by combining in situ microcosms and stable isotope probing techniques. FEMS Micriobiology Ecology, 2009.

BONETTI, C. Foraminíferos como bioindicadores do gradiente de estresse ecológico em ambientes costeiros poluídos. Estudo aplicado ao Sistema estuarino de Santos-São Vicente (SP, Brasil). 2000. 229 f. Tese (Doutorado em Oceanografia Biológica) - Instituto Oceanográfico, Universidade de São Paulo, São Paulo, 2000.

BORJA, J.; TALEON, D. M.; AURESENIA, J.; GALLARDO, S. Polychlorinated biphenyls and their biodegradation. Process Biochemistry, v. 40, p. 1999-2013, 2005.

BRAAK, C. J. F. T. SMILAUER, P. CANOCO reference manual and canodraw for windows user's guide: software for canonical community ordination (version 4.5). Ithaca NY, USA. 2002

BRANDAN, E. HIRSCHBERG, C. B. Purification of rat liver N-heparan-sulfate sulfotransferase. Journal of Biological Chemistry, v. 263, p. 2417-2422, 1988.

BRANDT, C. A.; BECKER, J. M.; PORTA, A. Distribution of polycyclic aromatic hydrocarbons in soils and terrestrial biota after a spill of crude oil in Trecate, Italy. Environmental Toxicology and Chemistry, v. 21, p. 1638-1643, 2002.

BREIVIK, K.; ALCOCK, R.; LI, Y.-F.; BAILEY, R. E.; FIEDLER, H.; PACYNA, J. M. Primary sources of selected POPs: regional and global scale emission inventories. Environmental Pollution, v. 128, p. 3-16, 2004.

BREIVIK, K.; SWEETMAN, A.; PACYNA, J. M.; JONES, K. C. Towards a global historical emission inventory for selected PCB congeners-a mass balance approach: global production and consumption. Science of The Total Environment, v. 290, p. 181-98, 2002a.

BREIVIK, K.; SWEETMAN, A.; PACYNA, J. M.; JONES, K. C. Towards a global historical emission inventory for selected PCB congeners - a mass balance approach: emissions. Science of The Total Environment, v. 290, p. 199-224, 2002b. 
BREIVIK, K.; SWEETMAN, A.; PACYNA, J. M.; JONES, K. C. Towards a global historical emission inventory for selected PCB congeners - a mass balance approach: an update. Science of The Total Environment, v. 377, p. 296-307, 2007.

BRENNER, R. C.; MAGAR, V. S.; ICKES, J. A.; ABBOTT, J. E.; STOUT, S. A.; CRECELIUS, E. A.; BINGLER, L. S. Characterization and fate of PAH-contaminated sediments at the wyckoff/eagle harbor superfund site. Environmental Science \& Technology, v. 36, p. 2605-2613, 2002.

BRITO, E. M. S.; DURAN, R.; GUYONEAUD, R.; GOÑI-URRIZA, M.; GARCÍA DE OTEYZA, T.; CRAPEZ, M. A. C.; ALELUIA, I.; WASSERMAN, J. C. A. A case study of in situ oil contamination in a mangrove swamp (Rio De Janeiro, Brazil). Marine Pollution Bulletin, v. 58, p. 418-423, 2009.

BRITO, E. M. S.; GUYONEAUD, R.; GOÑI-URRIZA, M.; RANCHOU-PEYRUSE, A.; VERBAERE, A.; CRAPEZ, M. A. C.; WASSERMAN, J. C. A.; DURAN, R. Characterization of hydrocarbonoclastic bacterial communities from mangrove sediments in Guanabara Bay, Brazil. Research in Microbiology, v. 157, p. 752-62, 2006.

BROWN, P. O. BOTSTEIN, D. Exploring the new world of the genome with DNA microarrays. Nature Genetics, v. 21, p. 33-37, 1999.

BUGG, T. D. H. WINFIELD, C. J. Enzymatic cleavage of aromatic rings: mechanistic aspects of the catechol dioxygenases and later enzymes of bacterial oxidative cleavage pathways. Natural Product Reports, v. 15, p. 513-530, 1998.

BURNS, K.; GARRITY, S.; LEVINGS, S. How many years until mangrove ecosystems recover from catastrophic oil spills? Marine Pollution Bulletin, v. 26, p. 239-248, 1993.

BURR, M. D.; CLARK, S. J.; SPEAR, C. R.; CAMPER, A. K. Denaturing gradient gel electrophoresis can rapidly display the bacterial diversity contained in $16 \mathrm{~S}$ rDNA clone libraries. Microbial Ecology, v. 51, p. 479-486, 2006.

BUTLER, C. S. MASON, J. R. Structure-function analysis of the bacterial aromatic ringhydroxylating dioxygenases. In: POOLE, R. K. (Ed.). Advances in Microbial Physiology. Academic Press, 1996. v. 38. p. 47-84.

CASTINE, S. A.; BOURNE, D. G.; TROTT, L. A.; MCKINNON, D. A. Sediment microbial community analysis: establishing impacts of aquaculture on a tropical mangrove ecosystem. Aquaculture, v. 297, p. 91-98, 2009.

CÉBRON, A.; NORINI, M.-P.; BEGUIRISTAIN, T.; LEYVAL, C. Real-time PCR quantification of PAH-ring hydroxylating dioxygenase (PAH-RHD[alpha]) genes from Gram positive and Gram negative bacteria in soil and sediment samples. Journal of Microbiological Methods, v. 73, p. 148-159, 2008.

CETESB - PAULO, COMPANHIA AMBIENTAL DO ESTADO DE SÃO. Gerenciamento de riscos: vazamentos de óleo. São Paulo. Acesso em 12 de agosto de 2012. Disponível em: http://www.cetesb.sp.gov.br/userfiles/file/emergencias-quimicas/panorama-geral/25Principais-ocorrencias-quadro.pdf. 
CHADHAIN, S. M. N.; NORMAN, R. S.; PESCE, K. V.; KUKOR, J. J.; ZYLSTRA, G. J. Microbial dioxygenase gene population shifts during polycyclic aromatic hydrocarbon biodegradation. Applied and Environmental Microbiology, v. 72, p. 4078-4087, 2006.

CHAIN, P. S.; DENEF, V. J.; KONSTANTINIDIS, K. T.; VERGEZ, L. M.; AGULLO, L.; REYES, V. L.; HAUSER, L.; CORDOVA, M.; GOMEZ, L.; GONZALEZ, M.; LAND, M.; LAO, V.; LARIMER, F.; LIPUMA, J. J.; MAHENTHIRALINGAM, E.; MALFATTI, S. A.; MARX, C. J.; PARNELL, J. J.; RAMETTE, A.; RICHARDSON, P.; SEEGER, M.; SMITH, D.; SPILKER, T.; SUL, W. J.; TSOI, T. V.; ULRICH, L. E.; ZHULIN, I. B.; TIEDJE, J. M. Burkholderia xenovorans LB400 harbors a multi-replicon, 9.73-Mbp genome shaped for versatility. Proceedings of the National Academy of Sciences of the United States of America, v. 103, p. 15280-15287, 2006.

CHAKRABORTY, R. COATES, J. D. Anaerobic degradation of monoaromatic hydrocarbons. Applied Microbiology and Biotechnology, v. 64, p. 437-446, 2004.

CHANG, B. V.; CHANG, I. T.; YUAN, S. Y. Biodegradation of phenanthrene and pyrene from mangrove sediment in subtropical Taiwan. Journal of Environmental Science and Health, v. 43, p. 233-238, 2008.

CHENG, H. HU, Y. Curbing dioxin emissions from municipal solid waste incineration in China: Re-thinking about management policies and practices. Environmental Pollution, v. 158, p. 2809-2814, 2010.

CHEUNG, V. G.; MORLEY, M.; AGUILAR, F.; MASSIMI, A.; KUCHERLAPATI, R.; CHILDS, G. Making and reading microarrays. Nature Genetics, v. 21, p. 15-19, 1999.

CHO, J.-C. TIEDJE, J. M. Bacterial species determination from DNA-DNA hybridization by using genome fragments and DNA microarrays. Applied and Environmental Microbiology, v. 67, p. 3677-3682, 2001.

CLEARY, D. F.; SMALLA, K.; MENDONCA-HAGLER, L. C.; GOMES, N. C. Assessment of variation in bacterial composition among microhabitats in a mangrove environment using DGGE fingerprints and barcoded pyrosequencing. PLoS One, v. 7, p. e29380, 2012.

COIMBRA, M. A. C. Avaliação dos resultados analíticos de hidrocarbonetos como instrumento jurídico em caso de derrames de petróleo. Estudo de caso. 2006. 108 f. Dissertação (Mestrado em Oceanografia Química e Geológica) - Instituto Oceanográfico, Universidade de São Paulo, São Paulo, 2006.

CUNHA-LIGNON, M. Dinâmica do manguezal do sistema Cananéia-Iguape, estado de São Paulo-Brasil. 2001. Dissertação (Mestrado em Oceanografia Biológica) - Instituto Oceanográfico, Universidade de São Paulo, São Paulo, 2001.

CUNHA-LIGNON, M.; COELHO-JR, C.; ALMEIDA, R.; MENGHINI, R. P.; SCHAEFFER-NOVELLI, Y.; CINTRÓN-MOLERO, G.; DAHDOUH-GUEBAS, F. Characterisation of mangrove forest types in view of conservation and management: a review of mangals at the Cananéia region, São Paulo State, Brazil. Journal of Coastal Research, v. S164, p. 349-353, 2011a. 
CUNHA-LIGNON, M.; KAMPEL, M.; MENGHINI, R. P.; SCHAEFFER-NOVELLI, Y.; CINTRÓN-MOLERO, G.; DAHDOUH-GUEBAS, F. Mangrove forests submitted to depositional processes and salinity variation investigated using satellite images and vegetation structure surveys. Journal of Coastal Research, v. S164, p. 344-346, 2011 b.

CUNHA-LIGNON, M.; MAHIQUES, M.; SCHAEFFER-NOVELLI, Y.; RODRIGUES, M.; KLEIN, D. A.; GOYA, S. C.; MENGHINI, R. P.; TOLENTINO, C. V.; CINTRÓNMOLERO, G.; DAHDOUH-GUEBAS, F. Analysis of mangrove forest sucession, using sediment cores: a case study in Cananéia Iguape coastal system, São Paulo - Brazil. Brazilian Journal of Oceanography, v. 57, p. 161-174, 2009a.

CUNHA-LIGNON, M.; MENGHINI, R. P.; SANTOS, L. C. M.; NIEMEYER-DINÓLA, C.; SCHAEFFER-NOVELLI, Y. Case studies in the mangrove forests of the state of São Paulo (Brazil): apllication of tools using different spatial and temporal scales. Journal of Integrated Costal Zone Management, v. 9, p. 79-91, 2009b.

CURY, J. C. Diversidade de Bacteria e Archaea em solos de mangue e marisma. 2006. 151 f. Tese (Doutorado em Microbiologia Agrícola) - Departamento de Microbiologia Agrícola, Escola Superior de Agricultura Luiz de Queiroz - ESALQ/USP, Piracicaba, 2006.

DA SILVA, M. L. B. ALVAREZ, P. J. J. Assessment of anaerobic benzene degradation potential using 16S rRNA gene-targeted real-time PCR. Environmental Microbiology, v. 9, p. 72-80, 2007.

DAANE, L. L.; HARJONO, I.; ZYLSTRA, G. J.; HAGGBLOM, M. M. Isolation and characterization of polycyclic aromatic hydrocarbon-degrading Bacteria associated with the rhizosphere of salt marsh plants. Applied and Environmental Microbiology, v. 67, p. 26832691, 2001.

DAS, N. CHANDRAN, P. Microbial degradation of petroleum hydrocarbon contaminants: an overview. Biotechnology REsearch International, v. 2011, p. 1-13, 2011.

DAS, S. VINCENT, J. R. Mangroves protected villages and reduced death toll during Indian super cyclone. Proceedings of the National Academy of Sciences of the United States of America, v. 106, p. 7357-60, 2009.

DAVID, C. J. Contribuição para o estudo da distribuição do microfitobentos da região entremarés de praias da Baixada Santista, Estado de São Paulo. 1997. 88 f. Dissertação (Mestrado em Oceanografia Biológica) - Instituto Oceanográfico, Universidade de São Paulo, São Paulo, 1997.

DAVIS, S. E.; CORRONADO-MOLINA, C.; CHILDERS, D. L.; DAY JR, J. W. Temporally dependent $\mathrm{C}, \mathrm{N}$, and $\mathrm{P}$ dynamics associated with the decay of Rhizophora mangle L. leaf litter in oligotrophic mangrove wetlands of the Southern Everglades. Aquatic Botany, v. 75, p. 199-215, 2003.

DE SOUZA, A. S.; TORRES, J. P. M.; MEIRE, R. O.; NEVES, R. C.; COURI, M. S.; SEREJO, C. S. Organochlorine pesticides (OCs) and polychlorinated biphenyls (PCBs) in sediments and crabs (Chasmagnathus granulata, Dana, 1851) from mangroves of Guanabara Bay, Rio de Janeiro State, Brazil. Chemosphere, v. 73, p. S186-S192, 2008. 
DEAN-ROSS, D.; MOODY, J.; CERNIGLIA, C. E. Utilization of mixtures of polycyclic aromatic hydrocarbons by bacteria isolated from contaminated sediment. FEMS Microbiology Ecology, v. 41, p. 1-7, 2002.

DIAS, A. C. F. Diversidade de arquéias e bactérias envolvidas na ciclagem do nitrogênio em sedimentos de manguezais. 2012. 94 f. Tese (Doutorado em Biologia na Agricultura e no Ambiente) - Centro de Energia Nuclear na Agricultura, Universidade de São Paulo, Piracicaba, 2012.

DIAS, A. C. F.; ANDREOTE, F. D.; RIGONATO, J.; FIORE, M. F.; MELO, I. S.; ARAÚJO, W. L. The bacterial diversity in a Brazilian non-disturbed mangrove sediment. Antonie van Leeuwenhoek, v. 98, p. 541-551, 2010.

DIAS, A. C. F.; DINI-ANDREOTE, F.; TAKETANI, R.; TSAI, S.; AZEVEDO, J.; DE MELO, I.; ANDREOTE, F. Archaeal communities in the sediments of three contrasting mangroves. Journal of Soils and Sediments, v. 11, p. 1466-1476, 2011.

DÍAZ, E. Bacterial degradation of aromatic pollutants: a paradigm of metabolic versatility. International Microbiology, v. 7, p. 173-180, 2004.

DIONISI, H. M.; CHEWNING, C. S.; MORGAN, K. H.; MENN, F.-M.; EASTER, J. P.; SAYLER, G. S. Abundance of dioxygenase genes similar to Ralstonia sp. strain U2 nagAc Is correlated with naphthalene concentrations in coal tar-contaminated freshwater sediments. Applied and Environmental Microbiology, v. 70, p. 3988-3995, 2004.

DIONISI, H. M.; HARMS, G.; LAYTON, A. C.; GREGORY, I. R.; PARKER, J.; HAWKINS, S. A.; ROBINSON, K. G.; SAYLER, G. S. Power analysis for real-time PCR quantification of genes in activated sludge and analysis of the variability introduced by DNA extration. Applied and Environmental Microbiology, v. 69, p. 6597-6604, 2003.

DRAMANAC, R.; LABAT, I.; BRUKNER, I.; CRKVENJAKOV, R. Sequencing of megabase plus DNA by hybridization: theory of the method. Genomics, v. 4, p. 114-128, 1989.

DUBEY, S. K.; TRIPATHI, A. K.; UPADHYAY, S. N. Exploration of soil bacterial communities for their potential as bioresource. Bioresource Technology, v. 97, p. 2217-2224, 2006.

DUKE, N.; MEYNECKE, J.-O.; DITTMANN, S.; ELLISON, A.; ANGER, K.; BERGER, U.; CANNICCI, S.; DIELE, K.; EWEL, K.; FIELD, C.; KOEDAM, N.; LEE, S.; MARCHAND, C.; NORDHAUS, I.; DAHDOUH-GUEBAS, F. A world without mangroves ? Science, v. 317, p. 41-43, 2007.

DYKE, P.; COLEMAN, P.; JAMES, R. Dioxins in ambient air, bonfire night 1994. Chemosphere, v. 34, p. 1191-1201, 1997.

DYKE, P. H.; FOAN, C.; FIEDLER, H. PCB and PAH releases from power stations and waste incineration processes in the UK. Chemosphere, v. 50, p. 469-480, 2003. 
EDWARDS, J. R.; KIM, D. H.; JU, J. An integrated system for DNA sequencing by synthesis. In: KEITH, R. MITCHELSON (Ed.). Perspectives in Bioanalysis. Elsevier, 2007. v. 2. p. $187-205$.

EHRENREICH, A. DNA microarray technology for the microbiologist: an overview. Applied Microbiology and Biotechnology, v. 73, p. 255-273, 2006.

EL-TARABILY, K. A. Total microbial activity and microbial composition of a mangrove sediment are reduced by oil pollution at a site in the Arabian Gulf. Canadian Journal of Microbiology, v. 48, p. 176-182, 2002.

ELAHI, E. RONAGHI, M. Determination of nucleic acid sequences by pyrosequencing. In: RALPH, R.; STUART, R. (Ed.). Molecular Analysis and Genome Discovery. West Sussex: John Wiley \& Sons, Ltd., 2004. p. 101-111.

ENTCHEVA, P.; LIEBL, W.; JOHANN, A.; HARTSCH, T.; STREIT, W. R. Direct cloning from enrichment cultures, a reliable strategy for isolation of complete operons and genes from microbial consortia. Applied and Environmental Microbiology, v. 67, p. 89-99, 2001.

ENVIRONMENTAL PROTECTION AGENCY - US EPA. Code of federal regulations: title 40 protection of environment - toxic pollutants: Secondary Code of federal regulations: title 40 protection of environment - toxic pollutants. Washington: United States Environmental Protection Agency - US EPA, 2009. 708 p.

ETTEMA, T. J. ANDERSSON, S. G. The alpha-proteobacteria: the Darwin finches of the bacterial world. Biology letters, v. 5, p. 429-432, 2009.

FAHY, A.; LETHBRIDGE, G.; EARLE, R.; BALL, A. S.; TIMMIS, K. N.; MCGENITY, T. J. Effects of long-term benzene pollution on bacterial diversity and community structure in groundwater. Environmental Microbiology, v. 7, p. 1192-9, 2005.

FAROON, O.; JONES, D.; DE ROSA, C. Effects of polychlorinated biphenyls on the nervous system. Toxicology and Industrial Health, v. 16, p. 307-333, 2000.

FAUTH, J. E.; BERNARDO, J.; CAMARA, M.; RESETARITS, W. J.; BUSKIRK, V.; A., S. Simplifying the jargon of community ecology: a conceptual approach. The American Naturalist, v. 147, p. 282-286, 1996.

FEIN, G. G.; JACOBSON, J. L.; JACOBSON, S. W.; SCHWARTZ, P. M.; DOWLER, J. K. Prenatal exposure to polychlorinated biphenyls: effects on birth size and gestational age. The Journal of Pediatrics, v. 105, p. 315-320, 1984.

FERHAT, S.; MNIF, S.; BADIS, A.; EDDOUAOUDA, K.; ALOUAOUI, R.; BOUCHERIT, A.; MHIRI, N.; MOULAI-MOSTEFA, N.; SAYADI, S. Screening and preliminary characterization of biosurfactants produced by Ochrobactrum sp. 1C and Brevibacterium sp. 7G isolated from hydrocarbon-contaminated soils. International Biodeterioration \& Biodegradation, v. 65, p. 1182-1188, 2011. 
FERNANDES, M. B.; BRICKUS, L. S. R.; MOREIRA, J. C.; CARDOSO, J. N. Atmospheric BTX and polyaromatic hydrocarbons in Rio de Janeiro, Brazil. Chemosphere, v. 47, p. 417425, 2002.

FERRARO, D. J.; GAKHAR, L.; RAMASWAMY, S. Rieske business: structure-function of rieske non-heme oxygenases. Biochemical and Biophysical Research Communications, v. 338, p. 175-190, 2005.

FERRE, F. Quantitative or semi-quantitative PCR: reality versus myth. PCR Methods and Applications, v. 2, p. 1-9, 1992.

FERREIRA, T.; OTERO, X.; DE SOUZA JUNIOR, V.; VIDAL-TORRADO, P.; MACÍAS, F.; FIRME, L. Spatial patterns of soil attributes and components in a mangrove system in Southeast Brazil (São Paulo). Journal of Soils and Sediments, v. 10, p. 995-1006, 2010.

FILONOV, A.; AKHMETOV, L.; PUNTUS, I.; ESIKOVA, T.; GAFAROV, A.; KOSHELEVA, I.; BORONIN, A. Horizontal transfer of catabolic plasmids and naphthalene biodegradation in open soil. Microbiology, v. 79, p. 184-190, 2010.

FISHER, K. PHILLIPS, C. The ecology, epidemiology and virulence of Enterococcus. Microbiology, v. 155, p. 1749-1757, 2009.

FLOCCO, C. G.; GOMES, N. C. M.; MAC CORMACK, W.; SMALLA, K. Occurrence and diversity of naphthalene dioxygenase genes in soil microbial communities from the Maritime Antarctic. Environmental Microbiology, v. 11, p. 700-714, 2009.

FOGHT, J. Anaerobic biodegradation of aromatic hydrocarbons: pathways and prospects. Journal of Molecular Microbiology and Biotechnology, v. 15, p. 93-120, 2008.

FRAZÃO, L. R. Eutrofização por esgotos domésticos e sua relação com a fisiologia e ecologia do fitoplâncton no litoral do Estado de São Pauo (Ubatuba, Praia Grande e Santos). 2001. 180 f. Dissertação (Mestrado em Oceanografia Biológica) - Instituto Oceanográfico, Universidade de São Paulo, São Paulo, 2001.

FRENCH, C. E.; NICKLIN, S.; BRUCE, N. C. Aerobic degradation of 2,4,6-trinitrotoluene by Enterobacter cloacae PB2 and by pentaerythritol tetranitrate reductase. Applied and Environmental Microbiology, v. 64, p. 2864-2868, 1998.

FROELICH, P. N.; KLINKHAMMER, G. P.; BENDER, M. L.; LUEDTKE, N. A.; HEATH, G. R.; CULLEN, D.; DAUPHIN, P.; HAMMOND, D.; HARTMAN, B.; MAYNARD, V. Early oxidation of organic matter in pelagic sediments of the eastern equatorial Atlantic: suboxic diagenesis. Geochimica et Cosmochimica Acta, v. 43, p. 1075-1090, 1979.

FURUKAWA, K. FUJIHARA, H. Microbial degradation of polychlorinated biphenyls: Biochemical and molecular features. Journal of Bioscience and Bioengineering, v. 105, p. 433-449, 2008.

FURUKAWA, K. MIYAZAKI, T. Cloning of a gene cluster encoding biphenyl and chlorobiphenyl degradation in Pseudomonas pseudoalcaligenes. Journal of Bacteriology, v. 166, p. 392-398, 1986. 
GENTRY, T.; WICKHAM, G.; SCHADT, C.; HE, Z.; ZHOU, J. Microarray applications in microbial ecology research. Microbial Ecology, v. 52, p. 159-175, 2006.

GIBSON, D. T. PERALES, R. E. Aromatic hydrocarbon dioxygenases in environmental biotechnology. Current Opinion in Biotechnology, v. 11, p. 481-492, 2000.

GIRI, C. MUHLHAUSEN, J. Mangrove forest distributions and dynamics in Madagascar (1975-2005). Sensors, v. 8, p. 2104-2117, 2008.

GIRI, C.; OCHIENG, E.; TIESZEN, L. L.; ZHU, Z.; SINGH, A.; LOVELAND, T.; MASEK, J.; DUKE, N. Status and distribution of mangrove forests of the world using earth observation satellite data. Global Ecology and Biogeography, v. 20, p. 154-159, 2011.

GOMES, N. C. M.; BORGES, L. R.; PARANHOS, R.; PINTO, F. N.; KRÖGERRECKLENFORT, E.; MENDONÇA-HAGLER, L. C. S.; SMALLA, K. Diversity of ndo genes in mangrove sediments exposed to different sources of polycyclic aromatic hydrocarbon pollution. Applied and Environmental Microbiology, v. 73, p. 7392-7399, 2007.

GOMES, N. C. M.; BORGES, L. R.; PARANHOS, R.; PINTO, F. N.; MENDONCAHAGLER, L. C. S.; SMALLA, K. Exploring the diversity of bacterial communities in sediments of urban mangrove forests. FEMS Microbiology Ecology, v. 66, p. 96-109, 2008.

GOUD, R. K.; RAGHAVULU, S. V.; MOHANAKRISHNA, G.; NARESH, K.; MOHAN, S. V. Predominance of Bacilli and Clostridia in microbial community of biohydrogen producing biofilm sustained under diverse acidogenic operating conditions. International Journal of Hydrogen Energy, v. 37, p. 4068-4076, 2012.

GRIMM, A. HARWOOD, C. Chemotaxis of Pseudomonas spp. to the polyaromatic hydrocarbon naphthalene. Applied and Environmental Microbiology, v. 63, p. 4111-4115, 1997.

GRUNTZIG, V.; NOLD, S. C.; ZHOU, J.; TIEDJE, J. M. Pseudomonas stutzeri nitrite reductase dene abundance in environmental samples measured by real-time PCR. Applied and Environmental Microbiology, v. 67, p. 760-768, 2001.

GUO, C. L.; ZHOU, H. W.; WONG, Y. S.; TAM, N. F. Y. Isolation of PAH-degrading bacteria from mangrove sediments and their biodegradation potential. Marine Pollution Bulletin, v. 51, p. 1054-61, 2005.

GUO, Y. L.; HSU, P.-C.; HSU, C.-C.; LAMBERT, G. H. Semen quality after prenatal exposure to polychlorinated biphenyls and dibenzofurans. The Lancet, v. 356, p. 1240-1241, 2000.

GUO, Y. L. L.; LAMBERT, G. H.; HSU, C. C. Growth abnormalities in the population exposed in-utero and early postnatally to polychlorinated-biphenyls and dibenzofurans. Environmental Health Perspectives, v. 103, p. 117-122, 1995. 
GUSCHIN, D. Y.; MOBARRY, B. K.; PROUDNIKOV, D.; STAHL, D. A.; RITTMANN, B. E.; MIRZABEKOV, A. D. Oligonucleotide microchips as genosensors for determinative and environmental studies in microbiology. Applied and Environmental Microbiology, v. 63, p. 2397-402, 1997.

HABE, H. OMORI, T. Genetics of polycyclic aromatic hydrocarbon metabolism in diverse aerobic bacteria. Bioscience Biotechnology and Biochemistry, v. 67, p. 225-243, 2003.

HALL, N. Advanced sequencing technologies and their wider impact in microbiology. Journal of Experimental Biology, v. 209, p. 1518-1525, 2007.

HALL, T. A. BioEdit: a user-friendly biological sequence alignment editor and analysis program for windows 95/98/NT. Nucleic Acids Symposium Series, v. 41, p. 95-98, 1999.

HANDELSMAN, J. Metagenomics: application of genomics to uncultured microorganisms. Microbiology and Molecular Biology Reviews, v. 68, p. 669-685, 2004.

HATTA, T.; MUKERJEE-DHAR, G.; DAMBORSKY, J.; KIYOHARA, H.; KIMBARA, K. Characterization of a novel thermostable Mn(II)-dependent 2,3-dihydroxybiphenyl 1,2dioxygenase from a polychlorinated biphenyl and naphthalene-degrading Bacillus sp. JF8. Journal of Biological Chemistry, v. 278, p. 21483-21492, 2003.

HAUSDORF, B. Progress toward a general species concept. Evolution, v. 65, p. 923-931, 2011.

HAZEN, T. C.; DUBINSKY, E. A.; DESANTIS, T. Z.; ANDERSEN, G. L.; PICENO, Y. M.; SINGH, N.; JANSSON, J. K.; PROBST, A.; BORGLIN, S. E.; FORTNEY, J. L.; STRINGFELLOW, W. T.; BILL, M.; CONRAD, M. E.; TOM, L. M.; CHAVARRIA, K. L.; ALUSI, T. R.; LAMENDELLA, R.; JOYNER, D. C.; SPIER, C.; BAELUM, J.; AUER, M.; ZEMLA, M. L.; CHAKRABORTY, R.; SONNENTHAL, E. L.; D'HAESELEER, P.; HOLMAN, H.-Y. N.; OSMAN, S.; LU, Z.; VAN NOSTRAND, J. D.; DENG, Y.; ZHOU, J.; MASON, O. U. Deep-Sea oil plume enriches indigenous oil-degrading bacteria. Science, v. 330, p. 204-208, 2010.

HE, Z.; DENG, Y.; VAN NOSTRAND, J. D.; TU, Q.; XU, M.; HEMME, C. L.; LI, X.; WU, L.; GENTRY, T. J.; YIN, Y.; LIEBICH, J.; HAZEN, T. C.; ZHOU, J. GeoChip 3.0 as a highthroughput tool for analyzing microbial community composition, structure and functional activity. ISME Journal, v. 4, p. 1167-1179, 2010.

HE, Z.; DENG, Y.; ZHOU, J. Development of functional gene microarrays for microbial community analysis. Current Opinion in Biotechnology, v. 23, p. 49-55, 2012a.

HE, Z.; GENTRY, T. J.; SCHADT, C. W.; WU, L.; LIEBICH, J.; CHONG, S. C.; HUANG, Z.; WU, W.; GU, B.; JARDINE, P.; CRIDDLE, C.; ZHOU, J. GeoChip: a comprehensive microarray for investigating biogeochemical, ecological and environmental processes. ISME J, v. 1, p. 67-77, 2007.

HE, Z.; VAN NOSTRAND, J.; DENG, Y.; ZHOU, J. Development and applications of functional gene microarrays in the analysis of the functional diversity, composition, and 
structure of microbial communities. Frontiers of Environmental Science \& Engineering in China, v. 5, p. 1-20, 2011.

HE, Z.; VAN NOSTRAND, J. D.; ZHOU, J. Applications of functional gene microarrays for profiling microbial communities. Current Opinion in Biotechnology, v. 23, p. 460-466, 2012b.

HE, Z. L.; VAN NOSTRAND, J. D.; WU, L. Y.; ZHOU, J. Z. Development and application of functional gene arrays for microbial community analysis. Transactions of Nonferrous Metals Society of China, v. 18, p. 1319-1327, 2008.

HEAD, I. M.; JONES, D. M.; ROLING, W. F. M. Marine microorganisms make a meal of oil. Nature Review Microbiology, v. 4, p. 173-182, 2006.

HEIDER, J. FUCHS, G. Anaerobic metabolism of aromatic compounds. European Journal of Biochemistry, v. 243, p. 577-596, 1997.

HEISS-BLANQUET, S.; BENOIT, Y.; MARÉCHAUX, C.; MONOT, F. Assessing the role of alkane hydroxylase genotypes in environmental samples by competitive PCR. Journal of Applied Microbiology, v. 99, p. 1392-1403, 2005.

HERRMANN, S.; KLEINSTEUBER, S.; CHATZINOTAS, A.; KUPPARDT, S.; LUEDERS, T.; RICHNOW, H.-H.; VOGT, C. Functional characterization of an anaerobic benzenedegrading enrichment culture by DNA stable isotope probing. Environmental Microbiology, v. 12, p. 401-411, 2010.

HILL, D. E. Soils in tidal marshes of the northeast. Soil Science, v. 133, p. 298-304, 1982.

HOLGUIN, G.; VAZQUEZ, P.; BASHAN, Y. The role of sediment microorganisms in the productivity, conservation, and rehabilitation of mangrove ecosystems: an overview. Biology and Fertility of Soils, v. 33, p. 265-278, 2001.

HONG, K.; GAO, A.-H.; XIE, Q.-Y.; GAO, H.; ZHUANG, L.; LIN, H.-P.; YU, H.-P.; LI, J.; YAO, X.-S.; GOODFELLOW, M.; RUAN, J.-S. Actinomycetes for marine drug discovery isolated from mangrove soils and plants in China. Marine Drugs, v. 7, p. 24-44, 2009.

HOSODA, A.; KASAI, Y.; HAMAMURA, N.; TAKAHATA, Y.; WATANABE, K. Development of a PCR method for the detection and quantification of benzoyl-CoA reductase genes and its application to monitored natural attenuation. Biodegradation, v. 16, p. 591-601, 2005.

HOSSEINKHANI, S. Molecular enigma of multicolor bioluminescence of firefly luciferase. Cellular and Molecular Life Sciences, v. 68, p. 1167-1182, 2011.

HRISTOVA, K. R. LUTENEGGER, C. M. Detection and quantification of methyl tert-butyl ether-degrading strain PM1 by real-time TaqMan PCR. Applied and Environmental Microbiology, v. 67, p. 5154-5160, 2001. 
HSU, P.-C.; HUANG, W.; YAO, W.-J.; WU, M.-H.; GUO, Y. L.; LAMBERT, G. H. Sperm changes in men exposed to polychlorinated biphenyls and dibenzofurans. JAMA: The Journal of the American Medical Association, v. 289, p. 2943-2944, 2003.

HUSE, S. M.; HUBER, J. A.; MORRISON, H. G.; SOGIN, M. L.; WELCH, D. M. Accuracy and quality of massively parallel DNA pyrosequencing. Genome Biology, v. 8, p. R143, 2007.

INTERNATIONAL AGENCY FOR RESEARCH ON CANCER - IARC. Some nonheterocyclic polycyclic aromatic hydrocarbons and some related exposures: Secondary Some non-heterocyclic polycyclic aromatic hydrocarbons and some related exposures. Lyon, France, 2010. 868 p.

IWAI, S.; CHAI, B.; SUL, W. J.; COLE, J. R.; HASHSHAM, S. A.; TIEDJE, J. M. Genetargeted-metagenomics reveals extensive diversity of aromatic dioxygenase genes in the environment. The ISME Journal, v. 4, p. 279-285, 2010.

JACOBI, C. SCHAEFFERNOVELLI, Y. Oil spills in mangroves: a conceptual model based on long-term field observations. Ecological Modelling, v. 52, p. 53-59, 1990.

JACQUES, R. J. S.; SANTOS, E. C.; BENTO, F. M.; PERALBA, M. C. R.; SELBACH, P. A.; SÁ, E. L. S.; CAMARGO, F. A. O. Anthracene biodegradation by Pseudomonas sp. isolated from a petrochemical sludge landfarming site. International Biodeterioration \& Biodegradation, v. 56, p. 143-150, 2005.

JANSSEN, P. H. Identifying the dominant soil bacterial taxa in libraries of 16S rRNA and 16S rRNA genes. Applied and Environmental Microbiology, v. 72, p. 1719-1728, 2006.

JENNERJAHN, T. C. ITTEKKOT, V. Relevance of mangroves for the production and deposition of organic matter along tropical continental margins. Naturwissenschaften, v. 89, p. 23-30, 2002.

JIMÉNEZ, J. L.; MIÑAMBRES, B.; GARCÍA, J. L.; DÍAZ, E. Genomic Insights in the metabolism of aromatic compounds in Pseudomonas. In: RAMOS, J. L. (Ed.). Pseudomonas: biosynthesis of macromolecules and molecular metabolism. New York: Plenun Publishers, 2004. v. 3. p. 425-462.

JOHN, P. WHATLEY, F. R. Paracoccus denitrificans and the evolutionary origin of the mitochondrion. Nature, v. 254, p. 495-498, 1975.

JOLY, P.; FALCONNET, P.-A.; ANDRE, J.; WEILL, N.; REYROLLE, M.; MAURIN, M.; ETIENNE, J.; JARRAUD, S.; AL, J. E. T. Quantitative real-time Legionella PCR for environmental water samples: sata interpretation. Applied and Environmental Microbiology, v. 72, p. 2801-2808, 2006.

JUCK, D.; CHARLES, T.; WHYTE, L. G.; GREER, C. W. Polyphasic microbial community analysis of petroleum hydrocarbon-contaminated soils from two northern Canadian communities. FEMS Microbiology Ecology, v. 33, p. 241-249, 2000. 
JURELEVICIUS, D.; ALVAREZ, V. M.; PEIXOTO, R.; ROSADO, A. S.; SELDIN, L. Bacterial polycyclic aromatic hydrocarbon ring-hydroxylating dioxygenases (PAH-RHD) encoding genes in different soils from King George Bay, Antarctic Peninsula. Applied Soil Ecology, v. 55, p. 1-9, 2012.

KÄMPFER, P. GLAESER, S. P. Prokaryotic taxonomy in the sequencing era - the polyphasic approach revisited. Environmental Microbiology, v. 14, p. 291-317, 2012.

KANALY, R. A.; BARTHA, R.; WATANABE, K.; HARAYAMA, S. Rapid mineralization of benzo[a]pyrene by a microbial consortium growing on diesel fuel. Applied and Environmental Microbiology, v. 66, p. 4205-11, 2000a.

KANALY, R. A. HARAYAMA, S. Biodegradation of high-molecular-weight polycyclic aromatic hydrocarbons by Bacteria. Journal of Bacteriology, v. 182, p. 2059-2067, 2000b.

KASAI, Y.; KISHIRA, K.; SYUTSUBO, K.; HARAYMA, S. Molecular detection of marine bacterial population on beaches contaminated by the Nakhodka tanker oil-spill accident. Environmental Microbiology, v. 3, p. 246-255, 2001.

KATHIRESAN, K. BINGHAM, B. L. Biology of mangroves and mangrove ecosystems. Advances in Marine Biology, v. 40, p. 1-145, 2001.

KATSIVELA, E.; MOORE, E. R. B.; KALOGERAKIS, N. Monitoring of the microbial activities and the diversity of the microbial community degrading refinery waste sludge. Water Air Soil Pollut Focus, v. 4, p. 75-85, 2004.

KAZAKOV, A. E.; RODIONOV, D. A.; ALM, E.; ARKIN, A. P.; DUBCHAK, I.; GELFAND, M. S. Comparative genomics of regulation of fatty acid and branched-chain amino acid utilization in Proteobacteria. Journal of Bacteriology, v. 191, p. 52-64, 2009.

KE, L.; WONG, T. W. Y.; WONG, Y. S.; TAM, N. F. Y. Fate of polycyclic aromatic hydrocarbon (PAH) contamination in a mangrove swamp in Hong Kong following an oil spill. Marine Pollution Bulletin, v. 45, p. 339-47, 2002.

KELLY, B. T.; BARET, J.-C.; TALY, V.; GRIFFITHS, A. D. Miniaturizing chemistry and biology in microdroplets. Chemical Communications, p. 1773-1788, 2007.

KIM, M. K.; SRINIVASAN, S.; KIM, Y.-J.; YANG, D.-C. Castellaniella ginsengisoli sp. nov., a $\beta$-glucosidase-producing bacterium. International Journal of Systematic and Evolutionary Microbiology, v. 59, p. 2191-2194, 2009.

KIMBARA, K. Recent developments in the study of microbial aerobic degradation of polychlorinated biphenyls. Microbes and Environments, v. 20, p. 127-134, 2005.

KIMBARA, K.; HASHIMOTO, F.; FUKUDA, M.; KOANA, T.; TAKAGI, M.; OISHI, M.; YANO, K. Cloning and sequencing of two tandem genes involved in degradation of 2,3dihydroxybiphenyl to benzoic acid in the polychlorinated biphenyl-degrading soil bacterium Pseudomonas sp. strain KKS102. Journal of Bacteriology, v. 171, p. 2740-2747, 1989. 
KIMBROUGH, R. D.; DOEMLAND, M. L.; KROUSKAS, C. A. Analysis of research studying the effects of polychlorinated biphenyls and related chemicals on neurobehavioral development in children. Veterinary and Human Toxicology, v. 43, p. 220-228, 2001.

KIMBROUGH, R. D.; DOEMLAND, M. L.; MANDEL, J. S. A mortality update of male and female capacitor workers exposed to polychlorinated biphenyls. Journal of Occupational and Environmental Medicine, v. 45, p. 271-282, 2003.

KIMIRAN-ERDEM, A.; ARSLAN, E.; SANLI YURUDU, N.; ZEYBEK, Z.; DOGRUOZ, N.; COTUK, A. Isolation and identification of Enterococci from seawater samples: assessment of their resistance to antibiotics and heavy metals. Environmental Monitoring and Assessment, v. 125, p. 219-228, 2007.

KITAGAWA, W.; SUZUKI, A.; HOAKI, T.; MASAI, E.; FUKUDA, M. Multiplicity of aromatic ring hydroxylation dioxygenase genes in a strong PCB degrader, Rhodococcus sp. strain RHA1 demonstrated by denaturing gradient gel electrophoresis. Bioscience, Biotechnology, and Biochemistry, v. 65, p. 1907-1911, 2001.

KLEIN, D. Quantification using real-time PCR technology: applications and limitations. Trends in Molecular Medicine, v. 8, p. 257-260, 2002.

KOLD, S.; KNIEF, C.; STUBNER, S.; CONRAD, R. Quantitative detection of methanotrophs in soil by novel pmoA-target real-time PCR assay. Applied and Environmental Microbiology, v. 69, p. 2423-2429, 2003.

KONSTANTINIDIS, K. T.; RAMETTE, A.; TIEDJE, J. M. The bacterial species definition in the genomic era. Philosophical Transactions of the Royal Society B: Biological Sciences, v. 361, p. 1929-1940, 2006.

KORNBERG, R. D. LORCH, Y. Chromatin structure and transcription. Annual Review of Cell Biology, v. 8, p. 563-587, 1992.

KUHN, E. Diversidade dos genes funcionais alcano monoxigenases e dioxigenases que hidroxilam anéis aromáticos (ARHDs) em comunidades microbianas de sedimentos marinhos Antárticos. 2007. 161 f. Dissertação (Mestrado em Biotecnologia) - Programa de Pós-graduação Interunidades em Biotecnologia, Universidade de São Paulo, São Paulo, 2007.

KUHN, E.; BELLICANTA, G. S.; PELLIZARI, V. H. New alk genes detected in Antarctic marine sediments. Environmental Microbiology, v. 11, p. 669-673, 2009.

KULKARNI, P. S.; CRESPO, J. G.; AFONSO, C. A. M. Dioxins sources and current remediation technologies: a review. Environment International, v. 34, p. 139-153, 2008.

KUMAR, S. FULLER, C. W. Advances in dye-nucleotide conjugate chemistry for DNA sequencing. In: KEITH, R. MITCHELSON (Ed.). Perspectives in Bioanalysis. New York: Elsevier, 2007. v. 2. p. 119-149.

KURATSUNE, M. Epidemiologic study on Yusho, a poisoning caused by ingestion of rice iil contaminated with a commercial brand of Polychlorinated-Biphenyls. Current Contents/Clinical Practice, p. 22-22, 1982. 
KWEON, O.; KIM, S.-J.; BAEK, S.; CHAE, J.-C.; ADJEI, M.; BAEK, D.-H.; KIM, Y.-C.; CERNIGLIA, C. A new classification system for bacterial rieske non-heme iron aromatic ring-hydroxylating oxygenases. BMC Biochemistry, v. 9, p. 11, 2008.

LADEN, F.; COLLMAN, G.; IWAMOTO, K.; ALBERG, A. J.; BERKOWITZ, G. S.; FREUDENHEIM, J. L.; HANKINSON, S. E.; HELZLSOUER, K. J.; HOLFORD, T. R.; HUANG, H.-Y.; MOYSICH, K. B.; TESSARI, J. D.; WOLFF, M. S.; ZHENG, T.; HUNTER, D. J. 1,1-Dichloro-2,2-bis(p-chlorophenyl)ethylene and Polychlorinated Biphenyls and Breast Cancer: Combined Analysis of Five U.S. Studies. Journal of the National Cancer Institute, v. 93, p. 768-775, 2001.

LAMPARELLI, C. C. MOURA, D. O. Mapeamento dos ecossistemas costeiros do estado de São Paulo. Secretaria do Meio Ambiente do Estado de São Paulo - CETESB. São Paulo, p.108. 1999

LARKIN, M. A.; BLACKSHIELDS, G.; BROWN, N. P.; CHENNA, R.; MCGETTIGAN, P. A.; MCWILLIAM, H.; VALENTIN, F.; WALLACE, I. M.; WILM, A.; LOPEZ, R.; THOMPSON, J. D.; GIBSON, T. J.; HIGGINS, D. G. Clustal W and Clustal X version 2.0. Bioinformatics, v. 23, p. 2947-2948, 2007.

LARKIN, M. J.; KULAKOV, L. A.; ALLEN, C. C. R. Biodegradation and Rhodococcus masters of catabolic versatility. Current Opinion in Biotechnology, v. 16, p. 282-290, 2005.

LEAHY, J. G. COLWELL, R. R. Microbial degradation of hydrocarbons in the environment. Microbiological Reviews, v. 54, p. 305-315, 1990.

LEE, M.; JUNG, H.-M.; WOO, S.-G.; YOO, S.-A.; TEN, L. N. Castellaniella daejeonensis sp. nov., isolated from soil. International Journal of Systematic and Evolutionary Microbiology, v. 60, p. 2056-2060, 2010.

LEE, S. Y.; DUNN, R. J. K.; YOUNG, R. A.; CONNOLLY, R. M.; DALE, P. E. R.; DEHAYR, R.; LEMCKERT, C. J.; MCKINNON, S.; POWELL, B.; TEASDALE, P. R.; WELSH, D. T. Impact of urbanization on coastal wetland structure and function. Austral Ecology, v. 31, p. 149-163, 2006.

LEE, T. K.; LEE, J.; SUL, W. J.; IWAI, S.; CHAI, B.; TIEDJE, J. M.; PARK, J. Novel biphenyl-oxidizing bacteria and dioxygenase genes from a korean tidal mudflat. Applied and Environmental Microbiology, v. 77, p. 3888-3891, 2011.

LEI, A.-P.; HU, Z.-L.; WONG, Y.-S.; TAM, N. F.-Y. Removal of fluoranthene and pyrene by different microalgal species. Bioresource Technology, v. 98, p. 273-280, 2007.

LEIGH, M. B.; PELLIZARI, V. H.; UHLIK, O.; SUTKA, R.; RODRIGUES, J.; OSTROM, N. E.; ZHOU, J.; TIEDJE, M. Biphenyl-utilizing bacteria and their functional genes in a pine root zone contaminated with polychlorinated biphenyls (PCBs). The ISME Journal, v. 1, p. 134-148, 2007. 
LI, K.; WANG, S.; SHI, Y.; QU, J.; ZHAI, Y.; XU, L.; XU, Y.; SONG, J.; LIU, L.; RAHMAN, M. A.; YAN, Y. Genome sequence of Paracoccus sp. strain TRP, a chlorpyrifos biodegrader. Journal of Bacteriology, v. 193, p. 1786-1787, 2011.

LI, R.; ZHENG, J.; WANG, R.; SONG, Y.; CHEN, Q.; YANG, X.; LI, S.; JIANG, J. Biochemical degradation pathway of dimethoate by Paracoccus sp. Lgjj-3 isolated from treatment wastewater. International Biodeterioration \& Biodegradation, v. 64, p. 51-57, 2010.

LIANG, B.; LU, P.; LI, H.; LI, R.; LI, S.; HUANG, X. Biodegradation of fomesafen by strain Lysinibacillus sp. ZB-1 isolated from soil. Chemosphere, v. 77, p. 1614-1619, 2009.

LIANG, J.-B.; CHEN, Y.-Q.; LAN, C.-Y.; TAM, N.; ZAN, Q.-J.; HUANG, L.-N. Recovery of novel bacterial diversity from mangrove sediment. Marine Biology, v. 150, p. 739-747, 2007.

LIANG, Y.; NOSTRAND, J. D. V.; WANG, J.; ZHANG, X.; ZHOU, J.; LI, G. Microarraybased functional gene analysis of soil microbial communities during ozonation and biodegradation of crude oil. Chemosphere, v. 75, p. 193-199, 2009.

LIN, Q.; DONGHUI, W.; JIANLONG, W. Biodegradation of pyridine by Paracoccus sp. KT5 immobilized on bamboo-based activated carbon. Bioresource Technology, v. 101, p. 52295234, 2010.

LINDSTROM, J. E.; BARRY, R. P.; BRADDOCK, J. F. Long-term effects on microbial communities after a subarctic oil spill. Soil Biology and Biochemistry, v. 31, p. 1677-1689, 1999.

LIOU, J. S.-C.; DERITO, C. M.; MADSEN, E. L. Field-based and laboratory stable isotope probing surveys of the identities of both aerobic and anaerobic benzene-metabolizing microorganisms in freshwater sediment. Environmental Microbiology, v. 10, p. 1964-1977, 2008.

LLOBET, J. M.; DOMINGO, J. L.; BOCIO, A.; CASAS, C.; TEIXIDÓ, A.; MÜLLER, L. Human exposure to dioxins through the diet in Catalonia, Spain: carcinogenic and noncarcinogenic risk. Chemosphere, v. 50, p. 1193-1200, 2003.

LOPEZ, A. C. Distribuição e biodiversidade de consórcios biodegradadores de xenobióticos na baixada santista. 2002. 86 f. Dissertação (Mestrado em Microbiologia) Instituto de Ciências Biomédicas, Universidade de São Paulo, São Paulo, 2002.

LOZADA, M.; RIVA MERCADAL, J. P.; GUERRERO, L. D.; DI MARZIO, W. D.; FERRERO, M. A.; DIONISI, H. M. Novel aromatic ring-hydroxylating dioxygenase genes from coastal marine sediments of Patagonia. BMC Microbiology, v. 8, p. 50, 2008.

LUO, C.; XIE, S.; SUN, W.; LI, X.; CUPPLES, A. M. Identification of a novel toluenedegrading bacterium from the candidate phylum TM7, as determined by DNA stable isotope probing. Applied and Environmental Microbiology, v. 75, p. 4644-4647, 2009. 
LUZ, A. P. Distribuição e biodiversidade de consórcios microbianos biodegradadores de compostos xenobióticos na Baixaa Santista. 2001. 103 f. Tese (Doutorado em Microbiologia) - Instituto de Ciências Biomédicas, Universidade de São Paulo, São Paulo, 2001.

LUZ, A. P.; CIAPINA, E. M. P.; GAMBA, R. C.; LAURETTO, M. S.; MARCELO, S.; FARIAS, E. W. C.; BÍCEGO, M. C.; TANIGUCHI, S.; MONTONE, R. C.; PELLIZARI, V. H. Potencial for bioremediation of hydrocarbon polluted soils in maritme Antactic. Antarctic Science, v. 18, p. 335-343, 2006.

LUZ, A. P.; KUHN, E.; PELLIZARI, V. H. Occurence, distribution and nature of hydrocarbons-degrading genes in microorganiss from antarctic environment. In: ATAS, ASIM K. BEJ; JACKIE AISLABIE; RONALD M. (Ed.). Polar Microbiology: the ecology, biodiversity and bioremediation potential of microorganisms in extremely cold environments. Ohio: CRC Press (Taylor and Francis), 2010. v. 1. p. 339-356.

LUZ, A. P.; PELLIZARI, V. H.; WHYTE, L. G.; GREER, C. W. A survey of indigenous microbial hydrocarbon degradation genes in soils from Antarctica and Brazil. Canadian Journal of Microbiology, v. 50, p. 323-333, 2004.

MA, Y.; WANG, L.; SHAO, Z. Pseudomonas, the dominant polycyclic aromatic hydrocarbon-degrading bacteria isolated from Antarctic soils and the role of large plasmids in horizontal gene transfer. Environmental Microbiology, v. 8, p. 455-465, 2006a.

MA, Y.; WANG, L.; SHAO, Z. Pseudomonas, the dominant polycyclic aromatic hydrocarbon-degrading bacteria isolated from Antarctic soils and the role of large plasmids in horizontal gene transfer. Environmental Microbiology, v. 8, p. 455-465, 2006b.

MAIR, B. J. SCHICKTANZ, S. T. Composition of petroleum wax. Industrial \& Engineering Chemistry, v. 28, p. 1056-1057, 1936.

MARDIS, E. R. Next-generation DNA sequencing methods. Annual review of genomics and human genetics, v. 9, p. 387-402, 2008.

MARGESIN, R.; LABBE, D.; SCHINNER, F.; GREER, C. W.; WHYTE, L. G. Characterization of hydrocarbon-degrading microbial populations in contaminated and pristine Alpine soils. Applied and Environmental Microbiology, v. 69, p. 3085-3092, 2003.

MARGULIES, M.; EGHOLM, M.; ALTMAN, W. E.; ATTIYA, S.; BADER, J. S.; BEMBEN, L. A.; BERKA, J.; BRAVERMAN, M. S.; CHEN, Y.-J.; CHEN, Z.; DEWELL, S. B.; DU, L.; FIERRO, J. M.; GOMES, X. V.; GODWIN, B. C.; HE, W.; HELGESEN, S.; HO, C. H.; IRZYK, G. P.; JANDO, S. C.; ALENQUER, M. L. I.; JARVIE, T. P.; JIRAGE, K. B.; KIM, J.-B.; KNIGHT, J. R.; LANZA, J. R.; LEAMON, J. H.; LEFKOWITZ, S. M.; LEI, M.; LI, J.; LOHMAN, K. L.; LU, H.; MAKHIJANI, V. B.; MCDADE, K. E.; MCKENNA, M. P.; MYERS, E. W.; NICKERSON, E.; NOBILE, J. R.; PLANT, R.; PUC, B. P.; RONAN, M. T.; ROTH, G. T.; SARKIS, G. J.; SIMONS, J. F.; SIMPSON, J. W.; SRINIVASAN, M.; TARTARO, K. R.; TOMASZ, A.; VOGT, K. A.; VOLKMER, G. A.; WANG, S. H.; WANG, Y.; WEINER, M. P.; YU, P.; BEGLEY, R. F.; ROTHBERG, J. M. Genome sequencing in microfabricated high-density picolitre reactors. Nature, v. 437, p. 376-380, 2005. 
MARSH, S. Pyrosequencing applications. Methods in Molecular Biology, v. 373, p. 15-24, 2007.

MARTÍNKOVÁ, L.; UHNÁKOVÁ, B.; PÁTEK, M.; NEŠVERA, J.; KŘEN, V. Biodegradation potential of the genus Rhodococcus. Environment International, v. 35, p. 162-177, 2009.

MARTINS, C. C.; BICEGO, M. C.; TANIGUCHI, S.; MONTONE, R. C. Aliphatic and polycyclic aromatic hydrocarbons in surface sediments in Admiralty Bay, King George Island, Antarctica. Antarctic Science, v. 16, p. 117-122, 2004.

MAXAM, A. M. GILBERT, W. A new method for sequencing DNA. Proceedings of the National Academy of Sciences, v. 74, p. 560-564, 1977.

MAZAHERI, N. F. R.; HEUZENROEDER, M. W.; BARTON, M. D. Antimicrobial and heavy metal resistance in commensal enterococci isolated from pigs. Veterinary Microbiology, v. 148, p. 276-282, 2011.

MCINERNEY, J. O.; COTTON, J. A.; PISANI, D. The prokaryotic tree of life: past, present... and future? Trends in Ecology \& Evolution, v. 23, p. 276-281, 2008.

MEDEIROS, P. M. Avaliação da origem de hidrocarbonetos em sedimentos marinhos de Santos e São Sebastião, utilizando-se hidrocarbonetos marcadores geoquímicos. 2000. 102 f. Dissertação (Mestrado em Oceanografia Biológica) - Instituto Oceanográfico, Universidade de São Paulo, São Paulo, 2000.

MEDEIROS, P. M. BÍCEGO, M. C. Investigation of natural and anthropogenic hydrocarbon inputs in sediments using geochemical markers. Santos, SP-Brazil. Marine Pollution Bulletin, v. 49, p. 761-769, 2004.

MENGHINI, R. P.; COELHO-JR, C.; ROVAI, A. S.; CUNHA-LIGNON, M.; SCHAEFFERNOVELLI, Y.; CINTRÓN-MOLERO, G. Massive mortality of mangrove forests in Southeast Brazil (Baixada Santista, State of São Paulo) as result of harboring activities. Journal of Coastal Research, v. S164, p. 1793-1797, 2011.

MERCER, R. G.; QUINLAN, M.; ROSE, A. R.; NOLL, S.; BEATTY, J. T.; LANG, A. S. Regulatory systems controlling motility and gene transfer agent production and release in Rhodobacter capsulatus. FEMS Microbiology Letters, v. 331, p. 53-62, 2012.

MESARCH, M. B.; NAKATSU, C. H.; NIES, L. Development of catechol 2,3-dioxigenasespecific primers for monitoring bioremediation by competitive quantitative PCR. Applied and Environmental Microbiology, v. 66, p. 678-683, 2000.

MILLE, G.; ASIA, L.; GUILIANO, M.; MALLERET, L.; DOUMENQ, P. Hydrocarbons in coastal sediments from the Mediterranean sea (Gulf of Fos area, France). Marine Pollution Bulletin, v. 54, p. 566-575, 2007.

MISHRA, V.; LAL, R.; SRINIVASAN. Enzymes and operons mediating xenobiotic degradation in Bacteria. Critical Reviews in Microbiology, v. 27, p. 133-166, 2001. 
MITCHELSON, K. R.; HAWKES, D. B.; TURAKULOV, R.; MEN, A. E. Developments in DNA sequencing. In: KEITH, R. M. (Ed.). Perspectives in Bioanalysis. Elsevier, 2007. v. 2. p. 3-44.

MOHEBALI, G.; KAYTASH, A.; ETEMADI, N. Efficient breaking of water/oil emulsions by a newly isolated de-emulsifying bacterium, Ochrobactrum anthropi strain RIPI5-1. Colloids and Surfaces B: Biointerfaces, v. 98, p. 120-128, 2012.

MUKERJEE-DHAR, G.; SHIMURA, M.; MIYAZAWA, D.; KIMBARA, K.; HATTA, T. bph genes of the thermophilic PCB degrader, Bacillus sp. JF8: characterization of the divergent ring-hydroxylating dioxygenase and hydrolase genes upstream of the Mn-dependent BphC. Microbiology, v. 151, p. 4139-4151, 2005.

MULLIS, B. The unusual origin of the polymerase chain reaction. Scientific American, v. 262, p. 56-61, 1990.

MUTNURI, S.; VASUDEVAN, N.; KAESTNER, M. Degradation of anthracene and pyrene supplied by microcrystals and non-aqueous-phase liquids. Applied Microbiology and Biotechnology, v. 67, p. 569-576, 2005.

NAKIPOGLU, Y.; GÜMÜS, D.; SERTEL, S. D.; KÜÇÜKER, M. A. In vitro susceptibility of Enterococcus strains to high level aminoglycosides and heavy metals. Mikrobiyoloji Bulteni, v. 43, p. 545-551, 2009.

NAM, J. W.; NOJIRI, H.; YOSHIDA, T.; HABE, H.; YAMAME, H.; OMOR, T. New classification system for oxygenase components involved in ring-hydroxylating oxygenations. Bioscience, Biotechnology, and Biochemistry, v. 65, p. 254-263, 2001.

NAWROCKI, E. P.; KOLBE, D. L.; EDDY, S. R. INFERNAL 1.0: inference of RNA alignments. Bioinformatics, v. 25, p. 1335-1337, 2009.

NISHIGIMA, F. N.; WEBER, R. R.; BÍCEGO, M. C. Aliphatic and aromatic hydrocarbons in sediments of Santos and Cananéia, SP, Brazil. Marine Pollution Bulletin, v. 42, p. 10641072, 2001.

NOGALES, B.; MOORE, E. R. B.; LLOBET-BROSSA, E.; ROSSELLO-MORA, R.; AMANN, R.; TIMMIS, K. N. Combined use of 16S ribosomal DNA and 16S rRNA to study the bacterial community of polychlorinated biphenyl-polluted soil. Applied and Environmental Microbiology, v. 67, p. 1874-1884, 2001.

NOJIRI, H.; SHINTANI, M.; OMORI, T. Divergence of mobile genetic elements involved in the distribution of xenobiotic-catabolic capacity. Applied Microbiology and Biotechnology, v. 64, p. 154-174, 2004.

NOVAIS, R. C. THORSTENSON, Y. R. The evolution of pyrosequencing ${ }^{\circledR}$ for microbiology: from genes to genomes. Journal of Microbiological Methods, v. 86, p. 1-7, 2011. 
NYYSSÖNEN, M.; PISKONEN, R.; ITÄVAARA, M. A target real-time PCR assay for studying naphthalene degradation in the environment. Microbial Ecology, v. 52, p. 533-543, 2006.

OGUNSEITAN, A. The concept of microbial species. In: OGUNSEITAN, ADELE (Ed.). Microbial diversity: form and function in Prokaryotes. Malden: Blackwell Science Ltd, 2007. p. 3-21.

PAES, F. A. Análise de comunidades microbianas de solo de manguezal por T-RFLP e microarranjos de DNA. 2008. 95 f. Dissertação (Mestrado em Ciências Marinhas Tropicais) - Instituto de Ciências do Mar, Universidade Federal do Ceará, Fortaleza, 2008.

PANDEY, A.; SRIVASTAVA, N.; SINHA, P. Optimization of hydrogen production by Rhodobacter sphaeroides NMBL-01. Biomass \& Bioenergy, v. 37, p. 251-256, 2012.

PARALES, R. E. RESNICK, S. M. Aromatic ring hydroxylating dioxygenases. In: RAMOS, J.L.; LEVESQUE, R.C. (Ed.). Pseudomonas. Netherlands: Springer US, $2006 . \quad$ p. 287-340.

PARAMESWARAN, P.; JALILI, R.; TAO, L.; SHOKRALLA, S.; GHARIZADEH, B. A pyrosequencing-tailored nucleotide barcode design unveils opportunities for large-scale sample multiplexing. Nucleic Acids Research, v. 35, p. 2-9, 2007.

PAULA, F. S. Diversidade e estrutura funcional de comunidades microbianas em solos da Amazônia e resposta a mudanças na forma de uso do solo. 2012. $107 \mathrm{f}$. Tese (Doutorado em Microbiologia) - Instituto de Ciências Biomédicas, Universidade de São Paulo, São Paulo, 2012.

PEIRSON, S. N.; BUTLER, J. N.; FOSTER, R. G. Experimental validation of novel and conventional approaches to quantitative real-time PCR data analysis. Nucleic Acid Research, v. 31, p. 1-7, 2003.

PEIXOTO, R.; CHAER, G.; CARMO, F.; ARAÚJO, F.; PAES, J.; VOLPON, A.; SANTIAGO, G.; ROSADO, A. Bacterial communities reflect the spatial variation in pollutant levels in Brazilian mangrove sediment. Antonie van Leeuwenhoek, v. 99, p. 341-354, 2011.

PELLIZARI, V. H.; BEZBORODNIKOV, S.; QUENSEN , J. F.; TIEDJE, J. Evaluation of strains isolated by growth on naphthalene and biphenyl for hybridization of genes to dioxygense probes and polychlorinated biphenyl-degrading ability. Applied and Environmental Microbiology, v. 62, p. 2053-2058, 1996.

PENG, R.-H.; XIONG, A.-S.; XUE, Y.; FU, X.-Y.; GAO, F.; ZHAO, W.; TIAN, Y.-S.; YAO, Q.-H. Microbial biodegradation of polyaromatic hydrocarbons. FEMS Microbiology Reviews, v. 32, p. 927-55, 2008.

PENG, R.-H.; XIONG, A.-S.; XUE, Y.; FU, X.-Y.; GAO, F.; ZHAO, W.; TIAN, Y.-S.; YAO, Q.-H. A profile of ring-hydroxylating oxygenases that degrade aromatic pollutants. In: WHITACRE, D. M. M. (Ed.). Reviews of Environmental Contamination and Toxicology. Springer New York, 2010. v. 206. p. 65-94. 
PETROSINO, J. F.; HIGHLANDER, S.; LUNA, R. A.; GIBBS, R. A.; VERSALOVIC, J. Metagenomic pyrosequencing and microbial identification. Clinical Chemistry, v. 55, p. 856-866, 2009.

PIEPER, D. H. Aerobic degradation of polychlorinated biphenyls. Applied Microbiology and Biotechnology, v. 67, p. 170-191, 2005.

PIEPER, D. H. REINEKE, W. Engineering bacteria for bioremediation. Current Opinion in Biotechnology, v. 11, p. 262-270, 2000.

PINTO, R. F. O despejo de efluentes e a distribuição e densidade das populações bacterianas na Baía de Santos e Enseada do Guarujá (SP). 2003. 69 f. Dissertação (Mestrado em Oceanografia Biológica) - Instituto Oceanográfico, Universidade de São Paulo, São Paulo, 2003.

PIZZUL, L.; CASTILLO, M.; STENSTROM, J. Effect of rapeseed oil on the degradation of polycyclic aromatic hydrocarbons in soil by Rhodococcus wratislaviensis. International Biodeterioration Biodegradation, v. 59, p. 111-118, 2007.

PIZZUL, L.; PILAR CASTILLO, M.; STENSTRÖM, J. Characterization of selected actinomycetes degrading polyaromatic hydrocarbons in liquid culture and spiked soil. World Journal of Microbiology and Biotechnology, v. 22, p. 745-752, 2006.

PIZZUL, L.; SJÖGREN, Å.; CASTILLO, M. D.; STENSTRÖM, J. Degradation of polycyclic aromatic hydrocarbons in soil by a two-step sequential treatment. Biodegradation, v. 18, p. 607-616, 2007.

PORTER, S. L.; WILKINSON, D. A.; BYLES, E. D.; WADHAMS, G. H.; TAYLOR, S.; SAUNDERS, N. J.; ARMITAGE, J. P. Genome sequence of Rhodobacter sphaeroides strain WS8N. Journal of Bacteriology, v. 193, p. 4027-4028, 2011.

POSTHUMA, J. The composition of petroleum. Rapports et Proces-verbaux des Réunions, v. 171, p. 7-16, 1977.

POWELL, S. M.; FERGUSON, S. H.; BOWMAN, J. P.; SNAPE, I. Using real-time PCR to assess changes in the hydrocarbon-degrading microbial community in Antarctic soil during bioremediation. Microbial Ecology, v. 52, p. 523-532, 2006.

PRADA-GAMERO, R. M.; VIDAL-TORRADO, P.; FERREIRA, T. O. Mineralogia e físicoquímica dos solos de mangue do rio Iriri no canal de Bertioga (Santos, SP). Revista Brasileira de Ciência do Solo, v. 28, p. 233-243, 2004.

QIAO, L. WANG, J.-L. Microbial degradation of pyridine by Paracoccus sp. isolated from contaminated soil. Journal of Hazardous Materials, v. 176, p. 220-225, 2010.

R DEVELOPMENT CORE TEAM. R: a language and environment for statistical computing. Viena: R Foundation for Statistical Computing, 2010.

RACHID, B. R. F. Avaliação ecotoxicológica dos efluentes domésticos lançados pelos sistemas de disposição oceânica da Baixada Santista, SP. 2002. 286 f. Tese (Doutorado em 
Oceanografia Biológica) - Instituto Oceanográfico, Universidade de São Paulo, São Paulo, 2002.

RAMSAY, M. A.; SWANNELL, R. P. J.; SHIPTON, W. A.; DUKE, N. C.; HILL, R. T. Effect of bioremediation on the microbial community in oiled mangrove sediments. Marine Pollution Bulletin, v. 41, p. 413-419, 2000.

RAVOT, G.; MAGOT, M.; FARDEAU, M.-L.; PATEL, B. K. C.; THOMAS, P.; GARCIA, J.-L.; OLLIVIER, B. Fusibacter paucivorans gen. nov., sp. nov., an anaerobic, thiosulfatereducing bacterium from an oil-producing well. International Journal of Systematic Bacteriology, v. 49, p. 1141-1147, 1999.

RAWLINGS, D. E. KUSANO, T. Molecular genetics of Thiobacillus ferrooxidans. Microbiological Reviews, v. 58, p. 39-55, 1994.

REEF, R.; FELLER, I. C.; LOVELOCK, C. E. Nutrition of mangroves. Tree Physiology, v. 30, p. 1148-1160, 2010.

RENOSTO, F.; PATEL, H. C.; MARTIN, R. L.; THOMASSIAN, C.; ZIMMERMAN, G.; SEGEL, I. H. ATP sulfurylase from higher plants: kinetic and structural characterization of the chloroplast and cytosol enzymes from spinach leaf. Archives of Biochemistry and Biophysics, v. 307, p. 272-285, 1993.

REYES, L. F. Diversidade de bactérias em manguezal e biodegradação de hidrocarbonetos poliaromáticos. 2009. 126 f. Tese (Doutorado em Biotecnologia) Programa de Pós-Graduação Interunidades em Biotecnologia, Universidade de São Paulo, São Paulo, 2009.

RHEE , S.-K.; LIU, X.; WU, L.; CHONG, S. C.; WAN, X.; ZHOU, J. Detection of genes involved in biodegradation and biotransformation in microbial communities by using 50-Mer oligonucleotide microarrays. Applied and Environmental Microbiology, v. 70, p. 43034317, 2004.

RODRIGUES, D. F. Caracterização polifásica da diversidade de isolados degradadores de poluentes xenobióticos na Baixada Santista. 2002. 153 f. Dissertação (Mestrado em Microbiologia) - Universidade de São Paulo, São Paulo, 2002.

RODRIGUES, D. F.; SAKATA, S. K.; COMASSETO, J. V.; BÍCEGO, M. C.; PELLIZARI, V. H. Diversity of hydrocarbon-degrading Klebsiella strains isolated from hydrocarboncontaminated estuaries. Journal of Applied Microbiology, v. 106, p. 1304-1314, 2009.

RODRIGUES, J. L. M.; AIELLO, M. R.; URBANCE, J. W.; TSOI, T. V.; TIEDJE, J. M. Use of both 16S rRNA and engineered functional genes with real-time PCR to quantify an engineered, PCB-degrading Rhodococcus in soil. Journal of Microbiological Methods, v. 51, p. 181-189, 2002.

ROESCH, L. F. W.; FULTHORPE, R. R.; RIVA, A.; CASELLA, G.; HADWIN, A. K. M.; KENT, A. D.; DAROUB, S. H.; CAMARGO, F. A. O.; FARMERIE, W. G.; TRIPLETT, E. W. Pyrosequencing enumerates and contrasts soil microbial diversity. ISME Journal, v. 1, p. 283-290, 2007. 
ROJAS-AVELIZAPA, N. G.; CERVANTES-GONZALEZ, E.; CRUZ-CAMARILLO, R.; ROJAS-AVELIZAPA, L. I. Degradation of aromatic and asphaltenic fractions by Serratia liquefasciens and Bacillus sp. Bulletin of Environmental Contamination and Toxicology, v. 69, p. 835-842, 2002.

ROLING, W. F. M.; MILNER, M. G.; JONES, D. M.; LEE, K.; DANIEL, F.; SWANNELL, R. J. P.; HEAD, I. M. Robust hydrocarbon degradation and dynamics of bacterial communities during nutrient-enhanced oil spill bioremediation. Applied and Environmental Microbiology, v. 68, p. 5537-5548, 2002.

RONAGHI, M. Pyrosequencing sheds light on DNA sequencing. Genome Res, v. 11, p. 311, 2001.

RONAGHI, M. ELAHI, E. Pyrosequencing for microbial typing. Journal Of Chromatography B Analytical Technologies In The Biomedical And Life Sciences, v. 782, p. 67-72, 2002.

RONAGHI, M.; KARAMOHAMED, S.; PETTERSSON, B.; UHLEN, M.; NYREN, P. Realtime DNA sequencing using detection of pyrophosphate release. Analytical Biochemistry, v. 242, p. 84-89, 1996.

RONAGHI, M.; PETTERSSON, B.; UHLEN, M.; NYREN, P. PCR-introduced loop structure as primer in DNA sequencing. Biotechniques, v. 25, p. 876-880, 1998.

ROSS, G. The public health implications of polychlorinated biphenyls (PCBs) in the environment. Ecotoxicology and Environmental Safety, v. 59, p. 275-291, 2004.

ROSSELLÓ-MÓRA, R. Towards a taxonomy of Bacteria and Archaea based on interactive and cumulative data repositories. Environmental Microbiology, v. 14, p. 318-334, 2012.

ROSSELLÓ-MORA, R. AMANN, R. The species concept for prokaryotes. FEMS Microbiology Reviews, v. 25, p. 39-67, 2001.

SAKATA, S.; TANIGUCHI, S.; RODRIGUES, D.; URANO, M.; WADERMUREN, M.; PELLIZARI, V. H.; COMASSETO, J. Development of a static headspace gas chromatographic/mass spectrometric method to analyze the level of volatile contaminants bioegradation. Jorunal of Chromatography, p. 67-71, 2004.

SANGER, F. COULSON, A. R. The use of thin acrylamide gels for DNA sequencing. FEBS Letters, v. 87, p. 107-110, 1978.

SANGER, F.; NICKLEN, S.; COULSON, A. R. DNA sequencing with chain-terminating inhibitors. Biotechnology, v. 24, p. 104-108, 1977.

SANTOS, H. F.; CARMO, F. L.; PAES, J. E. S.; ROSADO, A. S.; PEIXOTO, R. S. Bioremediation of mangroves impacted by petroleum. Water Air Soil Pollution, v. 216, p. 329-350, 2011a. 
SANTOS, H. F.; CURY, J. C.; DO CARMO, F. L.; DOS SANTOS, A. L.; TIEDJE, J. M.; VAN ELSAS, J. D.; ROSADO, A. S.; PEIXOTO, R. S. Mangrove bacterial diversity and the impact of oil contamination revealed by pyrosequencing: bacterial proxies for oil pollution. PLoS One, v. 6, p. e16943, 2011b.

SCHAEFFER-NOVELLI, Y. Brazilian mangroves. Aquatic Ecosystem Health and Management, v. 3, p. 561-570, 2000.

SCHAEFFER-NOVELLI, Y.; CINTRÓN-MOLERO, G.; ADAIME, R. R.; DE CAMARGO, T. M. Variability of mangrove ecosystems along the Brazilian coast. Estuaries, v. 13, p. 204218, 1990a.

SCHAEFFER-NOVELLI, Y.; MESQUITA, H. S. L.; CINTRÓN-MOLERO, G. The Cananéia lagon estuarine system, São Paulo, Brasil. Estuaries, v. 13, p. 193-203, 1990 b.

SCHENA, M.; SHALON, D.; DAVIS, R. W.; BROWN, P. O. Quantitative monitoring of gene expression patterns with a complementary DNA microarray. Science, v. 270, p. 467470, 1995.

SCHIPPERS, A.; BOSECKER, K.; SPRÖER, C.; SCHUMANN, P. Microbacterium oleivorans sp. nov. and Microbacterium hydrocarbonoxydans sp. nov., novel crude-oildegrading Gram-positive bacteria. International Journal of Systematic and Evolutionary Microbiology, v. 55, p. 655-660, 2005.

SCHLEIFER, K. H. Classification of Bacteria and Archaea: past, present and future. Systematic and Applied Microbiology, v. 32, p. 533-542, 2009.

SCHLOSS, P. HANDELSMAN, J. A statistical toolbox for metagenomics: assessing functional diversity in microbial communities. BMC Bioinformatics, v. 9, p. 34, 2008.

SCHLOSS, P. D. HANDELSMAN, J. Introducing DOTUR, a computer program for defining operational taxonomic units and estimating species richness. Applied and Environmental Microbiology, v. 71, p. 1501-1506, 2005.

SCHLOSS, P. D. HANDELSMAN, J. Toward a census of Bacteria in soil. PLoS Computational Biology, v. 2, p. e92, 2006.

SCHLOSS, P. D.; WESTCOTT, S. L.; RYABIN, T.; HALL, J. R.; HARTMANN, M.; HOLLISTER, E. B.; LESNIEWSKI, R. A.; OAKLEY, B. B.; PARKS, D. H.; ROBINSON, C. J.; SAHL, J. W.; STRES, B.; THALLINGER, G. G.; VAN HORN, D. J.; WEBER, C. F. Introducing mothur: open-source, platform-Independent, community-supported software for describing and comparing microbial communities. Applied and Environmental Microbiology, v. 75, p. 7537-7541, 2009.

SCHWARTZ, P. M.; JACOBSON, S. W.; FEIN, G.; JACOBSON, J. L.; PRICE, H. A. LakeMichigan fish consumption as a source of polychlorinated-biphenyls in human cord serum, maternal serum, and milk. American Journal of Public Health, v. 73, p. 293-296, 1983.

SCULLION, J. Remediating polluted soils. Die Naturwissenschaften, v. 93, p. 51-65, 2006. 
SEGEL, I. H.; RENOSTO, F.; SEUBERT, P. A. Sulfate-activating enzymes. In: JAKOBY, W. B. ; GRIFFITH, O. W. (Ed.). Methods in Enzymology. Academic Press, 1987. v. 143. p. 334-349.

SEMPLE, K. T.; MORRISS, A. W. J.; PATON, G. I. Bioavailability of hydrophobic organic contaminants in soils: fundamental concepts and techniques for analysis. European Journal of Soil Science, v. 54, p. 809-818, 2003.

SEO, J.-S.; KEUM, Y.-S.; LI, Q. X. Bacterial degradation of aromatic compounds. International Journal of Environmental Research and Public Health, v. 6, p. 278-309, 2009.

SHELEPCHIKOV, A.; BRODSKII, E.; FESHIN, D.; ZHIL'NIKOV, V.; MIR-KADYROVA, E.; BALASHOVA, S. Polychlorinated dibenzo-p-dioxins, dibenzofurans, and biphenyls in soils of Moscow. Eurasian Soil Science, v. 44, p. 286-296, 2011.

SHIMURA, M.; MUKERJEE-DHAR, G.; KIMBARA, K.; NAGATO, H.; KIYOHARA, H.; HATTA, T. Isolation and characterization of a thermophilic Bacillus sp. JF8 capable of degrading polychlorinated biphenyls and naphthalene. FEMS Microbiology Letters, v. 178, p. 87-93, 1999.

SIDDAVATTAM, D.; KAREGOUDAR, T. B.; MUDDE, S. K.; KUMAR, N.; BADDAM, R.; AVASTHI, T. S.; AHMED, N. Genome of a novel isolate of paracoccus denitrificans capable of degrading N,N-dimethylformamide. Journal of Bacteriology, v. 193, p. 55985599, 2011.

SIIKAMÄKI, J.; SANCHIRICO, J. N.; JARDINE, S. L. Global economic potential for reducing carbon dioxide emissions from mangrove loss. Proceedings of the National Academy of Sciences, v. 109, p. 14369-14374, 2012.

SILVA, M. G. G. Diversidade funcional em solos de Terra Preta de Índio da Amazônia e carvão pirogênico. 2011. $188 \mathrm{f}$. Tese (Doutorado em Biologia na Agricultura e no Ambiente) - Centro de Energia Nuclear da Agricultura, Universidade de São Paulo, Piracicaba, 2011.

SINGH, B. K.; MUNRO, S.; REID, E.; ORD, B.; POTTS, J. M.; PATERSON, E.; MILLARD, P. Investigating microbial community structure in soils by physiological, biochemical and molecular fingerprinting methods. European Journal of Soil Science, v. 57, p. 72-82, 2006.

SINGH, B. K.; WALKER, A.; MORGAN, J. A. W.; WRIGHT, D. J. Biodegradation of chlorpyrifos by Enterobacter strain B-14 and Its use in bioremediation of contaminated soils. Applied and Environmental Microbiology, v. 70, p. 4855-4863, 2004.

SIQUEIRA, J. F.; SAKAMOTO, M.; ROSADO, A. S. Microbial community profiling using terminal restriction fragment length polymorphism (T-RFLP) and denaturing gradient gel electrophoresis (DGGE). Methods in Molecular Biology, v. 666, p. 71-85, 2010.

SISINNO, C. L. S.; PEREIRA NETTO, A. D.; REGO, E. C. P. D.; LIMA, G. D. S. V. Polycyclic aromatic hydrocarbons in industrial solid waste: a preliminary evaluation of the 
potential risk of environmental and human contamination in waste disposal areas. Cadernos de Saúde Pública, v. 19, p. 671-676, 2003.

SOCLO, H. H.; GARRIGUES, P.; EWALD, M. Origin of polycyclic aromatic hydrocarbons (PAHs) in coastal marine sediments: case studies in cotonou (Benin) and aquitaine (France) areas. Marine Pollution Bulletin, v. 40, p. 387-396, 2000.

SPAIN, A. M.; PEACOCK, A. D.; ISTOK, J. D.; ELSHAHED, M. S.; NAJAR, F. Z.; ROE, B. A.; WHITE, D. C.; KRUMHOLZ, L. R. Identification and Isolation of a Castellaniella species important during biostimulation of an acidic nitrate- and uranium-contaminated aquifer. Applied and Environmental Microbiology, v. 73, p. 4892-4904, 2007.

SPRINGAEL, D. TOP, E. M. Horizontal gene transfer and microbial adaptation to xenobiotics: new types of mobile genetic elements and lessons from ecological studies. Trends in Microbiology, v. 12, p. 53-58, 2004.

STULTS, J. R.; SNOEYENBOS-WEST, O.; METHE, B.; LOVLEY, D. R.; CHANDLER, D. P. Application of the 5 fluorogenic exonuclease assay (TaqMan) for quantitative ribosomal DNA and rRNA analysis in sediments. Applied and Environmental Microbiology, v. 67, p. 2781-2789, 2001.

SUENAGA, H.; GOTO, M.; FURUKAWA, K. Emergence of multifuncional oxigenase by random priming recombination. Journal of Bacteriology, v. 276, p. 2250-2256, 2001.

SUENAGA, H.; WATANABE, T.; SATO, M.; NGADIMAN, F.; FURUKAWA, K. Alteratiion of region specificity in biphenyl dioxigenase by active engineering. Journal of Bacteriology, v. 184, p. 3682-3688, 2002.

SUL, W. J.; COLE, J. R.; JESUS, E. D. C.; WANG, Q.; FARRIS, R. J.; FISH, J. A.; TIEDJE, J. M. Bacterial community comparisons by taxonomy-supervised analysis independent of sequence alignment and clustering. Proceedings of the National Academy of Sciences, v. 108, p. 14637-14642, 2011.

TAKETANI, R. G.; DOS SANTOS, H. F.; VAN ELSAS, J. D.; ROSADO, A. S. Characterisation of the effect of a simulated hydrocarbon spill on diazotrophs in mangrove sediment mesocosm. Antonie van Leeuwenhoek, v. 96, p. 343-354, 2009.

TAKETANI, R. G.; FRANCO, N. O.; ROSADO, A. S.; VAN ELSAS, J. D. Microbial community response to a simulated hydrocarbon spill in mangrove sediments. Journal of Microbiology Seoul Korea, v. 48, p. 7-15, 2010a.

TAKETANI, R. G.; YOSHIURA, C. A.; DIAS, A. C.; ANDREOTE, F. D.; TSAI, S. M. Diversity and identification of methanogenic archaea and sulphate-reducing bacteria in sediments from a pristine tropical mangrove. Antonie van Leeuwenhoek, v. 97, p. 401-411, 2010b.

TAM, N. F.; KE, L.; WANG, X. H.; WONG, Y. S. Contamination of polycyclic aromatic hydrocarbons in surface sediments of mangrove swamps. Environmental Pollution, v. 114, p. 255-263, 2001. 
TAM, N. F. Y.; GUO, C. L.; YAU, W. Y.; WONG, Y. S. Preliminary study on biodegradation of phenanthrene by bacteria isolated from mangrove sediments in Hong Kong. Marine Pollution Bulletin, v. 45, p. 316-324, 2002.

TAM, N. F. Y.; WONG, T. W. Y.; WONG, Y. S. A case study on fuel oil contamination in a mangrove swamp in Hong Kong. Marine Pollution Bulletin, v. 51, p. 1092-1100, 2005.

TAMURA, K.; DUDLEY, J.; NEI, M.; KUMAR, S. MEGA4: molecular evolutionary genetics analysis - Software Version 4.0. Molecular Biology and Evolution, v. 24, p. 15961599, 2007.

TAMURA, K.; PETERSON, D.; PETERSON, N.; STECHER, G.; NEI, M.; KUMAR, S. MEGA5: molecular evolutionary genetics analysis using maximum likelihood, evolutionary distance, and maximum parsimony methods. Molecular Biology and Evolution, 2011.

TEIXEIRA, L. C. R. S.; PEIXOTO, R. S.; CURY, J. C.; SUL, W. J.; PELLIZARI, V. H.; TIEDJE, J.; ROSADO, A. S. Bacterial diversity in rhizosphere soil from Antarctic vascular plants of Admiralty Bay, maritime Antarctica. The ISME Journal, v. 4, p. 989-1001, 2010.

TIAN, Y.; LUO, Y.-R.; ZHENG, T.-L.; CAI, L.-Z.; CAO, X.-X.; YAN, C.-L. Contamination and potential biodegradation of polycyclic aromatic hydrocarbons in mangrove sediments of Xiamen, China. Marine Pollution Bulletin, v. 56, p. 1184-1191, 2008.

TILLMANN, S.; STROMPL, C.; TIMMIS, K. N.; ABRAHAM, W. R. Stable isotope probing reveals the dominant role of Burkholderia species in aerobic degradation of PCBs. FEMS Microbioly Ecology, v. 52, p. 207-217, 2005.

TIQUIA, S. M.; WU, L.; CHONG, S. C.; PASSOVETS, S.; XU, D.; XU, Y.; ZHOU, J. Evaluation of 50-mer oligonucleotide arrays for detecting microbial populations in environmental samples. Biotechniques, v. 36, p. 664-675, 2004.

TOLEDO, F. L.; GONZALEZ-LOPEZ, J.; CALVO, C. Production of bioemulsifier by Bacillus subtilis, Alcaligenes faecalis and Enterobacter species in liquid culture. Bioresource Technology, v. 99, p. 8470-8475, 2008.

TOURNA, M.; FREITAG, T. E.; PROSSER, J. I. Stable isotope probing analysis of interactions between ammonia oxidizers. Applied and Environmental Microbiology, v. 76, p. 2468-77, 2010.

TRAVERSO-CORI, A.; CHAIMOVICH, H.; CORI, O. Kinetic studies and properties of potato apyrase. Archives of Biochemistry and Biophysics, v. 109, p. 173-184, 1965.

UHLIK, O.; JECNA, K.; MACKOVA, M.; VLCEK, C.; HROUDOVA, M.; DEMNEROVA, K.; PACES, V.; MACEK, T. Biphenyl-metabolizing bacteria in the rhizosphere of horseradish and bulk soil contaminated by polychlorinated biphenyls as revealed by stable isotope probing. Applied and Environmental Microbiology, v. 75, p. 6471-6477, 2009.

VALASEK, M. A. REPA, J. J. The power of real-time PCR. Advances in Physiology Education, v. 29, p. 151-159, 2005. 
VAN HAMME, J. D.; SINGH, A.; WARD, O. P. Recent advances in petroleum microbiology. Microbiology and Molecular Biology Reviews, v. 67, p. 503-549, 2003.

VAN NOSTRAND, J. D.; GENTRY, T. J.; ZHOU, J. Microarray-based microbial identification and characterization In: TANG, Y.W.; STRATTON, C.W. (Ed.). Advanced Techniques in Diagnostic Microbiology. New York, NY: Springer US, 2012. p. 276-290.

VAN RAIJ, B.; CANTARELLA, H.; ANDRADE, J. C.; QUAGGIO, J. A. Análise química para avaliação da fertilidade de solos tropicais: Secondary Análise química para avaliação da fertilidade de solos tropicais. Campinas: Instituto Agronômico, 2001. 285 p.

VENTURA, M.; CANCHAYA, C.; TAUCH, A.; CHANDRA, G.; FITZGERALD, G. F.; CHATER, K. F.; VAN SINDEREN, D. Genomics of Actinobacteria: tracing the evolutionary history of an ancient phylum. Microbiology and Molecular Biology Reviews, v. 71, p. 495548, 2007.

VIVIANI, V. R. The origin, diversity, and structure function relationships of insect luciferases. Cellular and Molecular Life Sciences, v. 59, p. 1833-1850, 2002.

VOLKOVA, V. P. SINYAK, K. M. On the Possibility of Germination of Bacilli and Clostridia Spores in Soil. Izvestiya Akademii Nauk Sssr Seriya Biologicheskaya, p. 791795, 1989.

WALKER, N. J. A technique whose time has come. Science, v. 296, p. 557-559, 2002.

WATANABE, K.; FUTAMATA, H.; HARAYAMA, S. Understanding the diversity in catabolic potential of microorganisms for the development of bioremediation strategies. Antonie van Leeuwenhoek, v. 81, p. 655-663, 2002.

WEELINK, S. A. B.; VAN DOESBURG, W.; SAIA, F. T.; RIJPSTRA, W. I. C.; RÖLING, W. F. M.; SMIDT, H.; STAMS, A. J. M. A strictly anaerobic betaproteobacterium Georgfuchsia toluolica gen. nov., sp. nov. degrades aromatic compounds with Fe(III), Mn(IV) or nitrate as an electron acceptor. FEMS Microbiology Ecology, v. 70, p. 575-585, 2009.

WEIDERPASS, E.; ADAMI, H. O.; BARON, J. A.; WICKLUND-GLYNN, A.; AUNE, M.; ATUMA, S.; PERSSON, I. Organochlorines and endometrial cancer risk. Cancer Epidemiology Biomarkers \& Prevention, v. 9, p. 487-493, 2000.

WERLEN, C.; KOHLER, H. P. E.; VAN DER MEER, J. R. The broad substrate chlorobenzene dioxygenase and cis-chlorobenzene dihydrodiol dehydrogenase of Pseudomonas sp. strain p51 are linked evolutionarily to the enzumes for benzene and toluene degradation. The Journal of Biological Chemistry, v. 271, p. 4009-4016, 1996.

WHYTE, L. G.; SCHULTZ, A.; VAN BEILEN, J. B.; LUZ, A. P.; PELLIZARI, V.; LABBÉ, D.; GREER, C. W. Prevalence of alkane monooxygenase genes in Arctic and Antarctic hydrocarbon-contaminated and pristine soils1. FEMS Microbiology Ecology, v. 41, p. 141150, 2002.

WIDDEL, F. RABUS, R. Anaerobic biodegradation of saturated and aromatic hydrocarbons. Current Opinion in Biotechnology, v. 12, p. 259-276, 2001. 
WIEGEL, J. WU, Q. Microbial reductive dehalogenation of polychlorinated biphenyls. FEMS Microbiology Ecology, v. 32, p. 1-15, 2000.

WILSON, K. Preparation of genomic DNA from bacteria. In: AUSUBEL, F.M. (Ed.). Current protocols in molecular biology. Massachusetts: John Wiley \& Sons, Inc., 2001. p. 241-245.

WINDERL, C.; PENNING, H.; NETZER, F. V.; MECKENSTOCK, R. U.; LUEDERS, T. DNA-SIP identifies sulfate-reducing Clostridia as important toluene degraders in tar-oilcontaminated aquifer sediment. ISME Journal, v. 4, p. 1314-1325, 2010.

WITZIG, R.; JUNCA, H.; PIEPER, D. H. Assessment of toluene / biphenyl dioxygenase gene diversity in benzene-polluted soils: links between benzene biodegradation and genes similar to those encoding isopropylbenzene Dioxygenases. Applied and Environmental Microbiology, v. 72, p. 3504-3514, 2006.

WONGSA, P.; TANAKA, M.; UENO, A.; HASANUZZAMAN, M.; YUMOTO, I.; OKUYAMA, H. Isolation and characterization of novel strains of Pseudomonas aeruginosa and Serratia marcescens possessing high efficiency to degrade gasoline, kerosene, diesel oil, and lubricating oil. Current Microbiology, v. 49, p. 415-422, 2004.

WU, L.; LIU, X.; SCHADT, C. W.; ZHOU, J. Microarray-based analysis of subnanogram quantities of microbial community DNAs by using whole-community genome amplification. Applied and Environmental Microbiology, v. 72, p. 4931-4941, 2006.

WU , L.; LIU, X.; SCHADT, C. W.; ZHOU, J. Microarray-Based Analysis of Subnanogram Quantities of Microbial Community DNAs by Using Whole-Community Genome Amplification. Applied and Environmental Microbiology, v. 72, p. 4931-4941, 2006.

WU, Y.-L.; LIN, L.-F.; SHIH, S.-I.; YU, K.-M.; HSIEH, L.-T.; WANG, L.-C.; CHANGCHIEN, G.-P. Atmospheric deposition of polychlorinated dibenzo-p-dioxins and dibenzofurans on the soils in the vicinity of municipal solid waste incinerators. Journal of Environmental Science and Health, v. 44, p. 1327-1334, 2009.

WU, Y.; HE, T.; ZHONG, M.; ZHANG, Y.; LI, E.; HUANG, T.; HU, Z. Isolation of marine benzo[a]pyrene-degrading Ochrobactrum sp. BAP5 and proteins characterization. Journal of Environmental Sciences, v. 21, p. 1446-1451, 2009.

YÁÑEZ, M. A.; CARRASCO-SERRANO, C.; BARBERÁ, V. M.; CATALÁN, V. Quantitative detection of Legionella pneumophila in water samples by immunomagnetic purification and real-time PCR amplification of the dotA gene. Applied and Environmental Microbiology, v. 71, p. 3433-3441, 2005.

YANG, C.-Y.; YU, M.-L.; GUO, H.-R.; LAI, T.-J.; HSU, C.-C.; LAMBERT, G.; GUO, Y. L. The endocrine and reproductive function of the female Yucheng adolescents prenatally exposed to PCBs/PCDFs. Chemosphere, v. 61, p. 355-360, 2005.

YANG, G.-P. Polycyclic aromatic hydrocarbons in the sediments of the South China Sea. Environmental Pollution, v. 108, p. 163-171, 2000. 
YAO, H.; REN, Y.; DENG, X.; WEI, C. Dual substrates biodegradation kinetics of m-cresol and pyridine by Lysinibacillus cresolivorans. Journal of Hazardous Materials, v. 186, p. 1136-1140, 2011.

YAO, Y.; TAKASUGA, T.; MASUNAGA, S.; NAKANISHI, J. Detailed study on the levels of polychlorinated dibenzo-p-dioxins, polychlorinated dibenzofurans and polychlorinated biphenyls in Yusho rice oil. Chemosphere, v. 46, p. 1461-1469, 2002.

YATES, C.; HOLMES, A. J.; GILLINGS, M. R. Novel forms of ring-hydroxylating dioxygenases are widespread in pristine and contaminated soils. Environmental Microbiology, v. 2, p. 644-653, 2000.

YENDER, R.; MICHAEL, J.; LORD, C. Managing seafood safety after an oil spill: Secondary Managing seafood safety after an oil spill. Seattle: National Oceanic and Atmospheric Administration NOAA, 2002. 72 p.

YU, H. Environmental carcinogenic polycyclic aromatic hydrocarbons: photochemistry and phototoxicity. Journal of Environmental Science and Health, v. 20, p. 149-183, 2002.

ZENG, Y.; HONG, P. K. A.; WAVREK, D. A. Integrated chemical-biological treatment of benzo[a]pyrene. Environmental Science \& Technology, v. 34, p. 854-862, 2000.

ZHANG, B.; MENG, F.; SHI, C.; YANG, F.; WEN, D.; ARONSSON, J.; GBOR, P. K.; SLOAN, J. J. Modeling the atmospheric transport and deposition of polychlorinated dibenzop-dioxins and dibenzofurans in North America. Atmospheric Environment, v. 43, p. 22042212, 2009.

ZHANG, J.; CAI, L.; YUAN, D.; CHEN, M. Distribution and sources of polynuclear aromatic hydrocarbons in Mangrove surficial sediments of Deep Bay, China. Marine Pollution Bulletin, v. 49, p. 479-486, 2004.

ZHANG, T. FANG, H. H. P. Applications of real-time polymerase chain reaction for quantification of microorganisms in environmental samples. Applied and Environmental Microbiology, v. 70, p. 281-289, 2006.

ZHANG, Y.; DONG, J.; YANG, Z.; ZHANG, S.; WANG, Y. Phylogenetic diversity of nitrogen-fixing bacteria in mangrove sediments assessed by PCR-denaturing gradient gel electrophoresis. Archives of Microbiology, v. 190, p. 19-28, 2008.

ZHANG, Y.; ZHANG, X.; LIU, X.; XIAO, Y.; QU, L.; WU, L.; ZHOU, J. Microarray-based analysis of changes in diversity of microbial genes involved in organic carbon decomposition following land use/cover changes. FEMS Microbiology Letters, v. 266, p. 144-51, 2007.

ZHOU, H. W.; WONG, A. H. Y.; YU, R. M. K.; PARK, Y. D.; WONG, Y. S.; TAM, N. F. Y. Polycyclic aromatic hydrocarbon-induced structural shift of bacterial communities in mangrove sediment. Microbial Ecology, v. 58, p. 153-160, 2009.

ZHOU, J. Microarrays for bacterial detection and microbial community analysis. Current Opinion in Microbiology, v. 6, p. 288-294, 2003. 
ZIELINSKI, M.; BACKHAUS, S.; HOFER, B. The principal determinants for the structure of the substrate-binding pocket are located within a central core of a biphenyl dioxygenase $\alpha$ subunit. Microbiology, v. 148, p. 2439-2448, 2002.

ZIEMBIŃSKA, A.; CIESIELSKI, S.; MIKSCH, K. Ammonia oxidizing bacteria community in activated sludge monitored by denaturing gradient gel electrophoresis (DGGE). The Journal of General and Applied Microbiology, v. 55, p. 373-380, 2009.

ZOPFI, J.; FERDELMAN, T. G.; JØRGENSEN, B. B.; TESKE, A.; THAMDRUP, B. Influence of water column dynamics on sulfide oxidation and other major biogeochemical processes in the chemocline of Mariager Fjord (Denmark). Marine Chemistry, v. 74, p. 2951, 2001. 